UNIVERSIDADE DE SÃO PAULO

FACULDADE DE EDUCAÇÃO

CYNTHIA LUSHIUEN SHIEH

O que ensinar nas diferentes escolas públicas primárias paulistas: um estudo sobre os programas de ensino (1887-1929)

São Paulo

2010 
CYNTHIA LUSHIUEN SHIEH

\title{
O que ensinar nas diferentes escolas públicas primárias paulistas: um estudo sobre os programas de ensino (1887-1929)
}

\author{
Dissertação de mestrado apresentada \\ à Faculdade de Educação da Universidade de \\ São Paulo como exigência parcial para a \\ obtenção do título de mestre
}

Área de Concentração: História da Educação e Historiografia Orientadora: Profa. Dra. Dislane Zerbinatti Moraes 
Autorizo a reprodução e divulgação total ou parcial deste trabalho, por qualquer meio convencional ou eletrônico, para fins de estudo e pesquisa, desde que citada a fonte

Catalogação na Publicação

Serviço de Biblioteca e Documentação

Faculdade de Educação da Universidade de São Paulo

\section{7(81.61) Shieh, Cynthia Lushiuen}

S555q O que ensinar nas diferentes escolas públicas primárias paulistas: um estudo sobre os programas de ensino (1887-1929) / Cynthia Lushiuen Shieh ; orientação Dislane Zerbinatti Moraes. São Paulo : s.n., 2010.

183 p. : il., tabs. + 1 CDRom.

Dissertação (Mestrado - Programa de Pós-Graduação em Educação. Área de Concentração: História da Educação e Historiografia) - - Faculdade de Educação da Universidade de São Paulo.

1. História da educação - São Paulo - 1887-1929 2. Escola pública 3. Saberes escolares 4. Cultura escolar I. Moraes, Dislane Zerbinatti, orient. 


\section{FOLHA DE APROVAÇÃO}

\section{Cynthia Lushiuen Shieh}

O que ensinar nas diferentes escolas públicas primárias paulistas: um estudo sobre os programas de ensino (1887-1929)

Dissertação de mestrado apresentada à Faculdade de Educação da Universidade de São

Paulo como exigência parcial para a obtenção do título de mestre

Aprovado em:

Banca examinadora

Prof. Dr.

Julgamento:

Prof. Dr.

Julgamento:

Prof. Dr.

Julgamento:
Instituição:

Assinatura:

Instituição:

Assinatura:

Instituição:

Assinatura: 
Aos meus queridos avós 


\section{AGRADECIMENTOS}

À Dislane Zerbinatti Moraes, pelo incentivo, generosidade, paciência e orientação segura

À Rita de Cassia Gallego, pela ajuda e apoio inestimáveis com os quais eu conto desde a elaboração do projeto de pesquisa até o momento

À Rosa Fátima de Souza, pela leitura cuidadosa do meu relatório de qualificação, que resultou em preciosas sugestões

À Denice Barbara Catani, por ter me introduzido no caminho da pesquisa em História da Educação, através da Iniciação Científica

Aos funcionários do Arquivo Público do Estado e aos da Biblioteca da Faculdade de Educação da Universidade de São Paulo, pela atenção com que sempre me receberam

À Maria Ivanildes Batista e à Arlene Moreira da Silva, bibliotecárias do Instituto Sud Mennucci (Centro do Professorado Paulista), pela gentileza e simpatia com que me acolhiam

Aos colegas professores do Centro de Educação Infantil Pinheiros e aos seus demais funcionários, por colaborarem nos dias nos quais não pude comparecer

Aos amigos Maria José Abrão, Arlete dos Santos Oliveira, Fernando Henrique Tisque dos Santos e Patrícia Aparecida do Amparo, pelas conversas nas quais compartilhamos nossas experiências no curso de pós-graduação

Aos meus pais, Shieh e Irene, aos meus irmãos, Leonardo e Kathia, e ao restante da minha família, pelo apoio e por compreenderem minha ausência em tantas ocasiões 
Quem construiu Tebas, a das sete portas?

Nos livros vem o nome dos reis, Mas foram os reis que transportaram as pedras?

Babilonia, tantas vezes destruída,

Quem outras tantas a reconstruiu? Em que casas

Da Lima Dourada moravam seus obreiros?

No dia em que ficou pronta a Muralha da China para onde

Foram os seus pedreiros? A grande Roma

Está cheia de arcos de triunfo. Quem os ergueu? Sobre quem

Triunfaram os Césares? A tão cantada Bizâncio

Só tinha palácios

Para os seus habitantes? Até a legendária Atlântida

Na noite em que o mar a engoliu

Viu afogados gritar por seus escravos.

Ojovem Alexandre conquistou as Índias

Sozinho?

César venceu os gauleses.

Nem sequer tinha um cozinheiro ao seu serviço? Quando a sua armada se afundou Filipe de Espanha

Chorou. E ninguém mais?

Frederico II ganhou a guerra dos sete anos Quem mais a ganhou?

Em cada página uma vitória. Quem cozinhava os festins? Em cada década um grande homem. Quem pagava as despesas?

Tantas histórias Quantas perguntas

(“Perguntas de um operário que lê”, de Bertol Brecht) 


\section{RESUMO}

SHIEH, Cynthia Lushiuen. O que ensinar nas diferentes escolas públicas primárias paulistas: um estudo sobre os programas de ensino (1887-1929). Dissertação (mestrado). Faculdade de Educação, Universidade de São Paulo, São Paulo, 2010.

O estudo aqui apresentado insere-se na linha de pesquisa "História da Educação e Historiografia”. Trata-se da análise dos programas de ensino produzidos entre 1887 e 1929 no Estado de São Paulo, identificando os saberes escolares (matérias e conteúdos) escolhidos para serem ensinados nos seguintes tipos de escolas públicas primárias existentes no período: as escolas isoladas, as escolas-modelo, os grupos escolares, as escolas-modelo isoladas e as escolas reunidas. Para cada uma dessas modalidades de escolas, havia um programa de ensino específico a ser cumprido, significando, portanto, que as crianças que as freqüentavam não tinham a oportunidade de acesso aos mesmos saberes escolares. A partir do exame dos programas de ensino - os quais eram incorporados na legislação escolar ou publicados sob a forma de anexos na mesma - buscou-se atentar para aspectos como a permanência, o acréscimo e/ou a exclusão de determinados saberes escolares, além do modo como esses eram apresentados, isto é, se eram apenas descritas as matérias que deviam ser ensinadas ou se eram também detalhados os conteúdos de cada uma delas. Com isso, foi possível concluir que as finalidades principais das escolas primárias eram a nacionalização e a moralização dos alunos, embora, no caso das escolas isoladas, aquelas não tenham sido seus focos iniciais. Outro objetivo da pesquisa foi procurar referências à questão dos programas de ensino feitas por diversos profissionais da educação ao longo do período. Para isso, foram investigados relatórios de professores, de diretores de escolas-modelo e de grupos escolares (encontrados sob a forma de manuscritos), bem como de inspetores escolares. Nesse caso, eles também consistem em manuscritos, mas posteriormente passaram a ser incluídos nos Anuários do Ensino do Estado de São Paulo (1907-1926). Além disso, foram estudados textos de três periódicos educacionais paulistas cujos colaboradores, geralmente, ocupavam posições de destaque na hierarquia do sistema público de ensino do Estado de São Paulo (professores e exalunos da Escola Normal, diretores de escolas, entre outros): Revista de Ensino (1902-1918), Revista Escolar (1925-1927) e Educação (1927-1929). O recurso aos relatórios de ensino e às publicações pedagógicas permitiu entrever, especialmente, a participação ativa dos diversos sujeitos escolares no tocante ao debate em torno do que ensinar nas escolas primárias. Como fundamentação teórica, os principais autores utilizados foram André Chervel e Dominique Julia, que propõem a história das disciplinas escolares como meio de desvendar a cultura escolar, além de Ivor Goodson, um dos expoentes da história do currículo.

Palavras-chave: história da escola primária paulista - cultura escolar - saberes escolares legislação escolar - relatórios de ensino - periódicos educacionais. 


\begin{abstract}
SHIEH, Cynthia Lushiuen. What to teach in the different São Paulo's public primary schools: a study about course studies (1887-1929). Thesis (master). Faculdade de Educação, Universidade de São Paulo, São Paulo, 2010.
\end{abstract}

This study is included in the field of "Education History and Historiography". It is an analysis about the courses of studies elaborated between 1887 and 1929 in São Paulo, identifying the school knowledge (subjects and contents) selected to be teached in the following types of public primary schools existed in the period: isolated schools, model schools, graded schools, isolated model schools and reunited schools. For each model of school, there was a specific course of studies to be complied, meaning, thus, that the children that they attended couldn't have access to the same school knowledge. Through the investigation of the course of studies - that were incorporated in school legislation or attached in it - it aimed to pay attention to aspects as stability, addiction, and/or exclusion of certain school knowledge, besides the way that they were presented, it means, if only they described the subjects to be teached or if they detailed the contents of each one. This way, it was possible to conclude that the main goals of the primary schools were the nationalization and the moralization of the students. However, in case of isolated schools, those weren't the initial focus. Other intent of this research was look for references about the issue of course of studies made by different educational professionals during the period. For this objective, it were analyzed teacher's, principal's of model schools and graded schools (they are found as manuscripts) and inspector's reports. In this case, they also can be found as manuscripts, but later they were included in the Anuários do Ensino do Estado de São Paulo (1907-1926). Besides, it were investigated texts published in three educational magazines which authors, generally, kept high positions in the hierarchy of São Paulo's public educational system (teachers and old students of Normal School, principals of schools, and others): Revista de Ensino (1902-1918), Revista Escolar (1925-1927) and Educação (1927-1929). Through the utilization of the educational reports and the educational magazines it was able to note the active participation of the different educational professionals involving discussion about what to teach in primary schools. As theoretical standpoint, the main authors that have been used were André Chervel and Dominique Julia, who suggest the history of school subjects as a way to discover the school culture, and Ivor Goodson, one of the exponents of the history of curriculum.

Key-words: history of the public primary school - scholar culture - school knowledge - school legislation - educational reports - educational magazines. 


\section{LISTA DE TABELAS}

Tabela 1 - Número de estrangeiros que entraram no Estado de São Paulo, segundo a nacionalidade (1885-1929)

Tabela 2 - Crescimento demográfico da cidade de São Paulo............................................................. 35

Tabela 3 - Número de grupos escolares na Capital e no interior (1898-1927)................................... 58

Tabela 4 - Número de matrículas, por sexo, nos grupos escolares de todo o Estado $(1898-1916)$

Tabela 5 - Nacionalidade das crianças matriculadas nos grupos escolares de todo o Estado. 61

Tabela 6 - Proporção de alunos brasileiros e estrangeiros nos grupos escolares de todo o Estado..... 62

Tabela 7 - Proporção de alunos descendentes de estrangeiros nos grupos escolares situados em bairros operários.

Tabela 8 - Proporção de alunos descendentes de estrangeiros nos grupos escolares do interior.

Tabela 9 - Número de matrículas, por sexo, nas escolas isoladas de todo o Estado $(1898-1916)$

Tabela 10 - Número de escolas isoladas providas na Capital e no interior (1898-1925).

Tabela 11 - Escolas reunidas transformadas em grupo escolar. 74

Tabela 12 - Programas de ensino publicados entre 1887 e $1904 \ldots$ 90

Tabela 13 - Programas de ensino publicados entre 1905 e 1918. 101

Tabela 14 - Programas de ensino publicados nos anos de 1920 105 


\section{LISTA DE FIGURAS}

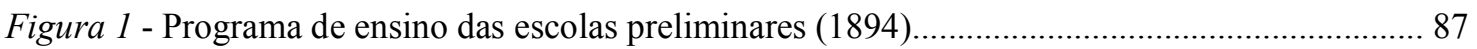

Figura 2 - Programa de ensino das escolas-modelo e dos grupos escolares (1904).......................... 89

Figura 3 - Programa de ensino das escolas-modelo e dos grupos escolares (1905).......................... 91

Figura 4 - Programa de ensino das escolas isoladas (1911).................................................................

Figura 5 - Horário-modelo das escolas-modelo isoladas (1911)......................................................97

Figura 6 - Programa de ensino das escolas de bairro (1913)...........................................................99 


\section{SUMÁRIO}

INTRODUÇÃO

CAPÍTULO 1 - O NOVO CENÁRIO PAULISTA: CRESCIMENTO DEMOGRÁFICO, EXPANSÃO URBANO-INDUSTRIAL E MODERNIZAÇÃO DO ENSINO.............................................................

1.1. O Estado de São Paulo na vanguarda do país. .30

1.1.1. Retrato de uma cidade em rápida mudança: São Paulo e a modernização.. .34

1.2. A criação e a expansão dos diferentes tipos de escolas primárias no contexto do processo de modernização educacional. 48

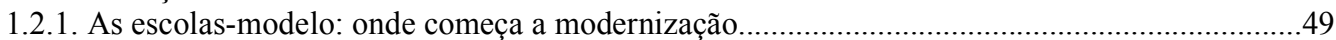

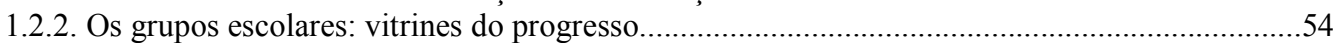

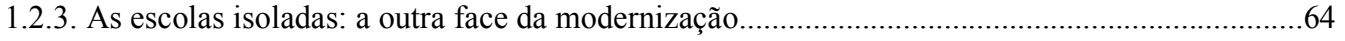

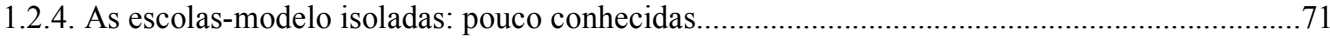

1.2.5. As escolas reunidas e sua trajetória singular...........................................................

CAPÍTULO 2 - NACIONALIZAR E MORALIZAR O POVO: OS PROGRAMAS DE ENSINO

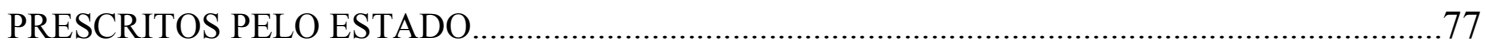

2.1. O que as escolas primárias paulistas deviam ensinar antes da diferenciação dos programas de ensino .78

2.2. O início da diferenciação dos programas de ensino. .91

2.3. As finalidades dos programas de ensino oficiais. 109

CAPÍTULO 3 - A INTERAÇÃO ENTRE OS DIVERSOS SUJEITOS ESCOLARES E OS

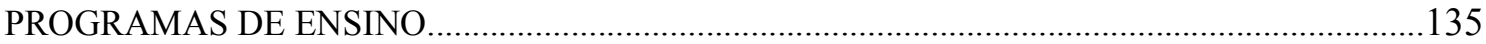

3.1. Considerações gerais em torno da questão dos programas de ensino...........................................136

3.2. O que ensinar como objeto de disputas.

3.3. As distâncias entre o que determinavam os programas de ensino e o que se ensinava nas escolas primárias

CONSIDERAÇÕES FINAIS. 170

FONTES E REFERÊNCIAS BIBLIOGRÁFICAS.

ANEXOS (CD-ROM) 


\section{INTRODUÇÃO}

Português, Ciências, Educação Artística, Estudos Sociais, Matemática, Educação Física... Se puxássemos pela memória, cada um de nós seria capaz de se recordar de ao menos uma matéria estudada no ensino primário, seja porque era aquela de que mais gostávamos ou, ao contrário, aquela menos predileta. Tão acostumados estamos com o fato de que a passagem pela escola implica na aprendizagem de determinados saberes, que - à exceção dos esporádicos debates veiculados pela imprensa em torno da reformulação dos currículos ${ }^{1}$ raramente os tomamos como objeto de reflexão. Com a naturalização daquilo que se ensina na escola, aspectos fundamentais para a compreensão do papel dela deixam de ser problematizados, especialmente numa perspectiva histórica. Exemplo disso é o questionamento que norteia o presente trabalho: "o que deviam aprender as crianças que freqüentavam as escolas públicas primárias paulistas entre 1887 e 1929”? A resposta, embora aparentemente simples, não o é quando se considera que, no período acima delimitado, os grupos escolares não eram sinônimos de escolas primárias. Paralelamente a eles, predominaram no Estado de São Paulo outras modalidades de escolas públicas primárias, quais sejam, as escolas-modelo, as escolas isoladas, as escolas-modelo isoladas e as escolas reunidas. À época, os saberes escolares (matérias² e conteúdos) vinham definidos nos chamados programas de ensino, os quais eram encontrados na legislação escolar. Para cada um dos tipos de escolas, no entanto, havia um programa de ensino específico a ser cumprido, significando, portanto, que o público escolar primário não tinha a oportunidade de acesso aos mesmos saberes escolares.

\footnotetext{
${ }^{1}$ A mais recente discussão envolveu a volta das disciplinas Filosofia e Sociologia ao currículo do Ensino Médio das escolas particulares e públicas (Lei n. 11.684, de 02 de junho de 2008).

2 A opção em empregar a palavra matéria e não disciplina deveu-se a dois fatores. Primeiramente, porque é aquela que se adota na legislação escolar de 1887 até 1929, ou seja, nos artigos relativos aos programas de ensino (por exemplo, no Decreto n. 144-B, de 30 de dezembro de 1892: "Art. 17 - O Conselho Superior: $\S 1^{\circ}$. - Em seguida organizará também o regimento interno das referidas escolas, especificando minuciosamente em programas para cada série as matérias que constituem o ensino") e nos programas de ensino propriamente ditos (como no "Art. $6^{\circ}$. - O ensino das escolas preliminares compreenderá as matérias seguintes" da Lei n. 88, de 08 de setembro de 1822). Em segundo lugar, por considerá-la mais adequada ao nível de ensino do qual trata o trabalho. De fato, como sustenta Forquin (1992, p.47), atualmente as palavras matéria e disciplina são, muitas vezes, utilizadas indistintamente, mas "com uma nuance de sentido: o termo 'matéria' é mais neutro, mais popular, mais 'escolar' e mais 'primário', enquanto o termo 'disciplina' se aplica mais aos níveis superiores dos cursos e implica sempre uma idéia de exercício intelectual e de formação do espírito”.
} 


\section{Objetivos, justificativa e referencial teórico}

O objetivo da dissertação de mestrado aqui apresentada foi investigar os programas de ensino elaborados de 1887 a 1929 no Estado de São Paulo, identificando os saberes escolares escolhidos para serem ensinados nos grupos escolares, nas escolas-modelo, nas escolas isoladas, nas escolas-modelo isoladas e nas escolas reunidas. A partir do exame dos programas de ensino, buscou-se atentar para aspectos como a permanência, o acréscimo e/ou a exclusão de determinados saberes escolares, além do modo como esses eram apresentados, isto é, se eram apenas descritas as matérias que deviam ser ensinadas ou se eram também detalhados os conteúdos de cada uma delas. Cabe ressaltar, porém, que as orientações metodológicas presentes em alguns dos programas de ensino não fizeram parte do estudo, na medida em que esse está circunscrito ao problema do que ensinar. Outro objetivo do trabalho foi procurar referências à questão dos programas de ensino, feitas por diversos profissionais da educação ao longo do período. Para tanto, foram utilizadas outras fontes produzidas entre 1887 e 1929: relatórios de professores, de diretores de escolas-modelo e de grupos escolares, e de inspetores escolares. Tais materiais encontram-se sob a forma de manuscritos, com exceção dos relatórios de inspetores escolares escritos a partir de 1907, que, então, passaram a ser incluídos nos Anuários do Ensino do Estado de São Paulo (1907-1926)³. Além disso, recorreu-se a textos de três periódicos educacionais paulistas: Revista de Ensino (19021918), Revista Escolar (1925-1927) e Educação (1927-1929) ${ }^{4}$.

O tema da presente dissertação surgiu a partir de duas constatações. A primeira delas é a de que ainda é incipiente o interesse da área da História da Educação Brasileira em torno das diferentes escolas públicas primárias. Um dos poucos autores e, ao que tudo indica, um dos primeiros, que as incorporaram em suas análises históricas está Heládio César Gonçalves Antunha. Seu livro A instrução pública no Estado de São Paulo - a Reforma de 1920 (1976), cujo objeto central é a Reforma Sampaio Dória, realizada em 1920, apresenta uma quantidade significativa de informações sobre as escolas isoladas, os grupos escolares e as escolas reunidas. Já em sua tese de doutoramento, intitulada Da era das cadeiras isoladas à era dos grupos escolares na Paraíba (2002), Antonio Carlos Ferreira Pinheiro, ao tratar da implementação do sistema público primário paraibano, divide-o em dois longos períodos, os

\footnotetext{
${ }^{3}$ Os Anuários do Ensino foram publicados até 1937.

${ }^{4}$ Os períodos definidos entre parênteses coincidem com o ciclo de vida das revistas, exceto Educação, que circulou até 1961.
} 
quais denomina de era das cadeiras isoladas ${ }^{5}$ e era dos grupos escolares. A primeira delas começou com a criação, em 1783, das "aulas régias", as quais permaneceram até os anos de 1915-16, quando foram, pouco a pouco, sendo substituídas por um outro modelo de organização escolar, a saber, os grupos escolares. A periodização seguida por Pinheiro vai de 1849 a 1949, dado que ele observa (2002, p.06) que, antes do marco inicial, o modelo das cadeiras isoladas não estava totalmente difundido na Paraíba. Durante esse longo intervalo, foram introduzidas as chamadas escolas reunidas, tidas como transitórias, já que seriam transformadas em grupos escolares gradativamente, conforme aumentasse a demanda. Por sua vez, Rita de Cassia Gallego, em sua dissertação de mestrado Uso(s) do tempo: a organização das atividades de alunos e professores nas escolas primárias paulistas (1890-1929) (2003), leva em conta não apenas os grupos escolares, como também as escolas-modelo, as escolas isoladas e as escolas reunidas para examinar o processo de construção da arquitetura temporal das escolas primárias do Estado de São Paulo, no tocante à configuração tanto dos quadros horários a serem seguidos na organização das atividades de alunos e professores (definiam, por exemplo, a distribuição diária e semanal das matérias e o tempo de descanso), quanto dos elementos constitutivos do calendário escolar, tais como a data de matrícula e o início e término do ano letivo. Considerando essas mesmas variedades de escolas primárias paulistas, Renata Marcílio Cândido, em sua dissertação de mestrado Culturas da escola: as festas nas escolas públicas paulistas (1890-1930) (2007), mostra as festas que nelas ocorreram e que, desse modo, ajudaram a disseminar um ideal de escola e de sociedade republicana. Por fim, há a dissertação de mestrado de Denise Guilherme da Silva, cujo título é "Ilhas de saber": prescrições e práticas das escolas isoladas do estado de São Paulo (1933-1943) $(2004)^{6}$, e a produção bibliográfica de Zeila de Brito Fabri Demartini sobre as escolas rurais paulistas da Primeira República ${ }^{7}$. Apesar de incidirem especialmente sobre as escolas isoladas - que se concentravam, em sua maioria, nas áreas rurais - representam trabalhos significativos, pois contribuem para preencher uma lacuna ainda existente na área da História da Educação Brasileira, como já explicitado. Silva averigua as práticas das escolas isoladas a partir das representações construídas acerca delas, bem como as prescrições

\footnotetext{
${ }^{5}$ Na visão de Pinheiro, embora a expressão "escola isolada" já ter sido "consagrada pela historiografia educacional brasileira (...) sugere uma organização institucional mais complexa e também mais próxima da atual" (2002, p.08). Por isso, o autor prefere utilizar o termo "cadeiras isoladas", que denotam aquelas mantidas "sob precário controle do Estado, além de ter seu funcionamento pedagógico quase sempre subordinado única e exclusivamente ao arbítrio do próprio professor, detentor da cadeira" (2002, p.09, grifo do autor).

${ }^{6}$ Nas palavras de Silva (2004, p.71): “Em meio aos 'mares' das moléstias e do atraso comum às populações rurais, as escolas isoladas configuraram-se como 'ilhas' de saber, de saúde e de progresso, que deveriam transformar o ambiente e a conduta do "caipira".

${ }^{7}$ Ver as Referências Bibliográficas.
} 
emanadas dos inspetores escolares no sentido de aproximar esse tipo de escola primária àquele tido como exemplar, quais sejam, os grupos escolares. Entre os textos de Demartini, é possível destacar Cidadãos analphabetos: propostas e realidade do ensino rural em São Paulo na 1 ${ }^{a}$. República (1989), que revela o privilégio concedido pelo Estado ao ensino primário destinado às populações urbanas, relegando, assim, aquele que se ministrava nas zonas rurais.

A outra constatação é a de que o conjunto de pesquisas acerca da história dos programas do ensino primário, no âmbito brasileiro, também é pouco expressivo e, nele, o tema da dissertação de mestrado aqui apresentada ainda não foi contemplado. Como exemplo, no artigo Produção didática e programas de ensino das escolas paulistas nas primeiras décadas do século XX (1989), Circe Maria Fernandes Bittencourt discorre sobre as obras didáticas e os programas destinados ao ensino de História nas escolas públicas primárias e ginasiais paulistas, no período 1917-1940. A ênfase da autora, todavia, recai sobre o primeiro tipo de material. Quanto a Ricardo Ribeiro, num dos capítulos da sua tese de doutoramento Professoras de outrora: escola primária paulista (1925-1950) (1996), ele examina as orientações metodológicas oficiais sobre o ensino das matérias que integravam o programa de ensino dos grupos escolares vigente a partir de $1926^{8}$. Rosa Fátima de Souza, por sua vez embora reconheça a existência de uma diversidade de escolas primárias paulistas - em parte de seus trabalhos ${ }^{9}$ e no texto A militarização da infância: expressões do nacionalismo na cultura brasileira (2000) ocupa-se com os principais programas de ensino dos grupos escolares do Estado de São Paulo, mas se preocupando, em especial, com os modos pelos quais eles buscavam contribuir com a formação da nacionalidade brasileira. Já Ariclê Vechia escreve no texto $\mathbf{O}$ plano de estudos das escolas públicas elementares na Província do Paraná: ler e escrever, para Deus e o Estado (2004) sobre os programas de ensino que nortearam as escolas públicas primárias da Província do Paraná, no decorrer do período imperial. Por fim, Rita de Cassia Gallego, em sua tese de doutoramento Tempo, temporalidades e ritmos nas escolas primárias públicas em São Paulo: heranças e negociações (1846-1890) (2008), reserva um dos capítulos para verificar como as modificações que foram sendo operadas nos programas de ensino previstos entre 1846 e 1887

\footnotetext{
${ }^{8} \mathrm{O}$ objetivo da tese foi “(re)conhecer a escola primária no cotidiano do trabalho da professora, com especial destaque para as suas práticas e relações educacionais” (Ribeiro, 1996, p.10).

${ }^{9}$ Ver Souza (1997; 1998; 2004; 2008).
} 
para as escolas públicas primárias paulistas influenciaram a ordenação do tempo nas $\operatorname{mesmas}^{10}$.

Do mesmo modo, ainda é exíguo o número de trabalhos voltados à história de determinadas matérias que compunham os programas do ensino primário. À guisa de ilustração, Circe Maria Fernandes Bittencourt, em sua dissertação de mestrado Pátria, civilização e trabalho - O ensino de História nas escolas paulistas (1917-1939) (1988), retrata a função do ensino de História nas escolas primárias e ginasiais paulistas. Já Tarcísio Mauro Vago, na sua tese de doutoramento Cultura escolar, cultivo de corpos: Educação Physica e Gymnastica como práticas constitutivas dos corpos de crianças no ensino público primário de Belo Horizonte (1906-1920) (1999), detalha como a "Ginástica" foi utilizada, nos grupos escolares da Capital mineira, como dispositivo de intervenção nos corpos infantis. Vera Lúcia Gomes Jardim, por sua vez, na sua dissertação de mestrado Os sons da República: o ensino da Música nas escolas públicas de São Paulo na Primeira República - 1889-1930 (2003), dedica-se à história da Música nas escolas primárias, no que tange à legislação, aos métodos de ensino e às orientações sobre o ensino da matéria. A mesma autora, na sua tese de doutoramento Da arte à educação: A música nas escolas públicas - 1838-1971 (2008), debruça-se sobre as diferenças entre o ensino escolar e o ensino especializado da Música. Por último, Ailton Pereira Morila, no texto intitulado No compasso do progresso: a música na escola nas primeiras décadas republicanas (2006), trata das funções da Música na escola pública primária paulista dos decênios iniciais da República, bem como das principais temáticas presentes nas canções escolares.

Como foi possível entrever, a área da História da Educação Brasileira ainda carece de estudos que versem seja sobre a multiplicidade de tipos de escolas primárias, seja sobre os saberes escolares transmitidos nesse nível de ensino ${ }^{11}$. Por isso, a presente dissertação de mestrado buscou contribuir de duas formas. Uma delas foi enfatizar que, sem minimizar a história dos grupos escolares ${ }^{12}$, aquela das demais escolas primárias também deve ser valorizada, tendo em vista que delas dependeram a escolarização de amplas parcelas da

${ }^{10} \mathrm{O}$ intuito da tese foi compreender os processos de construção do tempo nas escolas primárias paulistas, entre 1846 e 1890, período em que os sistemas públicos primários de ensino emergiam no âmbito mundial (2008, p.24).

${ }^{11}$ Ao que parece, são mais comuns as investigações sobre o ensino secundário. Ver, por exemplo, PILETTI, Nelson. Evolução do currículo do curso secundário no Brasil. Revista da Faculdade de Educação. São Paulo, 13(2), p.27-72, jul./dez. 1987.

${ }^{12}$ Como assinalam Faria Filho e Souza (2006, p.24), é necessário "reconhecer a relevante contribuição que os estudos históricos sobre os grupos escolares têm trazido para a história do ensino primário e da escola pública no Brasil. De fato, a história desse nível de ensino foi por muito tempo secundarizada, especialmente se comparada à história das idéias pedagógicas ou mesmo à história dos ensinos secundário e superior". 
população brasileira (Souza, 2004). A outra foi continuar a desvendar a "caixa-preta" da escola, como sugere Julia (2001). Isso implicou substituir abordagens externalistas sobre a escola, como fazem, por exemplo, a história das idéias pedagógicas, a história das instituições educativas e a história das populações escolares, por uma outra, que incorreu sobre o cotidiano interno da escola, ou seja, sobre a cultura escolar, tal como a define Julia (2001, p.10-11, grifos do autor):

(...) poder-se-ia descrever a cultura escolar como um conjunto de normas que definem conhecimentos a ensinar e condutas a inculcar, e um conjunto de práticas que permitem a transmissão desses conhecimentos e a incorporação desses comportamentos; normas e práticas coordenadas a finalidades que podem variar segundo as épocas (finalidades religiosas, sociopolíticas ou simplesmente de socialização). Normas e práticas não podem ser analisadas sem se levar em conta o corpo profissional dos agentes que são chamados a obedecer a essas ordens e, portanto, a utilizar dispositivos pedagógicos encarregados de facilitar sua aplicação, a saber, os professores primários e os demais professores.

Mas se os programas de ensino - enquanto deviam obrigatoriamente ser seguidos pelos professores, e, pois, como normas - podem ser interpretados como parte da cultura escolar tal como formulada por Julia, é preciso considerar que a mesma também recobre outras dimensões da organização didático-pedagógica. Com efeito, para Viñao Frago (1995), a cultura escolar é toda a vida escolar. Apesar disso, ele ressalta que dois elementos organizadores sobressaem-se, dado que "afetam o ser humano em cheio, em sua consciência interior, em todos seus pensamentos e atividades, de modo individual, grupal e como espécie em relação com a natureza de que toma parte" (1995, p.69): o espaço e o tempo escolares. Em contraste com a noção de cultura escolar do autor, não obstante, o programa de ensino é aqui concebido como o eixo em torno do qual giram todos os demais componentes da cultura escolar. De fato, como delimitar o tempo de ensino de cada matéria sem a prévia definição do que deve ser ensinado? Ou ainda: os espaços não devem ser preparados de acordo com o que é necessário para o ensino de certas matérias, como a Educação Física? Ademais, sem desmerecer a importância de outros aspectos da cultura escolar, como deixar de observar que são os programas de ensino que evidenciam a especificidade do papel da escola, isto é, que ela representa um espaço próprio, diferente de outras agências de socialização como a Igreja e a família, em suma, que ela "não é apenas (...) um local onde circulam fluxos humanos, onde se investem e se gerem riquezas materiais, onde se travam interações sociais e relações de poder; ela é também um local - o local por excelência nas sociedades modernas - de gestão e de transmissão de saberes e de símbolos" (Forquin, 1992, p.28). 
Se os programas de ensino consistem então no núcleo da cultura escolar, eles não são atemporais, como também é possível depreender do conceito de Julia (2001). Nessa mesma direção, o inglês Ivor Goodson (1997), ao propor a história social do currículo, argumenta que - embora concebido como um aspecto neutro - o currículo ${ }^{13}$ é um artefato social e histórico, elaborado para se atingir os objetivos da escola. Ele acrescenta, porém, que o currículo - mais do que consistir num mero resultado de um processo de construção social, no qual certos grupos sociais lutam para fazer valer seus interesses - é um mecanismo de diferenciação social. A presente dissertação mostra, com efeito, que a opção em se criar programas de ensino próprios para cada tipo de escola primária, levando-se em conta o meio em que ela se localizava, teve como intuito a manutenção das desigualdades sociais. De modo geral, isso significava que se, nas escolas-modelo e nos grupos escolares, o período de duração do curso e os programas de ensino eram mais extensos, nas escolas isoladas, ambos eram mais reduzidos, o que se tornou um empecilho para a mobilidade social dos habitantes do campo.

Além dos ingleses, também os norte-americanos têm se interessado pela história social do currículo. Nesse caso, essa vertente de pesquisa originou-se da constituição do currículo como um campo profissional, isto é, especializado, de estudos. O marco inicial desse campo foi a publicação, no país, do livro The curriculum (1918), de Franklin Bobbitt. Outro aporte teórico utilizado no trabalho aqui apresentado foi a chamada história das disciplinas escolares, mais comumente desenvolvida na Europa, notadamente na França. Essa tradição de pesquisa, assim como a história social do currículo praticada na Inglaterra, tem como objeto principal de investigação as disciplinas do ensino secundário (Silva, 2005; Souza, 2005). No entender de Chervel (1991) e de Julia (2001, 2002), é a história das disciplinas escolares que permite que a cultura escolar seja desvelada. Para tanto, os autores defendem a análise articulada de três eixos, quais sejam, as finalidades da disciplina, o funcionamento da disciplina (conteúdos, métodos e práticas) e os resultados do ensino (a apropriação pelo aluno dos ensinamentos a ele dispensados). Longe de serem conflitantes, tanto a história social do currículo, quanto a história das disciplinas escolares ofereceram importantes subsídios. Isso

\footnotetext{
${ }^{13} \mathrm{Na}$ periodização escolhida para a dissertação (1887-1929), o termo "currículo" ainda não era utilizado nas fontes examinadas. Possivelmente, a introdução da palavra no vocabulário educacional brasileiro esteja vinculada ao início do pensamento curricular no país. Moreira (1990) explica que o campo do currículo no Brasil se originou apenas nos anos 1920 e 1930 a partir, inicialmente, das reformas educacionais promovidas pelos pioneiros da Escola Nova nos estados e, mais tarde, da base institucional do Instituto Nacional de Estudos e Pesquisas Educacionais (INEP) e do Programa de Assistência Brasileiro-Americana à Educação Elementar (PABAEE). Entre as reformas, o autor destaca aquelas organizadas por Anísio Teixeira (Bahia), Francisco Campos e Mário Casassanta (Minas Gerais) e Fernando de Azevedo (antigo Distrito Federal).
} 
porque a primeira não pode dispensar a segunda, na medida em que é através do exame das funções de cada uma das disciplinas que integram o currículo que é possível ter uma visão geral do que o mesmo visa ${ }^{14}$.

\section{Periodização e fontes}

No que concerne ao período delimitado para o trabalho, a opção pelo ano de 1887 deveu-se ao fato de que, em 06 de abril, foi publicado, no âmbito de uma Reforma na Instrução Pública, o programa de ensino do $1^{\circ}$. grau (Lei n. 81) ao qual se assemelha, com pequenas modificações, o primeiro programa de ensino voltado exclusivamente para uma modalidade de escola primária que é, nesse caso, a escola-modelo (Decreto n. 27, de 12 de março de 1890). Já 1929 foi o último ano em que foram publicados programas de ensino que variavam de acordo com o tipo de escola primária (Decreto n. 4600, de 30 de maio) antes da Reforma de 1931, organizada pelo então Diretor Geral da Instrução Pública de São Paulo, Lourenço Filho. Inspirada no movimento da Escola Nova, a Reforma procurou "racionalizar o espaço e as práticas da escola, transformando-a em uma espécie de agência civilizadora da sociedade" (Mate, 2002, p.105, grifos da autora). Recebendo ampla autonomia didática, tida como um dos pontos principais da Reforma, os professores foram solicitados a planejar seus próprios programas de ensino, mas com a ressalva de que fossem programas "que os alumnos possam aprender, não programmas que os alumnos devam aprender"15 (Lourenço Filho, $A$ questão dos programmas. Escola Nova, nov.-dez./1930, n. 02, p.82) ${ }^{16}$. Conforme será explicitado posteriormente, antes dessa Reforma, os professores não participavam da criação

\footnotetext{
${ }^{14}$ As próprias trajetórias de pesquisa de André Chervel e de Ivor Goodson interligam a história do currículo e a história das disciplinas escolares. O primeiro "iniciou suas investigações, na década de 1970, pela história do ensino de francês a partir do final do século XIX e suas reflexões seguintes levaram-no a situar e acompanhar historicamente os currículos nos quais se inseria esta disciplina" (Bittencourt, 2003, p.21). Já Goodson salientou que seu trabalho "começou como uma forma de entender de que modo as disciplinas do currículo escolar afetavam a vida dos alunos e professores. Eu lecionava algumas disciplinas bastante incomuns - uma delas se chamava Estudos Ambientais - que não eram consideradas disciplinas propriamente ditas. Então eu queria descobrir de onde tinham vindo as disciplinas propriamente ditas, como a biologia, e porque elas pareciam não ter muito interesse para os estudantes. Quais eram os motivos políticos, sociais e históricos daquele fato? Então comecei a analisar o histórico de uma série de disciplinas e também o contexto da entrada de novas disciplinas no currículo escolar, já que a nova disciplina era Estudos Ambientais e as tradicionais lutavam contra ela" (2007, p.121).

${ }_{15}^{15}$ Ao longo de toda a dissertação de mestrado, a grafia e a acentuação originais foram mantidas.

${ }^{16}$ Em 1934, foi aprovado um "Programa mínimo para o curso primário", para atender ao tresdobramento do horário de funcionamento dos grupos escolares, mas ele acabou se tornando o " "programa' efetivo da escola primária”, ao ser seguido mesmo pelos grupos não tresdobrados (Ribeiro, 1996, p.89).
} 
dos programas de ensino.

Tomar o ano de 1887 como baliza inicial também tem o propósito de mostrar que a preocupação com o que ensinar nas escolas primárias emergiu antes mesmo da proclamação da República e esteve vinculada às condições históricas nos planos mundial, nacional e estadual. Por volta de 1870, a Revolução Científico-Tecnológica, mais conhecida como Segunda Revolução Industrial, provocou a globalização de uma nova ordem econômica: o capitalismo. Também a partir dela, inúmeras invenções, tais como o automóvel, o avião, o telefone, o rádio, o cinema, a fotografia, o raio-X e a anestesia - frutos do desenvolvimento de novas fontes de energia, como a eletricidade - passaram, num ritmo acelerado, a fazer parte do cotidiano das populações, alterando profundamente seus hábitos e costumes. Era o início dos "tempos modernos", marcados pelo avanço da razão, das ciências e das artes. Embora os países mais adiantados da Europa e os Estados Unidos tenham sofrido os primeiros impactos dessas mudanças, o ingresso do Brasil na modernidade não tardou, tendo sido engendrado por uma nova elite formada por jovens políticos, militares, intelectuais e artistas, que visitavam com freqüência aquelas partes do mundo. Junto com eles, trouxeram uma nova corrente de idéias, inspiradas principalmente no liberalismo, no positivismo e no evolucionismo social. $\mathrm{Na}$ então Província de São Paulo, o processo de modernização era encabeçado pelos fazendeiros do Oeste Paulista, enriquecidos com a renda gerada pelo café e que, aliados aos militares, derrubaram, mais tarde, a monarquia. Concomitantemente, o futuro Estado de São Paulo assistia ao começo da urbanização e da imigração em massa (Sevcenko, 2006).

A escola pública, como não poderia deixar de ser, não escapou dos "ventos da modernização". Político influente no período de sua atuação, Rui Barbosa estava imbuído do duplo sentido dessa relação: o de que a educação era alavanca para a modernização do país e o de que o advento da sociedade moderna exigia a reorganização didático-pedagógica das escolas primárias. Quanto ao segundo caso, nos Pareceres sobre a Reforma do ensino primário e várias instituições complementares da instrução pública ${ }^{17}$ que redigiu, em 1882, ele propôs a adoção do método intuitivo e a renovação do programa de ensino como bases da modernização da educação popular (Souza, 2000b). Com a inauguração da República, o desejo de tornar o Brasil moderno e, logo, o de superar o passado, visto como sinônimo de atraso, não apenas persistiu, como recebeu um novo impulso, ao ser erigida como

\footnotetext{
${ }^{17}$ Relator da Comissão de Instrução Pública, Rui Barbosa apresentou ao Parlamento, em 1882, dois pareceres: um sobre o ensino primário e outro sobre o ensino secundário e superior. Baseados em trabalhos de autores estrangeiros, em especial franceses e ingleses, os documentos foram produzidos para servirem de apoio ao debate do projeto de Reforma do Ensino Primário e Secundário no Município da Corte e do Superior em todo o Império, que iriam substituir a Reforma implantada por Leôncio de Carvalho, em 1879 (Souza, 2000b).
} 
aquela que possibilitaria o alinhamento do país ao nível das principais potências econômicas. Somava-se a isso o fato de que a inauguração do regime republicano coincidiu com a "Belle Époque" (1890-1914) na Europa e nos Estados Unidos, uma fase de amplo crescimento econômico, no qual o progresso era "a palavra-chave (...): maciço, iluminado, seguro de si mesmo, satisfeito mas, acima de tudo, inevitável. Quase nenhum dos homens com poder e influência em todos os acontecimentos no mundo ocidental desejou pôr-lhe um freio" (Hobsbawm, 1982, p.24). A partir da República, a escola primária, até então vista como motor para o progresso e alçada ao papel de instrumento de formação do homem moderno, ganhou finalidades políticas de vulto: a de preparação para a cidadania e a de divulgação dos valores republicanos.

No empenho das elites em transformar o Brasil, a legislação escolar consistiu num instrumento modernizador indispensável. Através de leis, decretos e regulamentos, o Estado fixava as regras de organização escolar no que se referia aos âmbitos administrativo e didático-pedagógico. Antes de defini-las, era necessário o debate de idéias, para o qual modelos educacionais estrangeiros serviam como referência, tais como o francês, até 1870, e o norte-americano, a partir do final do século XIX (Reis Filho, 1995). A legislação escolar é, portanto, a materialização ou a prática de um determinado pensamento pedagógico (Faria Filho, 1998). Isso significa que a lei é composta por textos que, por sua vez, materializam um discurso, no qual estão incorporadas concepções diversas, como a de criança, de homem, de mundo e de educação (Correia; Silva, 2004). Os programas de ensino, nesse caso, representavam a formalização escrita daquilo que foi anteriormente debatido. Eles constituíam, pois, textos oficiais, cuja função era prescrever "uma escola ideal, coerente e eficaz, na qual os meios e os fins se articulam de modo seguro, sem jogo ou atritos, na evidente racionalidade das palavras que explicam pacientemente o que deve ser o mundo e como fazer para que ele assim seja" (Chartier; Hébrard, 1995, p.249).

Os programas de ensino, integrantes do corpus documental da presente dissertação de mestrado, foram os primeiros materiais reunidos, o que foi possível a partir da Coleção de Leis e Decretos do Estado de São Paulo, publicada pela "Imprensa Oficial" e que pode ser localizada na Biblioteca da Faculdade de Educação da Universidade de São Paulo e na Biblioteca da Faculdade de Filosofia, Letras e Ciências Humanas da Universidade de São Paulo. Para tanto, foi imprescindível o Índice básico de legislação do ensino paulista (18901945), de Casemiro dos Reis Filho (1998), embora tenha sido necessária, em alguns momentos, a consulta do próprio sumário da Coleção. Os programas de ensino eram 
publicados sob três diferentes formas: como objeto de "Artigos" de leis e decretos - que regulamentam as primeiras; como anexos de decretos; como objeto de decretos destinados especialmente a aprová-los e fazê-los serem cumpridos. Nos Anexos 2 a 6 estão sistematizadas, respectivamente, as informações principais relativas aos programas de ensino das escolas-modelo, dos grupos escolares, das escolas isoladas, das escolas-modelo isoladas e das escolas reunidas. Além dos programas de ensino propriamente ditos, ao longo do processo de análise da legislação escolar foram selecionados leis e decretos - vide Anexo 1 - que indicassem os momentos em que esses cinco tipos de escolas primárias fizeram parte do sistema de ensino primário paulista. No Anexo 7, foram incluídas algumas informações gerais sobre a questão dos programas de ensino, encontradas também na legislação escolar.

A despeito da relevância do estudo dos programas de ensino para a compreensão das expectativas depositadas pelo poder público em cada uma das modalidades de escola primária, eles não permitem inferir outros aspectos, tais como: o modo como um novo programa de ensino era recebido pelos profissionais da educação; as apreciações dos mesmos sobre programas de ensino vigentes; os conflitos de interesses em torno do que se devia ensinar; as diferenças entre os programas de ensino prescritos e aqueles executados. Utilizar apenas a legislação escolar como fonte histórica, em suma, significaria desconsiderar que os sujeitos escolares, os professores em particular, apesar de levados a obedecer às normas impostas pelo Estado, não deixavam de colaborar ativamente na produção da cultura escolar. Assim sendo, foram examinados outros materiais que circularam entre 1887 e 1929, quais sejam, relatórios de ensino e textos de revistas pedagógicas. As passagens mais relevantes dos relatórios de professores, de diretores de escolas e de inspetores escolares, bem como dos textos da Revista de Ensino, da Revista Escolar e de Educação podem ser visualizadas, respectivamente, nos Anexos 8 a 13.

Os relatórios de ensino estão disponíveis sob a forma de manuscritos no "Arquivo Público do Estado de São Paulo”, que os acondicionam em latas. A princípio, foram manejadas aquelas classificadas com os subtítulos Relatórios e Relatórios do Ensino Público. Num momento posterior, a consulta estendeu-se para as latas nas quais não havia subtítulo, somente o título Secretaria do Interior - Inspetoria do Ensino e Secretaria do Interior Escolas Modelo. Embora a intenção inicial fosse apenas a busca de relatórios de inspetores escolares, como previa o projeto de pesquisa, nessas latas foram encontrados também relatórios escritos por outros profissionais, a saber, os professores - de escolas preliminares, em sua maioria - e os diretores de escolas (escolas-modelo e grupos escolares), além de vários 
outros tipos de documentos, tais como ofícios, correspondências e exames de alunos. A leitura dos relatórios de professores e de diretores mostrou que ambos trazem referências importantes acerca da questão dos programas de ensino. Por isso, eles também foram integrados ao conjunto de fontes.

No processo de levantamento de dados nos relatórios, certos fatores dificultaram o andamento do mesmo, como por exemplo, o fato de que alguns dos papéis que serviram de suporte à escrita estão demasiadamente amarelados e/ou rasgados; a ausência de ordem cronológica na organização dos relatórios e a caligrafia que, não raro, era ilegível. Apesar disso, foi possível reunir 35 relatórios de professores (que abrangem o período 1890-1897); 23 de diretores de grupos escolares (1897-1907); 3 de diretores de escolas-modelo (1898-1899) e 12 de inspetores escolares (1896-1906). Os últimos também podem ser encontrados nos Anuários do Ensino do Estado de São Paulo ${ }^{18}$ (de 1907 em diante). Nesse caso, contudo, não foram localizados os números correspondentes aos anos de 1927, 1928 e 1929. Alguns Anuários foram consultados no acervo de obras raras da Biblioteca da Faculdade de Educação da Universidade de São Paulo e outros no "Instituto de Estudos Educacionais Sud Mennucci", do Centro do Professorado Paulista. A partir deles, foram selecionados 30 relatórios de inspetores escolares (1907-1918).

Embora não seja explícito seu caráter oficial, os relatórios de professores, diretores de escolas e inspetores escolares eram confeccionados para cumprir determinadas exigências legais. À guisa de ilustração, o Decreto n. 144-B, de 30 de dezembro de 1892, no art. $130 \S$ 14, determina que os professores do curso preliminar deviam "enviar ao Diretor Geral ${ }^{19}$ por intermedio dos inspectores de districto, em $1^{\circ}$. de junho e de novembro de cada anno, um relatorio sobre o estado de suas escolas e adiantamento de seus discipulos, acompanhado de um mapa" ${ }^{20}$. A partir de 1897, os relatórios de professores escolhidos sinalizam que quem os

18 Tratam-se de publicações oficiais que, simultaneamente, informam, disciplinam e celebram o sistema educacional (Catani, 1995). Entre os conteúdos dos Anuários estavam, além dos relatórios dos inspetores escolares, quadros estatísticos sobre o movimento escolar no Estado e fotografias de edifícios escolares.

19 A "Diretoria Geral da Instrução Pública" que - antes de 1894, era chamada de "Secretaria Geral da Instrução Pública" - foi reconhecida como órgão burocrático escolar através do Decreto n. 144-B, de 30 de dezembro de 1892. No conjunto da organização administrativa do Estado, a posição da Diretoria Geral da Instrução Pública "era de uma relativa independência, pois era considerada uma entidade anexa ou apensa à Secretaria do Interior, devendo prestar contas a esta" (Tavares, 2004, p.93).

${ }^{20}$ Apesar da indicação dos professores de que tais mapas vinham anexados aos relatórios, eles não foram localizados nas latas. Como conclui Vidal (2008, p.43-44), os mapas de freqüência já vinham sendo produzidos pelos professores, em São Paulo, desde a primeira metade do século XIX, para servir como "estratégia de comprovação de efetivo exercício docente (documento necessário para o recebimento do salário) e de viabilidade da escola (atestado imprescindível de atendimento ao número mínimo de alunos exigido por lei para manutenção da aula)". 
recebia não era mais o Diretor Geral e sim o Secretário dos Negócios do Interior ${ }^{21}$. Também através da análise dessas fontes, foi possível notar que o tema central debatido pelos professores eram os problemas com os quais se deparavam na execução dos programas de ensino, especialmente a falta de materiais pedagógicos e a de habilitação profissional para o ensino de determinadas matérias. Cabe ainda ressaltar que, devido a essa temática que os unia, os relatórios eram muito similares e até mesmo repetitivos, já que alguns deles são de autoria dos mesmos professores. Entre eles, destacam-se: Maria Marcolina Pinheiro (5 relatórios), Maria Eugenia Nunes (4 relatórios) e Joaquim Lopes da Silva (4 relatórios).

No que diz respeito aos relatórios de diretores de escolas, a maior parte deles são de diretores de grupos escolares, possivelmente porque o número desse tipo de escola suplantava o de escolas-modelo. Entretanto, o Artigo 57 do Decreto n. 518, de 11 de janeiro de 1898, estabelecia que nos "grupos escolares, actualmente existentes e que de futuro se crearem, será estabelecido o regimen e methodo de ensino das escolas-modelo do Estado". Nesse sentido, ao que tudo indica, os diretores de escolas-modelo e aqueles de grupos escolares deviam obedecer aos mesmos dispositivos legais. Os relatórios de diretores eram remetidos anualmente - antes de 1898 a periodicidade era semestral - ao Secretário dos Negócios do Interior:

Art. 59 - Ao director do grupo escolar compete: $\S 8^{\circ}$. - Elaborar e enviar ao Secretario dos Negocios do Interior (...), findos os trabalhos de cada anno lectivo, um relatorio minucioso sobre o movimento do grupo, mencionando todas as occorrencias que se derem durante o ano e acompanhando-o dos mappas e quadros explicativos necessarios e de todos os subsidios para a estatistica escolar (Decreto n. 518 , de 11 de janeiro de 1898$)^{22}$.

Entre os diretores dos relatórios selecionados, há apenas uma mulher, Eliza R. de Macedo, da escola-modelo "Maria José", autora de dois deles. Além dela, os relatórios do mesmo diretor são de Eduardo José de Camargo, do Grupo Escolar “Dr. Cerqueira César", de Paraibuna, que somam três. De modo geral, os diretores dos dois tipos de escolas, assim como os professores, também citavam a ausência de materiais e de preparo profissional como

\footnotetext{
${ }^{21}$ A "Secretaria de Estado dos Negócios do Interior" - instituída em 1892, através do Decreto n. 28, de 01 de março - foi um dos mais vibrantes órgãos da máquina governamental paulista, representando, ou pretendendo representar, os interesses dos municípios do interior junto ao órgão central. Ao mesmo tempo, ela era também o órgão principal pelo qual o poder estadual centralizava e controlava suas ações políticas (relações com partidos e grupos políticos, com o Congresso Estadual, com as Câmaras Municipais e com os consulados estrangeiros) e sociais (temas ligados à saúde, educação e cultura) em todo o território. Entre 1901 e 1906, passou a cuidar também da justiça e da segurança pública, passando a ser chamada de "Secretaria dos Negócios do Interior e da Justiça" (Tavares, 2004).

22 Nos relatórios coletados, os diretores não mencionam a questão dos mapas e esses tampouco foram encontrados.
} 
fatores que dificultavam a concretização dos programas de ensino. Algo que não foi possível encontrar nos relatórios de professores, contudo, são as justificativas dos diretores para a ênfase dada ao ensino de certas matérias. Assim, o teor dos relatórios de diretores é um pouco mais diversificado do que aquele dos professores, mesmo porque são somente dois os diretores que escreveram mais de um relatório.

No que se refere aos 42 relatórios de inspetores escolares escolhidos, eles, de modo geral, podem ser classificados em três categorias diferentes: os que vêem como necessária a simplificação dos programas de ensino para as escolas isoladas (1899-1911); aqueles que descrevem como vinha sendo desenvolvido o ensino de matérias específicas (1911-1915); e outros preocupados com aspectos que envolvem o nacionalismo, tais como o escotismo e a educação dos caboclos e dos estrangeiros (1917-1918). É necessário acrescentar ainda que, assim como aqueles elaborados pelos professores, alguns desses relatórios são muito semelhantes, quando de mesma autoria.

No conjunto de relatórios, há um que destoa, por ser o único de inspetor de distrito. Nesse caso, ele é referente ao ano de 1896 e dirigido ao "Conselho Superior de Instrução Pública”. De acordo com João Lourenço Rodrigues (Anuários do Ensino do Estado de São

Paulo de 1907-1908, p.XXVII), a partir da Lei n. 88, de 08 de setembro de 1892 - que reforma a Instrução Pública do Estado - a inspeção e a fiscalização do ensino deviam ser de responsabilidade de um Conselho Superior, de um diretor geral servindo como intermediário entre o Conselho Superior e o Governo, e de trinta inspetores de distrito, número que subiu para quarenta em 1895, por meio da Lei n. 347, de 03 de setembro (Tavares, 2004). Com a Lei n. 520, de 26 de agosto de 1897, que extinguiu o Conselho Superior e as inspetorias de distrito, a inspeção e a fiscalização passaram ser atribuições do Inspetor Geral do Ensino ${ }^{23}$, auxiliado por dez inspetores escolares.

As inspeções escolares deviam conciliar as funções de vigilância e controle do trabalho docente, às quais se somaram, posteriormente, argumentos que defendiam cada vez mais a orientação pedagógica dos professores (Catani; Lima, 1997, p.166). Após as visitas, os inspetores escolares - formados, em sua maioria, pela Escola Normal de São Paulo - deviam:

Art. $130 \S 7^{\circ}$. - Apresentar annualmente ao Secretario dos Negocios do Interior um relatorio circumstanciado sobre a marcha do ensino nas localidades que tiver percorrido, indicando os melhoramentos e modificações que julgar convenientes

\footnotetext{
${ }^{23}$ O Decreto n. 1883, de 06 de junho de 1910, remodelou a "Inspetoria Geral do Ensino", denominando-a de "Diretoria Geral da Instrução Pública".
} 
introduzir no regimen escolar e manifestando sua opinião a respeito dos professores (Decreto n. 518, de 11 de janeiro de 1898).

Por fim, os três periódicos educacionais tomados como fontes, quais sejam, a Revista de Ensino (1902-1918), a Revista Escolar (1925-1927) e Educação (1927-1929) podem ser encontrados no acervo de obras raras da Biblioteca da Faculdade de Educação da Universidade de São Paulo, exceto os números referentes ao ano de 1927 da Revista Escolar, disponíveis no "Instituto de Estudos Educacionais Sud Mennucci", do Centro do Professorado Paulista. Ao longo do período delimitado para a pesquisa, foram publicados 64 números da Revista de Ensino, 33 da Revista Escolar e 36 de Educação. Todos os exemplares foram manuseados, tendo sido selecionados, respectivamente, 43, 19 e 16 textos que, de algum modo, tecem referências à questão dos programas de ensino. Entre esses textos, há aqueles transcritos de jornais e revistas, artigos escritos pelos colaboradores e editoriais, como é o caso da Revista Escolar. Sendo a orientação do trabalho docente o objetivo comum entre os três periódicos (Catani, 1998), uma quantidade significativa dos textos escolhidos, especialmente na Revista Escolar e em Educação, versam sobre o ensino das diversas matérias elencadas nos programas de ensino. A relevância desses textos reside no fato de que entremeavam as sugestões aos professores com proclamações sobre a importância dessas matérias, revelando, pois, indícios dos motivos que levaram à sua inclusão nos programas de ensino. Das três publicações consultadas, a Revista de Ensino é a única que questionava as decisões do Estado ligadas ao problema dos programas de ensino, quer fosse a ausência da participação dos professores na elaboração deles, quer fossem os equívocos presentes naqueles em vigor à época.

A potencialidade do estudo dos materiais advindos da imprensa periódica educacional tem sido assinalada por pesquisadores brasileiros e europeus. António Nóvoa (1997, p.13), por exemplo, avalia que os textos veiculados consistem, com freqüência, "numa lógica de reação a acontecimentos ou a idéias, a normas legais ou a situações políticas. A imprensa é, talvez, o melhor meio para compreender as dificuldades de articulação entre a teoria e a prática". No Estado de São Paulo, as primeiras revistas especializadas em educação, dirigidas aos professores, surgiram no final do século XIX, quando se iniciava a organização do sistema público de ensino e do espaço profissional dos professores (Catani, 1998). Entre elas está a Revista de Ensino, que circulou de 1902 a $1919^{24}$ e foi uma iniciativa da

\footnotetext{
${ }^{24}$ O último número da Revista de Ensino é relativo ao período de julho a dezembro de 1918, mas foi publicado em 1919 (Catani, 2003).
} 
“Associação Beneficente do Professorado Público de São Paulo"25. Em 1905, a publicação perdeu a subvenção oficial, retomada em 1911. Nesse intervalo, ela sofreu três interrupções e sua periodicidade passou de mensal para trimestral. Sete anos após o fim da Revista de Ensino, isto é, em janeiro de 1925, foi lançado o primeiro número da Revista Escolar, sob a responsabilidade da Diretoria Geral da Instrução Pública. Saindo mensalmente, o periódico fornecia modelos de lições estruturadas em perguntas e respostas. Em outubro de 1927, um mês após o término da Revista Escolar, foi a vez do lançamento de Educação, fruto de uma fusão entre aquela e a Revista da Sociedade de Educação. A nova publicação, pois, ficou a cargo, inicialmente, da Diretoria Geral da Instrução Pública e da "Sociedade de Educação" de São Paulo. Seu longo ciclo de vida, que vai até 1961, pode ser dividido em três etapas, sendo que a primeira (1927-1930) foi marcada pelo esforço, mensal, de debater temas mais gerais, como os princípios e os fundamentos teóricos da prática escolar (Catani, 2003). De forma geral, os colaboradores dos três periódicos ocupavam posições de destaque na hierarquia do sistema público de ensino paulista (inspetores escolares, professores e ex-alunos da Escola Normal, diretores de escolas, entre outros).

A presente dissertação de mestrado está estruturada em três capítulos. O primeiro, intitulado $\boldsymbol{O}$ novo cenário paulista: crescimento demográfico, expansão urbano-industrial e modernização do ensino, parte da premissa de que a história dos saberes escolares escolhidos para serem transmitidos no ensino primário não pode ser compreendida sem o estudo do contexto histórico no qual a mesma se desenrolou. A seguir, mostra que a criação dos diferentes tipos de escolas primárias e a conseqüente diferenciação dos programas de ensino foram reflexos do processo de modernização educacional organizado pelo poder público paulista. No segundo capítulo, Nacionalizar e moralizar o povo: os programas de ensino prescritos pelo Estado, são identificados, a partir dos programas de ensino publicados entre 1887 e 1929, as matérias e os conteúdos selecionados pelo Estado para cada um dos modelos de escolas primárias. Em seguida, são investigadas as finalidades de alguns desses saberes escolares, reunidas a partir dos relatórios de ensino e dos textos das revistas pedagógicas.

\footnotetext{
${ }^{25}$ Fundada em 27 de janeiro de 1901, foi a primeira associação docente paulista e, "desde o seu início, incluiu no âmbito de suas tarefas e serviços a defesa do grupo profissional, o aprimoramento intelectual, a prestação de serviços de saúde e a assistência financeira em casos de moléstia, invalidez ou necessidade momentânea, além da assistência jurídica" (Catani, 2003, p.43).
} 
Também com base nesses dois materiais, o terceiro capítulo, denominado $\boldsymbol{A}$ interação entre os diversos sujeitos escolares e os programas de ensino divide-se em três partes, todas dedicadas a enfatizar a participação ativa dos diferentes profissionais da educação quando se tratava do debate em torno do que ensinar nas escolas primárias. Já nas Considerações Finais, são retomadas as principais questões assinaladas nos capítulos e sugeridas outras, que poderiam embasar futuras pesquisas. Por fim, os Anexos foram gravados num CD-ROM, afixado ao final do trabalho. 


\section{Capítulo 1 - O novo cenário paulista: crescimento demográfico, expansão urbano-industrial e modernização do ensino}

Sob a inspiração da República norte-americana, a Constituição de 1891 instituiu o princípio do federalismo, que garantia a autonomia dos Estados. Com isso, a organização e a manutenção do ensino primário, do normal e do profissional passaram a ser atribuições estaduais, em continuidade ao que o Ato Adicional de 1834 já previa para as antigas Províncias. O desenvolvimento da educação popular, portanto, dependia fundamentalmente dos recursos econômicos de cada Estado brasileiro. Como centro da vida econômica nacional, o Estado de São Paulo pôde tomar para si o pioneirismo no que se refere à implantação e à expansão do sistema público de ensino primário (Antunha, 1976; Tanuri, 1979). Mas quais foram as implicações de se lidar com essa responsabilidade constitucional num contexto histórico específico? Como era o Estado de São Paulo entre 1887 e 1929, período no qual se desenrolou a história dos programas do ensino primário que a presente pesquisa busca elucidar? Quais foram as necessidades sociais que os programas de ensino procuravam atender e que definiram a seleção dos saberes escolares? O que levou o poder público a diferenciar as escolas primárias e, por conseqüência, os programas de ensino? Com o intuito de responder a tais questões, o capítulo aqui apresentado mostra, primeiramente, as principais mudanças sócio-econômicas sofridas pelo Estado de São Paulo a partir de 1870, destacando, em especial o panorama da capital paulista. As influências dessas circunstâncias históricas de modo particular o anseio de modernização das elites e o crescimento vertiginoso da população - sobre a criação e a disseminação pelo território paulista das escolas-modelo, dos grupos escolares, das escolas isoladas, das escolas-modelo isoladas e das escolas reunidas são o tema da segunda parte do capítulo.

\subsection{O Estado de São Paulo na vanguarda do país}

Das décadas finais do século XIX a 1930, o Brasil ainda podia ser considerado um país agrícola: em 1920, das 9,1 milhões de pessoas em atividade, 6,3 milhões $(69,7 \%)$ 
estavam concentradas no setor da agricultura, 1,5 milhão $(16,5 \%)$ no de $\operatorname{serviços~}^{26}$ e 1,2 milhão (13,8\%) no da indústria (Fausto, 2007, p.281-282). Antes o principal produto de exportação, o açúcar foi superado pelo café em meados do século XIX, deslocando o eixo econômico do país do Nordeste para o Centro-Sul. Em 1887, o Estado de São Paulo já havia assumido a liderança na produção nacional de café, contribuindo com $40 \%$ dela e tornando-o a base da economia paulista. Inicialmente concentrada na região do Vale do Paraíba, a cultura cafeeira expandiu-se para o Oeste Paulista de 1870 em diante (Kowarick, 1994). A crescente demanda pelo café era provocada pelo aumento da população e da renda nos Estados Unidos, principal país consumidor do produto. Por isso, urgia substituir o lento e oneroso processo de transporte do café ao porto de Santos, realizado por tropas de burros (Fausto, 2007). Foi, assim, que os apitos dos trens soaram pela primeira vez em território paulista, anunciando a modernização.

Em 1867, foi inaugurada, pela companhia inglesa "São Paulo Railway Co. Limited", a linha Santos-Jundiaí, que atravessava a Capital. Já a "Companhia Mogiana de Estradas de Ferro" começou a realizar, em 1872, a ligação entre Campinas e Mogi Mirim, logo estendida na direção de localidades como Amparo e Ribeirão Preto (Camargo, 1952). No mesmo ano, pela "Companhia Paulista de Estradas de Ferro", formada por cafeicultores da região de Rio Claro (Love, 1982, p.95), teve início a comunicação Jundiaí-Campinas, prolongada, quatro anos depois, até Rio Claro. Em 1873, a "Companhia Ituana" colocou em operação os primeiros trechos da linha que ia de Jundiaí a Itu. A “Companhia Sorocabana de Estradas de Ferro", por sua vez, em 1875 inaugurou o trecho entre São Paulo e Ipanema, passando por Sorocaba. Por fim, a "Estrada de Ferro São Paulo-Rio de Janeiro", criada no mesmo ano, saía da Estação do Norte, no Brás e a "Estrada de Ferro Araraquense", datada de 1912, ia de Araraquara a São José do Rio Preto (Camargo, 1952). Independentes entre si, todas essas linhas articulavam-se através da Capital, que se tornava, nesse sentido, o nó do sistema ferroviário (Prado Jr., 1971, p.116).

Implantadas nas principais regiões de cultivo do café, as ferrovias reduziram distâncias, introduzindo uma nova percepção do tempo e do espaço, importaram livros e jornais, possibilitaram a abertura de novos cafezais e dinamizaram a economia cafeeira, acelerando o desenvolvimento do interior (Kowarick, 1994; Marcílio, 2005). Com a decadência do Vale do Paraíba e a conseqüente diminuição no número de habitantes - o maior

\footnotetext{
${ }^{26}$ Segundo Fausto (2007, p.282), o termo "serviços" incluem "atividades urbanas de baixa produtividade, como os serviços domésticos remunerados e 'bicos' de vários tipos”.
} 
do Estado até o final do século XIX - para o que contribuía a pouca procura pelos imigrantes, foi a vez do auge de outras zonas ${ }^{27}$, por onde passavam os trilhos dos trens. Uma delas foi a Central, da qual fazem parte municípios servidos pelas companhias de estradas de ferro "Paulista, Sorocabana e Bragantina"28, como Campinas ${ }^{29}$, Jundiaí, Itu, Piracicaba e Sorocaba, com clara tendência para a urbanização ${ }^{30}$ (Camargo, 1952). Nos levantamentos do número de escravos realizados em 1874 e 1881, Campinas assumia a liderança entre todos os outros municípios. Apesar disso, foram exatamente os cafeicultores da Central aqueles que concluíram ser necessária a vinda de estrangeiros para substituir a mão-de-obra escrava, os quais representavam, em 1920, 13\% de sua população total (Love, 1982). Apesar do declínio da lavoura cafeeira, o incremento demográfico foi constante até 1940, face à industrialização de grande quantidade de seus municípios, concomitantemente à veloz urbanização. Outra zona foi a Mogiana, composta por municípios atendidos pela "Companhia Mogiana de Estradas de Ferro". Tendo Ribeirão Preto como centro, ela era, no começo do século XX, a principal produtora de café do Estado e, em 1900, reunia 1/5 da população paulista. Após 1934, porém, à medida em que estagnava a atividade cafeeira, o número de habitantes decaía. Já a Baixa Paulista é formada por municípios que integram o traçado da "Companhia Paulista de Estradas de Ferro" e da "São Paulo-Goiás"31, como Rio Claro, São Carlos e Araraquara. Era uma importante zona agrícola no fim do século XIX e princípio do século XX, possuindo um significativo número de plantações de café. A partir de 1934 e até 1940, sua população decresceu. Foi a primeira região do Estado a receber imigrantes. De 1921 em diante, essas três zonas - entre as mais antigas do Estado - perderam expressividade para outras, denominadas pioneiras, a saber, a Araraquense, a Noroeste e Alta Paulista e a Alta Sorocabana. Juntas, as três já colaboravam, em 1940, com 70\% da produção nacional de café, surto econômico que foi acompanhado de um alto crescimento demográfico, fruto de uma leva de imigrantes que para elas se dirigiu (Camargo, 1952).

\footnotetext{
${ }^{27}$ Adota-se aqui o esquema de divisão do Estado em dez zonas proposto por Camargo (1952): $1^{\mathrm{a}}$. zona - Capital; $2^{\mathrm{a}}$. zona - Vale do Paraíba e Litoral Norte; $3^{\mathrm{a}}$. zona - Central; $4^{\mathrm{a}}$. zona - Mogiana; $5^{\mathrm{a}}$. zona - Baixa Paulista; $6^{\mathrm{a}}$. zona - Araraquense, Douradense e Paulista; $7^{\mathrm{a}}$. zona - Noroeste e Alta Paulista; $8^{\mathrm{a}}$. zona - Alta Sorocabana; $9^{\mathrm{a}}$. zona - Baixa Sorocabana; $10^{\mathrm{a}}$ zona - Santos e Litoral Sul.

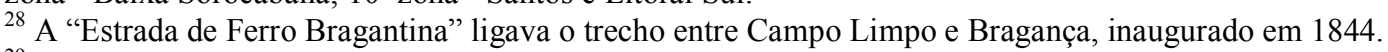

29 Fausto (2007, p.200) explica que a região do Oeste Paulista "não corresponde rigorosamente ao oeste geográfico. Ela abrange a área que vai de Campinas a Rio Claro, São Carlos, Araraquara, Catanduva, na linha férrea que vai da Companhia Paulista; e de Campinas para Piraçununga, Casa Branca e Ribeirão Preto, na Estrada de Ferro Mojiana".

${ }^{30}$ Em 1934, a população rural da região compreendia $67,2 \%$ da total, número que caiu para 59,6\% em 1940 (Camargo, 1952, p.88).

${ }^{31}$ Datada de 1911.
} 
Em determinadas áreas cafeeiras, importantes cidades, como Ribeirão Preto, começaram a surgir. Sob a liderança dos fazendeiros Francisco Schmidt, que recebeu o título mundial de rei do café, e de Joaquim da Cunha Diniz Junqueira, os habitantes de Ribeirão Preto, município criado em 1871 (Camargo, 1952, p.28), assistiram a um processo de urbanização, entre 1890 e 1920, que a tornou conhecida como a "Petit Paris da Zona Mogiana”. Referenciada pela remodelação urbana de Paris comandada pelo barão de Haussmann $^{32}$, a elite cafeeira da região procurou saciar seus ímpetos de modernização através de melhoramentos urbanos como a instalação da rede de eletricidade, em 1899, além do calçamento de ruas e da construção de edifícios públicos como o Teatro Carlos Gomes, em 1897, o então segundo maior do país (Paziani, 2005). Em 1913, havia na cidade seis jornais e mais de dezessete clubes e sociedades com fins variados (Love, 1982, p.120). Os numerosos italianos, portugueses e espanhóis que habitavam a cidade - a população urbana, em 1912, era estimada em 17.599 pessoas $^{33}$ - dedicavam-se a diversas ocupações urbanas, de que eram exemplos a indústria (massas, cerveja, entre outros produtos), a construção civil, os cinemas e o comércio, cujos nomes de alguns estabelecimentos - "Au Louvre", "Notre Dame de Paris", "Au Bon Marche" - evidenciavam qual a capital européia tomada como modelo. Além dos imigrantes e de migrantes de outros Estados, principalmente mineiros, fluminenses e baianos, desembarcavam em Ribeirão Preto personalidades ilustres, fossem elas estrangeiras ou brasileiras, tais como políticos, escritores e artistas, ou mesmo simples viajantes, todos curiosos em conhecer os progressos da $\operatorname{cidade}^{34}$ (Paziani, 2005).

\footnotetext{
${ }^{32}$ O engenheiro e urbanista Pereira Passos - a quem Rodrigues Alves confiou a reforma urbana da cidade do Rio de Janeiro após sua posse na presidência, em 1902 - acompanhou de perto os planos de Haussmann, a ponto de ter sido fortemente inspirado por esse. Levados a efeito de 1853 a 1870, eles consistiram, especialmente, na abertura de amplas avenidas e bulevares, que impedissem a formação de barricadas no transcorrer de revoltas populares, bem como na derrubada de moradias populares consideradas inadequadas pelo governo de Napoleão III (Sevcenko, 1984; Marins, 2004).

${ }^{33}$ No mesmo ano, 1.012 pessoas moravam nas zonas suburbanas do município e 36.949 nas zonas rurais (Paziani, 2005). Vale registrar ainda que a região Mogiana concentrou, de 1901 a 1940, o segundo maior número de imigrantes e migrantes que se dirigiram ao Estado de São Paulo. Ademais, ela detinha, em 1940, o maior contingente de negros e pardos do Estado (Love, 1982, p.47).

${ }^{34}$ Pouco atingidas pelos benefícios da cidade moderna, as camadas populares de Ribeirão Preto interagiram a seu modo com as mudanças sofridas por ela: exigindo "melhoramentos urbanos; participando no competitivo mercado; expressando no cotidiano suas visões críticas da cidade (como vítimas e/ou protagonistas das novas situações); reivindicando melhores condições de trabalho ou ainda ironizando os hábitos nada civilizados da elite ribeirão-pretana" (Paziani, 2005, p.200).
} 


\subsubsection{Retrato de uma cidade em rápida mudança: São Paulo e a modernização}

Em nenhuma outra zona do Estado de São Paulo, todavia, o café engendrou tantas e tão intensas transformações quanto na Capital. A partir de 1870, o tempo em que a simplicidade e o marasmo que marcavam o cotidiano da então pouco habitada cidade eram interrompidos apenas pela agitação de entediados estudantes da Academia de Direito ${ }^{35}$ já pertencia a um passado remoto. Novos habitantes, vindos dos mais diversos lugares, chegavam à futura metrópole, contribuindo para edificá-la. Era o caso dos imigrantes: como assinala Prado Jr. (1971, p.122), quem "procura compreender São Paulo não pode esquecer este aspecto da questão; tanto mais importante que sem aquelas fortes correntes imigratórias, a cidade não seria certamente o que é, e o São Paulo que aqui procuro desenvolver não existiria". Entre 1820 e 1949, dos 4,8 milhões de estrangeiros recebidos pelo Brasil ${ }^{36}, 2,5$ milhões dirigiram-se para São Paulo (Hall, 2004a, p.121) - o Estado que mais acolheu imigrantes (Marcílio, 2005, p.95) - muitos deles para trabalhar no campo, findo o sistema escravista. Em virtude disso, em 1890, sua participação na população total do país já era de $10 \%$, representando o terceiro estado mais populoso, atrás apenas de Minas Gerais e da Bahia. A importação de mão-de-obra - européia, numa fase inicial e japonesa a partir de 1908 - foi custeada pelo governo da Província de São Paulo a partir de 1885 (Kowarick, 1994, p.83). A tabela a seguir indica o número de estrangeiros que entraram no Estado de São Paulo de 1885 a $1929^{37}$, segundo a nacionalidade:

TABELA 1

\begin{tabular}{|c|c|c|c|c|c|c|c|}
\hline Período & Italianos & Portugueses & Espanhóis & Japoneses & Diversos & $\begin{array}{c}\text { Não } \\
\text { Especificados }\end{array}$ & Total \\
\hline $\begin{array}{c}1885- \\
1889\end{array}$ & 137.367 & 18.486 & 4.843 & - & 6.968 & - & 167.644 \\
\hline $\begin{array}{c}1890- \\
1894\end{array}$ & 210.910 & 30.752 & 42.316 & - & 20.899 & 14.855 & 319.732 \\
\hline $\begin{array}{c}1895- \\
1899\end{array}$ & 219.333 & 28.259 & 44.678 & - & 11.305 & 111.678 & 415.253 \\
\hline $\begin{array}{c}1900- \\
1904\end{array}$ & 111.039 & 18.530 & 18.842 & - & 11.191 & 11.693 & 171.295 \\
\hline $\begin{array}{c}1905- \\
1909\end{array}$ & 65.595 & 38.567 & 69.682 & - & 825 & 23.870 & 196.539 \\
\hline
\end{tabular}

35 Fundada em 1827. Para alguns contemporâneos, foi “justamente o caráter pacato da cidade nas primeiras décadas do século XIX" (Cruz, 2000, p.49-50) que determinou sua escolha para a instalação da Academia.

${ }^{36}$ Outros países receptores de imigração em massa foram a Argentina, o Canadá e os Estados Unidos (Fausto, 2007, p.275).

${ }^{37}$ Em alguns anos, o saldo de entrada e saída de imigrantes foi negativo. Em 1900, por exemplo, embora tivessem chegado ao Brasil 21.038 pessoas, 21.917 retornaram ao seu país (Fausto, 2007, p.280). 


\begin{tabular}{|c|c|c|c|c|c|c|c|}
\hline $\begin{array}{c}1910- \\
1914\end{array}$ & 88.692 & 111.491 & 108.154 & 14.465 & 40.096 & - & 362.898 \\
\hline $\begin{array}{c}1915- \\
1919\end{array}$ & 17.142 & 21.191 & 27.172 & 12.649 & 5.530 & - & 83.684 \\
\hline $\begin{array}{c}1920- \\
1924\end{array}$ & 45.306 & 48.200 & 36.502 & 6.591 & 60.713 & - & 197.312 \\
\hline $\begin{array}{c}1925- \\
1929\end{array}$ & 29.472 & 65.166 & 27.312 & 50.573 & 117.418 & - & 289.941 \\
\hline
\end{tabular}

Fonte: São Paulo (Estado). Secretaria da Agricultura. Departamento de Imigração e Colonização. Estatística dos trabalhos executados pelo Departamento de Imigração e colonização durante o ano de 1961. São Paulo, 1962, p. $44^{38}$

Assim que desembarcavam no porto de Santos, os estrangeiros - vindos em famílias, em sua maioria (Love, 1982, p.28) - eram levados à Hospedaria dos Imigrantes (1888), próxima à Estação do Norte, e de lá seguiam ao interior. Não obstante, as duras normas impostas pelos cafeicultores aos imigrantes - eles eram obrigados, por exemplo, a comprar seus produtos nos armazéns das próprias fazendas (Kowarick, 1994, p.80) - fizeram com que muitos abandonassem o campo em direção à Capital. Além disso, São Paulo recebia aqueles que a ela vinham espontaneamente, sem passar pela experiência nas lavouras, como os judeus e os sírio-libaneses. Dessa forma, o crescimento demográfico da cidade foi vertiginoso, conforme a tabela abaixo:

TABELA 2

\begin{tabular}{|c|c|c|c|}
\hline$A N O$ & $\begin{array}{c}\text { POPULAÇÃO } \\
\text { (cidade de São } \\
\text { Paulo) }\end{array}$ & $\begin{array}{c}\text { POPULAÇÃO } \\
\begin{array}{c}\text { Estado de São } \\
\text { Paulo) }\end{array}\end{array}$ & $\begin{array}{c}\text { POPULAÇÃO } \\
\text { (Brasil) }\end{array}$ \\
\hline 1872 & 31.385 & 837.354 & 10.112 .061 \\
\hline 1890 & 64.934 & 1.384 .753 & 14.333 .915 \\
\hline 1900 & 239.820 & 2.282 .279 & 17.318 .556 \\
\hline 1920 & 579.033 & 4.592.188 & 30.635 .605 \\
\hline 1940 & 1.326 .261 & 7.180 .316 & 41.236 .315 \\
\hline
\end{tabular}

Fonte: IBGE, Censos Demográficos ${ }^{39}$

Em apenas uma década (1890-1900), o índice de crescimento da cidade foi de 13,9\%, superior ao do Estado de São Paulo, de 5,1\% (Marcílio, 2005, p.95). Com isso, ela tornou-se a quarta cidade mais populosa do país, perdendo apenas para o Rio de Janeiro, Salvador e Recife. À guisa de comparação, em 1872, São Paulo era ultrapassada pelo Rio de Janeiro, Salvador, Recife, Belém, São Luís, Fortaleza, Niterói, Porto Alegre e Cuiabá (Saes, 2004).

\footnotetext{
${ }^{38}$ Apud http://www.memorialdoimigrante.org.br.

${ }^{39}$ Apud http://sempla.prefeitura.sp.gov.br/historico.
} 
Ainda nesse ano, 2.459 estrangeiros residiam na cidade, número que subiu para $14.303 \mathrm{em}$ 1890 e para 206.657 em $1920^{40}$. Além disso, se em 1893, os italianos formavam $34 \%$ da população da Capital, no início do século XX, eles já constituíam 50\%. A presença majoritária dos italianos perdurou até 1940, quando foram superados pelos portugueses, que somavam 78.949 dos habitantes. Na posição de terceiro maior contingente de imigrantes, ao menos até 1940, vinham os espanhóis, que representavam 35.136 dos moradores. O restante da população estrangeira era composto, entre outros, por sírio-libaneses, húngaros, judeus, japoneses e armênios (Hall, 2004a).

$\mathrm{O}$ intenso movimento imigratório acelerou o processo de urbanização e de industrialização da Capital. No primeiro caso, como afirma Prado Jr. (1971, p.132), São Paulo deixava de ser

uma cidade descontínua, em que se alternam, num caos completo, aspectos de grande centro urbano, modesto povoado de roça, ou mesmo zona de sertão. O progresso da cidade vai naturalmente suprimindo tudo isto, e a urbanização vence, aos poucos, aqueles obstáculos naturais e outras dificuldades que o crescimento fulminante da cidade não teve tempo de abater, preferindo contorná-los e deixá-los provisoriamente entregues à sua feição natural.

A cidade que vivia simultaneamente vários tempos, portanto, crescia fisicamente, ocupando cada vez mais espaços antes agrários e se tornando, conseqüentemente, um grande centro urbano e moderno (Glezer, 2007, p.183). Foi na gestão de João Teodoro como presidente da Província (1872-1875) que alguns melhoramentos urbanos começaram a modificar o dia-a-dia de São Paulo: a reforma do Jardim da Luz; a abertura da Rua Sete de Abril; a substituição dos antigos lampiões pela iluminação a gás, fornecida pela empresa inglesa "The São Paulo Gas Company"; a implantação de bondes de tração animal que, em 1887, irradiando do centro, atingiam os bairros da Liberdade, Mooca, Brás, Luz, Santa Cecília e Consolação; o início, em 1877, da captação de água e esgoto, pela "Companhia Cantareira de Água e Esgotos", assim como a distribuição da primeira; a instalação, em 1883, do serviço telefônico (Saes, 2004, p.217; Segawa, 2004, p.344-345; Souza, M., 2004, p.526).

O estímulo dos estrangeiros à industrialização, por sua vez, ocorreu por variadas formas. Primeiramente, até cerca de 1920, os imigrantes representavam 52\% do proletariado, sendo que os 48\% restantes eram filhos de estrangeiros (Kowarick, 1994, p.93). Com efeito, em 1912, uma pesquisa em 30 fábricas têxteis apontou que, dos mais de 9 mil operários, 80\% era formado por imigrantes (Hall, 2004b, p.260). Entre eles, os italianos eram os mais numerosos, seguidos pelos portugueses e pelos espanhóis (Hall, 2004a). Nos demais setores

\footnotetext{
${ }^{40}$ Apud http://www.memorialdoimigrante.org.br.
} 
da indústria, a proporção era análoga (Kowarick, 1994, p.93). Em segundo lugar, de origem social mais privilegiada do que a dos seus conterrâneos que vieram para o Brasil, alguns estrangeiros adquiriram suas próprias fábricas, como o italiano Francisco Matarazzo e os irmãos Jafet, de nacionalidade sírio-libanesa ${ }^{41}$. Por fim, o fluxo imigratório propiciou o surgimento do mercado interno, o qual demandava o fornecimento de mercadorias, algumas até então inéditas, em virtude da introdução de diferentes hábitos de consumo.

O elemento fundamental que possibilitou o início do desenvolvimento industrial em São Paulo, no entanto, foi o acúmulo de capital proveniente das exportações de café. A escolha da cidade para a concentração de estabelecimentos fabris deveu-se à facilidade de comunicação com os mercados consumidores - o Estado e suas proximidades - e com o porto de Santos, através do qual se atendiam outros mercados nacionais e se importavam matériaprima e equipamentos (Prado Jr., 1971, p.110). Não à toa, as indústrias foram instaladas ao redor das ferrovias. À época da proclamação da República, havia poucas fábricas, embora fossem inúmeras as oficinas artesanais, ocupadas por sapateiros, alfaiates, marceneiros, ferreiros, entre outros (Saes, 2004, p.218). São Paulo era, em suma, uma cidade de serviços, e não uma cidade industrial (Glezer, 2007, p.183). A partir da primeira década republicana, entretanto, novas fábricas, de porte significativo, surgiram na Capital. Entre elas, estavam aquelas que produziam peças de vestuário (roupas, chapéus, calçados); bebidas, como cerveja; materiais de construção; produtos químicos (Saes, 2004, p.224-225). Referindo-se ao ano de 1902, Americano ${ }^{42}$ (2004, p.97-98) fornece informações sobre os bairros em que se concentravam as primeiras fábricas, interpretadas como "uma benção e um sinal de progresso" (Morse, 1970, p.295) da cidade:

\footnotetext{
${ }^{41}$ Matarazzo fundou, entre outras, fábricas de sacaria, de tecidos algodão, de sabão e sabonetes, de massas alimentícias e de biscoitos. A família Jafet instalou, no bairro do Ipiranga, a empresa "Fiação, Tecelagem e Estamparia Ipiranga Jafet S.A.” (Saes, 2004).

42 Jorge Americano, nascido em 25 de agosto de 1891, fez o curso primário na Escola-Modelo "Caetano de Campos" (1898-1902) e o secundário no "Ginásio São Bento" (1903-1907). Formou-se pela Academia de Direito de São Paulo e foi reitor da Universidade de São Paulo de 1941 a 1946. Em 1957, foi publicado São Paulo naquele tempo (1895-1915), seu primeiro volume de uma trilogia de memórias sobre a cidade de São Paulo. A relevância do uso das obras memorialísticas como fonte para estudos sobre História da Educação tem sido realçada por autores como Viñao Frago (2000, p.90-91): "permiten, por ejemplo, reconstruir (...) la cultura escolar, en especial lo relativo a los espacios y tiempos escolares; la percepción que los profesores y maestros tenían de si mismos, en cuanto grupo social y profesional y la los alumnos tenían de ellos; el mundo de la alfabetización y las lecturas, etc. - en los que las autobiografias memorias y diarios pueden ser utilizadas no sólo para contrastar los discursos, las propuestas teórico-normativas y la legalidad con la realidad y prácticas educativas y escolares - o, al menos, con la vivencia que se tenía de las mismas, es decir, con como fueron vividas -, sino también para ofrecer un número de testimonios suficientemente amplio como para poder extraer de ellos similaridades generales y mostrar, al mismo tiempo, la inagotable diversidad de las vivencias particulares".
} 
Nascia a cidade industrial. Do viaduto do Chá, viam-se os bairros industriais do Bom Retiro e Luz. Do pátio em frente à Igreja do Carmo na esquina da rua com a Ladeira do Carmo, via-se todo o restante, Brás e Mooca. Não é que tudo fosse muito grande. (...) Mas os quatro bairros industriais (Bom Retiro, Luz, Brás e Mooca) continham toda a indústria paulista: tecidos de juta para sacaria e tecidos de algodãozinho; serrarias e fábricas de móveis; refinações de açúcar; torrações de café; fábricas de botões de ossos; fábricas de telhas, olaria e cerâmica; louças de mesa chamadas de 'pó de pedra'. Indústrias rudimentares, de couros e mais algumas coisas. Seriam trinta ou quarenta chaminés, de fumaça negra de coque da Inglaterra (ainda não havia eletricidade em São Paulo). Os paulistas falavam disso orgulhosamente: 'Manchester brasileira!'

De 1920 em diante, outros ramos fabris, mais complexos, passaram a oferecer não mais bens de consumo imediatos, mas sim duráveis, tais como papel, aço, máquinas agrícolas e automóveis. Para além da sua expansão urbano-industrial, São Paulo tornava-se também, cada vez mais, um centro financeiro e comercial. Diversos bancos, nacionais ou estrangeiros, tinham sua sede ou agências na Capital, como o "Banco do Comércio e Indústria de São Paulo", um dos mais importantes do primeiro período republicano e entre cujos sócios estavam membros da elite paulista (Saes, 2004). No que diz respeito ao comércio, além do ambulante, realizado, especialmente, por sírio-libaneses e judeus (Hall, 2004a), nos anos de 1890 já havia uma quantidade expressiva de pequenos estabelecimentos, destinados a uma clientela de baixa renda. Por outro lado, nas décadas iniciais do século XX, era o chamado Triângulo - formado pelas ruas XV de Novembro, São Bento e Direita, no centro da cidade que reunia o comércio de luxo. Lojas como a "Mappin", de origem inglesa, e sua concorrente, a "Casa Alemã", importavam mercadorias para satisfazer as camadas mais ricas da população, tornando explícita a desigual distribuição da riqueza na cidade (Saes, 2004).

Além dos imigrantes, a cidade ainda atraiu os fazendeiros de café que, com a renda acumulada, procuraram diversificar seus investimentos, atuando em outros setores, tais como o comércio e as finanças. Para assumirem seu papel de empresários urbanos (Saes, 2004, p.240), eles migravam ${ }^{43}$ com suas famílias para a Capital, onde residiam em imponentes

\footnotetext{
${ }^{43}$ Outros migrantes nacionais vieram para a Capital, mas se inseriram em posições sociais mais privilegiadas que aquelas às quais pertenciam uma avultada parcela da população paulistana: eram indivíduos que exerciam, em zonas agrícolas decadentes, ocupações geradas pela urbanização dessas, tais como a de artesão, vendedor, escrituário, funcionário público e pequeno negociante. Havia ainda aqueles que, sendo membros de empobrecidas famílias de cafeicultores, passaram a exercer na cidade o magistério, por exemplo. Tratava-se, pois, de uma migração seletiva, tendo em vista que, embora também provenientes do interior do Estado e de outras regiões do país, eram brasileiros que se diferenciavam dos trabalhadores rurais por estarem qualificados para as variadas oportunidades abertas pela urbanização e industrialização da Capital (Martins, 2004b).
} 
palacetes construídos no bairro de Campos Elíseos, como foi denominado a partir de 1878, e nos terrenos altos e salubres de Higienópolis, que começou a tomar forma em 1893, e da Avenida Paulista, inaugurada em $1891 \mathrm{em}$ plena área campestre - o que denotava que o processo de transição do mundo rural para o urbano ainda não estava completo (Segawa, 2004). Antonio da Silva Prado, pertencente à mais relevante e representativa família do ciclo cafeeiro (Berriel, 2003, p.83), simbolizou a metamorfose dos grandes proprietários rurais em empreendedores capitalistas. Ex-ministro do Império e um dos criadores da "Sociedade Promotora de Imigração" - responsável pela vinda dos trabalhadores para o campo - Prado trabalhou, por exemplo, como acionista e presidente do "Banco do Comércio e Indústria de São Paulo", cargo que exerceu também na "Companhia Paulista de Estradas de Ferro" e fundou a "Casa Prado Chaves \& Cia", empresa exportadora de café e a "Vidraria Santa Marina”, que fabricava garrafas para cervejarias como a "Antarctica” (Berriel, 2003; Martins, 2004, p.184-185; Saes, 2004, p.241). Foi durante sua administração como prefeito da cidade (1899-1910) que a empresa canadense "The São Paulo Light and Power Company Limited" estabeleceu um marco na modernização da infra-estrutura urbana. Presente em São Paulo desde 1899 para concorrer com a "Companhia Viação Paulista", que operava linhas de bondes puxados a burros, a "Light" rapidamente tornou-se vitoriosa, passando a realizar o transporte público, mas agora por bondes elétricos (Saes, 2004, p.226). Em maio de 1900, foi inaugurada a primeira linha, que fazia o trecho Largo São Bento-Barra Funda (Queiroz, 2004, p.25). Logo após, a "Light" também monopolizou o fornecimento de energia elétrica, absorvendo a “Companhia Água e Luz”, que atendia residências e indústrias, e a "The São Paulo Gas Company", que fazia a iluminação pública ${ }^{44}$.

Prado também realizou importantes intervenções urbanísticas, tais como a abertura das avenidas Tiradentes e Angélica, o ajardinamento do Museu do Ipiranga, a remodelação da praça que hoje leva seu nome e a melhoria do Largo do Paissandu (Queiroz, 2004, p.25; Segawa, 2004, p.372) e a inauguração, em 1892, do Viaduto do Chá, "projetado e construído por Jules Martin, francês radicado em São Paulo. Com estrutura metálica sobre sapatas de alvenaria, assentadas nos terrenos da Baronesa de Itapetininga" (Americano, 2004, p.113). Além disso, em 1901, onde antes havia uma modesta estação ferroviária, datada de 1867, foi erguido o majestoso edifício da Estação da Luz, inspirado na arquitetura inglesa e que alterou definitivamente o padrão arquitetônico vigente. Com efeito, na materialização do novo

\footnotetext{
${ }^{44}$ Em 1916, a "Light" uniu numa única empresa, a "The Rio de Janeiro and São Paulo Telephone Company”, o sistema telefônico das duas cidades. Nesse sentido, à exceção da água e do esgoto, sob os cuidados do governo do Estado, a "Light" era a responsável pelos serviços coletivos urbanos da Capital (Saes, 2004).
} 
desenho urbano idealizado por Prado, as antigas casas de taipa da época colonial e imperial desapareciam, cedendo lugar ao ferro e ao tijolo, material que propiciaria "o paramento conveniente para a imagem arquitetônica desejável de urbe progressista e civilizada" (Segawa, 2004, p.367). Por sua vez, a utilização do estilo neoclássico - trazido por artífices italianos e presente tanto nos casarões dos cafeicultores quanto nas obras públicas evidenciava a intenção da elite dirigente representada por ele de imprimir à cidade a tão sonhada feição européia (Queiroz, 2004, p.22). Exemplo disso foi o Teatro Municipal, uma cópia da Ópera de Paris (Souza, M., 2004, p.533) que Prado, ao constatar a ausência de vida social em São Paulo (Segawa, 2004, p.372), encomendou ao arquiteto brasileiro Francisco de Paula Ramos de Azevedo. Americano (2004, p.284, grifos meus) relembra o selecionado público que compareceu à sua noite de estréia, em 1911:

No segundo intervalo, passeava-se no 'foyer'. Os homens, de cartola na cabeça, embora dentro de casa. Os que tinham claque (chapéu de molas londrino, que se achatava, e em cujas dobras se apertavam as luvas), esses traziam-no debaixo do braço. Tudo como em Londres ou Paris, vejam-se os quadros de Renoir, do fim do século.

Assim como os homens, as mulheres de posição social mais elevada exibiam figurinos que "vinham da França e traziam mudanças radicais a cada seis meses" (Americano, 2004, p.263). A estreita relação entre a Europa e a elite enriquecida pelo café, todavia, extrapolava a questão da arquitetura e dos trajes: "Toda gente fina ia à Europa, de março ou abril a setembro" (Americano, 2004, p.209). Além disso, entre eles era comum falar francês, ler novelas inglesas e revistas francesas, bem como contratar preceptoras, amas e pagens alemãs, francesas e belgas (Queiroz, 2004, p.37; Martins, 2004, p.191). Isso porque, em sua vida citadina, os fazendeiros tornavam-se, de certa forma, também estrangeiros, ou seja, a cultura, a mentalidade, os hábitos, os costumes, os valores e as referências por eles adotados eram marcadamente europeizados. No entender de Martins (2004b, p.209), contudo, não "havia fingimento nem imitação gratuita nisso tudo. Essa era a crua realidade das relações econômicas geradas pela agricultura de exportação. Não se pode exportar sem importar, vender sem comprar". Aqueles que ostentavam poder e dinheiro, pois, tinham sua atenção voltada somente para a Europa, sobretudo para a França, como bem ilustra Americano (2004, p.357):

(...) quem foi Thiers, quem foi Sady Carnot, quem foi Jules Grévy, quem é Loubet, toda gente sabe. Quem é Sarah Bernhardt, quem é Rejane, quem é Flaubert, Victor Hugo, Maupassant, Zola, toda gente sabe. E Condorcet e Claude Bernard e Pasteur...

Alguém será capaz de dizer de repente uma lista destas, em relação a qualquer outro país? 
Foi também espelhando-se na Europa que os cafeicultores e suas famílias - que antes de migrarem para a Capital deixavam as fazendas apenas para ocasiões religiosas contribuíram para forjar novos espaços de sociabilidade e de lazer (Rago, 2004, p.392). Além das apresentações teatrais, eles e outros grupos sociais de mesmo nível econômico freqüentavam, por exemplo, as denominadas "garden-parties", como explica Americano (2004, p.278, grifos meus):

(...) para celebrar o sábado de Aleluia, como pelo simples gosto de dançar ao ar livre numa tarde de maio ou setembro de dias lindos, organizava-se o garden-party 'como em Londres'. (...) os organizadores não tinham objetivo filantrópico, nem fito de lucro. Era gente de boa sociedade, que organizava uma dança ao ar livre.

Havia ainda outro momento em que os abonados da cidade encontravam seus pares, segundo Americano (2004, p.280, grifos meus):

'Como em Nice', tivemos batalhas de flores. Era tudo em landôs, e vitórias abertas, ou automóveis de capota arreada. (...) Enchia-se de moças e rapazes, e as indispensáveis mães (...). Dentro de cada carro, cestos de flores, e, seguindo o corso em quatro linhas entrecruzadas, toda vez que encontravam conhecidos, atiravam flores, acompanhadas de sorrisos e cumprimentos.

A Villa Kyrial - situada no bairro da Vila Mariana e onde residia o senador e mecenas José de Freitas Valle (Rago, 2004, p.406) - também funcionou como uma significativa experiência social e cultural para aqueles pertencentes à elite. Inspirados na aristocracia francesa, os sofisticados salões nela promovidos eram restritos a "três grupos que de certo modo se entrelaçavam. O dos políticos, o dos artistas e os amigos dos filhos" (Americano, 2004, p.292). Nomes como Mario de Andrade, Oswald de Andrade, Tarsila do Amaral, Anita Malfatti, Washington Luís e Bernardino de Campos reuniam-se para participar de banquetes, palestras literárias, recitações de poesias, audições musicais e partidas de pingue-pongue (Americano, 2004, p.292; Rago, 2004, p.405-407). Também em determinados esportes vistos pelas parcelas privilegiadas da população que neles competiam como meio de liberação do corpo e de inserção na modernidade (Rago, 2004, p.392) - foi forte a influência européia. O golfe, por exemplo, começou por volta de "1905, pelos ingleses aqui estabelecidos, gente do London Bank, do River Plate Bank, do British Bank, da Casa Nathan, e alguns mais" (Americano, 2004, p.300). 
Claro está que o intenso ritmo do processo de urbanização e de modernização da Capital engendrou um profundo quadro de segregação sócio-espacial. Enquanto a parte enriquecida da população residia em luxuosas mansões, andava em automóveis, consumia produtos estrangeiros, freqüentava reservados círculos sociais e culturais, em suma, tentava converter a cidade numa extensão de Paris ou Londres, vastas camadas sociais mais desfavorecidas foram postas à margem do progresso. $\mathrm{O}$ projeto de construção de uma cidade que permitisse a inserção do país no mundo dito civilizado tratou, ao contrário, de desqualificar, sempre que possível, o modo de vida dos sujeitos populares, fosse no espaço público, fosse no espaço privado. Exemplo disso, no que tange ao primeiro caso, foi o ocorrido com a Várzea do Carmo, ponto de encontro de uma significativa parcela pobre da população nacional, em especial das "lavadeiras", muitas delas ex-escravas. Taxados pelas autoridades municipais como promíscuos, vadios, indecentes e criminosos, os ocupantes da região insubordinavam-se, pois, aos códigos de comportamento europeizados que se procurava consolidar na cidade, colocando em risco a almejada ordem pública. Por isso, o então prefeito da cidade, Washington Luís (1914-1919), estabeleceu um novo uso para a Várzea, criando nela um parque ${ }^{45}$ belo, asseado, moralizado, seguro e civilizado (Santos, $2003)^{46}$.

Outro reduto de concentração dos nacionais despossuídos (Santos, 2003) era a Igreja Nossa Senhora do Rosário dos Homens Pretos, no Largo do Rosário, que fazia frente para a Rua XV de Novembro (Americano, 2004, p.121). Ao redor da Igreja, após as procissões religiosas, os afro-descendentes ${ }^{47}$ realizavam congadas, batuques, sambas, moçambiques e

\footnotetext{
${ }^{45}$ Inaugurado em 1922.

${ }^{46}$ Americano (2004, p.131, grifos meus) mostra com riqueza de detalhes como era o trabalho das "lavadeiras" no local antes dele ser transformado no atual Parque D. Pedro II: "Da Rua Glicério e de toda a encosta da colina central da cidade, desciam lavadeiras de tamancos, trazendo trouxas e tábuas de bater roupa. À beira d' água, juntavam a parte traseira à dianteira da saia, por um nó apanhado da saia, a qual tomava aspecto de bombacha. Sungavam-na pela parte superior, amarravam-na à cintura com barbante, de modo a encurtá-la até os joelhos ou pouco acima, tomando agora o aspecto de calção estofado. Deixavam os tamancos, entravam n' água e debruçavam-se sobre o rio, sem perigo de serem mal-vistas pelas costas. Terminada a lavagem, recompunham o vestuário, calçavam os tamancos e subiam a encosta. Isso durou até que o poder público resolveu aterrar e ajardinar a Várzea do Carmo".

47 Os dados calculados por Santos (2003, p.39) para o período de 1890 a 1893 mostram que, embora a participação de negros, caboclos e mestiços na população da cidade tenha diminuído percentualmente, houve um crescimento no total de indivíduos classificados como tais: de 11.730 para 15.049 . O que os impelia para a Capital era a possibilidade de nela encontrar "comunidades preexistentes, relativamente estáveis, capazes de estabelecer liames com as experiências anteriores e fornecer os sentidos que buscavam para sua reorganização social" (Wissenbach, 2006, p.99-100). Esses denominados "territórios negros" estavam espalhados em bairros como Barra Funda, Cambuci e Bexiga. Nesse último, os primeiros moradores tiveram de compartilhar as habitações com os recém-chegados imigrantes, principalmente italianos (Wissenbach, 2006). Preteridos pelo comércio e pela indústria - as áreas mais dinâmicas da economia - aos homens negros restavam ocupações como a de carroceiro, cocheiro, lavador de casas, varredor de ruas, tratador de animais, carregador, limpador de trilho, coletor de lixo e, às mulheres, a de quitandeira, ambulante (tabuleiros de doces), ama-de-leite, cozinheira,
} 
caiapós, celebrações de origem africana e indígena. Não obstante, tais manifestações culturais representavam, aos olhos da municipalidade, resquícios do passado que se desejava apagar da memória da cidade, sobretudo porque eram tornadas públicas em pleno Triângulo Central, considerado um símbolo da europeização paulistana ao reunir bancos, casas comerciais, confeitarias, cafés, restaurantes e hotéis (Santos, 2003). Apesar de reagirem contra a ação governamental, os membros da Irmandade de Nossa Senhora do Rosário dos Homens Pretos perderam sua Igreja, demolida em 1904 para o alargamento da europeizada Praça Antonio Prado e reconstruída em 1906 no Largo do Paissandu (Rago, 2004, p.390).

Esse processo de reorganização dos espaços públicos através do silenciamento, da exclusão e até mesmo da extinção do que e de quem eram vistos como indesejáveis (Santos, 2003) pode ser melhor compreendido quando se leva em conta a preocupação dos donos do poder com a imagem aterrorizante de uma cidade sendo invadida por "novos bárbaros" (Rago, 1997, p.11). De fato, se à época da escravatura, as ruas eram ocupadas por negros, mulatos e caipiras, com as mudanças sofridas por São Paulo a partir de 1870, elas passaram a ser tomadas por pessoas de diferentes nacionalidades e origens sociais (Martins, 2004, p.198). Até mesmo os membros das elites, habituados a incumbir seus escravos de sair às ruas em busca de mercadorias, começaram a deixar a privacidade de suas casas. Essa nova prática citadina incluía também as mulheres, embora nelas ainda pesasse um rígido controle moral e social (Rago, 2004, p.393) ${ }^{48}$. Para garantir que tais segmentos sociais circulassem tranqüilamente pelas ruas, os responsáveis pela administração pública recorreram também à polícia. A atuação dessa, porém, foi pautada não pela sutileza disciplinadora, e sim pela brutalidade repressiva. Como a arbitrariedade era a regra, o resultado foi um alto número de detenções, maior do que o de processos. Nos registros policiais, uma das categorias de infrações era a "desordem", na qual predominavam os estrangeiros e entre os quais estavam desde embriagados e briguentos até anarquistas, socialistas, feministas e grevistas. Aqueles presos como "vadios", por sua vez, eram, em sua maioria, nacionais (Patto, 1999). Além dos negros praticantes da capoeira, do candomblé, do curandeirismo e da feitiçaria terem sido enquadrados como tais (Wissenbach, 2006, p.127), também o foram os "pobres livres" obrigados a criar cotidianamente dolorosas estratégias de sobrevivência, envolvendo-se não

copeira, passadeira, faxineira, criada. Apesar de serem serviços socialmente desqualificados, praticamente todos eles eram fundamentais para o funcionamento da cidade moderna (Santos, 2003).

${ }^{48}$ Americano (2004, p.76) atesta que, no início do século XIX, uma moça "jamais podia sair de casa sozinha, para o centro da cidade. Tinha que ir acompanhada pela mãe, ou por irmão ou irmã, mesmo pequenos; ou por um sobrinho. Também a mãe não podia sair de casa sozinha. Tinha que ir acompanhada pela filha ou neto". 
apenas com trabalhos sem valor social, mas ainda com a mendicância, a prostituição, o jogo e o roubo (Patto, 1999).

Se foram tolhidas as práticas populares de vida mantidas na esfera pública, no que se referia ao espaço privado o resultado não foi diferente. Com a súbita explosão demográfica de São Paulo, não tardou para que as moradias populares ocupassem o centro da Capital. Incomodado, Antonio Prado executou reformas que promoveram a verticalização das áreas centrais, bem como o retificamento e o alargamento de suas ruas. Foram demolidos, com isso, os remanescentes e numerosos casarões do período colonial e imperial, obrigando o afastamento dos moradores mais pobres para as residências preservadas nos arredores (Marins, 2006), para as proximidades das indústrias - onde se fixaram em terrenos baixos, baratos, alagadiços e insalubres, formando os denominados bairros operários como Brás, Bom Retiro, Luz, Mooca, Ipiranga e Pari (Glezer, 2007, p.172) - e para regiões periféricas da cidade. Nesses locais, uma multiplicidade social e étnica instalou-se nos mais diversos tipos de habitações, principalmente em cortiços, onde a alta densidade demográfica era a regra (Wissenbach, 2006, p.101). Amontoando-se em diminutos espaços que, não raro, serviam simultaneamente para cozinhar e dormir, e improvisando pequenas salas de estar nas calçadas repletas de cadeiras, estrangeiros, bem como ex-escravos e seus descendentes subvertiam a seu modo a idéia de privacidade das elites (Wissenbach, 2006; Marins, 2006). Se no interior dos palacetes urbanos a especialização de cada um dos inúmeros cômodos e a existência de jardins recuados, fechados por gradis altos, garantiam a intimidade das famílias (Marins, 2006), as duras condições de vida dos desvalidos levava-os a conceber o lar como uma experiência necessariamente compartilhada. Enquanto meios para a própria sobrevivência de seus ocupantes, as moradias populares eram palco de um cotidiano ambivalente, no qual emergiam desavenças, mas também uma “considerável solidariedade social” (Morse, 1970, p.298).

A superlotação, o acúmulo de pessoas e de animais domésticos nos mesmos ambientes, o uso coletivo de tanques para a lavagem de roupas, a precariedade material e a falta de saneamento básico rapidamente tornaram as habitações coletivas focos de epidemias de febre amarela, varíola, peste bubônica, febre tifóide, gripe espanhola, malária e tuberculose (Rago, 1997; Wissenbach, 2006; Marins, 2006). Para os higienistas sociais, tal fato evidenciava a incapacidade da população pobre em gerir sua própria vida, colocando em risco a saúde pública - o que significava a ameaça de alastramento das moléstias para os bairros ricos da cidade. Por isso, atribuíam-se o direito de intervir nas formas populares de moradia, 
pondo fim à aglomeração do espaço doméstico, o que permitiria a entrada de luz natural e o fluxo de ar e de água ${ }^{49}$.

Além de ser a origem dos surtos epidêmicos, o modo de vida do pobre na esfera privada, ao ver do poder público, acarretava sérios problemas de natureza moral, tais como o abandono do lar pelo chefe de família, a promiscuidade, a perversão, o jogo, o roubo e o alcoolismo (Paoli \& Duarte, 2004, p.70). Mais do que recuperar a saúde física dos moradores, portanto, o objetivo da política sanitarista era reformar moralmente aqueles tidos como feios, toscos, incivilizados, sujos, animalescos, ignorantes, supersticiosos e desordeiros (Rago, 1997; Paoli \& Duarte, 2004, p.73). Para isso, uma das medidas sugeridas pelos responsáveis pela higiene pública foi a construção, nos bairros periféricos, das chamadas vilas operárias. Uma das mais conhecidas foi a Vila Maria Zélia, no Belenzinho, erguida nas primeiras décadas do século XX por Jorge Street, proprietário da "Companhia Nacional de Tecidos de Juta". As vilas permitiam aos industriais exercer a vigilância e o controle absolutos sobre todos os momentos da vida do operário, uma vez que não havia necessidade de delas sair nem mesmo para trabalhar: as casas eram dispostas ao redor das fábricas ou essas circundavam as primeiras. Além disso, creches, escolas, farmácias, campos de futebol, igreja, parque, armazém, entre outros equipamentos coletivos, preenchiam as necessidades básicas dele e de suas famílias. Confinado nos limites dessas cidades em miniatura, ao trabalhador restava desfrutar seu tempo livre nos poucos espaços de sociabilidade disponíveis e obedecer a uma rígida disciplina da qual fazia parte, por exemplo, o toque de recolher e a proibição de ingerir bebidas alcoólicas. Quanto às moradias, apesar de baratas - o aluguel era descontado no salário do operário -, elas deviam ser não apenas higiênicas, mas também confortáveis e aconchegantes, propiciando o apego ao lar e o estreitamento dos laços familiares, vistos como fundamentais para a restauração moral. De fato, no entender do poder patronal, tanto o refúgio dos trabalhadores nos bares quanto a preferência das crianças pelas ruas, onde poderiam se tornar futuros delinqüentes, eram resultado de um ambiente doméstico no qual predominava uma atmosfera deletéria para o corpo e para o espírito. Nesse caso, era imprescindível a formação de uma família nuclear, solidamente constituída através de um casamento monogâmico e onde os papéis sociais seriam redefinidos. $\mathrm{O}$ homem devia ser dócil, submisso

\footnotetext{
${ }^{49}$ A partir do século XVIII, foi forte a influência no discurso médico da teoria dos fluidos, que preconizava que o ar e a água eram veículos transmissores de miasmas que, se inalados, poderiam desequilibrar o organismo ao impedir a circulação sanguínea e, logo, provocar doenças. Embora Louis Pasteur tenha discordado dessa versão ao formular, nos anos de 1870 , a teoria dos micróbios, segundo a qual o contágio ocorre por outros meios, como o contato com pessoas infectadas, a busca pela assepsia das habitações coletivas continuou a ser orientada pelo desejo de torná-las salubres, ou seja, bem iluminadas e onde o ar e a água circulassem livremente (Rago, 1997).
} 
e laborioso, o que seria possível através da criação de um elo emocional entre o operário e o empregador. Por outro lado, se a esfera pública do trabalho era de domínio masculino, na esfera privada do lar a mulher devia reinar soberana: como dona-de-casa, esposa e mãe, a ela cabia zelar pela higiene da habitação, pela saúde do marido e dos filhos, bem como afastar ambos dos comportamentos desviantes. A criança, por sua vez, devia ser alvo de cuidados especiais, que evitassem as altas taxas de mortalidade, o que exigia substituir os hábitos arraigados das camadas populares pela observância dos saberes científicos da puericultura (Rago, 1997).

A opção de residir em vilas operárias, entretanto, estava ao alcance de um pequeno número de trabalhadores: além de determinadas fábricas, como a "Antarctica", entregar as moradias somente para os funcionários mais especializados (Rago, 1997, p.188), era preciso um alto investimento de capital, que apenas alguns grandes empresários podiam disponibilizar (Segawa, 2004, p.352). Por isso, grande parte da mão-de-obra industrial, assim como o restante dessa população de baixa renda, foi obrigada a enfrentar condições subumanas de habitação. Como bem resume Hobsbawm (1982, p.224), o "desenvolvimento urbano foi um gigantesco processo de segregação de classes, que empurrava os novos trabalhadores pobres para as grandes concentrações de miséria alijadas dos centros de governo e dos negócios, e das novas áreas residenciais da burguesia". Foi na gestão do prefeito Raymundo Duprat (1911-1914) que teve início a formação dos denominados bairros-jardim, onde as elites ávidas por manter-se longe das mazelas sociais da cidade, que cresciam na mesma proporção em que essa se expandia - podiam residir tranqüilamente. O primeiro loteamento desse novo tipo de empreendimento imobiliário, iniciativa da "Companhia City", foi o Jardim América, que começou a tomar forma em 1913 (Marins, 2006).

A despeito da crescente intenção lucrativa do capital imobiliário e da ausência de uma política habitacional, devem ser ressaltadas algumas das tentativas do poder público de eliminar a abissal distância entre as precárias construções superpovoadas e as opulentas e salubres residências dos afortunados: em 1886, o Código de Postura do Município incluía um capítulo sobre "Cortiços, Casas de Operários e Cubículos", que definia normas profiláticas para a construção das moradias populares; após uma epidemia de febre amarela em 1893, foi promulgado um ano depois o Código Sanitário do Estado de São Paulo que, através do capítulo intitulado "Habitações das Classes Pobres", estabelecia a proibição de cortiços e a eliminação dos já existentes (Rago, 1997, p.170-171; Patto, 1999, p.178). Além da legislação urbana, outro procedimento adotado foi a vistoria minuciosa dos domicílios para a aplicação 
de medidas que iam desde a simples higienização ou interdição até à derrubada dos mesmos ${ }^{50}$. A cada interferência, no entanto, as autoridades sanitárias esbarravam não apenas em resistências e manifestações por parte dos grupos populares ${ }^{51}$, como ainda na intensa mobilidade desses, o que provocava a reposição da miséria em outros lugares (Wissenbach, 2006, p.107).

Mas não foi somente no tocante à questão da moradia que as dificuldades da vida urbana afligiam a população pobre. Submetidos a uma extensa jornada de trabalho, a baixos salários e a um arbitrário regulamento que abrangia, entre outras estratégias disciplinares, o rígido controle do tempo por parte de superiores hierárquicos para evitar a perda de produtividade e a proibição de tudo aquilo que pudesse impulsionar a tomada de consciência de classe - que então se constituía -, como conversas, leituras, troca de informações, os trabalhadores fabris procuraram lutar por direitos ainda não assegurados pela legislação. A destruição de máquinas e de instrumentos de trabalho, a sabotagem, o roubo, o boicote e a inutilização da matéria-prima consistiam em algumas das formas desenvolvidas pela inventividade operária para contestar o tratamento patronal recebido que, muitas vezes, apelava à violência física e moral (Rago, 1997). Foram as greves, contudo, que, ao ultrapassarem os muros das fábricas, tornaram públicos os conflitos nas relações entre o trabalho e o capital do nascente sistema industrial (Paoli \& Duarte, 2004). No início dos anos de 1890, o anarquismo - braço do movimento operário cujo auge ocorreu na Europa e nos Estados Unidos entre as últimas décadas do século XIX e o começo da Primeira Guerra Mundial - tornou-se a principal influência dos trabalhadores (Hall, 2004b; Fausto, 2007) ${ }^{52}$. Muitos fatores, porém, impediram o sucesso das reivindicações operárias. Um deles era a ampla oferta de mão-de-obra, o que permitia aos industriais manterem seu espaço produtivo sempre ocupado, mesmo oferecendo uma parca remuneração. O fato dos proletários serem em sua maioria estrangeiros também representou obstáculos para sua organização em sindicatos, dado que, além de temerem a deportação, eles envolviam-se em intensas rivalidades étnicas (Hall, 2004b).

\footnotetext{
${ }^{50}$ Americano (2004, p.414, grifos meus) relata que as ações sanitárias atingiam também as populações mais favorecidas, "gente que se indignava da constância e da meticulosidade dessas visitas domiciliares: 'Minha casa não é cortiço"”.

${ }^{51}$ A Revolta da Vacina, ocorrida em 1904 na cidade do Rio de Janeiro, foi um dos mais significativos episódios de resistência popular do período. Ver Sevcenko (1984).

${ }^{52}$ A ação dos anarquistas foi pautada pelo intuito de modificar radicalmente a sociedade, ou seja, de implantar uma sociedade livre e justa, na qual inexistiria o Estado e fosse possível a auto-gestão da produção e a concretização de uma nova proposta educacional, entre outras aspirações (Rago, 1997).
} 
Apesar disso, em meados de 1917 eclodiu a primeira e a maior greve geral na história da cidade, reflexo do descontentamento operário com o aumento no preço dos gêneros alimentícios, fruto da Primeira Guerra Mundial, e da Revolução de fevereiro de 1917, que derrubou o poder czarista na Rússia. Iniciada no Cotonifício Crespi, na Mooca, a maior da categoria na Capital, o movimento logo alastrou-se para as demais fábricas têxteis e para empresas de móveis e de cervejas. No decorrer de três dias, as ruas foram tomadas por 50 mil pessoas, entre eles mulheres e crianças, empregados fartamente pela indústria têxtil e que, não raro, eram aproveitados no trabalho noturno (Hall, 2004b; Fausto, 2007). Saques a armazéns, barricadas, comícios, piquetes e ataques a bondes promovidos pelos grevistas foram, não obstante, severamente contidos pela polícia. Preocupado com a grande repercussão do movimento, o Estado ignorou os acordos que puseram fim a este: reforçou o aparato repressivo por meio de detenções, de espancamentos, do fechamento de sindicatos, da proibição de passeatas, do emprego de espiões e, especialmente, da expulsão do país dos líderes (Hall, 2004b).

\subsection{A criação e a expansão dos diferentes tipos de escolas primárias no contexto do processo de modernização educacional}

Como foi possível observar, a expansão cafeeira, "incessante e vigorosa até 1929" (Antunha, 1976, p.26), foi o ponto de partida do desenvolvimento econômico do Estado de São Paulo. Com os lucros gerados pelo café, pôde ser iniciada a modernização de cidades como Ribeirão Preto, Campinas ${ }^{53}$ e a própria capital. A introdução de benefícios oriundos da Revolução Científico-Tecnológica, como a energia elétrica e o telefone; o alargamento de ruas e de avenidas; a instalação de fábricas, de bancos e de casas comerciais e as mudanças na arquitetura das construções foram alguns dos melhoramentos urbanos realizados a partir de 1870 e mais facilmente visíveis na história da cidade de São Paulo. O desfrute desse progresso, contudo, esteve ao alcance de uma parcela mínima e, portanto, privilegiada da

\footnotetext{
${ }^{53}$ Em viagem pela Província de São Paulo entre 1860 e 1861, Zaluar assim registrou suas impressões da cidade de Campinas (p.134-136): “O progresso geral acelera-se aqui com rapidez notável (...). A cultura do café, que é hoje a principal do município, data apenas de trinta anos, que foi introduzida, e vinte, que tem tomado o seu incremento. (...) Há na cidade sessenta e quatro lojas de fazendas e ferragens, vinte armazéns de gêneros de fora, e cento e dez tavernas, o que tudo paga direitos à municipalidade. Além destas, há três fábricas de licores, duas de cerveja, uma de velas de cera, uma de chapéus, três hotéis, duas casas de bilhares, diversas lojas de alfaiates, sapateiros, latoeiros, caldeireiros, torneiros, marceneiros, seleiros, armadores, quatro padarias, uma fábrica de charutos, três relojoeiros, três ourives, três retratistas em daguerreotipo e um a óleo, três pintores hábeis, e uma tipografia (...). Além das casas de comércio já declaradas, existem três de comissões de importação em ponto grande. O comércio é pois ativo e florescente (...)”.
} 
população paulista. Ávidas por igualar as cidades às principais capitais européias, as elites não se importaram em restringir a participação de imigrantes, nacionais pobres e negros libertos nesse processo ao seu elemento principal: a força de trabalho. Mais do que isso, seguras em seus casarões, elas não souberam resolver o problema da falta de moradias, que se agravava na mesma proporção em que crescia a população. E quanto à educação primária? O que fizeram os responsáveis pela gestão pública para satisfazer seu desejo irrefreável de renovar a fisionomia das cidades e ainda contemplar a constante demanda por vagas, fruto dessa explosão demográfica? Compreender o processo de criação das escolas-modelo, dos grupos escolares, das escolas isoladas, das escolas-modelo isoladas e das escolas reunidas, bem como sua respectiva expansão geográfica, é fundamental no caso da presente dissertação. Isso porque a opção do Estado em diferenciar os programas de ensino é indissociável do peso conferido por ele a cada um desses tipos de escolas primárias.

\subsubsection{As escolas-modelo: onde começa a modernização}

A escola era bem organizada. Cesário Motta, Caetano de Campos, Miss Brown, norte-americana que vivera alguns anos no Rio de Janeiro, tinham modernizado o ensino. Os professores amavam a tarefa. Ensinava-se bem.

Jorge Americano

No entender de políticos, intelectuais e educadores do início da República, o sistema público primário paulista herdado do regime político anterior era incipiente, pouco contribuindo com a quantidade e a qualidade da educação popular e devendo, pois, ser disseminado e reorganizado, ou melhor, modernizado. A tarefa, porém, não era simples, dado que eram ambiciosas as aspirações dos republicanos. Com efeito, se a educação já era considerada, desde os anos finais do Império, como meio para o progresso e para a civilização, para a regeneração da sociedade e para a libertação do povo da ignorância, a ela cabia agora mais um papel, fortemente influenciado pela vitória das idéias liberais na organização da República: a formação do cidadão republicano, ou seja, capacitá-lo para o auto-governo. Isso porque o liberalismo, importado dos Estados Unidos e cuja difusão originou-se ainda no período imperial, consistiu na defesa da democracia representativa, na qual os eleitos representariam o conjunto dos cidadãos, governando em seu nome (Reis Filho, 1995). Se o que se construía era um Estado dito democrático, tornava-se imprescindível 
fornecer a educação para o povo, como demonstra o relatório apresentado por Caetano de Campos, então Diretor da Escola Normal, ao governador do Estado, Prudente de Moraes, em 1891: "Para o Governo educar o povo é um dever e um interesse: dever, porque a gerencia dos dinheiros publicos acarreta a obrigação de formar escolas; interesse, porque só é independente quem tem o espirito culto, e a educação cria, avigora e mantêm a posse da liberdade" (In: Educação, julho de 1929, n. 01, ano VIII, p.11).

Orientado pelos princípios da gratuidade, da universalidade, da obrigatoriedade e da laicidade do ensino ${ }^{54}$ e inspirado no modelo de educação norte-americana (Reis Filho, 1995), Caetano de Campos foi colaborador ${ }^{55}$ do primeiro investimento público na educação popular após o advento da República. A chamada "Reforma Caetano de Campos" (Decreto n. 27, de 12 de março de 1890) reformulou a Escola Normal e transformou as escolas anexas a ela em escolas-modelo. O que fundamentava a medida foi a crença de Caetano de Campos de que simplesmente criar e manter escolas, sem uma adequada formação docente, seria como entregar "um navio a um marinheiro que nunca navegou - é insensato" (In: Educação, julho de 1929, n. 01, ano VIII, p.19). Em outros termos, desde cedo "os republicanos-democratas paulistas dos primeiros meses da República identificam com rigor o passo essencial para a renovação eficiente do ensino: a preparação científica e técnica do professor” (Reis Filho, 1995, p.51). Para tanto, além da reforma no programa de ensino da Escola Normal ${ }^{56}$, foi instituída a escola-modelo, como especifica o Artigo 20 do Decreto n. 27: “Annexas à Escola Normal, funccionarão duas escolas-modelo, uma para cada sexo, para nellas praticarem a regencia das cadeiras os alumnos do $3^{\circ}$. anno daquella Escola”. A brasileira Maria Guilhermina Loureiro de Andrade e a norte-americana Miss Márcia Priscila Browne foram as duas professoras contratadas para assumirem, respectivamente, a direção da seção feminina e a masculina da "1". Escola-Modelo", anexa à Escola Normal da Praça da República e mais conhecida como Escola-Modelo "Caetano de Campos". Enquanto a primeira estudou durante quatro anos nos Estados Unidos, a segunda era ex-diretora de uma Escola Normal no mesmo país, mas ambas foram indicadas por Horácio Lane, diretor da Escola Americana. As duas seriam responsáveis, além disso, pela introdução, no então nascente sistema público de ensino paulista, daquele considerado o método de ensino por excelência: o intuitivo ${ }^{57}$ (Reis Filho,

\footnotetext{
${ }^{54}$ A obrigatoriedade e a gratuidade escolar primária foram estabelecidas pela Constituição Estadual de 14 de julho de 1891 (Antunha, 1976, p.47).

${ }_{55}$ Conforme Tanuri (1979, p.84), "não foi Caetano de Campos, mas Rangel Pestana o mentor intelectual da primeira reforma republicana do ensino normal. Caetano de Campos foi apenas o executor da reforma".

${ }^{56}$ Ver Tanuri (1979) e Reis Filho (1995).

${ }^{57} \mathrm{O}$ método intuitivo foi adotado pela primeira vez pelo Ministro Leôncio de Carvalho, no âmbito da reforma do ensino primário e secundário no município da Corte, em 1879 (Souza, 1997, p.145). Foi, contudo, em 1882 que
} 
1995).

Era na escola-modelo que os futuros professores teriam a possibilidade de observar o funcionamento do método intuitivo, visto por Caetano de Campos como o alicerce do ensino moderno (Carvalho, 1989). Para o educador, "é indispensavel que o alumno traga da escola primaria a disciplina mental da intuição" (In: Educação, julho de 1929, n. 01, ano VIII, p.17). Por iniciativa de discípulos de Pestalozzi, o método intuitivo começou a ser disseminado na Alemanha, em 1825, bem como no restante da Europa e nos Estados Unidos, no decorrer do século XIX (Reis Filho, 1995). Se no método empregado nas escolas régias ${ }^{58}$ as "crianças decoravam tudo, para em breve tudo esquecer" (Campos, 1891; In: Educação, julho de 1929, n. 01, ano VIII, p.12), o novo método buscava adequar o ensino às fases do desenvolvimento infantil, ao preconizar que era através dos sentidos que se iniciava a vida mental, ou seja, a aquisição do conhecimento. O professor deveria, pois, decompô-lo em elementos os mais simples possíveis e, progressivamente, aumentar sua complexidade, já que "cada idade deve aprender determinada ordem de noções" (Campos, 1891; In: Educação, julho de 1929, n. 01, ano VIII, p.13). Se a "intuição foi o processo que instruiu a humanidade inteira em sua vida intellectual” (Campos, 1891; In: Educação, julho de 1929, n. 01, ano VIII, p.20), acreditavase que nada mais natural do que permitir que o indivíduo reproduzisse, ao longo de sua aprendizagem, o mesmo percurso (Carvalho, 1989). Caetano de Campos deixava claro, no entanto, que o método intuitivo era compatível apenas com um ensino que fosse "quanto possivel, (...) completo, inteiro em todos os ramos de conhecimentos indispensaveis á vida, encyclopedico por assim dizer, já que nosso viver social na actualidade envolve-nos em contingencias oriundas de toda sorte de noções scientificas" (In: Educação, julho de 1929, n. 01, ano VIII, p.14). Proporcionar um ensino baseado em conhecimentos científicos - condição necessária para a cidadania plena (Carvalho, 1989) - exigia que a educação para o povo abrangesse o nível primário e o secundário, esse oferecido em escolas de $2^{\circ}$. e de $3^{\circ}$. graus. Por isso, a escola-modelo foi estruturada em três graus, sendo "admittidos á matricula alumnos de 7 a 10 annos de edade para o primeiro gráu; de 10 a 14 para o segundo, e de 14 a 17 para o terceiro" (Artigo 116 do Regulamento da Escola Normal de São Paulo, de 14 de junho de 1890). Apesar disso, apenas o $1^{\circ}$. grau foi implantado, sendo que o número de anos de duração do curso variou ao longo do período estudado, como será assinalado posteriormente.

os princípios e fundamentos do método foram apresentados pela primeira vez no país, através dos Pareceres de Rui Barbosa (Souza, 2000b, p.10).

${ }^{58}$ Ver Souza, M. (1998). 
O sucesso da adoção do método intuitivo no ensino primário - a escola-modelo deveria consistir também na referência para a organização das demais escolas primárias dependia ainda do provimento de materiais didáticos, utilizados no ensino de quase todas as matérias. Deve-se isso ao fato de que o novo método supunha que a "mais vantajosa disciplina da intelligencia é a observação correcta. (...) Procurar a verdade no mundo concreto que nos rodeia é, segundo o criterio actual, o mais util processo para aprender" (Caetano de Campos, 1891, p.22). Nesse sentido, para a prática das "lições de coisas", como ficou comumente conhecido o método intuitivo, era essencial permitir o acesso da criança aos mais variados objetos. Aluno do $1^{\circ}$. ano da Escola-Modelo "Caetano de Campos" em 1898, Jorge Americano (2004, p.30) recorda alguns deles:

Pauzinhos do tamanho de meios-palitos, para aprendizado de somas e subtrações. Cartões em cores variadas, de formas triangulares, poligonais, para geometria. Pequenos cubos, cones, pirâmides, cilindros de madeira, para geometria no espaço. Cartões de cortes longitudinais paralelos e fitas estreitas de papel de cor, lustroso, para tecer sobre os cartões, como nos tapetes dos índios americanos e nos ornatos mouros e egípcios. (...) Havia também aula de ginástica sueca no pátio de recreio, com bastões, marchas, corridas, saltos de trampolim, subida de corda, pulos de cavaletes, exercício de paralelas e barra fixa.

Como centro irradiador da primeira grande inovação no ensino público primário - o método intuitivo - a escola-modelo pretendia afastar para sempre o "passado de trevas, obscurantismo e opressão (Carvalho, 1989, p.23) associado à educação da fase imperial. Dessa forma, elementos que evidenciassem a adequação desse tipo de escola ao que havia de mais moderno no ensino receberam atenção especial por parte dos reformadores. Um deles foi a substituição dos antigos e longos bancos, nos quais se sentavam as crianças, por carteiras (Reis Filho, 1995). Além do novo mobiliário escolar, as lições passaram a ser curtas, entremeadas de exercícios de marcha, canto e ginástica, como continua a descrever Americano (2004, p.30):

\footnotetext{
Quando dava o cansaço, dez minutos de cântico em aula. Novos estudos. Novo cansaço, os meninos faziam marcha ritmada em torno da sala, ao som de palmas da professora, ou com música de piano. No próximo descanso, ginástica ritmada, dos braços, na sala.
}

Outra novidade foi a construção de edifícios planejados especialmente para abrigar a escola-modelo. Se no Império as escolas de primeiras letras funcionavam nas residências dos professores, provocando sérios inconvenientes, a pedagogia moderna defendia a idéia de que as atividades escolares não poderiam ser realizadas a não ser em espaços convenientemente preparados para tais. Por isso, foram chamados conceituados arquitetos como Ramos de 
Azevedo que, conforme afirmado antes, projetou outros prédios públicos como o Teatro Municipal. Assim como esse, a arquitetura escolar foi marcada pela suntuosidade, de modo a deixar incontestável a valorização da escola pelos republicanos. Além de propaganda da ação governamental no tocante à educação, o cuidado com o aspecto estético da escola tinha a função de elevar o prestígio dela e, por conseqüência, do professor, perante toda a sociedade (Antunha, 1976; Escolano, 2001). Os professores da escola-modelo eram normalistas, selecionados entre os melhores, e exerceram, mais tarde, funções importantes na área da educação, como a direção de grupos escolares e a publicação de livros didáticos, manuais pedagógicos e artigos na imprensa periódica (Souza, 1997).

A concepção do edifício-escola foi pautada ainda pelo princípio de que a arquitetura escolar é um "programa invisível e silencioso" (Escolano, 2001, p.47), ou seja, é por meio dela que a criança internaliza determinados valores, hábitos e comportamentos, tais como a ordem, a higiene, a vigilância, a disciplina e a pontualidade. Em suma, considerava-se que, assim como todo espaço, o escolar também era educativo (Viñao Frago, 2001). Tratava-se, desse modo, tanto de prover a escola renovada de espaços especializados, amplos, arejados e iluminados - de acordo com os preceitos higiênicos em voga -, quanto de certos símbolos, como a bandeira nacional e o relógio (Escolano, 2001). A despeito disso, apenas duas escolasmodelo atendiam os alunos em prédios próprios: a "1". Escola-Modelo", denominada de Escola Preliminar "Caetano de Campos" a partir do Decreto n. 397, de 09 de outubro de 1896, além da Escola-Modelo "Prudente de Moraes, no bairro da Luz, criada pelo Decreto n. 280, de 01 de fevereiro de 1895 e conhecida como “ 3 a . Escola-Modelo". Ambas foram projetadas por Ramos de Azevedo. Por outro lado, a Escola-Modelo "Maria José", instaurada através do Decreto n. 321, de 03 de dezembro de 1895, funcionava num prédio cedido por Fernando de Albuquerque, mas que estava em precárias condições. Por sua vez, era modesto o edifício onde foi instalada, a partir do Decreto n. 252, de 09 de agosto de 1894, a Escola-Modelo do Carmo, conhecida como " 2 a . Escola-Modelo" desde a transferência da "1a . Escola-Modelo" da rua da Boa Morte para a Praça da República, em 02 de agosto de 1894. Enquanto a Capital foi provida dessas quatro escolas-modelo, no interior foi fundada apenas uma, em 1895: a de Itapetininga, que deveria ser anexa à Escola Normal da cidade. No entanto, no lugar dessa foi criada uma Escola-Modelo complementar (Decreto n. 428, de 06 de fevereiro de 1897), passando a Escola-Modelo de Itapetininga a ser destinada à prática de ensino dos alunos complementaristas (Reis Filho, 1995; Souza, 1997; Marcílio, 2005).

Progressivamente, à exceção da Escola-Modelo "Caetano de Campos", todas as 
demais passaram a funcionar como grupos escolares. A Escola-Modelo do Carmo, por exemplo, foi oficialmente transformada em Grupo Escolar do Carmo em 01 de outubro de 1894. A equiparação das escolas-modelo aos grupos escolares foi determinada pela Lei n. 930, de 13 de agosto de 1904 (Souza, 1997).

\subsubsection{Os grupos escolares: vitrines do progresso}

A experiencia me tem demonstrado á saciedade, em 18 annos de tirocinio, que o typo de organização escolar mais perfeito, que melhores resultados apresenta, é incontestavelmente, o de agrupamento das escolas. Sob todos os aspectos o grupo escolar se impõe; elle concretiza o feliz ideal, a concepção mais completa de um instituto modelar de ensino e educação.

José Monteiro Boanova (inspetor escolar, nos Anuários do Ensino do Estado de São Paulo de 1910-1911)

A experiência adquirida com a inauguração da primeira escola-modelo, em 1890, propiciou o surgimento de uma nova modalidade de escola pública primária: os grupos escolares (Reis Filho, 1995, p.207). Não por acaso, neles devia ser estabelecido o regime e o método de ensino das escolas-modelo do Estado (Artigo 57 do Decreto n. 518, de 11 de janeiro de 1898). Entretanto, a primeira Reforma Geral da Instrução Pública (Lei n. 88, de 08 de setembro de 1892) não previa a instituição dos grupos escolares. A partir dela, o ensino primário - obrigatório para crianças de idade entre sete e doze anos, de ambos os sexos - fícou dividido em dois cursos de 4 anos cada um: o preliminar e o complementar, reservado aos alunos habilitados nas matérias do primeiro. O Decreto n. 144-B, de 30 de dezembro de 1892, que aprovou o Regulamento da Instrução Pública, adicionou algumas disposições à Lei n. 88. O ensino primário continuou a compreender o curso preliminar - que seria ministrado nas escolas preliminares e nas suas auxiliares, a saber, as escolas intermédias e as escolas provisórias - e o complementar:

Art.50 - Das escolas públicas já creadas no Estado são consideradas preliminares as que atualmente se acham sob a regência de professores normalistas; intermédias, as regidas por professores habilitados de acôrdo com os regulamentos de 18 de abril de 1869 e 22 de agôsto de 1887; provisórias, as que forem preenchidas por professores interinos, examinados perante os inspetores de distrito.

Assim sendo, como esclarece Antunha (1976, p.64), a primeira classificação das escolas primárias no período republicano, foi baseada no 
critério de regência, o que indica, de um lado, a existência de um certo número de professores sem título, como seria de esperar-se, advindos dos tempos do Império, e de outro, a quantidade insuficiente de professores formados pela Escola Normal para preencher os postos existentes, como o indica a própria instituição da figura do professor provisório.

No caso das escolas preliminares, onde deveria haver completa separação dos sexos, os professores só podiam ministrar em escolas do sexo masculino e as professoras foram incumbidas das escolas do sexo feminino e das mistas, abertas apenas em casos excepcionais (Reis Filho, 1995, p.136).

O Decreto n. 144-B ainda definia, por meio do Artigo 51, que a

creação de novas escolas de curso preliminar fica dependente do número de alunos matriculáveis, nas seguintes bases:

$1^{\text {a }}$. - Em toda a localidade do Estado onde houver de 20 a 40 alunos matriculáveis haverá uma escola preliminar (art. $2^{\circ}$. da Lei n. 88)

$2^{\text {a }}$. - Si o número de alunos for inferior a 80, haverá duas escolas, e si for superior serão creadas tantas escolas, quantas sejam necessárias, na proporção de 40 alunos para cada escola (art. $2^{\circ}$., parágrafo único da Lei n. 88 )

$3^{\mathrm{a}}$. - Nos lugares em que o número de alunos ou alunas matriculáveis for inferior a 20, mas puder formar-se esse número com alunos de ambos os sexos, será creada uma escola mista (art. $3^{\circ}$. da Lei n. 88)

$4^{\mathrm{a}}$. - Nos lugares em que as circunstâncias o exigirem, a juízo do Conselho Superior, será creada uma escola ambulante ${ }^{59}$ (art. $3^{\circ}$., parágrafo único da Lei n. 88).

A partir de 1895, quando ao curso complementar foi facultado a possibilidade de formar professores preliminares, o ensino primário ficou reduzido ao curso preliminar de 4 anos, duração essa que, conforme será mostrado posteriormente, não se manteve para todos os tipos de escolas primárias. Até 1911, quando foram transformados em escolas normais primárias, os cursos complementares foram, praticamente, o principal meio de formação de docentes para as escolas primárias. Isso porque, além de ser exíguo o número de egressos da Escola Normal, alguns deles ocupavam postos na administração do ensino ou mesmo no magistério, mas em outros níveis (Tanuri, 1979, p.103).

Foi somente através da Lei n. 169, de 07 de agosto de 1893, que os grupos escolares foram criados: "Art. $1 \S 1^{\circ}$. - Nos logares em que, em virtude da densidade da população houver mais de uma escola no raio fixado para a obrigatoriedade, o Conselho Superior poderá

\footnotetext{
${ }^{59}$ Nas escolas ambulantes, o professor deveria "demorar-se em cada um dos pontos dos bairros sujeitos ao seu percurso o tempo preciso para que, reunidos os meninos da vizinhança, lhes dê o ensino do curso preliminar, de modo que nenhum aluno deixe de receber lições com intervalo maior de oito dias" (Artigo 60). Sobre essas escolas, o pouco que se conhece é que, legalmente, várias delas foram criadas (Antunha, 1976, p.65).
} 
fazel-as funccionar em um só prédio, que para esse fim será construido no ponto mais conveniente". A denominação "grupos escolares", todavia, apareceu somente no Decreto n. 248, de 26 de julho de 1894, que aprovou o Regimento Interno das escolas públicas do Estado de São Paulo. O documento ainda previa que:

Art. 82 - Cada grupo escolar poderá comportar a lotação de 4 a 10 escolas isoladas no maximo e será regido por tantos professores quantos forem os grupos de 40 alumnos e pelos adjunctos que forem necessarios á directoria.

$\S 1^{\circ}$. - Pódem funccionar no mesmo edificio escolas do sexo masculino e do feminino, havendo completa separação dos sexos.

Concebidos segundo o modelo de escola graduada - difundido em países como a Inglaterra, a França, a Espanha e os Estados Unidos a partir do final do século XIX - os grupos escolares representaram um dos principais símbolos da modernização educacional promovida no Estado de São Paulo. Neles, os alunos de nível de adiantamento semelhante eram distribuídos na mesma classe, regida por um só professor e que correspondia, cada uma, a uma sala de aula e a uma série. Num grupo escolar havia duas classes para cada ano letivo (uma para meninas e outra para meninos). Com essa organização didático-pedagógica baseada na racionalidade científica e na divisão do trabalho docente, a escola graduada engendrou modificações significativas no ensino primário, algumas delas mantidas ainda hoje. Se nas antigas escolas de primeiras letras, onde se adotava o método individual de ensino, o tempo de contato direto do professor com o aluno era reduzido, nos grupos escolares o professor podia ensinar a todos simultaneamente. Com a ampliação do tempo escolar, era imprescindível a elaboração de programas de ensino mais extensos, bem como a estruturação de quadros que especificassem a rotina escolar, isto é, os horários em que seriam ministradas as matérias e a duração de cada uma dessas atividades (Souza, 1997; Faria Filho, 2002; Gallego, 2003). Ademais, assim como nas escolas-modelo, nos grupos escolares o ensino das matérias devia ser baseado no método intuitivo. Por fim, essa nova relação entre método, tempo e saberes escolares tornou necessária a aplicação de exames no decorrer do ano, de forma a determinar a aprovação ou não do aluno para a série subseqüente. Pelo Regimento Interno das escolas públicas do Estado de São Paulo (Decreto n. 248, de 26 de julho de 1894), os exames seriam públicos e classificados em três modalidades: escritos (ditado, composição e questões práticas de aritmética), práticos (caligrafia e desenho) e orais (todas as demais matérias) ${ }^{60}$.

\footnotetext{
${ }^{60}$ Da realização dos exames - os quais eram acompanhados pelos pais e pela população - estavam encarregadas bancas das quais faziam parte o inspetor de distrito (presidente), dois examinadores por ele nomeados e o próprio professor da escola ou classe (Artigo 46 do Decreto n. 248). Como meio de emulação e disciplina, eram
} 
Para o sucesso dessa nova cultura escolar, considerava-se essencial a presença de um profissional que até então só existia nas escolas-modelo: o diretor. Visto como o interlocutor dos professores com o poder público, ele era livremente nomeado pelo governador do Estado entre os docentes formados pela Escola Normal ou, na falta desses, pela escola complementar, contanto que os mesmos tivessem passado pela experiência da prática de ensino. Outra possibilidade era a indicação de um inspetor de distrito. O diretor podia ser identificado, portanto, como uma autoridade do governo, o que lhe garantia legitimidade para assumir o cargo. Entre suas atribuições, que no transcorrer do período sofreram acréscimos e possuíam caráter administrativo e pedagógico (Souza, 1997), estavam:

Art. $84 \S 1^{\circ}$. - Representar a escola em todas as suas relações externas; $\S 2^{\circ}$. Fiscalizar todas as classes durante o seu funccionamento, imprimindo-lhes a direcção que julgar conveniente ao ensino; $\S 3^{\circ}$. - Imprimir nos 'Grupos Escolares' o typo de organização e methodo de ensino das escolas-modelo do Estado (Decreto n. 248, de 26 de julho de 1894).

O trabalho docente devia, pois, ser continuamente supervisionado pelo diretor. Apesar disso, a oportunidade de exercer o magistério nos grupos escolares era almejada por muitos professores, uma vez que, se comparadas às das escolas isoladas, a remuneração e as condições de trabalho das escolas graduadas eram melhores. Aliado a isso, estava o fato de que, ao encarnarem o tipo ideal de escola primária, como afirmou o inspetor escolar José Monteiro Boanova na epígrafe, os grupos escolares conferiam prestígio àqueles que neles trabalhavam, especialmente às mulheres, levando em conta que a posição de diretor de grupo escolar era ocupada quase exclusivamente por homens (Souza, 1997). Dados apresentados nos

Anuários do Ensino do Estado de São Paulo de 1911-1912 permitem inferir que a maioria do corpo docente dos grupos escolares, tanto da Capital quanto do interior do Estado, era feminina e diplomada, em grande parte, pela Escola Normal e pelos cursos complementares, respectivamente. A predileção dos professores pelas escolas graduadas também pode ser explicada pela localização desses estabelecimentos.

Os grupos escolares formavam uma modalidade de escola tipicamente urbana, destinada a oferecer a escolarização em massa a uma população que, como adiantado, crescia rapidamente (Souza, 1997). Eles foram instalados, pois, na Capital e nas cidades do interior, em prédios adaptados - próprios do Governo ou alugados - ou construídos especialmente para seu funcionamento. Nesse caso, são exemplos o $1^{\circ}$. Grupo Escolar do Brás (1898) e o Grupo

entregues prêmios aos alunos com os melhores resultados, oferecidos por comerciantes e autoridades políticas, que viam esses acontecimentos sociais como uma oportuna forma de publicidade (Souza, 1997, p.231). 
Escolar da Avenida Paulista (1919), ambos assinados por Ramos de Azevedo. Edificados segundo uma concepção arquitetônica que primava pela monumentalidade e pela disponibilidade de espaços com funções específicas (gabinete do diretor, biblioteca, sala dos professores, laboratórios, ginásio e pátio para recreio, entre outros), os grupos escolares destacavam-se na paisagem urbana e eram cobiçados pelas localidades que ainda não os possuía. Isso porque, embora fosse altamente dispendioso criá-los e mantê-los - sua organização didático-pedagógica e administrativa eram mais complexas - a presença deles era indicativo de progresso: "O grupo escolar (...) era um símbolo de modernização cultural, a morada de um dos mais caros valores urbanos - a cultura escrita" (Souza, 1997, p.83). Além disso, no interior, a instituição das escolas graduadas acelerava a urbanização e elevava o preço dos terrenos e dos imóveis no seu entorno (Costa, 1983, p.117-118).

A tabela abaixo, compilada a partir dos Anuários do Ensino publicados de 1907 a 1926, de Antunha (1976) e de Costa (1983) apresenta o número de grupos escolares existentes na Capital e no interior, no período $1898-1927^{61}$ :

TABELA 3

\begin{tabular}{|c|c|c|c|}
\hline Ano & Capital & Interior & Total \\
\hline 1898 & 8 & 30 & 38 \\
\hline 1899 & 8 & 27 & 35 \\
\hline 1900 & 10 & 35 & 45 \\
\hline 1901 & 10 & 39 & 49 \\
\hline 1902 & 10 & 41 & 51 \\
\hline 1903 & 11 & 47 & 58 \\
\hline 1904 & 11 & 51 & 62 \\
\hline 1905 & 13 & 55 & 68 \\
\hline 1906 & 15 & 57 & 72 \\
\hline 1907 & 16 & 60 & 76 \\
\hline 1908 & 18 & 63 & 81 \\
\hline 1909 & 24 & 68 & 92 \\
\hline 1910 & 25 & 77 & 102 \\
\hline 1911 & 25 & 85 & 110 \\
\hline 1912 & 26 & 89 & 115 \\
\hline 1913 & 27 & 103 & 130 \\
\hline 1914 & 28 & 122 & 150 \\
\hline 1915 & 28 & 132 & 160 \\
\hline 1916 & 29 & 135 & 164 \\
\hline 1917 & 30 & 140 & 170 \\
\hline 1918 & 30 & 146 & 176 \\
\hline 1919 & 31 & 154 & 185 \\
\hline 1920 & 31 & 164 & 195 \\
\hline 1921 & 31 & 166 & 197 \\
\hline & & & \\
\hline
\end{tabular}

${ }^{61}$ De acordo com os Anuários, em 1899, foram dissolvidos os grupos escolares de Bananal, São José dos Campos e Ubatuba e entre 1912 e 1916, o total de grupos escolares inclui o Jardim de Infância, a Escola-Modelo "Caetano de Campos" e as escolas-modelo de Itapetininga e de São Carlos, sobre a qual não foram encontradas informações. 


\begin{tabular}{|l|l|l|l|}
\hline 1922 & 31 & 167 & 198 \\
\hline 1923 & 31 & 168 & 199 \\
\hline 1924 & 31 & 169 & 200 \\
\hline 1925 & 41 & 228 & 275 \\
\hline 1926 & 47 & 236 & 283 \\
\hline 1927 & 47 & 242 & 289 \\
\hline
\end{tabular}

Como é possível concluir, na Capital, o processo de expansão dos grupos escolares foi intenso de 1898 a 1920, quando foi interrompido em virtude da Reforma Sampaio Dória ${ }^{62}$, que os transformou em suas "grandes vítimas" (Antunha, 1976, p.194). A partir de 1925, ano em que essa foi revogada, o ritmo foi retomado, sendo adicionados, aos 31 grupos escolares que já existiam, mais 16. Os primeiros grupos escolares inaugurados em dez anos (1894-1904) concentraram-se na região central e seus arredores: o GE do Carmo (10/08/1894), o GE Prudente de Moraes (25/03/1895), o GE do Sul da Sé (05/02/1896), o GE Maria José (11/04/1896), o GE da Santa Ifigênia (16/03/1896), o $2^{\circ}$. GE do Brás (04/11/1896), o $3^{\circ}$. GE do Brás (11/08/1898), o $1^{\circ}$. GE do Brás (15/08/1898), o GE da Bela Vista (04/07/1900), o GE do Triunfo (03/09/1900), o GE da Barra Funda (10/03/1903), o GE da Liberdade (01/09/1905) e o GE do Pari (13/03/1905). Mais tarde, foram os bairros mais afastados do centro aqueles beneficiados com grupos escolares, de que são exemplos o GE da Lapa, o GE da Vila Mariana, o GE de Santana e o GE da Penha, que começaram a funcionar, respectivamente, em 08/02/1909, 26/03/1909, 17/05/1909 e 24/09/1913. Dessa forma, ao que tudo indica, a administração pública buscou a princípio contemplar os bairros onde era maior o adensamento populacional, como era o caso daqueles próximos ao centro. $\mathrm{O}$ processo de modernização realizado pelo prefeito Antonio Prado, porém, levou à diminuição demográfica dessa parte da cidade e, logo, era preciso espalhar os grupos escolares para os novos locais onde passou a habitar a população escolar.

Quanto ao interior, foram implantados 77 grupos escolares, entre 1898 e 1910. Desse ano até 1919, o número dessas escolas duplicou e não parou de aumentar, passando de 154 a 250, em 1929. A distribuição geográfica dos grupos escolares pelo Estado foi pautada pelo deslocamento populacional, movimento que, como antes assinalado, era engendrado pelo auge e decadência das zonas de cultivo do café. No período 1894-1900, por exemplo, dos 38 grupos escolares existentes, 13 foram instalados no Vale do Paraíba, 13 na Central, 7 na Mogiana, 2 na Alta Sorocabana, 1 na Baixa Paulista, 1 na Baixa Sorocabana e 1 em Santos. Desse modo, os grupos escolares foram primeiramente estabelecidos nos municípios

${ }^{62}$ A partir dela, o curso primário passou a durar dois anos e devia ser ministrado nos grupos escolares, nas escolas isoladas e nas escolas reunidas. Mais detalhes sobre a Reforma serão expostos posteriormente. 
localizados nas chamadas zonas antigas, a saber, Vale do Paraíba, Central e Mogiana e, mais tarde, naqueles situados nas zonas pioneiras. Utilizando como critério a data de inauguração, os dez mais antigos grupos escolares são: o GE de Iguape (07/01/1894 - Mogiana); o GE de São Roque (24/09/1894 - Central); o $1^{\circ}$. GE de $\operatorname{Amparo}^{63}$ (04/10/1894 - Mogiana); o GE de Itu (15/10/1894 - Central); o GE de Tietê (15/10/1894 - Central); o GE de Itapetininga (14/01/1895 - Central); o GE de Guaratinguetá (24/01/1895 - Vale do Paraíba); o GE de Pindamonhangaba (24/01/1895 - Vale do Paraíba); o GE de Franca (03/05/1895 - Mogiana) e o GE de Lorena (03/06/1895 - Vale do Paraíba).

Se comparados, o incremento da rede de grupos escolares na cidade de São Paulo foi menor do que o do interior, o que foi provocado pelo início, em 1908, do desdobramento, ou seja, o funcionamento em dois turnos, solução encontrada para atender a contínua demanda por vagas sem o dispêndio de recursos: manhã (8:00 às 12:00, para os meninos) e tarde (12:30 às 16:30, para as meninas). À guisa de ilustração, em 1919, o desdobramento já estava em curso em 28 dos 31 grupos escolares da Capital. No interior, a política de substituir a instituição de novas escolas pelo crescimento interno das mesmas, apesar de mais lentamente, não deixou de ser colocada em prática, atingindo, no mesmo ano, 107 dos 156 grupos escolares. Como conseqüência do desdobramento, o número de classes, na cidade de São Paulo, quase dobrou de 1910 a 1919 (de 355 para 660) e, no interior, mais do que duplicou no mesmo período (de 807 para 1857) (Antunha, 1976).

No que tange às matrículas, o quadro a seguir, disposto nos Anuários do Ensino de 1916 mostra que o total das mesmas (Capital e interior) manteve-se crescente entre 1898 e 1916, exceto por uma pequena queda em 1904, no número de meninos:

TABELA 4

\begin{tabular}{|c|c|c|c|}
\hline Ano & Sexo feminino & Sexo masculino & Total \\
\hline 1898 & 5.319 & 6.134 & 11.453 \\
\hline 1899 & 5.908 & 6.647 & 12.565 \\
\hline 1900 & 6.754 & 8.526 & 15.280 \\
\hline 1901 & 7.372 & 9.468 & 16.840 \\
\hline 1902 & 9.454 & 9.898 & 19.252 \\
\hline 1903 & 10.019 & 11.654 & 21.673 \\
\hline 1904 & 10.100 & 10.589 & 20.689 \\
\hline 1905 & 11.083 & 11.696 & 22.779 \\
\hline 1906 & 11.971 & 12.565 & 24.536 \\
\hline 1907 & 12.220 & 13.278 & 25.498 \\
\hline
\end{tabular}

${ }^{63}$ Até os anos de 1920, poucas localidades dispunham de mais de um grupo escolar. Em 1908, por exemplo, Amparo já possuía dois grupos escolares, como também era o caso de Jundiaí, Campinas, Piracicaba e Santos (Souza, 1997). 


\begin{tabular}{|l|l|l|l|}
\hline 1908 & 14.794 & 15.666 & 30.460 \\
\hline 1909 & 20.046 & 21.229 & 41.275 \\
\hline 1910 & 26.201 & 27.244 & 53.445 \\
\hline 1911 & 30.971 & 32.059 & 63.030 \\
\hline 1912 & 34.460 & 35.380 & 70.051 \\
\hline 1913 & 38.117 & 38.606 & 76.723 \\
\hline 1914 & 44.178 & 45.546 & 89.724 \\
\hline 1915 & 46.893 & 49.738 & 96.631 \\
\hline 1916 & 46.914 & 49.492 & 96.406 \\
\hline
\end{tabular}

De 1917 a 1929, a matrícula geral nos grupos escolares permaneceu em ascensão (Costa, 1983). Embora isso pouco significasse, devido à escassez de informações disponíveis sobre a freqüência efetiva das crianças (Antunha, 1976), as estatísticas relativas às matrículas não deixam de ser importantes, ao contribuírem para revelar quem eram as crianças que se sentavam nos bancos desse tipo de escola primária, como ressalta Souza (1997, p.98):

\begin{abstract}
A Inspetoria Geral do Ensino não se preocupou em recolher dados sobre as condições sociais dos alunos das escolas públicas, embora exercesse controle sobre matrícula, freqüência e promoção. (...) Os únicos dados referentes às características dos alunos, solicitados pela Inspetoria, diziam respeito à média das idades e a nacionalidade. O primeiro deles se explica pela observância da obrigatoriedade escolar e pela preocupação com a homogeneização das classes - elemento fundamental nas escolas graduadas. O segundo refere-se à nacionalidade e às políticas de nacionalização da população imigrante.
\end{abstract}

Por meio da tabela anterior, é possível entrever que a proporção de meninos e de meninas era praticamente equilibrada. Isso sinalizava que, a despeito dos preconceitos em vigor à época - dos quais a ausência da co-educação era um nítido exemplo - os grupos escolares significaram a oportunidade para o início da escolarização feminina. No que diz respeito à nacionalidade das crianças matriculadas nos grupos escolares de todo o Estado ${ }^{64}$, os Anuários do Ensino de 1909 trazem os seguintes dados:

TABELA 5

\begin{tabular}{|c|c|c|c|c|c|c|c|c|}
\hline Brasileiros & Italianos & Portugueses & Espanhóis & Alemães & Franceses & Árabes & Ingleses & Outros \\
\hline 39.501 & 1.088 & 333 & 135 & 27 & 23 & 57 & 14 & 97 \\
\hline
\end{tabular}

Eram estrangeiros, pois, 1.774 dos 41.275 alunos. Desse total, a nacionalidade majoritária era a italiana, seguida pela portuguesa e pela espanhola, proporção semelhante à encontrada na população geral, ao menos na cidade de São Paulo. Além disso, 25.157 e 16.118 eram as crianças que tinham, respectivamente, pais brasileiros e pais imigrantes. Em 1920, conforme os Anuários do Ensino de 1920-1921, o número de alunos brasileiros ainda

\footnotetext{
${ }^{64}$ Foi incluída a Escola-Modelo "Caetano de Campos”.
} 
superava àquele formado pelos não nacionais, tanto na Capital quanto no interior. No entanto, na cidade de São Paulo, eram filhos de imigrantes 21.934 dos 31.336 alunos matriculados, o que representava mais do que o dobro daqueles cujos pais eram nacionais. Levando-se em conta ainda a soma geral das crianças matriculadas nos grupos escolares do Estado, de 120.527, a porcentagem de descendentes de estrangeiros havia subido em relação a 1909, ultrapassando os 50\%:

TABELA 6

\begin{tabular}{|c|c|c|c|c|}
\hline & $\begin{array}{c}\text { Alunos } \\
\text { brasileiros }\end{array}$ & $\begin{array}{c}\text { Alunos } \\
\text { estrangeiros }\end{array}$ & $\begin{array}{c}\text { Filhos de } \\
\text { pais brasileiros }\end{array}$ & $\begin{array}{c}\text { Filhos de } \\
\text { pais estrangeiros }\end{array}$ \\
\hline Capital & 28.831 & 2.505 & 9.402 & 21.934 \\
\hline Interior & 86.710 & 2.481 & 49.952 & 39.939 \\
\hline Total & 115.541 & 4.986 & 59.354 & 61.873 \\
\hline
\end{tabular}

A presença de alunos com filiação estrangeira era expressiva na maioria dos grupos escolares da Capital, mormente naqueles situados em bairros operários. O escritor e jornalista Lourenço Diaféria, nascido no Brás, lembra que nele os "italianos chegaram em tamanha quantidade (...) que houve uma época que cada dois pedestres que se encontravam numa esquina um era italiano; o outro não era, mas parecia ser" (2002, p.155). Ainda nas palavras do autor, o $1^{\circ}$. Grupo Escolar do bairro, mais tarde denominado Romão Puiggari em homenagem a um de seus diretores, foi "um dos orgulhos do Brás. (...) As milhares de pessoas que olham o prédio, supondo-se que olhem, devem confundi-lo com uma massa de concreto sem nenhuma ligação com a história do bairro e nem imaginam a importância que teve, e tem, para a formação de toda região" (2002, p.62). Os dados abaixo foram calculados a partir dos

\section{Anuários do Ensino de 1918:}

TABELA 7

\begin{tabular}{|c|c|c|c|}
\hline Grupo Escolar & $\begin{array}{c}\text { Filhos de } \\
\text { pais brasileiros }\end{array}$ & $\begin{array}{c}\text { Filhos de } \\
\text { pais estrangeiros }\end{array}$ & $\begin{array}{c}\text { Filiação } \\
\text { estrangeira (\%) }\end{array}$ \\
\hline Barra Funda & 1.118 & 1.118 & 50 \\
\hline Bela Vista & 205 & 726 & 78 \\
\hline Brás (1 ${ }^{\mathbf{0}}$.) & 302 & 1.541 & 83,6 \\
\hline Mooca & 86 & 939 & 91,6 \\
\hline
\end{tabular}

Também no interior a participação de crianças provenientes de famílias estrangeiras era alta, embora em menor proporção, considerando-se as estatísticas baseadas nos Anuários do Ensino publicados no período 1912-1916: 
TABELA 8

\begin{tabular}{|c|c|c|c|}
\hline Ano & $\begin{array}{c}\text { Filhos de pais } \\
\text { brasileiros }\end{array}$ & $\begin{array}{c}\text { Filhos de pais } \\
\text { estrangeiros }\end{array}$ & Filiação estrangeira (\%) \\
\hline 1912 & 29.022 & 17.221 & 37 \\
\hline 1913 & 13.189 & 7.391 & 36 \\
\hline 1914 & 40.048 & 24.497 & 38 \\
\hline 1915 & 43.710 & 25.562 & 37 \\
\hline 1916 & 39.623 & 29.077 & 42,3 \\
\hline
\end{tabular}

A nacionalidade e a filiação dos alunos matriculados nos grupos escolares do Estado de São Paulo refletiam o contexto histórico. Com efeito, à época, muitos estrangeiros se dedicavam às atividades urbanas: no que se referia à Capital, se os italianos eram empregados sobretudo pelas indústrias, os portugueses trabalhavam como artesãos, pedreiros, pintores, carpinteiros, serralheiros, marceneiros, marmoristas, donos de pequenos armazéns de secos e molhados, de açougues, de adegas, de quitandas e de botequins. Já os espanhóis tornaram-se carroceiros, cocheiros, empregados de bares, restaurantes e hotéis, bem como recolhiam nas ruas materiais para serem reaproveitados (Hall, 2004a). A instauração dos grupos escolares representou, assim, parte fundamental das políticas de nacionalização da população estrangeira residente no Estado de São Paulo (Souza, 1997). Para integrá-la à sociedade brasileira, o instrumento mobilizado pelo poder público consistiu nos programas de ensino, como será visto depois.

No que circunscreve às condições sócio-econômicas das crianças cujos pais eram brasileiros, há indícios de que a procura pelos grupos escolares partiu de todas as camadas sociais, mesmo daquelas mais favorecidas, como deixa entrever, por exemplo, o relatório escrito pelo inspetor escolar Francisco Pedro do Canto, em 1900:

Na nossa humilde opinião a escola publica deveria constituir o 'apanagio do pobre' daqueles que não tiveram meios de mandar seus filhos a uma escola particular (...). O contrario, porem, sejamos permittidos dizer, se observa nesta Capital, onde a maior parte dos collegios fallecem a mingua de alumnos, porque aqueles que poderiam mandar a eles preferem pol-os nas Escolas-modelo e nos Grupos escolares sem despesa alguma e onde muitas vezes são preferidos aos filhos do proletário.

No interior, o papel dos grupos escolares como instituições de educação popular também foi questionado. Segundo Souza (1997), no início do século passado, alguns pais queixaram-se de que o diretor do $1^{\circ}$. Grupo Escolar de Campinas priorizava as vagas para filhos de famílias ricas. Além disso, a autora notou que, no $2^{\circ}$. Grupo Escolar da mesma cidade, onde a proporção de crianças estrangeiras era de 52,08\%, apesar das profissões dos 
pais dos alunos da seção masculina abrangerem uma gama variada, nela predominava aquelas vinculadas ao setor do comércio, seguidas pelo dos transportes e, em terceiro lugar, pelo da indústria. A despeito de tais dados não poderem ser generalizados para todos os grupos escolares do Estado, eles permitem supor de que nos mesmos conviviam crianças de diferentes origens sociais embora fossem, em geral, filhos de pais que se situavam em posições privilegiadas no mercado de trabalho urbano, sendo, então, pouco perceptível o acesso de pobres e de negros ${ }^{65}$ (Souza, 1997).

\subsubsection{As escolas isoladas: a outra face da modernização}

Em bôa hora, não se poupando sacrificios, resolveu o Governo do Estado empregar uma verba (...) para a acquisição de predios destinados a Grupos Escolares, na Capital e no Interior. Oxalá que alguma sóbra daquella quantia fosse tambem applicada na construcção de casas escolares, em localidades cuja população infantil, não sendo sufficiente para manter um grupo escolar, garantisse, entretanto, a estabilidade de frequencia nas escolas isoladas existentes. Só assim desappareceriam de nossas cidades e bairros esses vergonhosos casébres sem espaço, sem ar, sem luz, sem attractivo algum para as creanças, e que constituem formal desmentido aos nossos foros de povo progressista em materia de hygiene e de instrucção publica.

Antonio Morato de Carvalho (inspetor escolar, nos Anuários do Ensino do Estado de São Paulo de 1910-1911)

Enquanto se propagava a imagem positiva dos grupos escolares, um outro tipo de escola era severamente criticado pelas autoridades educacionais, em relação aos mais diversos aspectos. Localizadas quase sempre em regiões pobres e de difícil acesso, as escolas isoladas consistiam nas escolas de primeiras letras legadas do Império, nas quais o mesmo professor lecionava para crianças de diferentes idades e níveis de adiantamento. O termo "escolas isoladas" surgiu com a Lei n. 930, de 13 de agosto de 1904, para distingui-las dos grupos escolares, uma vez que elas permaneceram onde não era possível a instalação daqueles (Antunha, 1976). Antes disso, elas eram denominadas de escolas preliminares. De acordo com o Decreto n. 1239, que regulamentou a Lei n. 930, as escolas isoladas eram classificadas em

\footnotetext{
${ }^{65}$ A exclusão dos negros dos grupos escolares denota a difícil adaptação deles à vida pós-abolição. Com efeito, os afro-descendentes tiveram de disputar com os estrangeiros as oportunidades de trabalho. Isso porque, para as camadas dominantes, o europeu era o tipo ideal de trabalhador: enquanto ele vinha de um mundo a ser tomado como modelo, supostamente internalizava valores e comportamentos esperados, tais como a ordem do trabalho, a honradez, a honestidade, a moralidade, a operosidade e a eficiência.
} 
escolas de bairros ou de distritos de paz, ou seja, aquelas situadas "fóra do perimetro urbano da séde do municipio, estejam ou não sujeitos ao pagamento do imposto predial" (Artigo $3^{\circ}$.) e em escolas de sede de municípios. Tratavam-se, nesse caso, de

escolas do municipio da Capital e as das sédes dos outros municipios do Estado, sendo como taes consideradas as escolas situadas no perimetro urbano, embora em logares denominados bairros, uma vez que estes sejam parte integrante da cidade, estejam sujeitos ao pagamento do imposto predial e sejam pelo Governo declarados parte da séde do municipio (Artigo $4^{\mathrm{o}}$.).

Se comparada com a expansão dos grupos escolares, a quantidade de escolas isoladas criadas foi mais modesta. De fato, ao passo em que o crescimento das escolas graduadas foi constante ao longo do período 1898-1929, o das escolas isoladas foi caracterizado pela instabilidade, uma vez que foi comum o acréscimo ser seguido pela retração, particularmente entre 1896 e 1904 (Costa, 1983). A exceção foi o intervalo 1910-1916, no qual o número de escolas isoladas mais do que dobrou, passando de 86 para 193. No que tange à distribuição geográfica das escolas isoladas, os dados indicam que a região do Vale do Paraíba concentrou 51,8\% dos estabelecimentos inaugurados no interior do Estado no decênio 1890-1899. Seguindo a rota do café, todavia, de 1900 a 1919 a zona Noroeste e Alta Paulista passou a deter $86,9 \%$ do total de escolas isoladas do Estado, excluindo-se aquelas da Capital (Costa, 1983). Também no interior, a matrícula geral era superior à da cidade de São Paulo, possivelmente porque nela havia menos escolas isoladas, as quais foram espalhadas pelos mais diferentes bairros, como Sé, Liberdade, Santa Ifigênia, Barra Funda, Belenzinho, Bela Vista, Butantã, Brás, Bom Retiro, Consolação, Cambuci, Santa Cecília, Lapa, Vila Mariana, Penha, São Miguel, Mooca e Santana (Marcílio, 2005). Quanto à proporção de meninos e meninas matriculados, o quadro a seguir, extraídos dos Anuários do Ensino do Estado de São Paulo de 1917, mostra o predomínio dos primeiros nas escolas isoladas do Estado, o que pode ser explicado pela inclusão do público majoritariamente masculino das escolas e dos cursos noturnos, existentes sobretudo na Capital (Antunha, 1976):

TABELA 9

\begin{tabular}{|c|c|c|c|}
\hline Ano & Sexo feminino & Sexo masculino & Total \\
\hline 1898 & 13.235 & 18.333 & 31.568 \\
\hline 1899 & 14.117 & 19.895 & 34.012 \\
\hline 1900 & 6.609 & 8.942 & 15.551 \\
\hline 1901 & 6.864 & 8.645 & 15.509 \\
\hline 1902 & 8.308 & 11.593 & 20.901 \\
\hline 1903 & 8.028 & 10.646 & 18.674 \\
\hline 1904 & 12.781 & 13.326 & 26.107 \\
\hline 1905 & 13.218 & 14.115 & 26.333 \\
\hline
\end{tabular}




\begin{tabular}{|l|l|l|l|}
\hline 1906 & 13.907 & 15.288 & 29.195 \\
\hline 1907 & 17.450 & 17.473 & 34.923 \\
\hline 1908 & 18.853 & 19.299 & 38.152 \\
\hline 1909 & 18.948 & 19.171 & 39.194 \\
\hline 1910 & 20.908 & 24.850 & 45.758 \\
\hline 1911 & 24.155 & 27.376 & 51.531 \\
\hline 1912 & 23.134 & 29.540 & 52.684 \\
\hline 1913 & 25.989 & 31.199 & 57.188 \\
\hline 1914 & 24.121 & 34.017 & 58.138 \\
\hline 1915 & 24.396 & 36.462 & 60.858 \\
\hline 1916 & 24.576 & 37.727 & 63.603 \\
\hline
\end{tabular}

A maior presença de meninos estava, ao que parece, vinculada à superioridade numérica das escolas isoladas masculinas em comparação às femininas e às mistas, entre 1890 e 1905. A partir desse ano, as primeiras, cuja contribuição girava em torno dos $50 \%$, foram gradativamente sendo suplantadas pelas escolas mistas localizadas nos bairros, criadas numa quantidade que chegou a ultrapassar a soma das escolas femininas e das masculinas, de 1915 a 1919 (Costa, 1983).

Em 1913, através do Decreto n. 2368, de 14 de abril de 1913, que aprova o Regulamento das escolas de bairros, as escolas isoladas passaram a ser denominadas de escolas de bairro e a duração de seu curso - que já era menor do que aquele das escolasmodelo e dos grupos escolares, de 4 anos - passou de 3 para 2 anos:

Art. $1^{\circ}$. - São escolas de bairros as escolas preliminares situadas nos centros agrícolas, povoados ou districtos de paz; Art. $2^{\circ}$. - Estas escolas são classificadas em duas categorias: são as de primeira categoria as que distam menos de 20 kilometros de uma estação de estrada de ferro; são as de segunda as demais.

A supressão de um ano do curso das escolas isoladas deixa claro que, para o Estado, se era preciso reduzir custos, que as escolas isoladas fossem as primeiras a serem atingidas. Outra medida nesse sentido que acabou por desfavorecer as escolas isoladas era o fato de que o aluguel da escola cabia ao próprio professor que, recebendo vencimentos baixos se comparados aos daqueles que trabalhavam nos grupos escolares, não podia arcar com despesas altas. Como resultado, as escolas isoladas funcionavam precariamente, em locais onde, com freqüência, não havia condições mínimas de higiene. Além dos relatórios dos inspetores escolares, fartos em apontar a penúria das escolas isoladas, o livro O calvário de uma professora ${ }^{66}$ (1927) descreve a experiência da professora Hermengarda nessa modalidade de escola:

\footnotetext{
${ }^{66}$ A obra, de autoria de Dora Lice (pseudônimo de Violeta Leme), foi um dos quatro romances escritos por professores paulistas de 1920 a 1935 analisados por Moraes (1996) em sua dissertação de mestrado. Em O
} 
Quinze, vinte dias!... O material escolar não chegava!

No desconforto de sua sala de aula tinha Hermengarda para reanimar-lhe a energia, estimula-la ao trabalho, aquelles olhosinhos infantis, tão vivos e meigos, postos sobre ella, como a pedir-lhe instrucção.

Então se punha a trabalhar corajosamente, mas em vão se exgottava. As crianças pouco aprendiam.

Não havia quadros negros. Sua mesa era um caixão. O livro de chamada, uma folha de papel. Phosphoros faziam as vezes de tornos (DORA LICE, 1927, p.40).

Sem o fornecimento de móveis e de material didático, o trabalho dos professores das escolas isoladas ficava seriamente prejudicado, o que as tornava pouco atrativa para eles. A tabela abaixo, produzida a partir dos Anuários do Ensino de 1917 e de Antunha (1976), assinala o número de escolas isoladas providas na Capital e no Interior, entre 1898 e 1925 :

TABELA 10

\begin{tabular}{|c|c|c|c|}
\hline Ano & Capital & Interior & Total \\
\hline 1898 & 66 & 1.084 & 1.150 \\
\hline 1899 & 82 & 968 & 1.050 \\
\hline 1900 & 85 & $149^{67}$ & 534 \\
\hline 1901 & 108 & 521 & 629 \\
\hline 1902 & 110 & 692 & 702 \\
\hline 1903 & 114 & 502 & 616 \\
\hline 1904 & - & - & 730 \\
\hline 1905 & - & - & 865 \\
\hline 1906 & - & - & 1.006 \\
\hline 1907 & 129 & 993 & 1.122 \\
\hline 1908 & 145 & 1.176 & 1.321 \\
\hline 1909 & 103 & 1.230 & 1.333 \\
\hline 1910 & 86 & 1.121 & 1.207 \\
\hline 1911 & 116 & 955 & 1.071 \\
\hline 1912 & 144 & 1.048 & 1.192 \\
\hline 1913 & 187 & 1.025 & 1.212 \\
\hline 1914 & 173 & 1.039 & 1.212 \\
\hline 1915 & 182 & 1.232 & 1.414 \\
\hline 1916 & 193 & 1.362 & 1.555 \\
\hline 1917 & 183 & 1.421 & 1.604 \\
\hline 1918 & 176 & 1.394 & 1.570 \\
\hline 1919 & 134 & 1.408 & 1.562 \\
\hline 1920 & 130 & 1.453 & 1.783 \\
\hline 1921 & 120 & 1.477 & 1.597 \\
\hline 1922 & 74 & 1.447 & 1.521 \\
\hline 1923 & 61 & 1.502 & 1.563 \\
\hline 1924 & 54 & 1.451 & 1.501 \\
\hline 1925 & 77 & 1.251 & 1.328 \\
\hline & & & \\
\hline
\end{tabular}

calvário de uma professora "a narradora onisciente conta a história de vida da personagem Hermengarda, professora primária em escola isolada e grupos escolares no interior de São Paulo (...). O romance está estruturado em função de um interesse específico: demonstrar à sociedade as reais condições de trabalho da professora primária (...). O recurso à ficção é adotado para defender uma posição política” (Moraes, 1996, p.45).

${ }^{67} \mathrm{O}$ número reduzido de escolas providas deveu-se à passagem de 516 delas para as Câmaras Municipais, conforme a Lei n.686, de 16 de setembro de 1899, e à criação de grupos escolares que absorveram as escolas locais. 
Em 1904, 1909 e 1914, por exemplo, o número de escolas criadas era, respectivamente, de 2.591 , de 3.024 e de 3.797 , mas, em todos os casos, nem a metade delas foi provida com professores. Com o decorrer dos anos, a proporção de escolas vagas aumentava ainda mais: em 1927, ela era de 37,6\%, já que, entre 4.263 escolas, somente 1.604 tinham professores. A situação era mais grave nas escolas isoladas das zonas rurais do que naquelas das sedes de municípios. Enquanto a média de provimento das primeiras era de $25 \%$, cerca de dois terços das segundas atendiam crianças (Costa, 1983), o que sinalizava a preferência dos professores pelas áreas urbanas. As tentativas por parte do Estado em reverter o quadro pouco surtiram efeito. Uma delas foi obrigar os mestres recém-formados à permanência de um ano nas escolas isoladas localizadas em bairros ou em distritos de paz, antes de pedirem a remoção para as escolas isoladas de sede de município. Nessas, por sua vez, era preciso exercer a docência por dois anos antes da transferência para as escolas isoladas da Capital e para grupos escolares de qualquer região (Souza, 1997). Em relatório apresentado ao Secretário dos Negócios do Interior e publicado nos Anuários do Ensino de 1907-1908, o então Inspetor Geral do Ensino, João Lourenço Rodrigues, destacava que, nas escolas suburbanas, ou seja, de bairros e distritos de paz, os professores "não permanecem sinão o tempo marcado para a promoção, tempo inteiramente insufficiente para ensinar a lêr aos seus alumnos. O tempo de bairro é considerado como um prazo de desterro. Terminado elle, o professor se remove, e os materiaes da escola se extraviam ou deterioram" (p.27). Desse modo, às escolas isoladas dirigiam-se professores inexperientes que, não podendo contar com o acompanhamento das autoridades escolares, que pouco as visitavam, desenvolviam um trabalho extremamente solitário. Ademais, a maioria deles era diplomada pelos cursos complementares, onde a formação recebida era inferior àquela dada pela Escola Normal (Tanuri, 1979).

Além dos professores, desmotivados a trabalhar nas escolas isoladas, a baixa assiduidade dos alunos, ao ver dos inspetores escolares, era um dos principais problemas que era preciso enfrentar, como argumenta Antonio Morato de Carvalho, nos Anuários do Ensino

\section{de 1909-1910:}

Necessidade que cumpre ainda prover, com relação ao exercicio dos professores é garantir-lhes a frequencia nas escolas para que foram nomeados, de modo a preserval-os contra a desidia de certos paes que, preferindo o lucro pecuniario para seus filhos, descuram do dever de instruil-os. Isto se dá mormente nas localidades agricolas onde ao tempo do plantio e da colheita, a frequencia regulamentar dos alumnos torna-se duvidosa, pondo em embaraço os professores, para conseguirem mensalmente a média legal (p.242). 
Para outro inspetor escolar, Maurício de Camargo, incentivar a comunidade rural a ir à escola era tarefa do próprio professor da escola isolada, mas para a qual era imprescindível que ele fixasse residência nas proximidades do estabelecimento, até mesmo para evitar atrasos e/ou saídas antecipadas:

Si não tratar o professor de relacionar-se com os morados do bairro, não poderá contar com a sua collaboração na tarefa educativa que lhe cabe, nem mesmo exercer nenhuma influencia benéfica sobre os costumes.

Não compreende a população rural a vantagem da escola, e jamais o compreenderá, si continuar o mal fadado costume de não residir o professor na séde de sua escola e continuar nesse vem e vem incessante; preso ao apito dos trens, e inteiramente despreoccupado de sua missão (p.XCIII).

A idéia de que, sendo pobres, alguns pais afastavam os filhos da escola para que pudessem auxiliar no campo, levou à criação da Lei n. 1579, de 19 de dezembro de 1917, a fim de assegurar ao menos a alfabetização deles (Gallego, 2003). Para isso, as escolas isoladas foram divididas "em ruraes, districtaes e urbanas" (Art. $1^{\circ}$.), cuja duração do curso era, respectivamente, de 2, 3 e 4 anos. As primeiras estavam "localisadas nas propriedades agricolas, nos nucleos coloniaes e nos centros fabris distantes da séde de município" (Art. $2^{\circ}$.), as segundas "em bairros ou séde de districto de paz" (Art. $3^{\circ}$.) e as últimas eram "as creadas em séde do município" (Art. $4^{\circ}$.). Contudo, a partir do Decreto n. 3356, de 31 de maio de 1921, que regulamentou a Reforma Sampaio Dória, as escolas isoladas passaram a ser "classificadas em urbanas e ruraes" (Art. 95), ambas de 2 anos de duração. As primeiras consistiam nas escolas "do municipio da Capital"; "da séde dos outros municípios, situadas em logares sujeitos a imposto predial urbano"; "da séde dos districtos de paz" (Art. $95 \S 1^{\circ}$.). Já as rurais eram "as demais escolas isoladas" (Art. $95 \S 2^{\circ}$.). Por fim, as "actuaes escolas districtaes, quando vagarem, serão classificadas como urbanas ou ruraes, segundo a zona onde houverem de funccionar" (Art. 96).

Dois trabalhos baseados na vivência de professores em escolas isoladas, entretanto, contradizem as opiniões dos inspetores escolares sobre a resistência das populações rurais à escolarização. Um deles é o romance $\mathbf{O}$ calvário de uma professora, no qual a autora conta que a professora Hermengarda não precisou convencer os pais do valor da escola:

Hermengarda pôs-se a trabalhar (...).

Alumnas não lhe faltaram. Em tres dias matriculou sessenta. Era mais que a lotação da sala, mas não havia um regulamento escolar ou pessoa competente para a orientar.

As creanças levavam de casa, compridos bancos, que eram enfileirados ao longo das paredes.

Quando a professora, recusava alumnas, por falta de logar, retrocavam logo os paes: 

'A

Por sua vez, Demartini; Tenca, S.; Tenca, A. (1985), a partir de entrevistas com professores que lecionaram em escolas públicas do interior paulista destinadas às populações rurais, puderam contestar "a ideologia que se pretendia inculcar; isto é, os problemas de freqüência não eram comuns como se queria supor, e, quando existiam, dependiam muito menos da vontade dos pais, que das condições objetivas em que se realizava o trabalho agrário, principalmente nas fazendas" (1985, p.63). Isso significava que as faltas eram mais comuns nas escolas localizadas nas propriedades rurais, freqüentadas por filhos de colonos, do que naquelas instaladas nos bairros, vilas ou pequenos povoados, cuja clientela era formada especialmente pelos filhos de sitiantes, em situação econômica melhor do que os primeiros. Segundo os professores, os transtornos decorrentes das ausências das crianças eram por eles contornados, ou seja, seu rendimento escolar não era comprometido, tendo em vista que a maioria delas era aprovada nos exames finais (Demartini; Tenca, S.; Tenca, A., 1985).

É possível concluir, nesse sentido, que a alegada indiferença das populações rurais pela escola foi utilizada, pelo poder público, como artifício para justificar a pouca atenção dada às escolas isoladas. Afinal, para que o dispêndio de recursos com novas escolas e/ou a manutenção daquelas em funcionamento se não havia qualquer desejo de escolarização por parte desses segmentos sociais? Impulsionada por esse pressuposto, a expansão desse tipo de escola primária não foi capaz de suprir a ampla procura por ele e, mais do que isso, acabou por configurar-se mais como um favor que se prestava à população do que como um direito. De fato, Demartini (1989b) ressalta que, ao longo da Primeira República, foi considerável a influência da política local no sistema educacional primário. Cientes da forte demanda pela escola, os coronéis passaram a incluí-la como um elemento de barganha com seu eleitorado, tanto nas fazendas quanto nas pequenas cidades e vilas. No caso das primeiras, a existência de uma escola agregava valor a elas e ainda servia como atrativo para a vinda e fixação de colonos. Ao mesmo tempo, a escola passou a representar mais uma das instituições que podiam ser controladas pelos chefes políticos locais. Para isso, eles não se importavam em abrir escolas mesmo onde não havia número suficiente de crianças ou então em nomear, para nelas lecionar, professores com os quais tinham algum parentesco ou que lhes prometia apoio político.

Além das escolas isoladas dependerem dos interesses políticos em jogo para serem instaladas, as providências para sua melhoria eram sempre postergadas ou simplesmente 
fadadas ao esquecimento. Isso porque, no âmbito do processo de modernização educacional organizado pelas elites, as escolas isoladas, longe de constituírem expressão do progresso, como as escolas-modelo e os grupos escolares, foram concebidas como um dos muitos vestígios do passado imperial que se buscava superar. Enquanto tais, elas eram motivo de vergonha e de incômodo, o que as levou a receber um "chocante (...) tratamento inferior" (Antunha, 1976, p.69). Contraditoriamente, era esse tipo de escola primária aquele considerado como o mais problemático e, por isso, mais carecia de investimento. Ademais, ao privilegiar a visibilidade pública proporcionada pelas escolas urbanas, o Estado acabou por marginalizar largas parcelas da população paulista, levando em conta que, à época, a maioria dela - formada por nacionais e por imigrantes - ainda residia no campo ${ }^{68}$.

\subsubsection{As escolas-modelo isoladas: pouco conhecidas}

No que concerne a esse tipo de escola primária, há poucas informações disponíveis, tanto nos documentos produzidos no primeiro período republicano, quanto nos estudos históricos sobre o mesmo. O relatório de João Lourenço Rodrigues incluído nos Anuários do Ensino do Estado de São Paulo de 1907-1908, todavia, contribui para elucidar o contexto de criação das escolas-modelo isoladas. Segundo o então Inspetor Geral do Ensino, seria impensável exigir que as escolas-modelo servissem de padrão às escolas isoladas, tal como devia ocorrer em relação aos grupos escolares. Sendo discrepantes as condições de funcionamento das duas modalidades de escolas, Rodrigues sugeria a instituição da escolamodelo isolada em duas seções, uma masculina e a outra feminina, cuja organização caberia à Diretoria da Escola Normal. Nesse novo estabelecimento de ensino, seriam postas em prática todos os aspectos da cultura escolar a serem generalizados depois em todas escolas isoladas do Estado:

Creada a nova escola-modelo e organisada sobre estas bases, os resultados nella obtidos fornecerão indicações seguras para a futura regulamentação das escolas isoladas (...).

Programmas, horarios, duração do curso e das aulas, etc., tudo ficará assentado ali, depois da necessaria experiencia.

Elaborado o regimento interno da escola-modelo isolada, o governo poderá tornal-o extensivo ás escolas isoladas em geral, como é extensivo aos grupos o regimento da escola-modelo actual.

\footnotetext{
${ }^{68}$ Não foi possível reunir dados significativos sobre a nacionalidade das crianças que freqüentavam as escolas isoladas.
} 
Como vêdes, trata-se de uma medida de grande alcance, porque diz respeito á vida interna de mais de 1200 escolas disseminadas hoje por todo o Estado (p.31-32).

O Decreto n. 1577, de 21 de fevereiro de 1908, oficializou as idéias acima, definindo que: “Art. $1^{\circ}$. - Fica creada uma Escola Modelo, que servirá de padrão ás escolas isoladas, do mesmo modo que a Escola Modelo atual serve de padrão aos grupos escolares”. O Decreto n. 2004, de 13 de fevereiro de 1911, por sua vez, aprovou o Regimento Interno desse tipo de escola primária, acrescentando que ele se destinava: "b) ao ensaio e aperfeiçoamento dos methodos e processos de ensino que deverão ser adoptados no ensino publico preliminar do Estado; c) á practica e observação dos alumnos da Escola Normal de São Paulo" (Art. $2^{\circ}$.). Além disso, a "frequencia dessas escolas será permittida ás crianças de 7 annos em deante, guardadas as restrições de legislação escolar em vigor" (Art. $4^{\circ}$.).

Sobre a expansão das escolas-modelo isoladas, foi possível identificar apenas, nos Anuários do Ensino de 1920-1921, que, à época, 4 delas estavam estabelecidas na Capital e 16 no interior do Estado. Conforme as mesmas publicações do período 1907-1908, no dia 29 de abril de 1908, a Capital foi palco da abertura das duas primeiras classes, uma para cada sexo, que funcionavam

em dois predios contiguos situados ao largo do Arouche ns. 58 e 60, onde, até ha pouco, estiveram localisadas as escolas do $8^{\circ}$. districto.

Os dois edificios escolares, que pertencem ao Estado por doação feita pelo fallecido dr. Rego Freitas, offerecem amplas acommodações e preenchem a todos os requisitos pedagogicos.

(...) A regencia das duas classes está confiada aos professores D. Lavinia Barbosa e Theodoro Rodrigues de Moraes.

Acham-se matriculadas 91 crianças, sendo 46 meninas e 45 meninos (p.121-122).

\subsubsection{As escolas reunidas e sua trajetória singular}

Foram admiráveis os resultados advindos com a disseminação, em larga escala, das escolas reunidas; ellas resolveram o problema do ensino, com grande sucesso, sob dois pontos de vista basicos: Economia e aproveitamento.

Anuários do Ensino do Estado de São Paulo de 1923

As escolas reunidas passaram a fazer parte do sistema público primário paulista por meio do Decreto n. 2225, de 16 de abril de 1912. Essa nova modalidade de escola seria instalada “a) Nas sédes de municipio cuja população escolar for insufficiente para a criação de 
um grupo-escolar; b) Nas outras localidades, a juizo do Governo, de accordo com o artigo antecedente" (Art. 102). Nas escolas reunidas, deveriam "os alumnos ser distribuidos em classes, adoptando-se nellas o regimen, methodo e processos de ensino dos grupos-escolares" (Art. 103). O relatório de João Lourenço Rodrigues inserido nos Anuários do Ensino do Estado de São Paulo de 1907-1908 sinaliza, porém, que mesmo antes de seu surgimento na legislação escolar, as escolas reunidas já existiam e que, apesar da denominação, elas tinham em comum apenas o fato de que funcionavam "numa mesma casa - nada mais. Cada uma conserva seu regimen, sua vida propria. Nem distribuição de alumnos pelo adiantamento, nem dosagem do ensino segundo os annos do curso, nem director para orientar o ensino das classes. Das classes, digo mal; das escolas, é que devia dizer" (p.35-36).

A princípio, pois, as escolas reunidas não podiam ser consideradas propriamente um tipo de escola primária, na medida em que consistiam numa simples junção de escolas isoladas num mesmo edifício escolar, embora seus professores não tivessem de pagar o aluguel do espaço. Aos poucos, não obstante, as escolas reunidas passaram a ser estruturadas de acordo com o modelo dos grupos escolares e algumas delas foram elevadas, posteriormente, a essa categoria de escola. No mesmo relatório, João Lourenço Rodrigues, referindo-se às 3 escolas reunidas criadas no ano anterior na Capital e no Rio das Pedras, explicava que, devido à sua organização, elas equivaliam a grupos escolares "em miniatura, tendo classes homogeneas e ensino graduado por annos. A escripturação é egualmente muito approximada da dos grupos e o periodo de ferias acha-se equiparado nos dois estabelecimentos" (p.36). Ao que parece, a idéia inicial era de que as escolas reunidas fossem mantidas em caráter provisório, tendo em vista que, nos Anuários do Ensino de 1909, é possível encontrar o seguinte comentário:

\footnotetext{
Entendemos que este typo de escola deve desapparecer, muito embora o governo forme grupos escolares de quatro classes no minimo pelas vantagens que advem dessa organização.

$\mathrm{Si}$, porém, ellas continuarem a fazer parte do nosso apparelho escolar, será necessario regulamental-as. Pedimos, nesse caso, venia para apresentar o seguinte projecto de regulamento: (...) Artigo $3^{\circ}$. - As escolas reunidas ficarão, em tudo, sujeitas ás leis, regulamentos, regimentos e programmas em vigor nos grupos escolares, salvo as restricções aqui estabelecidas (p.58).
}

O Decreto n. 2225, assim, oficializou a equivalência das escolas reunidas e dos grupos escolares. Apesar disso, os professores das primeiras recebiam vencimentos iguais aos daqueles que trabalhavam nas escolas isoladas, mesmo possuindo habilitação semelhante aos dos profissionais das escolas graduadas. Em 1917, entre os 94 integrantes do corpo docente 
das escolas reunidas - 49 mulheres e 45 homens - estavam 39 complementaristas, 26 normalistas, 25 normalistas primários, 2 intermédios e 2 adjuntos de concurso (Antunha, 1976).

Quanto à expansão das escolas reunidas, conforme os Anuários do Ensino de 19071908 existiam, até então, 4 delas na Capital, todas com diretor em comissão e situadas no Bom Retiro, no Belenzinho, na Avenida Paulista e na Lapa. Já no interior do Estado, eram 10 as escolas reunidas, das quais 5 tinham seus diretores assumindo também a regência de classe (Rio das Pedras, Pedreira, Monte Alto, Indaiatuba e Jardinópolis), 3 que funcionavam sem diretor (Santa Isabel, Parnaíba e Socorro) e 2 ainda em processo de organização (Cajurú e Matão). O quadro a seguir ${ }^{69}$ mostra que, em pouco tempo, 9 do total dessas 14 escolas reunidas transformaram-se legalmente em grupos escolares, em virtude do crescimento de classes e de matrículas (Antunha, 1976):

TABELA 11

\begin{tabular}{|c|c|c|c|}
\hline Denominação & Data de criação & Data de instalação & $\begin{array}{c}\text { Ano da transformação } \\
\text { em grupo escolar }\end{array}$ \\
\hline Bom Retiro & $17 / 04 / 1907$ & $01 / 05 / 1907$ & 1909 \\
\hline Belenzinho & - & $29 / 04 / / 1907$ & 1909 \\
\hline Rio das Pedras & $14 / 06 / 1907$ & - & 1911 \\
\hline Avenida Paulista & $29 / 07 / 1907$ & $12 / 08 / 1907$ & 1909 \\
\hline Lapa & $31 / 03 / 1908$ & $01 / 05 / 1908$ & 1909 \\
\hline Indaiatuba & $13 / 04 / 1908$ & $01 / 05 / 1908$ & 1911 \\
\hline Pedreira & $13 / 04 / 1908$ & $07 / 05 / 1908$ & 1910 \\
\hline Monte Alto & $13 / 04 / 1908$ & $09 / 05 / 1908$ & 1909 \\
\hline Jardinópolis & $13 / 04 / 1908$ & - & \\
\hline
\end{tabular}

De 1909 até 1920, a Capital não possuía nenhuma escola reunida, enquanto, no interior, elas passaram, no mesmo período, de 12 para 52. Ao longo da vigência da Reforma Sampaio Dória (1920-1925), ao contrário do que ocorreu com os grupos escolares, a rede de escolas reunidas aumentou substancialmente. À guisa de ilustração, se em 1921, apenas 6 delas estavam na Capital e 133 no interior, os índices subiram, respectivamente, para 28 e 329, em 1924. O número de classes acompanhou o crescimento das escolas reunidas: em 1910, existiam 32 classes, ao passo que, em 1924, elas já somavam 1.485. Antes da Reforma, o pequeno número de escolas reunidas refletia o modo como elas eram percebidas pelas

\footnotetext{
${ }^{69}$ Dados disponíveis em http://www.crmariocovas.sp.gov.br.
} 
autoridades escolares - "As escolas reunidas não constituem, no nosso apparelho educativo, um verdadeiro typo de escolas: - vivem uma vida transitoria, até que, apercebidas de elementos bastantes, possam fundir-se num Grupo Escolar" (Anuários do Ensino de 1917, p.262). A partir dos anos de 1920, contudo, diante das necessidades prementes de expansão do ensino primário - em 1919, das 492.278 crianças entre 7 e 12 anos de idade, mais da metade delas estava fora da escola (Antunha, 1976) - as qualidades das escolas reunidas passaram a ser exaltadas, especialmente por Guilherme Kuhlmann, sucessor de Dória na Diretoria Geral da Instrução Pública. Para ele, tais estabelecimentos eram "cômodos, de fácil administração e de baixo custo, devendo na medida do possível substituir os onerosos e complexos grupos escolares" (Antunha, 1976, p.197). Além das vantagens econômicas, passou-se a defender, especialmente nos Anuários do Ensino de 1923, que as escolas reunidas eram tão eficientes quanto os grupos escolares no que dizia respeito aos resultados obtidos e que, além disso, elas eram capazes de superar as deficiências das escolas isoladas, sendo, por isso, as mais adequadas escolas rurais. Não à toa, o Decreto n. 4101, de 14 de dezembro de 1926, dividiu as escolas reunidas em rurais e urbanas.

Sob o influxo dos ideais liberais de igualdade de oportunidades para todos, o governo paulista iniciou a organização do seu sistema primário de ensino. Nesse processo, ele teve de lidar não apenas com a ambição desmedida de modernização das elites, mas também com uma população escolar que não parava de aumentar e que, além disso, era heterogênea, isto é, composta por crianças de diferentes nacionalidades e origens sociais, bem como espalhada por todo o território paulista. Essas duas exigências, todavia, logo se mostraram irreconciliáveis. Assim, de 1887 a 1929, os planos de democratização do ensino não puderam ser concretizados. Face à exigüidade de recursos, a medida tomada pelo poder público foi priorizar, qualitativa e quantitativamente, as áreas urbanas. Isso significou, respectivamente: a criação das escolas-modelo e dos grupos escolares, dois tipos de escolas primárias cuja organização em tudo devia remeter ao que de havia de mais moderno nos modelos educativos em voga nos países tomados como referência de civilização, o que incluía os programas de ensino; a maior expansão numérica dos grupos escolares pelo Estado ${ }^{70}$, o que possivelmente

\footnotetext{
${ }^{70}$ Em outros estados brasileiros, a expansão do ensino primário, ao menos até 1930, não foi realizada por meio dos grupos escolares, mas sim das escolas isoladas e das escolas reunidas (Souza; Faria Filho, 2006). Na Paraíba, por exemplo, Lopes (2002) verificou que, em 1926, existiam 35 escolas reunidas, ao passo que, de 1916 - quando
} 
justifica o porquê dele ter sido confundido como sinônimo de escola primária (Souza, 2008). O ônus desse processo de inovação educacional foi o descaso com as escolas isoladas. Uma das poucas iniciativas realizadas a favor de sua melhoria foi a instituição das escolas-modelo isoladas, mas sobre as quais pouco se conhece. Por fim, o interesse pelas escolas reunidas uma modalidade de escola primária intermediária entre os grupos escolares e as escolas isoladas - só surgiu num momento crítico pelo qual passava o sistema público primário paulista. Em suma, longe de uniforme, a ação do Estado foi pautada pelo desigual grau de importância dada a cada uma das escolas primárias e, logo, aos grupos sociais que as freqüentavam. Em outros termos, a política educacional do período acabou por revelar-se altamente discriminatória, ao engendrar uma profunda hierarquia sócio-espacial. Conseqüentemente, o acesso das crianças aos saberes escolares variava conforme o meio em que as mesmas residiam, tal como se verá adiante.

o primeiro grupo escolar foi criado - até 1929, havia ao todo 14 grupos escolares, sendo 5 na Capital e 9 no interior. 


\section{Capítulo 2 - Nacionalizar e moralizar o povo: os programas de ensino prescritos pelo Estado}

O que eram os programas de ensino? De 1887 a 1929, o que os professores das escolas públicas primárias paulistas deviam ensinar estava registrado, por impresso, em documentos oficiais. Eles eram incorporados à legislação escolar e, portanto, procuravam impor uma ordem comum à escolarização (Souza, 2005). Tratavam-se dos chamados programas de ensino que, ao longo de todos esses anos, apresentaram as propostas culturais elaboradas pelo Estado para o público escolar. Assim, neles eram estabelecidos quais os elementos da herança cultural - do passado e do presente - eram tidos como os mais relevantes, ou seja, socialmente válidos para serem transmitidos às crianças (Forquin, 1992; Silva, 2007).

Augusto de Carvalho, ex-professor da Escola-Modelo "Caetano de Campos", define o programa de ensino como "um dos principaes elementos que o professôr tem a considerar para a organisação pedagogica da classe, ou da escola, estabelecendo, de antemão, o roteiro para a marcha progressiva dos espiritos: programma é o plano geral dos estudos de um estabelecimento de ensino" (O actual programma de ensino dos grupos e da escola-modelo I. In: Revista de Ensino, junho de 1909, n. 02, ano VIII, p.03-04). Mais do que o norte para o trabalho docente, não obstante, os programas de ensino eram o eixo em torno do qual girava todo o processo educativo. Enquanto tais, eles estavam no centro das relações intrínsecas entre outros três importantes componentes da cultura escolar, quais sejam, os métodos de ensino, o tempo e o espaço escolares (Faria Filho, 2002).

É possível considerar ainda que os programas de ensino possuíam uma importância simbólica, já que era através deles que o Estado tornava públicas e legítimas as suas escolhas no tocante aos objetivos da escola (Goodson, 2005). Com efeito, Augusto de Carvalho também afirma que, por meio dos programas de ensino, "sabemos logo qual o fim de uma casa de educação, qual a sua funç̧ão real" (O actual programma de ensino dos grupos e da escola-modelo III. In: Revista de Ensino, dezembro de 1909, n. 03, ano VIII, p.07). Desse modo, a opção em diferenciar os programas de ensino, tomada no decorrer do período estudado, revela que as finalidades reservadas pelo poder público a cada um dos tipos de escolas primárias não eram as mesmas. 
Por último, os programas de ensino, longe de atemporais e neutros, devem ser vistos como fruto de um processo de construção social conflituoso, no qual cada um dos diversos grupos sociais procurava impor seus interesses. Mas, afinal, quais foram os programas de ensino produzidos entre 1887 e 1929 para as escolas primárias paulistas? Eles sempre foram variados? Havia momentos específicos para eles serem publicados? Como eram organizados os saberes escolares nos programas? Como os profissionais da educação receberam determinados programas? Esses sujeitavam-se às demandas daqueles? O que se buscava a partir dos programas? Tais indagações vão permear o presente capítulo. Para tanto, ele dividese em três partes. Nas duas primeiras, são examinados os programas de ensino oficiais, atentando-se, principalmente, para as mudanças, ainda que pequenas, neles efetuadas. $\mathrm{Na}$ última, é realizada uma interpretação em torno das finalidades dos programas de ensino, baseada, sobretudo, nos textos dos periódicos educacionais e nos conteúdos das matérias incluídos nas prescrições.

\subsection{O que as escolas primárias paulistas deviam ensinar antes da diferenciação dos programas de ensino}

Quase sessenta anos separam a Lei de 15 de outubro de 1827 - a primeira e única lei geral sobre a instrução primária no Império (Faria Filho, 2000, p.149) - da Lei n. 81, de 06 de abril de 1887, que reforma a instrução pública paulista ${ }^{71}$ (Moacyr, 1939, p.417). A primeira disposição legal determinava que, nas escolas de primeiras letras, os professores deviam ensinar

a ler, escrever, as quatro operações de aritmética, prática de quebrados, decimais e proporções, as noções mais gerais de geometria prática, a gramática da língua nacional, os princípios de moral cristã e de doutrina da religião católica e apostólica romana, proporcionadas à compreensão dos meninos, preferindo para as leituras a Constituição do Império e a História do Brasil (Art. $6^{\circ}$.).

As professoras, por sua vez, "além do declarado no Art. $6^{\circ}$., com exclusão das noções de geometria, e limitando a instrução da aritmética só às suas quatro operações, ensinarão também as prendas que servem à economia doméstica" (Art. 12 ${ }^{\circ}$.

Já a Lei n. 81 dividiu a instrução primária em três graus "apropriados à idade e ao desenvolvimento intelectual dos alunos, compreendendo as seguintes matérias" (apud

\footnotetext{
${ }^{71}$ Essa reafirma, com pequenas modificações, a Lei de 02 de maio de 1885 (Gallego, 2008, p.206).
} 
Moacyr, 1939, p.426) para o $1^{\circ}$. grau, destinado a crianças de ambos os sexos entre 7 e 14 anos (Gallego, 2008, p.186) ${ }^{72}$ :

educação cívica; educação religiosa (facultativa para os filhos dos acatólicos); lição de coisas com observação espontânea; leitura, ensino proporcionado ao desenvolvimento das faculdades do aluno, a ponto de ler corretamente, prestando o professor atenção à prosódia; exercícios de análise sobre pequenos trechos lidos de modo a poder o aluno compreendê-los e ficar, sem decorar regras gramaticais, conhecendo a construção de frases e sentenças; escrita graduada com aplicação das regras de ortografia; aritmética elementar, incluindo as quatro operações fundamentais, frações ordinárias e decimais e regra de três simples, com exercícios práticos e graduados de uso comum; ensino prático do sistema legal de pesos e medidas; desenho linear de mão livre e caligrafia; exercício de redação de cartas, contas e faturas comerciais; noções de geografia geral e física concernentes aos fenômenos de evaporação, formação de nuvens, das chuvas, do vento, das serras e das montanhas, de sua influência na formação dos rios etc., guiando os alunos ao conhecimento do mapa da Província; ginástica; canto coral. (...) Nas escolas do sexo feminino haverá mais: nas do $1^{\circ}$. grau: costura simples (grifos meus; apud Moacyr, 1939, p.426-428).

Embora de 1827 a 1887 outros programas para o ensino primário tenham sido publicados $^{73}$, eles pouco modificaram aquele incluído na Lei de 15 de outubro de 1827, continuando a privilegiar os saberes elementares (a leitura, a escrita e o cálculo) e a doutrina religiosa (Reis Filho, 1995, p.132; Gallego, 2008, p.204-205). O programa de ensino que fazia parte da Lei n. 81, nesse sentido, representou uma inovação significativa no ensino primário paulista, ao não diferenciar os saberes segundo o sexo das crianças (com exceção da costura simples, só para as meninas), ao ampliar o antes exíguo rol de matérias e ao acrescentar detalhes como conteúdos e orientações ao professor. Sua criação evidencia que a constatação de que era essencial repensar as finalidades da educação popular apareceu ainda no Império, subvertendo a idéia, comum na historiografia brasileira, de que a educação primária no século XIX ficou "confinada entre a desastrada política pombalina e o florescimento da educação na era republicana" (Faria Filho, 2000, p.135). Os Pareceres sobre a Reforma do ensino primário e várias instituições complementares da instrução pública, escritos por Rui Barbosa em 1882, também são exemplos de que a questão do que ensinar ao povo já era debatida à época. No documento, ele sugeria a elaboração de um programa de ensino fundamentado no princípio da educação integral e que fosse enciclopédico, no qual as novas

\footnotetext{
${ }^{72}$ Como adiantado na Introdução, o primeiro programa de ensino produzido para as escolas-modelo, em 1890 , era muito próximo a esse programa do $1^{\circ}$. grau. Assim, nessa dissertação optou-se pela análise apenas dele, e não dos programas do $2^{\circ}$. e do $3^{\circ}$. graus, tarefa já realizada por Gallego (2008).

${ }^{73}$ Conforme a descentralização do ensino definida pelo Ato Adicional de 1834, cumpria às Províncias desenvolver o ensino primário. Em São Paulo, a Lei n. 34, de 16 de março de 1846 e o Regulamento de 17 de abril de 1868 introduziram, respectivamente, o ensino da gramática da língua nacional e o da gramática portuguesa (Gallego, 2008).
} 
matérias ${ }^{74}$ permitissem que a escola primária se ajustasse às necessidades da vida moderna, tal como vinha ocorrendo nos países tidos como mais adiantados, isto é, aqueles da Europa e os Estados Unidos (Souza, 2008). Assim, ao ver de intelectuais, educadores e políticos, as escolas de primeiras letras, ao limitarem-se ao ensino dos saberes elementares e da doutrina cristã, não podiam acompanhar, com êxito, os novos rumos do país.

Outro fator que influenciou o enriquecimento do programa de ensino de 1827 foi a redefinição do lugar ocupado pela escola na sociedade. Ao longo do século XIX, ela teve de disputar com tradicionais instituições, tais como a família, a Igreja, o trabalho e a vizinhança, a função de socializar e de transmitir saberes (Varela\&Alvarez-Uria, 1992; Faria Filho, 2002). Ao tornar-se a principal agência de formação das novas gerações, a escola teve de ser reformulada internamente. Aos poucos, os defensores da escola passaram a propalar cada vez mais a necessidade de se dotar a escola de elementos que lhe conformassem uma identidade própria, ou seja, que marcassem com mais nitidez as diferenças entre os sujeitos escolarizados e aqueles cujo aprendizado se realizava através de outros meios (Gallego, 2008). Isso explica por que os programas de ensino foram ganhando densidade à medida que aumentava a complexidade das relações entre eles, os métodos de ensino, o tempo e o espaço escolares. Em outros termos, na ocasião da Lei Geral de 1827, o modo de funcionamento das escolas de primeiras letras - método de ensino individual e conseqüente reduzido tempo de ensino efetivo, além da ausência de espaços próprios - impedia a aplicação de programas de ensino mais longos e evidenciava seu baixo grau de institucionalização (Faria Filho, 2002).

O contraste entre o programa de ensino das primeiras décadas do século XIX e aquele do final desse período também pode ser interpretado como resultado da crescente intervenção do Estado no campo da educação (Faria Filho, 2000, p.137). Para as elites políticas, o recurso aos preceitos legais era imprescindível para a tão almejada modernização do país. A partir de 1870, ano que inaugurou a fase denominada por Barros de "ilustração brasileira" (1959), o país foi palco da chegada de novas idéias, em especial do liberalismo, do positivismo e do evolucionismo social. De alguma forma, esse movimento - que se prolongou até a Primeira Guerra Mundial - herdou as características do Iluminismo europeu do século XIX, a saber, a crença no poder das idéias em transformar radicalmente o país e a concepção da ciência e das escolas como "fontes de luz", capazes de elevar o país ao "nível do século", isto é, de igualálo às nações mais desenvolvidas. A superação do "atraso cultural” do Brasil dependia, por

\footnotetext{
${ }^{74}$ São elas: educação física, música e canto, desenho, língua materna, rudimentos das ciências físicas e naturais, matemática e taquimetria, geografia geral e cosmografia, história, rudimentos da economia política e cultura moral e cívica (Souza, 2000b, p.15).
} 
isso, da escola, considerada, pelos homens que renovaram a mentalidade brasileira, como a instituição, por excelência, que organiza e desenvolve as idéias (Barros, 1959). Essas, por sua vez, deveriam ser expressas na legislação. Conseqüentemente, era através dela que se procurava fundar uma nova realidade brasileira. A lei tinha, desse modo, um caráter antecipador, já que fixava um ideal a ser concretizado. Com isso, a “"consciência jurídica' liberal, uma das principais molas da ilustração brasileira, não era uma forma de alienação, mas um princípio civilizador” (Barros, 1959, p.25). A legislação, em outros termos, pode ser definida como uma prática de ordenação das relações sociais, uma vez que, no entender do Estado, era preciso criar meios de atuação sobre o povo brasileiro para que ele não se desviasse do caminho que lhe foi traçado (Faria Filho, 1998; 2000). Os programas de ensino, nesse caso, representavam uma forma de controlar o que se ensinava e, logo, o que se aprendia.

A propósito, o processo de estatização da escola primária trouxe profundas conseqüências para os programas de ensino. Fundada primeiro na Europa Ocidental e posteriormente disseminada nos demais países, a escola estatal de massas é indissociável do surgimento dos Estados-Nações. Isso porque ela consistia num "esforço para construir um Estado nacional; o poder do Estado-nação, pensava-se, seria unificado através da participação dos cidadãos do Estado nos projetos nacionais" (Goodson, 1997, p.81). A escola de massas foi, em suma, o principal mecanismo utilizado para se forjar ligações simbólicas entre os indivíduos e os Estados-Nações. Para a formação da identidade nacional, pois, a escola de massas era crucial e, logo, tornava-se indispensável a renovação dos programas de ensino. Nesse caso, a despeito de algumas especificidades, a difusão mundial da escola de massas, iniciada em meados do século XIX, foi marcada por similiaridades (Meyer; Ramirez; Soysal, 1992). Com efeito, nos países que organizaram seus sistemas públicos de ensino, quer "ao nível de massas, quer de elites, os currículos educativos apresentam evidentes semelhanças e mudanças convergentes" (Meyer, 2000, p.18). O que propiciou esse certo isomorfismo foi a circulação de idéias e de modelos educativos por veículos como as Exposições Universais, os Congressos de Instrução e publicações como livros e periódicos diversos (Souza, 2000b, p.11). Por todo o mundo, a substituição da Igreja pelo Estado no que tange à função educativa provocou a emergência de uma nova cultura escolar, agora fundamentada na idéia de Pátria e na secularização do ensino, estreitamente vinculada à secularização da moral (Petitat, 1994).

Diante desse quadro, é possível delinear algumas das motivações que levaram à produção do programa de ensino apresentado pela Lei n. 81, de 06 de abril de 1887. A 
incorporação das matérias Educação cívica e Noções de geografia geral e fisica davam o tom nacionalista necessário, enquanto a Lição de $\operatorname{coisas}^{75}$, a Ginástica e o Canto coral, indicam o intuito de se modernizar a cultura oferecida ao povo. Ademais, a Educação religiosa, sendo facultativa para as crianças cujos pais não eram católicos, mostra que já estava em curso uma tendência para a laicização do ensino, que culminou pouco tempo depois. Por fim, a prescrição do Ensino prático do sistema legal de pesos e medidas, do Desenho linear de mão livre e caligrafia e do Exercício de redação de cartas, contas e faturas comerciais deixa entrever a intenção de se transmitir às crianças saberes utilitários, que possibilitassem o desempenho de atividades urbanas, como aquelas ligadas à indústria e ao comércio, em crescente expansão naquele momento, como visto no capítulo anterior.

Importa destacar ainda que o programa descrevia, além das matérias, alguns conteúdos, tais como os de Aritmética elementar ("as quatro operações fundamentais, frações ordinárias e decimais e regra de três simples, com exercícios práticos e graduados de uso comum") e de Geografia geral e Geografia física ("fenômenos de evaporação, formação de nuvens, das chuvas, do vento, das serras e das montanhas, de sua influência na formação dos rios, etc."). O programa trazia ainda orientações ao professor sobre o ensino da Leitura ("prestando o professor atenção à prosódia"), bem como expectativas quanto ao nível de conhecimento a ser alcançado pelo aluno no que tange a essa matéria ("a ponto de ler corretamente") e aos Exercícios de análise ("de modo a poder o aluno compreendê-los e ficar, sem decorar regras gramaticais, conhecendo a construção de frases e sentenças").

A partir da proclamação da República, como parte indispensável da construção do sistema público primário paulista, a legislação escolar vai incidir sobre todos os aspectos da organização escolar: o método de ensino, o tempo (determinação da idade escolar obrigatória, do calendário e da jornada escolar e da duração do curso primário), os programas de ensino, entre outros, passaram a ser objeto de inúmeras prescrições, criadas para garantir a uniformidade de um projeto voltado à formação do cidadão republicano (Souza, 1999, p.130). Seguindo o percurso histórico dos programas do ensino primário aqui empreendido, o primeiro programa dessa nova fase, assim como o anterior, também foi publicado no âmbito de uma reforma. Dessa vez, ele foi dirigido ao $1^{\circ}$. grau das escolas-modelo anexas à Escola

\footnotetext{
${ }^{75}$ Aqui, ao que parece, a lição de coisas, apesar de ser a denominação pela qual ficou vulgarizado o método
} intuitivo, designava uma matéria, e não uma orientação sobre o ensino (Souza, 1997). 
Normal (para crianças entre 7 e 10 anos de idade) e inserido no Decreto n. 27, de 12 de março de 1890, que reformulou a Escola Normal e converteu em escolas-modelo as escolas anexas a ela. A análise do programa mostra que ele possui muitos pontos em comum ao de 1887 . Segundo Reis Filho (1995, p.134), deve-se isso ao fato de que Rangel Pestana, mentor da Reforma que ficou conhecida como "Caetano de Campos", havia participado da elaboração da Lei n. 81, na Assembléia Provincial. Havia, contudo, algumas diferenças entre os dois programas: a supressão do ensino religioso e a inclusão da matéria Trabalhos manuais e de seus respectivos conteúdos ("construções, trabalhos a cola, papel dobrado, trabalhos em papelão, em cordas, em vime"), além daqueles referentes à Ginástica ("marchas escolares e exercicios militares").

A laicidade do ensino não foi bem aceita por alguns professores. À guisa de ilustração, em relatório de 01 de junho de 1892, Maria Marcolina Pinheiro, da Escola pública do sexo feminino do bairro do Maranhão, argumentou que a educação religiosa foi "com grande prejuízo (...) supprimida no programma do ensino primario”. Gertrudes Miquelina Alves Pinto, por sua vez, em 01 de junho de $1890^{76}$, assim manifestou-se:

Quanto ao ensino religioso foi com grande pesar que soube que estava expressamente prohibido nas escolas publicas.

Emquanto eu julgava que as professoras eram livres, isto é, que, querendo, podiam continuar a ensinar a doutrina christã, eu assim o fazia por isso que as meninas matriculadas em minha escola são todas de familias catholicas, tanto que, a pedido d'ellas, começára a preparar algumas para fazerem a $1^{\mathrm{a}}$. Communhão. Foi pois de máu grado meu e de minhas alumnas que deixamos o ensino religioso.

Cumpre lembrar que a retirada do ensino religioso do programa das escolas públicas foi determinada pelo Decreto n. 34, de 12 de março de 1890, nos seguintes termos:

\begin{abstract}
a educação religiosa não póde continuar a fazer parte do programma de ensino nas escolas publicas, por ser isso contrario ao decreto de 7 de janeiro do corrente anno, que, separando a egreja do Estado, estabeleceu plena liberdade de crenças e de cultos, e prohibiu crear differenças entre os habitantes do paiz, ou nos serviços sustentados á custa do orçamento, por motivos de crenças ou opiniões philosophicas ou religiosas.
\end{abstract}

Pondo fim a uma religião oficial, a Constituição da República de 1891 buscou solucionar as tensões entre a Igreja e o Estado, agravadas na década de 1870, e ainda facilitar a integração dos estrangeiros, que cada vez mais chegavam ao país e, muitas vezes, não eram católicos (Fausto, 2007). Somava-se a isso a adoção dos princípios liberais pelos republicanos, o que tornou a mentalidade católico-conservadora "a adversária natural da 'ilustração

\footnotetext{
${ }^{76}$ Ambos os relatórios foram localizados na lata de Ordem 4931 (Arquivo Público do Estado de São Paulo).
} 
brasileira': não que esta se defina apenas pelo seu anti-catolicismo, pelo anti-clericalismo: ela sonha, entretanto, em transformar o país e, nessa transformação, não haveria lugar mais para os privilégios religiosos" (Barros, 1959, p.65).

Em 1892, no contexto da Reforma Geral da Instrução Pública (Lei n. 88, de 08 de setembro), foram criados dois novos programas de ensino: um para as escolas preliminares e outro para as escolas provisórias, auxiliares das primeiras. Ambas eram responsáveis em ministrar um dos cursos nos quais se dividia o ensino primário: o preliminar, de 4 anos, obrigatório para crianças entre 7 e 12 anos de idade. O texto da Lei foi redigido por Artur Guimarães, Diretor da Instrução Pública, Tomás Galhardo, professor público e Sr. Alvarenga, diretor da Secretaria Geral da Instrução Pública (Souza, 1997). Em 30 de dezembro do mesmo ano, o Decreto n. 144-B regulamentou a Lei, reafirmando esses dois programas de ensino. Além disso, a ela adicionou que, nas escolas intermédias, também auxiliares das escolas preliminares e regidas por professores habilitados de acordo com os Regulamentos de 18 de abril de 1869 e de 22 de agosto de 1887 - o programa de ensino devia ser o mesmo daquelas, "sem que, porém, os respectivos professores fiquem obrigados ao ensino das matérias acrescidas, de que não tenham exames" (Artigo 57). Conforme ressaltado no Capítulo 1, o critério que diferenciava essas três escolas era a formação dos professores que nelas lecionavam, como bem resume o inspetor escolar Francisco Pedro do Canto, em relatório datado de 1900: "É o professor que classifica a escola" (Ordem 7025). Dessa forma, ao que tudo indica, o Estado já antevia a impossibilidade daqueles não diplomados pela Escola Normal executarem um programa extenso, como era o caso daquele das escolas preliminares. Por isso, nas escolas provisórias, onde trabalhariam os professores interinos, seriam ensinados apenas "Leitura, princípios de cálculo, escrita, geografia geral do Brasil, princípios básicos das Constituições da República e do Estado" (Artigo 70 da Lei n. 88).

Já o programa de ensino das escolas preliminares que, conforme o Art. 412 do Decreto n. 144-B, também devia ser seguido pelas escolas-modelo anexas à Escola Normal, estava assim definido:

moral prática e educação cívica; leitura e princípios de gramática, escrita e caligrafia; noções de geografia geral e cosmografia; geografia do Brasil, especialmente do Estado de São Paulo; história do Brasil e leitura sôbre a vida dos grandes homens da história; cálculos aritméticos sobre os números inteiros e frações; sistema métrico decimal; noções de geometria especialmente nas suas aplicações à medição de 
superfícies e volumes; noções de ciências físicas, químicas e naturais, nas suas mais simples aplicações, especialmente à higiene; desenho a mão livre; canto e leitura de música; exercícios ginásticos, manuais e militares, apropriados à idade e ao sexo (Artigo $6^{\circ}$. da Lei n. 88).

Para as escolas-modelo, esse novo programa de ensino implicou na introdução da Moral prática, da História do Brasil e leitura sobre a vida dos grandes homens da história, das Noções de ciências fisicas, químicas e naturais, da Leitura de música e da Cosmografia. Por outro lado, foram excluídas as Lições de coisas, os Exercícios de análise, os Exercícios de redação e as Noções de geografia fisica.

Outra novidade trazida pelo Decreto n. 144-B foi a de que o curso das escolas preliminares devia ser dividido em séries, "abrangendo cada uma delas um semestre do ano letivo" (Artigo 56). Apesar disso, não era definido o que se devia ensinar em cada uma dessas séries. Essa determinação permaneceu no Decreto n. 218, de 27 de novembro de 1893, que aprovou o Regulamento da Instrução Pública para a execução da Lei n. 88, de 08 de setembro de 1892 e da Lei n. 169, de 07 de agosto de 1893. Também nesse documento, os programas de ensino das escolas preliminares, o das provisórias e o das intermédias voltaram a ser publicados. Não há, contudo, nenhuma modificação neles, exceto o fato de que a matéria das escolas preliminares Contar e calcular sobre números inteiros e frações passou a ser designada como Cálculo aritmético sobre números inteiros e frações.

No que diz respeito às escolas-modelo anexas à Escola Normal, o Artigo 413 do Decreto n. 218 tornou a enfatizar que "o ensino comprehenderá todas as matérias determinadas para o curso preliminar ou complementar, conforme a natureza da escola, observando-se na distribuição delle, o programma detalhado que houver sido préviamente approvado". Em todos os tipos de escolas primárias foram mantidos, assim, os programas de ensino em vigor.

O Decreto n. 248, de 26 de julho de 1894, aprovou o Regimento Interno das escolas públicas do Estado de São Paulo e foi elaborado por Oscar Thompson e Benedito Maria Tolosa, ambos diretores adjuntos da Escola-Modelo do Carmo, e por Antônio Rodrigues Alves Pereira, inspetor escolar (Souza, 1997; Gonçalves\&Warde, 2002). Se até o momento os programas de ensino foram incorporados às leis e decretos por meio de "Artigos", o documento inovou ao trazer, em anexos, um programa de ensino, nesse caso, para as escolas 
preliminares. Esse, por sua vez, apresentou um novo modo de organização dos saberes escolares, baseado no ensino concêntrico ${ }^{77}$ : a descrição dos conteúdos ${ }^{78}$ das matérias de cada uma das oito séries do curso (cada um dos 4 anos era subdividido em duas séries), o que não havia no Decreto n. 144-B, de 30 de novembro de 1892 e no Decreto n. 218, de 27 de novembro de 1893, como assinalado. Com isso, as matérias eram repetidas a cada série, mas deviam ser aprofundadas de uma para outra, em obediência ao desenvolvimento intelectual, moral e psíquico da criança (Souza, 1997). A propósito, as matérias não sofreram mudanças, apesar do termo "dedução" do título Leitura e dedução de princípios de gramática ter sido acrescentado e das Noções de ciências físicas, químicas e naturais, que passaram a ser denominadas de Noções de física, química e história natural. Além disso, no $1^{\circ}$. ano não estava previsto o ensino de História do Brasil, que começava apenas na $2^{\mathrm{a}}$. série do $2^{\circ}$. ano. Já o ensino de Geografia tinha início na $2^{\mathrm{a}}$. série do $1^{\mathrm{o}}$. ano.

\footnotetext{
${ }^{77} \mathrm{Na}$ visão de Gallego (2008, p.206), o ensino concêntrico já estava esboçado na Lei de 02 de maio de 1885 , reafirmada pela Lei n. 81, de 06 de abril de 1887: a autora notou o aumento progressivo do teor das matérias ao longo dos três graus nos quais era dividido o ensino primário. Já para Souza (1997), foi a Lei n. 88, de 08 de setembro de 1892, que marcou essa inovação. Por sua vez, o inspetor escolar Theodoro de Moraes, em relatório presente nos Anuários do Ensino de 1910-1911, aponta que a "lei aurea de nossa organização pedagogica actual, a de 7 de Agosto de 1893, traçou claramente a divisão do ensino primario em dous cursos: preliminar e complementar. Esta distribuição de ensino, longe de ser fragmentaria, estabelecia em toda a extensão do programma de ensino primario uma marcha racionalmente concentrica, gradual e intensiva" (p.14).

${ }_{78}$ Alguns desses conteúdos e daqueles dos demais programas de ensino a seguir analisados serão comentados posteriormente.
} 


\section{$\therefore \times N(1)$}

1.1:I:Y.11:A S:1:11:

Gumurtien. - Exereicios nilitares.

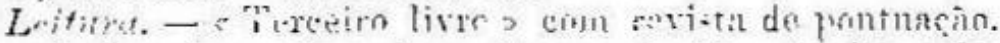
Lso partienlar tas minceulas. J)ur a sisnifieaçe das pala-

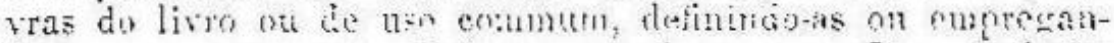

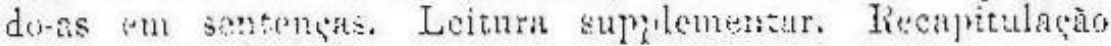
sobre sons e lettras.

E.reverios ormes - Sentenças : fiumar pequenas sen-

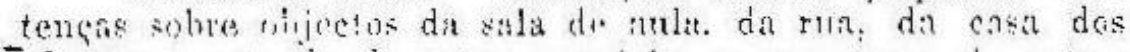
-alumnos, extesdendo iestes exercicios a acsumytos de ontras aulas.

Attenção à bua enuuciaçà dos pensanentos.

Exciptc. - Thictar pequeucs treckos expressives para as ereauças. Counosięño: escrever sentenęas con palavras dadas e bem eonlecides. cedencia.

Fequenas bistorias lidas on classe com alguna ante-

Calligrapitia. - Segundo e teresiro cadernos.

drifhmetice. - Generalidades. Simeraçăo falnda e escripta. Prova da addiçào e da subtracçào. Taboas de multiplicar e dividir até a casa do 15. Fracçóes ordinatias, proprias e improprias. Eștudo eompleto da multiplicação. Problemas e questioes praticns.

Systema metrico. - Vetro, litro, gramma, multiplos e suburaltiplos.

Geographia. - Orieułaça, poutos cardeaes e collateraes. Ihosa dos ventos. Heios de determinal-os e recouhccer. Mappa

FIGURA 1 - Programa de ensino das escolas preliminares (1894)

Já o programa de ensino das escolas intermédias e o das escolas provisórias permaneceram os mesmos, embora nessas, a matéria antes intitulada Geografia Geral do Brasil tenha sido anunciada como Geografia Geral e do Brasil.

Em relação aos grupos escolares, recém criados, como não existia até então nenhum Regimento dedicado especificamente a eles, foram obrigados a seguir o programa de ensino das escolas preliminares (Souza, 1997, p.43). Curiosamente, nas escolas-modelo anexas à Escola Normal devia continuar o ensino de "todas as materias mencionadas no art. $6^{\circ}$. da Lei $n^{\text {o }} .88$ de 8 de Setembro de 1892", conforme o Decreto n. 397, de 09 de outubro de 1896, que aprovou o Regulamento da Escola Normal da Capital e das Escolas-Modelo anexas. Para as demais escolas-modelo, essa mesma orientação legal era válida (Decreto n. 1216, de 27 de abril de 1904, que aprovou e mandou observar o Regimento Interno dos grupos escolares e 
das escolas-modelo). Convém destacar que, à época, a duração do curso das escolas-modelo e dos grupos escolares já não era mais de 4, mas de 5 anos. Essa alteração temporal, efetuada a partir de 1895, entretanto, não foi acompanhada pela publicação de um novo programa de ensino para esses dois tipos de escolas primárias, o que só viria a ocorrer em 1904.

O Decreto n. 1217, de 29 de abril de 1904, entrou em vigor especialmente para aprovar e mandar observar o programa de ensino das escolas-modelo e dos grupos escolares. Ele inaugurou, assim, uma nova forma de publicação dos programas, não mais parte do texto de leis e decretos, como ocorria até o Regimento Interno de 1894, tampouco como anexos dos mesmos, como foi o caso desse. As matérias consistiam na "Leitura; Linguagem; Calligraphia; Arithmetica; Geometria; Geographia; Historia do Brazil; Sciencias physicas e naturaes - Hygiene; Instrucção civica e moral; Gymnastica e exercicios militares; Musica; Desenho; Trabalho manual". Mantinha-se, pois, praticamente o mesmo conjunto de matérias até então ensinado, mas em todas elas, são descritos, para cada um dos 5 anos do curso, os itens "processos", "programa" e "lições auxiliares", o que configurava um nível de detalhamento até então inédito. O primeiro item traz algumas observações, relativas, por exemplo, às finalidades das matérias, aos métodos de ensino e aos horários em que elas deviam ser ministradas. Já o item "programa" apresenta os conteúdos, que são complementados no item "lições auxiliares". 
Programma d: ensiuo dos grupos eseholates e das escholus-modelo

\section{LEITURA}

\subsection{ANSO}

Frocersos. Q Qter seja emprevato o processo de sylabsçăo, quer

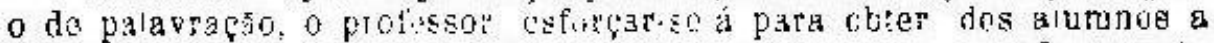

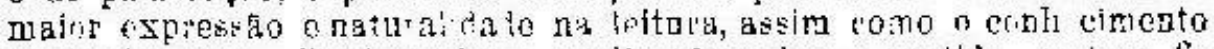
do trecho lifo. Fará tambey explieaçân sobre o sentido real na garado das paiarr a enegrtrahas no livro de leitara. Nenhana palava poderá sor enijada d́ creança sem que ela tenha idéa clara da

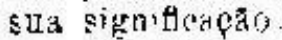

Programma...Fa'arras e o gue el...ss apreentam. Sons a letras. Sentenęys formadas de palavtes fumbiares. Conrexa de prononcla. Livro de leitara iproprisdo á edad $\mathrm{e}$ ao cestnvolfimento do einmno. Signaes de pontüção.

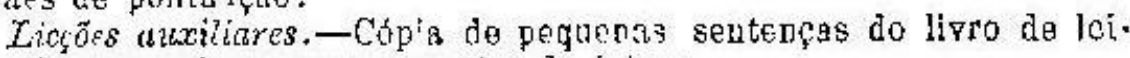
tura, f rmar palavrus ecm extoüus lo lotras.

$$
2 .{ }^{\circ} \text { A } N \text { : }
$$

Precseas.-Observar as tegras te prontuncia e a influxăo necessa-

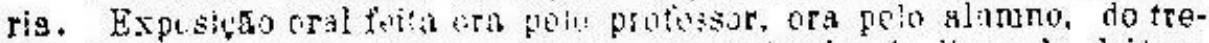
cho liśn. Convem. algumas vezes. g qu o tefcho do livro de leitura seja lido prio prcfessor, e otvidi e roproduzido pela classa.

Frogramma. - Livro de leitura apropriado á ećado $B$ an desezvolvinunto dos slamnos. Leitura claris de pequenos trechus, esforeandose a prifuser por ubter dus aluminos a maior exijesedo o naturalidare, assim como o ennliecimento do tresho lido. Sígages de pontar. cáo. Dlyiedo de syllabas. Syronymos.

Licçöes auxiliarek. - Leitara $\mathrm{f} \cdot \mathrm{m}$ clasze de peqnenos trechos de revistas e jornaes apiopriados á classe. Leituras anxiliares sobre as diversas diecplines.

FIGURA 2 - Programa de ensino das escolas-modelo e dos grupos escolares (1904)

O Artigo 31 do Decreto n. 1239, de 30 de setembro de 1904, definiu que os "programmas adoptados serão uniformemente observados na eschola-modelo, nos grupos escholares e nas escholas isoladas", o que significava que o novo programa também devia ser seguido pelas últimas. Não havia, contudo, nenhuma menção de como ficaria a duração do curso delas. O programa de ensino aprovado pelo Decreto n. 1217, de 29 de abril de 1904, marcou o fim da equiparação entre os programas de ensino das diversas escolas primárias. Por isso, cabe aqui uma síntese da história dos programas do ensino primário no período que vai de 1887 a 1904: 
TABELA 12

\begin{tabular}{|c|c|c|}
\hline $\begin{array}{c}\text { Documento no qual o } \\
\text { programa de ensino foi } \\
\text { inserido }\end{array}$ & $\begin{array}{c}\text { Tipo de } \\
\text { escola primária ao qual o } \\
\text { programa se destinava }\end{array}$ & $\begin{array}{l}\text { Duração } \\
\text { do curso }\end{array}$ \\
\hline $\begin{array}{c}\text { Lei n. } 81 \text {, de } 06 \text { de abril } \\
\text { de } 1887\end{array}$ & $1^{\circ}$. grau do ensino primário & Não era determinada ${ }^{79}$ \\
\hline $\begin{array}{c}\text { Decreto n. } 27, \text { de } 12 \text { de } \\
\text { março de } 1890\end{array}$ & $\begin{array}{c}\text { Escolas-modelo anexas à } \\
\text { Escola Normal }\end{array}$ & 4 anos \\
\hline $\begin{array}{l}\text { Lei n. } 88 \text {, de } 08 \text { de } \\
\text { setembro de } 1892\end{array}$ & $\begin{array}{l}\text { Mesmo programa: escolas- } \\
\text { modelo anexas à Escola } \\
\text { Normal e escolas } \\
\text { preliminares } \\
\text { Outro programa: escolas } \\
\text { provisórias }\end{array}$ & 4 anos \\
\hline $\begin{array}{c}\text { Decreto n. 144-B, de } 30 \\
\text { de novembro de } 1892\end{array}$ & $\begin{array}{l}\text { Mesmo programa: Escolas- } \\
\text { modelo anexas à Escola } \\
\text { Normal e escolas } \\
\text { preliminares } \\
\text { Programas específicos para } \\
\text { cada uma: escolas } \\
\text { provisórias e intermédias }\end{array}$ & 4 anos \\
\hline $\begin{array}{l}\text { Decreto n. } 218 \text {, de } 27 \text { de } \\
\text { novembro de } 1893\end{array}$ & $\begin{array}{c}\text { Escolas-modelo anexas à } \\
\text { Escola Normal e escolas } \\
\text { preliminares } \\
\text { Programas específicos para } \\
\text { cada uma: escolas } \\
\text { provisórias e intermédias }\end{array}$ & 4 anos \\
\hline $\begin{array}{c}\text { Decreto n. } 248, \text { de } 26 \text { de } \\
\text { julho de } 1894\end{array}$ & $\begin{array}{l}\text { Mesmo programa: escolas } \\
\text { preliminares e grupos } \\
\text { escolares } \\
\text { Programas específicos para } \\
\text { cada uma: escolas } \\
\text { provisórias e intermédias }\end{array}$ & 4 anos \\
\hline $\begin{array}{l}\text { Decreto n. } 397 \text {, de } 09 \text { de } \\
\text { outubro de } 1896\end{array}$ & $\begin{array}{c}\text { Escolas-modelo anexas à } \\
\text { Escola Normal devem } \\
\text { seguir a Lei n. } 88\end{array}$ & 5 anos \\
\hline $\begin{array}{l}\text { Decreto n. } 1216 \text {, de } 27 \\
\text { de abril de } 1904\end{array}$ & $\begin{array}{c}\text { Estende o Decreto n. } 397 \\
\text { para as demais escolas- } \\
\text { modelo }\end{array}$ & 5 anos \\
\hline $\begin{array}{c}\text { Decreto n. } 1217 \text {, de } 29 \\
\text { de abril de } 1904\end{array}$ & $\begin{array}{c}\text { Escolas-modelo e grupos } \\
\text { escolares }\end{array}$ & 5 anos \\
\hline $\begin{array}{c}\text { Decreto n. } 1239 \text {, de } 30 \\
\text { de setembro de } 1904\end{array}$ & $\begin{array}{c}\text { Estende o Decreto n. } 1217 \\
\text { para as escolas isoladas }\end{array}$ & Não há indicação \\
\hline
\end{tabular}

${ }^{79}$ Gallego (2008, p.206). 


\subsection{O início da diferenciação dos programas de ensino}

O Decreto n. 1281, de 24 de abril de 1905, assim como o anterior, aprovou e mandou observar o programa de ensino das escolas-modelo e dos grupos escolares. À época, a Lei $n$. 930, de 13 de agosto de 1904, havia diminuído a duração do curso de 5 para 4 anos. Apesar disso, as matérias foram mantidas: "Leitura; Linguagem; Calligraphia; Arithmetica; Geographia; Historia do Brazil; Sciencias physicas e naturaes - Hygiene; Instrucção civica e moral; Gymnastica e exercicios militares; Musica; Desenho; Geometria; Trabalho manual”. No entanto, ao contrário do que ocorria no antigo programa, o ensino da História do Brasil não estava previsto para o $1^{\circ}$. ano do curso. O novo programa de ensino também é menos minucioso que o de 1904: os itens "programa" e "lições auxiliares" desapareceram, embora seja possível notar que foram condensados nos conteúdos que, pois, sofreram redução.

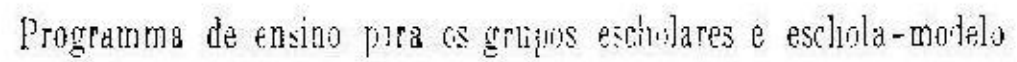
MRTMETLO ANAO

Leitura

Palavras-o que ellas rojrosentam e significam. Sentenças formadas com palavias estudadas.

Formar, com cartóes de lettras, as palarras e sentenças lidas

Linguagem

Oral-Deserinçăo de objectos communs.

Dešripção de objectons presentes e ausentes.

Narraçâo de factos instructivos e moraes, com reproducção socratica o completa da mesma. Recitaçào de maximas e poesias apropriadas á classo.

Escripta-Copiar palayras e pęquenas sentenças do quadronegro on do livro de leitara. Dictado do palavras e seutenças faccis. Escrever sentenças com palavias dadas. Uso das lettras maiu sculas.

\section{Calligraphia}

Copiar lettras, palavras, al garismos o pequenas sentenças do livro de leitura ou escriptas no quadro-negro.

FIGURA 3 - Programa de ensino das escolas-modelo e dos grupos escolares (1905) 
As modificações fizeram com que esse programa de ensino fosse alvo de fortes críticas por parte da Revista de Ensino. O já referido Augusto de Carvalho assinou três textos, todos

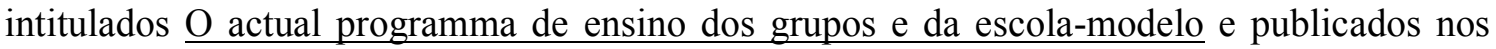
números de junho, setembro e dezembro de 1909 do periódico. A leitura do último permite inferir que os profissionais que redigiram o programa - "um amontoado de noções desconnexas, às vezes complicado num ponto pelo extremo das exigencias, ás vezes resumido em outros por descabidos propositos" (dezembro de 1909, n. 03, ano VIII, p.06) - foram Oscar Thompson, mais uma vez, e Horacio Lane, diretor da Escola Americana e participante ativo, embora de modo indireto, nos rumos da instrução pública paulista desde a Reforma "Caetano de Campos" (Souza, 1997). Ademais, o autor - à época redator-secretário do periódico verificou que a diminuição do curso das escolas-modelo e dos grupos escolares para 4 anos provocou "o vacuo de uma classe. Eis porque tudo se accumula, desordenadamente, em quatro classes" (junho de 1909, n. 02, ano VIII, p.06). A aprovação do programa foi antecedida por um parecer de uma comissão composta pelos inspetores Miguel Carmem Pinto, João Lourenço Rodrigues e Domingos de Paula e Silva. Na avaliação deles, era preciso que o programa fosse complementado por um manual, que fornecesse ao professor, com detalhes, o método a ser seguido no ensino de cada matéria. Assim, além de evitar que cada professor ensinasse ao seu modo, seriam esclarecidos alguns pontos do programa de ensino tidos como vagos (Souza, 1997). Ao que parece, esse manual foi produzido, pois Carvalho mencionava que a própria Inspetoria Geral reconheceu que Lane e Thompson agiram

impensadamente ou antes precipitadamente, sem a reflexão necessaria em um trabalho tão serio e de subida, indiscutivel importancia. Foi por isso que, a titulo de experiencia, aquella auctoridade de ensino fel-o intercalado de instrucções, que nada mais significam sinão um programma no programma! (grifos do autor; dezembro de 1909, n. 03, ano VIII, p.06).

Antes mesmo da veiculação dessa série de artigos escritos por Carvalho, na seção

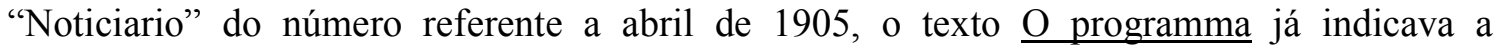
resistência dos colaboradores do periódico em aceitar o novo programa de ensino:

Está publicado e entrará em execução, á 15 de Maio, o novo programma para os grupos escolares.

Louvamos a boa vontade do actual sr. Secretario do Interior, quando trata de reformar esse chaos de leis, regulamentos e programmas de ensino; mas acreditamos que s. exc. não foi feliz ainda desta vez, porquanto o novo programma, apezar de mais simplificado que os anteriores, apresenta deficiencias, lacunas e má distribuição das materias, sem embargo da indiscutivel competencia da commissão que o organisou.

É que o defeito é da doutrina pedagogica que o governo tem procurado praticar.

Além disso, as escolas isoladas, que por muito tempo não poderão deixar de 
existir, foram votadas ao esquecimento, parecendo-nos que nellas se continuará a observar o programma antigo, donde resulta que nestas o ensino deverá ser muito mais desenvolvido que nos grupos escolares, o que toca ás raias do absurdo (n. 01 , ano IV, p.630).

Arthur Breves, à época presidente da "Associação Beneficente do Professorado Público de São Paulo", entidade responsável pela Revista de Ensino, também encontrava problemas no programa de ensino de 1905 , sendo o principal deles o fato de que ele era

(...) em muitos pontos, inferior aos do tempo da monarchia.

Por elle se vê que, no quarto e ultimo anno dos grupos, em arithmetica o alumno só chega até fracções, quando os estudados em escolas isoladas antes de 15 de Novembro, iam até ás proporções e ás regras de tres, simples e composta, juro, desconto, sociedade e cambio, sem duvida conhecimentos de muita utilidade pratica.

(...) A respeito de algebra, não se encontram nos programmas nem as quatro operações: entretanto, nas escolas régias, o ensino chegava até ás equações do $1^{\circ}$. (grifo do autor; Ensino nos grupos. In: Revista de Ensino, janeiro de 1906, n. 04, ano IV, p.753-754).

Pouco tempo depois, Breves voltou a insistir na inadequação do programa:

Basta uma rapida leitura desse trabalho pedagogico para uma pessôa imparcial chegar á conclusão de que nelle os diversos estudos não se concatenam logicamente, concorrendo para o desenvolvimento methodico, salutar, racional e razoavel, das faculdades intellectuaes dos alumnos.

Ha nelle incongruencias que á primeira vista se descobrem; disciplinas, cujo apprendizado apenas se inicia, abandonando-se por completo o que ellas possuem de mais valor e alcance pratico; o prurido de especificar e exemplificar processos de ensino, incompativeis com o objecto de um programma de tal natureza, que só deve enumerar as materias a leccionar e o quantum de cada uma (...) ( $\underline{\mathrm{O} \text { programma nos }}$ grupos escolares. In: Revista de Ensino, maio de 1906, n. 06, ano IV, p.835).

Convém recordar aqui que, no período no qual foram publicadas todas essas posições contrárias ao programa de ensino das escolas-modelo e dos grupos escolares, a "Associação" vivia seu momento mais ativo. Se na fase em que ainda recebia subsídio oficial (abril de 1902 - dezembro de 1904), a Revista de Ensino já não se mantinha indiferente à política educacional conduzida pelo Estado, entre fevereiro de 1905 e março de 1910, quando teve de ser produzida de modo independente em função das divergências com a Secretaria do Interior $^{80}$, "houve uma radicalização de opiniões, mas apenas no sentido de que se passou a

${ }^{80}$ Carlos da Silveira, redator-chefe da revista Educação, escreveu para o periódico um artigo intitulado Apontamentos para uma história do ensino público em São Paulo - revistas de ensino (junho de 1929, n. 03, vol. VII, p.323-332). Nele, o autor explica que as desavenças entre a "Associação" e a "Secretaria" começaram no final de 1903, quando "houve o celebre desconto de $15 \%$ sobre os vencimentos dos funccionarios publicos estaduaes; a irritação provocada por esta medida, já de si muito antipathica, foi extraordinariamente aggravada pela reforma do ensino de 1904. O Prof. Arthur Breves, presidente da Associação Beneficente do Professorado Publico, entrou a fazer critica cerrada ás duas leis, não só pelas columnas de 'A Platea', como tambem pelas paginas da propria 'Revista de Ensino'. A Associação Beneficente manifestou-se solidaria com a attitude do seu presidente, apoiando-o numa campanha que reputavam justissima. E isso determinou que o 'Diario Official' 
apontar com mais insistência e menores cuidados retóricos, o que se considerava errado no tocante à escola pública e à administração das questões de ensino" (Catani, 2003, p.26). No caso de Arthur Breves, um de seus principais objetos de questionamento, além das condições de trabalho e de remuneração dos professores, era o programa de ensino de 1905.

O exame das considerações dos autores deixa transparecer, todavia, que o incômodo decorria mais daquilo que, para eles, era inconcebível: o novo programa era mais simplificado do que o adotado pelas escolas isoladas. Com efeito, de acordo com o inspetor escolar João Crysostomo Bueno dos Reis Junior, a despeito da orientação legal de que o programa de 1904 devia ser estendido a elas,

até hoje se procura observar, nas escolas isoladas, o exorbitante e difficilimo programma annexo ao regimento interno de 1894 . Somos dos que pensam que as escolas isoladas devem ter um programma especial, mas, emquanto isto não se verificar, que se observe (...) o que baixou com o dec. n. 1217 de 29 de Abril de 1904, incomparavelmente, mais exequivel e mais practico (Anuários do Ensino do Estado de São Paulo de 1909-1910, p.248).

Em quatro relatórios datados do período entre 1899 e 1902, o inspetor escolar Francisco Pedro do Canto também ressaltou as dificuldades da execução, nas escolas isoladas, do programa de ensino de 1894. No entender dele, era "impossivel a um só professor e quando mesmo com adjunto transmitir convenientemente e com proveito o ensino aos seus alumnos" (1899, Ordem 7105). Somavam-se a isso as más condições materiais desses estabelecimentos, dado que funcionavam, em sua maioria, "em salas acanhadas e sem os materiaes de ensino necessario" (1900, Ordem 7025). Urgia, nesse sentido, modificar o programa, de modo a ajustá-lo ao papel das escolas isoladas: "São as nossas escolas ruraes, escolas para o povo, escolas dos pobres. Ler, escrever e contar é o que importa sobretudo que o povo saiba. Quando tivermos conseguido isso teremos dado um grande passo no caminho do progresso" (1900, Ordem 7025). Em outros termos,

(...) em grande parte, os pais de familia, quando os filhos lêm, escrevem e contam sobre numeros inteiros, retiram-nos da escola; os pobres, porque precisam que os ajudem a satisfaser as necessidades da vida; os ricos, porque os destinam a estudos superiores. É a razão pela qual raro é o alumno que na roça conclue os estudos do programma das escolas preliminares, muito bonito, modelado pelo plano dos paizes mais adiantados da Europa, porem que entre nos, nas povoações ruraes, ainda é cedo para executal-o (1899, Ordem 7105).

recebesse, do gabinete do Secretario do Interior de então, um simples aviso para não mais cuidar da 'Revista de Ensino"” (1929, p.325). 
Muitos outros inspetores escolares partilhavam da opinião de Canto. Para José Carneiro da Silva, por exemplo, a subdivisão de cada um dos 4 anos do curso em duas séries, determinada pelo programa de 1894, fazia com que o ensino nas escolas isoladas fosse mais longo do que o dos grupos escolares, o que gerava um "facto anomalo que, bem analysado, compromette o preconisado renome do nosso aparelho escolar. Os professores, na sua maior parte, promovendo nos exames finaes os alumnos de uma para outra série do mesmo anno, convertem em 8 annos o curso" (Anuários de 1908-1909, p.48).

Não sendo beneficiados com as classes homogêneas presentes nos grupos escolares, os professores das escolas isoladas, na perspectiva do inspetor escolar Antonio Morato de Carvalho, deviam guiar seu trabalho através de um programa limitado, que abrangesse apenas

\footnotetext{
a aprendisagem indispensavel, sem preoccupações de somenos vantagens para aquelles que nenhuma aspiração tem para a carreira de letras. Em nosso meio, mormente pelo interior do Estado, deveriamos nos approximar das escolas mantidas pela 'Sociedade de Instrucção Elementar' de Liége, cujo programma é: procurar dar ás classes inferiores o genero de educação intellectual e moral mais apropriadas ás suas necessidades (Anuários de 1909-1910, p.240).
}

Os apelos dos inspetores escolares foram atendidos somente em 1911. O Decreto $\mathrm{n}$. 2005, de 13 de fevereiro, aprovou e mandou observar o programa de ensino para as escolas isoladas do Estado. Na apreciação do inspetor Domingos de Paula e Silva, ele, sendo "mais practico e exequivel que o então seguido, veio em parte sanar difficuldades" (Anuários de 1910-1911, p.83). O elenco de matérias compreendia a "Leitura; Linguagem; Arithmetica; Historia; Geographia; Sciencias naturaes (Animaes, Plantas e Lições geraes); Calligraphia; Desenho; Canto; Trabalho manual; Gymnastica”. O programa era, pois, mais reduzido que aquele dos grupos escolares em vigor no mesmo período, já que não previa o ensino de Geometria, de Ciências físicas, de Instrução cívica e moral e de Exercícios militares. No final do documento, há observações sobre como o professor devia conduzir o ensino das seguintes matérias: Aritmética, História, Geografia, Ciências Naturais, Caligrafia e Desenho. A inferioridade do ensino planejado para as escolas isoladas também refletia-se na duração do curso, de apenas 3 anos. Como sempre, elas foram, novamente, relegadas a favor das escolasmodelo e dos grupos escolares. 


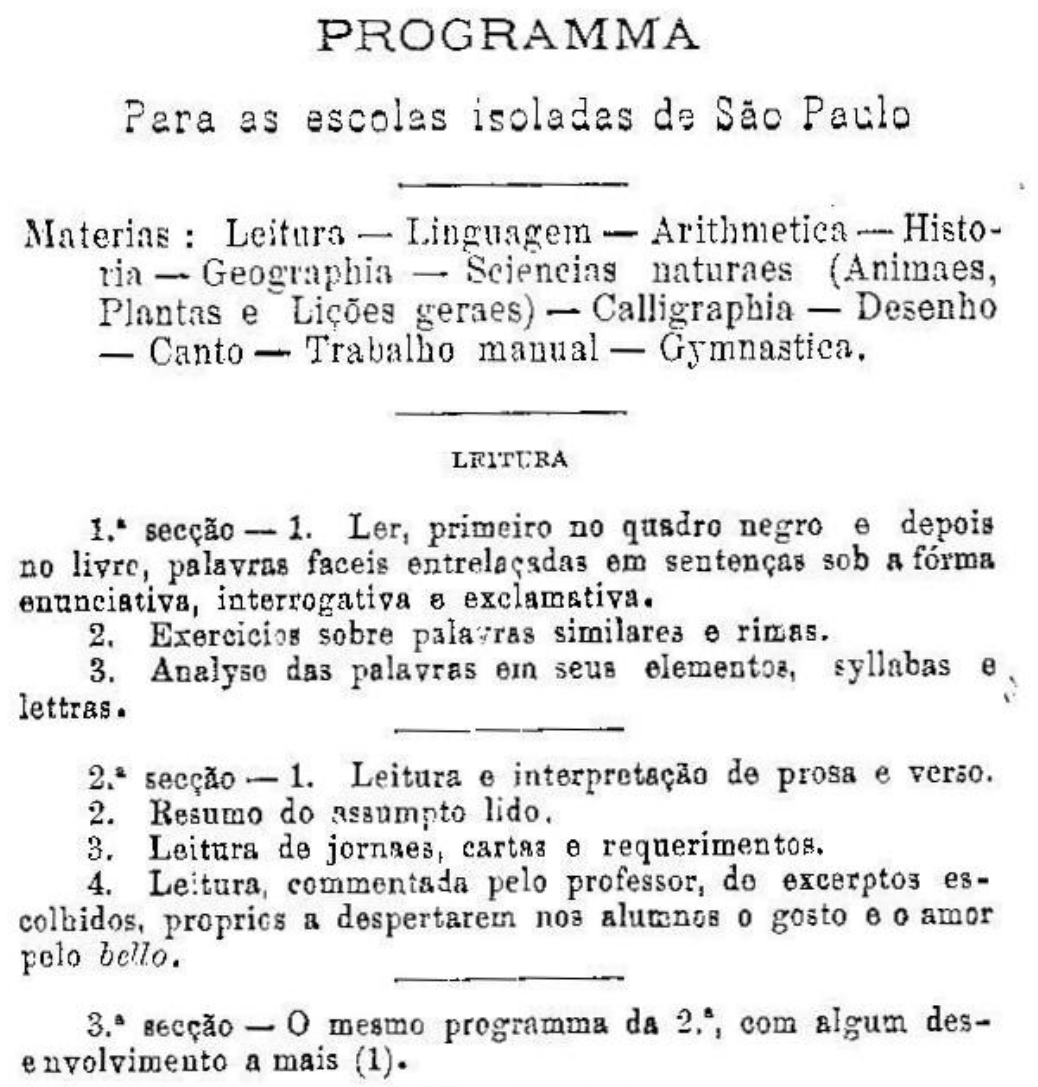

FIGURA 4 - Programa de ensino das escolas isoladas (1911)

Como é possível notar, ao contrário dos programas de ensino direcionados às escolasmodelo e aos grupos escolares, nesse que foi criado para as escolas isoladas, as matérias e seus respectivos conteúdos foram distribuídos não pelos anos de duração do curso, mas por seções. Se nos grupos escolares o ensino era graduado em séries consecutivas, cada uma delas correspondendo a um ano letivo, nas escolas isoladas, as dificuldades do professor em lidar, numa mesma classe, com alunos de diferentes níveis de adiantamento, levaram à divisão das crianças em seções homogêneas, em número igual ao dos anos de duração do curso. Desse modo, enquanto uma das seções estivesse recebendo atenção do professor, as demais manteriam-se ocupadas com outras atividades (Gallego, 2003, p.123).

Ao que tudo indica, o Decreto n. 2005 foi antecedido pelo Decreto n. 2004, de 13 de fevereiro de 1911, que aprovou o Regimento Interno das escolas-modelo isoladas anexas à Escola Normal de São Paulo. Isso porque, nos Anuários de 1909-1910, o inspetor escolar Antonio Morato de Carvalho relata que havia, na Capital, 
(...) produzindo apreciaveis fructos, uma escola destinada a servir de modelo às isoladas. Nessa, porém, o ensino vasado em moldes modernos e proficientemente ministrado, obedece a um programma especial e reduzido, ao passo que, nas escolas isoladas, o programma é differente, abrangendo grande numero de disciplinas, o que só póde trazer peias á actividade e á dedicação do professor novel. (...) Medidas efficazes para tal fim seriam talvez as seguintes: (...) simplificar o programma de estudos do curso preliminar, que deverá ser o mesmo da escola isolada que lhe serve de modelo (p.240).

O autor do relatório referia-se ao Decreto n. 2004, de 13 de fevereiro de 1911, que aprovou o Regimento Interno das escolas-modelo isoladas anexas à Escola Normal de São Paulo. Conforme o Artigo $3^{\circ}$., o "curso das escolas-môdelo isoladas comprehenderá as materias constantes do annexo n.1, distribuido por tres secções, a primeira das quaes poderá ser subdividida em duas classes: $a$ e $b$ ". O anexo em questão consistia no quadro-horário abaixo:

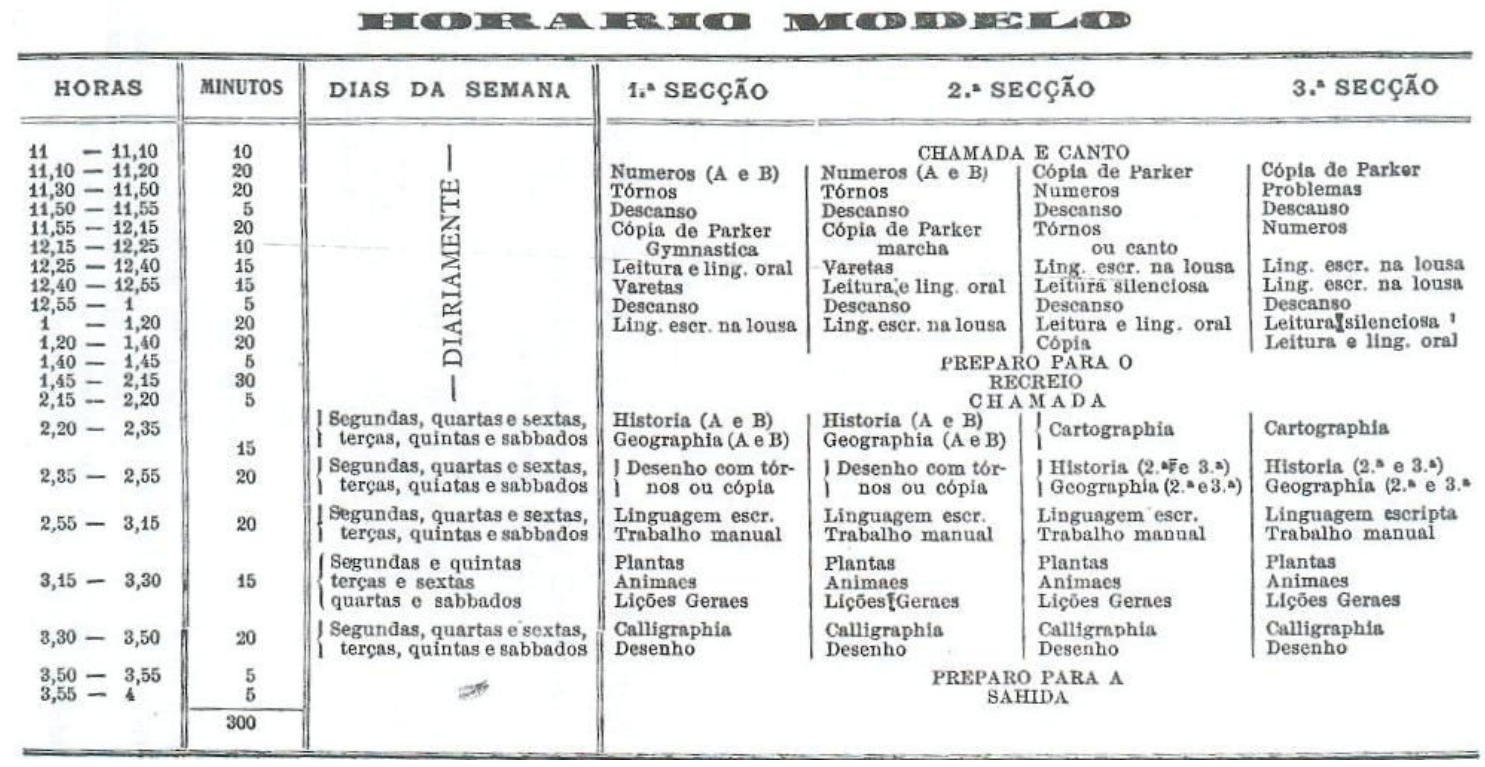

FIGURA 5 - Horário-modelo das escolas-modelo isoladas (1911)

A comparação do programa de ensino das escolas isoladas com esse horário-modelo mostra que as matérias eram basicamente as mesmas, o que condiz com a sugestão de Carvalho de que o primeiro fosse semelhante àquele da escola-modelo isolada. Contudo, é possível observar que no horário aparecem os conteúdos de Aritmética (números e cópia de Parker) e não a matéria propriamente dita. Além disso, algumas matérias, tais como Leitura e 
Linguagem oral, deviam ser ensinadas simultaneamente ( $2^{\mathrm{a}}$. seção), fato que revela a dificuldade em se organizar o trabalho na escola isolada, cujos professores deviam conduzir simultaneamente as três seções (Esteves, 2002, p.60). Antes de 1911, os Anuários do Ensino de 1909-1910 já haviam publicado um horário-modelo para as escolas isoladas, o qual, no entanto, é semelhante àquele incluído no Decreto n. 2004. Vale recordar que eram os próprios professores das escolas isoladas que confeccionavam seus horários antes da obrigatoriedade em cumprir os horários-modelo, a partir do início do século XX (Gallego, 2003).

Reforçando o processo de diferenciação dos programas de ensino em curso, o Decreto n. 2225, de 16 de abril de 1912, tornou a publicar aquele aprovado pelo Decreto n. 2005, de 13 de fevereiro de 1911 (para as escolas isoladas) e pelo Decreto n. 1281, de 24 de abril de 1905 que, agora, além de ser dirigido às escolas-modelo e aos grupos escolares, devia ser estendido às escolas reunidas, já que elas eram obrigadas a adotar o "regimen, methodo e processos de ensino dos grupos-escolares" (Artigo 103). Logo após, o Decreto n. 2368, de 14 de abril de 1913, aprovou o Regulamento das escolas de bairro e apresentou a elas, anteriormente denominadas de escolas isoladas, um novo programa de ensino. Como no anterior, as matérias e os conteúdos a elas correlatos foram distribuídos por seções - duas, no caso, já que a duração do curso foi diminuída de 3 para 2 anos. As matérias eram "Leitura; Linguagem oral; Linguagem escripta; Arithmetica; Geographia; Historia do Brazil; Noções de cousas; Educação civica; Trabalhos manuaes; Calligraphia”. O programa, desse modo, em relação ao anterior, sofreu algumas descontinuidades, uma vez que foram excluídas as Ciências naturais, o Desenho, o Canto e a Ginástica. Por outro lado, foi introduzido o ensino de Noções de coisas e de Educação cívica e a matéria Linguagem foi dividida em Linguagem oral e Linguagem escrita. 
PROGRAMMA DE ENSINO

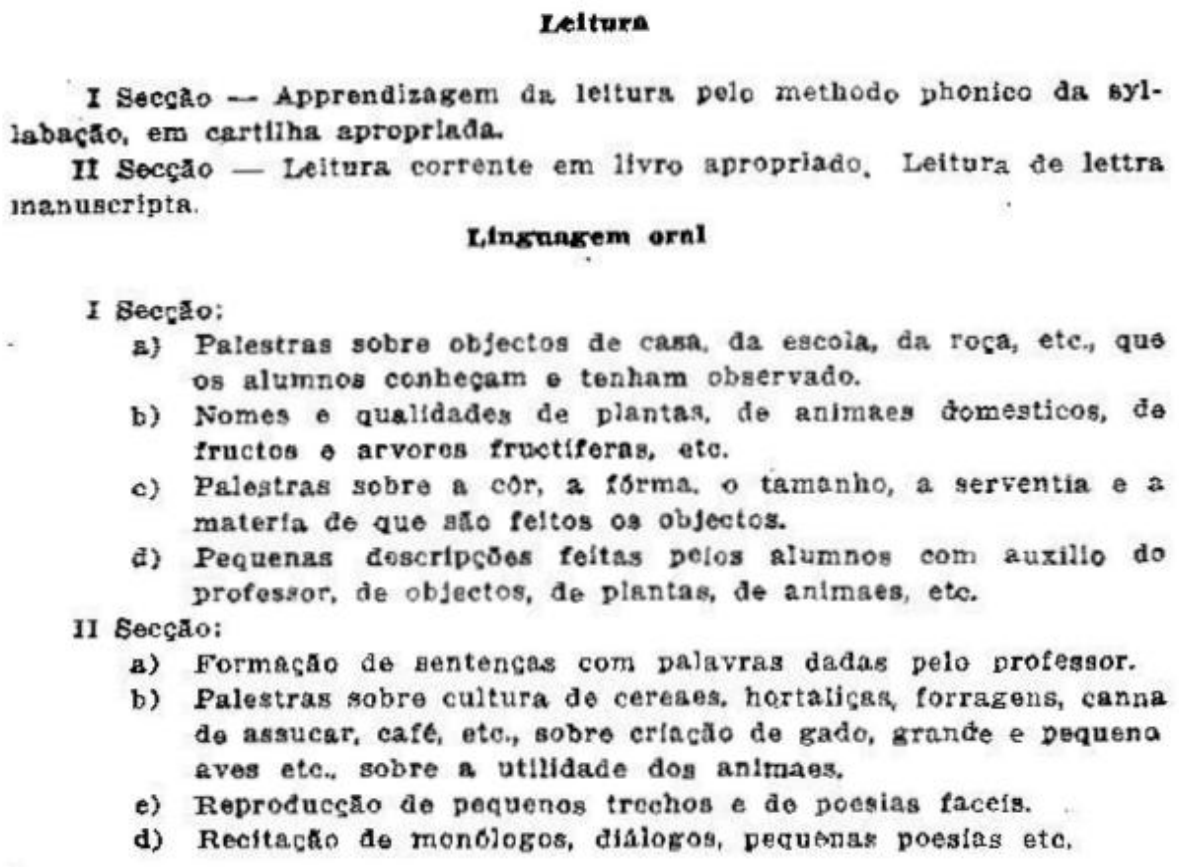

FIGURA 6 - Programa de ensino das escolas de bairro (1913)

Anos depois, no Decreto n. 2944, de 08 de agosto de 1918, que regulamentou a Lei n. 1579, de 19 de dezembro de 1917, foram incluídos, sob a forma de anexos, quatro novos programas de ensino ${ }^{81}$ : para as escolas isoladas rurais, para as escolas isoladas distritais, para as escolas isoladas urbanas e para os grupos escolares. Nesse último caso, cujo curso devia durar 4 anos, o rol de matérias era formado pela "Leitura; Linguagem oral; Linguagem escripta; Calligraphia; Arithmetica; Geometria; Geographia; Historia do Brasil; Instrucção moral e civica; Sciencias Physicas e naturaes - Hygiene; Musica; Desenho; Trabalho manual; Gymnastica; Economia domestica". Do programa anterior foram excluídos, então, os Exercícios militares, desmembrada a Linguagem (Linguagem oral e Linguagem escrita) e acrescentada, no $3^{\circ}$. ano do curso, a Economia doméstica, chamada de Educação doméstica e puericultura no $4^{\circ}$. ano. Ademais, a Ginástica, antes presente em todos os anos, devia ser ensinada só até o $3^{\circ}$. ano. A forma de apresentação dos saberes escolares foi mantida, isto é, para cada um dos anos do curso são descritos os conteúdos de todas as matérias.

Nas escolas isoladas rurais, distritais e urbanas, a duração do curso era, respectivamente, de 2, 3 e 4 anos. Nos Anuários do Ensino de 1917, é possível encontrar

\footnotetext{
${ }^{81}$ Eles podem ser encontrados nos Anuários do Ensino de 1918.
} 
quais foram os critérios utilizados para distinguir os programas: "A lei n.1579, de 19 de dezembro de 1917, dividiu as escolas isoladas em tres grandes categorias: urbanas, districtaes e ruraes. Para cada uma dessas categorias foi organizado, pelo poder competente, programmas de ensino, de accôrdo com as necessidades da zona em que ellas tem de servir” (p.402). Os Anuários de 1918 também confirmam que os programas de ensino foram adequados às finalidades de cada escola, já que essa deve

(...) educar as novas gerações para o meio que lhes serve de 'habitat'.

A lei n. 1579, de 19 de Dezembro de 1917, parece ter tido em vista esse desideratum quando dividiu as escolas em ruraes, districtaes e urbanas, dando a cada uma dessas especies um programma adequado ás necessidades que devem ser por ellas satisfeitas.

As escolas ruraes fornecerão uma educação rural ou industrial, segundo funccionem em um centro industrial ou em um centro agricola.

As escolas districtaes collimarão outros fins e as escolas urbanas terão em vista a vida das cidades em toda a sua complexidade.

O fim principal da educação é a formação do espirito da criança, tornando-a apta para a vida completa. Mas este objectivo é todo relativo e apresenta uma gradação e variedade, desde a vida dos campos até a das cidades (p.743).

As escolas isoladas rurais e distritais deveriam ministrar "Leitura; Linguagem oral; Linguagem escripta; Arithmetica; Geographia; Historia do Brazil; Sciencias physicas e naturaes-Hygiene; Instrucção moral e civica; Trabalhos manuaes; Musica; Calligraphia; Geometria; Desenho; Gymnastica". O mesmo devia ser observado pelas escolas isoladas urbanas, exceto pela inclusão do ensino de Economia doméstica, chamada de Educação doméstica a partir do $2^{\circ}$. ano. Aos três subtipos de escolas isoladas eram prescritas, dessa forma, as mesmas matérias do programa de ensino dos grupos escolares. Outro ponto em comum era a distribuição dos conteúdos que, ao contrário do que ocorria até então, passou a ser feita não mais por seções, mas por anos. A diferença entre os quatro programas estava, portanto, nos conteúdos e na extensão deles.

O Decreto n. 2944, de 08 de agosto de 1918, foi o último documento a apresentar programas de ensino específicos para cada tipo de escola, antes da Reforma Sampaio Dória, de 1920. Embora o processo de diferenciação dos programas tenha sido retomado em 1926, quando a Lei responsável pela medida foi revogada (n. 1750, de 08 de dezembro de 1920), essa estabeleceu um programa único para os grupos escolares, as escolas reunidas e as escolas isoladas. A Reforma, nesse sentido, pode ser considerada um marco divisor, o que exige relembrar a trajetória dos programas do ensino primário no período entre 1905 e 1918 : 
TABELA 13

\begin{tabular}{|c|c|c|}
\hline $\begin{array}{c}\text { Documento no qual o } \\
\text { programa de ensino foi } \\
\text { inserido }\end{array}$ & $\begin{array}{c}\text { Tipo de } \\
\text { escola primária ao qual o } \\
\text { programa se destinava }\end{array}$ & $\begin{array}{l}\text { Duração } \\
\text { do curso }\end{array}$ \\
\hline $\begin{array}{l}\text { Decreto n. } 1281 \text {, de } 24 \\
\text { de abril de } 1905\end{array}$ & $\begin{array}{l}\text { Escolas-modelo e grupos } \\
\text { escolares }\end{array}$ & 4 anos \\
\hline $\begin{array}{c}\text { Decreto n. 2004, de } 13 \\
\text { de fevereiro de } 1911\end{array}$ & Escolas-modelo isoladas & 3 anos \\
\hline $\begin{array}{c}\text { Decreto n. } 2005 \text {, de } 13 \\
\text { de fevereiro de } 1911\end{array}$ & Escolas isoladas & 3 anos \\
\hline $\begin{array}{l}\text { Decreto n. } 2225 \text {, de } 16 \\
\text { de abril de } 1912\end{array}$ & $\begin{array}{c}\text { Escolas-modelo, grupos } \\
\text { escolares e escolas reunidas }\end{array}$ & 4 anos \\
\hline $\begin{array}{l}\text { Decreto n. } 2225 \text {, de } 16 \\
\text { de abril de } 1912\end{array}$ & Escolas isoladas & 3 anos \\
\hline $\begin{array}{l}\text { Decreto n. } 2368 \text {, de } 14 \\
\text { de abril de } 1913\end{array}$ & Escolas de bairro & 2 anos \\
\hline $\begin{array}{l}\text { Decreto n. } 2944 \text {, de } 08 \\
\text { de agosto de } 1918\end{array}$ & Grupos escolares & 4 anos \\
\hline $\begin{array}{l}\text { Decreto n. } 2944 \text {, de } 08 \\
\text { de agosto de } 1918\end{array}$ & Escolas isoladas rurais & 2 anos \\
\hline $\begin{array}{l}\text { Decreto n. 2944, de } 08 \\
\text { de agosto de } 1918\end{array}$ & Escolas isoladas distritais & 3 anos \\
\hline $\begin{array}{l}\text { Decreto n. } 2944 \text {, de } 08 \\
\text { de agosto de } 1918\end{array}$ & Escolas isoladas urbanas & 4 anos \\
\hline
\end{tabular}

Alarmado com os altos índices de analfabetismo no Estado de São Paulo, mas preocupado com a escassez de recursos, Sampaio Dória, sucessor de Oscar Thompson na Diretoria Geral da Instrução Pública, organizou uma Reforma na Instrução Pública do Estado. Regulamentada pelo Decreto n. 3356, de 31 de maio de 1921, ela reduziu para 2 anos o curso primário, a ser ministrado nos grupos escolares, nas escolas reunidas e nas escolas isoladas. Além disso, a obrigatoriedade e a gratuidade escolar passaram a ser extensivas às crianças de 9 e 10 anos de idade, e não àquelas entre 7 e 12 anos, como antes. Com essas iniciativas, o "que o Governo de São Paulo visou (...) foi alphabetizar todas as creanças que attinjam á idade escolar obrigatoria, fornecendo-lhes egual qualidade e egual quantidade de ensino, quer se trate das creanças da cidade, quer se trate das creanças da zona rural" (Anuários de 1923, p.80). Além do combate ao analfabetismo, o outro intuito de Dória - fortemente influenciado pelos ideais nacionalistas que se disseminaram pelo país na segunda década do século XX era nacionalizar os imigrantes (Nagle, 1974; Antunha, 1976).

Foi necessária, assim, a elaboração de um novo programa de ensino, incluído no Artigo 101 do Decreto n. 3356 e composto pelas seguintes matérias: "Leitura (analytica, para o $1^{\circ}$. ano); Linguagem oral; Linguagem escripta; Arithmetica; Geometria; Geographia; 
Historia do Brasil; Sciencias physicas e naturaes - Hygiene; Instrucção moral e civica; Desenho; Musica; Trabalhos manuaes; Exercicios Gymnasticos; Calligraphia”. Cumpre sublinhar que, no $1^{\circ}$. ano, há a junção das matérias Geografia e História e não estava previsto o ensino de Caligrafia. Por outro lado, no $2^{\circ}$. ano não seriam ensinados Música e Exercícios Ginásticos. Quanto à forma de apresentação dos saberes escolares, não há alterações, ou seja, para cada um dos 2 anos do curso são descritos os conteúdos de todas as matérias.

Fortemente criticados, o adiamento da freqüência obrigatória da criança na escola e a modificação nos programas de ensino em voga receberam justificativas de teor psicopedagógico (Nagle, 1974, p.209), como é possível depreender do texto dos Anuários do Ensino de 1923 intitulado Os programmas de ensino de S. Paulo e a idade escolar, de Romano Barreto: "Na impossibilidade de o Governo dar uma instrucção de tres ou quatro annos a todos, condensou os programmas até então existentes em dois annos apenas, tendo necessidade, para serem cumpridos, de augmentar a capacidade intellectual do alumno, exigindo das creanças de 9 a 10 annos completos" (p.62). Como resumia o autor: "Digamos que essas são as idades de melhor comprehensão, de assimilação mais prompta, de memoria intelligente e já de raciocinio" (1923, p.64).

A esses argumentos em favor da Reforma, pode ser somado o fato de que ela acabou apenas por legalizar uma situação já existente. Primeiramente, o Decreto n. 3356, ao classificar as escolas isoladas em rurais e urbanas (Artigo 95) e ao manter os 2 anos de duração do curso das primeiras, não trouxe conseqüências profundas para essas. A análise do novo programa mostra que muitos dos conteúdos prescritos em 1918 para as escolas isoladas rurais foram mantidos. Em segundo lugar, o curso de 4 anos dos grupos escolares dificilmente era concluído pelas crianças neles matriculados. Os altos índices de reprovação no $1^{\circ}$. ano e o de deserção, verificado especialmente na passagem do $2^{\circ}$. para o $3^{\circ}$. ano, atestam que, na prática, a maior parte dos alunos não ultrapassava os 2 anos de escolaridade. As classes correspondentes ao $3^{\circ}$. e ao $4^{\circ}$. anos, em outras palavras, eram formadas por um reduzido grupo de alunos privilegiados, que triunfaram num ensino marcadamente seletivo e exigente. Isso explica por que esses dois últimos anos foram transformados num curso de ensino médio, de 2 anos, a ser oferecido pelos grupos escolares e pelas escolas reunidas e, que, sendo pago e não obrigatório, estaria ao alcance de poucos (Nagle, 1974; Antunha, 1976; Reis Filho, 1995). 
O Decreto n. 4101, de 14 de dezembro de 1926, regulamentou a Lei n. 2095, de 24 de dezembro de 1925, que, por sua vez, aprovou o Decreto n. 3358, de 11 de junho de 1925. A partir desse, que reformou a Instrução Pública do Estado, o ensino primário voltou a ser obrigatório e gratuito para as crianças de ambos os sexos entre 7 e 12 anos de idade. Já o Decreto n. 4101 determinava que as escolas-modelo, os grupos escolares e as escolas reunidas - divididas em rurais e urbanas - deviam seguir o mesmo programa de ensino reproduzido abaixo, mas seu desenvolvimento deveria variar conforme a duração do curso, de 4 anos nos primeiros tipos de escolas e de 3 anos no terceiro:

Artigo 108 -

a) leitura e conhecimento dos preceitos de linguagem;

b) exercicios de linguagem escripta;

c) calligraphia, desenho e geometria pratica, com as noções necessarias para suas applicações communs;

d) calculo arithmetico sobre inteiros e fracções ordinarias e decimaes; systema metrico; proporções; regra de tres e suas applicações praticas;

e) noções de cosmographia e de geographia geral; de sciencias physicas e naturaes, em suas mais simples applicações á hygiene, á lavoura e ás industrias;

f) geographia do Brasil e do Estado de São Paulo;

g) Historia do Brasil e commentarios sobre a vida de seus grandes homens;

h) breves noções sobre a Constituição Federal e o Estado;

i) canto e solfejo;

j) educação moral;

k) exercicios gymnasticos e trabalhos manuaes adaptados á idade e ao sexo

Em relação às escolas isoladas - que continuaram a ser divididas em rurais e urbanas, embora seu curso tenha sido estendido para 3 anos - o programa de ensino devia conter "as materias constantes dos programmas vigentes para o $1^{\circ}$., $2^{\circ}$. e $3^{\circ}$. annos do curso primario" (Artigo 126). Possivelmente, o Decreto refere-se ao Ato de 19 de fevereiro de 1925 que, como informa Ribeiro (1996), especificou as seguintes matérias para cada um dos 4 anos do curso dos grupos escolares:

$1^{\circ}$. ano - Leitura, Caligrafia, Linguagem Oral, Linguagem Escrita, Aritmética, Formas, Desenho, Geografia, História, Instrução Moral e Cívica, Lição das Cousas, Música, Trabalhos Manuais, Ginástica;

$2^{\circ}$. ano - Leitura, Caligrafia, Linguagem Oral, Linguagem Escrita, Aritmética, Formas, Desenho, Geografia, História, Instrução Moral e Cívica, Lição das Cousas, Música, Trabalhos Manuais, Ginástica;

$3^{\circ}$. ano - Leitura, Caligrafia, Linguagem Oral, Linguagem Escrita, Aritmética, Geometria, Desenho, Geografia, História, Instrução Moral e Cívica, Ciências Físicas e Naturais, Música, Trabalhos Manuais, Ginástica;

$4^{\text {o. }}$ ano - Leitura, Caligrafia, Linguagem Oral, Linguagem Escrita, Geografia, Aritmética, Geometria, Desenho, Geografia, História, Instrução Moral e Cívica, Ciências Físicas e Naturais, Música, Ginástica. 
Como é possível notar, a matéria Formas recebeu, no $3^{\circ}$. e no $4^{\circ}$. ano, a denominação de Geometria. Já Lição das Coisas foi substituída, também nos dois últimos anos do curso, pelas Ciências Físicas e Naturais. Além disso, no $4^{\circ}$. ano não havia o ensino de Trabalhos manuais (Ribeiro, 1996).

Para finalizar a história dos programas do ensino primário até aqui realizada, o Decreto n. 4600, de 30 de maio de 1929, regulamentou a Lei n. 2269, de 31 de dezembro de 1927 e a Lei n. 2315, de 1928. Pela primeira, o curso das escolas urbanas (reunidas e isoladas) continuou a ser de 3 anos, mas nas escolas rurais (reunidas e isoladas), ele foi diminuído para 2 anos. Ademais, o ensino primário passou a ser obrigatório e gratuito para as crianças de 8, 9 e 10 anos de idade e facultativo para aquelas de 7,11 e 12. O Decreto n. 4600 estabeleceu que o "ensino nos grupos escolares, escolas urbanas e ruraes, bem como nos cursos nocturnos, obedecerá a programmas distintos para cada uma dessas categorias de escolas" (Artigo 61):

\title{
$\underline{\text { Programa de ensino dos grupos escolares }}$
}

Leitura e escripta, exercicios de redacção, caligraphia, arithmetica pratica, até proporções inclusive geometria pratica, noções uteis e intuitivas de sciencias physicas e naturaes e de physiologia e hygiene, elementos de geographia geral e do Brasil e, especialmente do Estado de São Paulo, factos de historia patria, instrucção civica, desenho, musica e cantos orpheonicos, trabalhos manuaes, escotismo para os meninos e gymnastica.

\section{$\underline{\text { Programa de ensino das escolas urbanas (reunidas e isoladas) }}$}

\begin{abstract}
Leitura e escripta, exercicios de redacção, calculo applicado a problemas da vida domestica e da industria e commercio locaes, noções de geometria pratica, conhecimentos uteis e intuitivos relativamente aos animaes, ás plantas e aos phenomenos da natureza, noções de physiologia e de hygiene, visando a saude do alumno, idéa geral do mundo e conhecimento geographico da localidade, do Brasil e do Estado de São Paulo, factos da historia patria, instrucção civica, desenho educativo, canto, trabalhos manuaes adequados á zona da escola e exercicios physicos.
\end{abstract}

\section{$\underline{\text { Programa de ensino das escolas rurais (reunidas e isoladas) }}$}

Leitura e escripta, exercicios de redacção, calculo applicado a questões de interesse local, conhecimentos uteis e intuitivos relativamente aos animaes, ás plantas e aos phenomenos da natureza, noções de physiologia e de hygiene, visando a saude do alumno, conhecimento geographico da localidade, do Brasil em geral e do Estado de São Paulo, factos da historia patria, instrucção civica, desenho educativo, canto, trabalhos manuaes adequados á zona da escola e exercicios physicos.

O confronto entre os três programas permite observar que a Caligrafia, a Música e o escotismo estavam presentes apenas no ensino dos grupos escolares. Além disso, enquanto 
neles foi incluída a Aritmética prática, nas escolas urbanas e nas escolas rurais devia ser ministrado, respectivamente, o cálculo aplicado a problemas da vida doméstica e da indústria e comércio locais e o cálculo aplicado a questões de interesse local. Por fim, nas escolas rurais, ao contrário das urbanas, não estava previsto o ensino de noções de geometria prática $\mathrm{e}$ de idéia geral do mundo.

O quadro a seguir apresenta os últimos programas de ensino publicados na década de 1920:

TABELA 14

\begin{tabular}{|c|c|c|}
\hline $\begin{array}{c}\text { Documento no qual o } \\
\text { programa de ensino foi } \\
\text { inserido }\end{array}$ & $\begin{array}{c}\text { Tipo de } \\
\text { escola primária ao qual o } \\
\text { programa se destinava }\end{array}$ & $\begin{array}{l}\text { Duração } \\
\text { do curso }\end{array}$ \\
\hline $\begin{array}{c}\text { Decreto n. } 4101 \text {, de } 14 \\
\text { de dezembro de } 1926\end{array}$ & $\begin{array}{l}\text { Mesmo programa com } \\
\text { desenvolvimento diferente: } \\
\text { escolas-modelo, grupos } \\
\text { escolares e escolas reunidas } \\
\text { (rurais e urbanas) } \\
\text { Outro programa: escolas } \\
\text { isoladas (rurais e urbanas) }\end{array}$ & $\begin{array}{c}\text { Escolas-modelo e } \\
\text { grupos escolares: } 4 \\
\text { anos } \\
\text { Escolas reunidas } \\
\text { (rurais e urbanas) e } \\
\text { escolas isoladas } \\
\text { (rurais e urbanas): } 3 \\
\text { anos }\end{array}$ \\
\hline $\begin{array}{l}\text { Decreto n. } 4600 \text {, de } 30 \\
\text { de maio de } 1929\end{array}$ & $\begin{array}{c}\text { Programas diferentes: } \\
\text { grupos escolares, } \\
\text { escolas urbanas (reunidas e } \\
\text { isoladas) e escolas rurais } \\
\text { (reunidas e isoladas) }\end{array}$ & $\begin{array}{l}\text { Grupos escolares: } 4 \\
\text { anos } \\
\text { Escolas urbanas: } 3 \\
\text { anos } \\
\text { Escolas rurais: } 2 \text { anos }\end{array}$ \\
\hline
\end{tabular}


Concluído esse retrospecto dos programas do ensino primário elaborados de 1887 a 1929 no Estado de São Paulo, cumpre tecer algumas considerações. A primeira delas é a de que, à exceção dos programas de 1892, 1894 e 1905, não foi possível identificar os autores dos demais ${ }^{82}$. A esse respeito, é esclarecedora a afirmação de Chartier\&Hébrard (1995, p.251) de que os "textos oficiais pertencem a um corpus por direito anônimo e precisamente localizado, ainda que, de vez em quando, certos atores privilegiados (os inspetores-gerais, por exemplo) enunciem também normas em seu próprio nome”. A leitura da legislação escolar indica, no entanto, que eram as autoridades educacionais quem deviam criar e aprovar os programas. Assim, o Decreto n. 144-B, de 30 de dezembro de 1892, definia que, ao Conselho Superior, competia "organizar definitivamente os programas de ensino" (Artigo $22 \S 3^{\circ}$.). Ao que parece, com a extinção do Conselho Superior, em 1897, tal responsabilidade teve de ser transferida, como mostra o Decreto n. 1239, de 30 de setembro de 1904: "Os programmas de ensino serão os que o governo determinar e organizados pelo inspector geral do ensino" (Artigo 31). Segundo o Decreto n. 4101, de 14 de dezembro de 1926, por sua vez, o Secretário do Interior devia "approvar os programmas de ensino para as escolas preliminares" (Artigo 7) e aos inspetores gerais cabiam "organizar horarios e programmas de ensino (Artigo $14 \S 3^{\circ}$. ) $^{83}$. O Decreto n. 4600, de 30 de maio de 1929, manteve tais disposições. Apesar da dificuldade em nomear os responsáveis pelos programas, vale lembrar que Oscar Thompson esteve envolvido na concepção de dois deles: o das escolas preliminares (1894) e aquele das escolasmodelo e dos grupos escolares (1905). Formado pela Escola Normal da Capital, após um período de dois anos como adjunto de Miss Márcia Browne na direção da seção masculina da Escola-Modelo do Carmo (2 $2^{\mathrm{a}}$. Escola-Modelo), ele assumiu o cargo de diretor do mesmo estabelecimento em 1894, nele permanecendo até 1897. De 1901 a 1920, Thompson foi diretor da Escola Normal da Capital, sendo que, ao longo desse período, fez não só viagens de estudos e observação ao exterior, como ainda foi Diretor Geral da Instrução Pública por duas gestões (1909-1911 e 1917-1920) (Gonçalves\&Warde, 2002). À época da publicação dos dois programas, portanto, não lhe faltava conhecimento e experiência na área da educação pública. Entretanto, como mencionado antes, os colaboradores da Revista de Ensino não lhe pouparam críticas quando o programa de 1905 entrou em vigor.

\footnotetext{
${ }^{82}$ Sobre o programa de 1887 e o de 1890, a única informação disponível é a da participação de Rangel Pestana.

${ }^{83}$ Os inspetores gerais eram auxiliares do Diretor Geral da Instrução Pública e deveriam ser "nomeados pelo Governo, mediante proposta do Director Geral da Instrução Publica, dentre os inspectores do ensino" (Art. 13 do Decreto n. 4101, de 14 de dezembro de 1926).
} 
Outro ponto que merece ser ressaltado é o de que foram apenas três os programas de ensino publicados no âmbito de reformas, quais sejam, o de 1890 (Reforma "Caetano de Campos”), o de 1892 (Primeira Reforma Geral da Instrução Pública) e o de 1921 (Reforma Sampaio Dória). Por isso, as reformas no ensino não foram o fator determinante para a (re)formulação dos programas de ensino. Por outro lado, ao que tudo indica, não havia critérios claros para tal, como, por exemplo, uma periodicidade fixa. Os programas, ao contrário, foram produzidos em intervalos extremamente irregulares. Apesar disso, foi possível constatar que alguns deles surgiram em função de mudanças no número de anos do curso primário. Foi o caso do programa das escolas-modelo e dos grupos escolares de 1905 e dos diferentes programas de 1926: em 1904, a duração do curso daqueles dois estabelecimentos de ensino havia sido reduzida de 5 para 4 anos e, em 1925, a desigualdade na duração dos cursos foi restabelecida. A relação estreita entre tempo e programas de ensino também pode ser verificada em 1911 (escolas isoladas), 1913 (escolas de bairro), 1918 (escolas isoladas rurais, distritais e urbanas) e 1921 (grupos escolares, escolas reunidas e escolas isoladas), anos nos quais a duração do curso e os programas de ensino sofreram, concomitantemente, alterações.

Vale destacar também o vínculo entre as intervenções na forma gráfica dos programas de ensino e no modo de apresentação dos saberes escolares. Entre 1887 e 1893, os programas apenas descreviam as matérias, através de "Artigos" das leis e dos decretos, o que lhes conferia pouca visibilidade. A partir de 1894 e até 1921, os programas passaram a detalhar os conteúdos das matérias e a ser publicados sob a forma de anexos ou então através de decretos voltados especialmente para aprová-los. Essa dupla inovação revela a intenção do Estado em regular ainda mais a atividade dos professores. Isso porque, anteriormente, era muito provável que eles pouca atenção prestassem aos programas, já que esses estavam dispostos em meio a uma profusão de outros "Artigos". Além disso, a simples menção das matérias tornava as prescrições um tanto vagas, o que sujeitava os programas a interpretações diversas por parte daqueles profissionais. Com o aumento no nível de normatização, os autores dos programas não somente conduziam os docentes a lê-los com mais cuidado, como ainda diminuía os riscos deles ensinarem o que não deviam. A iniciativa em se conceder um grande espaço aos programas de ensino na legislação escolar, todavia, arrefeceu-se naqueles publicados em 1926 e em 1929, anos em que se assistiu ao retorno ao que havia antes de 1894. Por outro lado, começaram a ser produzidos, além dos programas, outros impressos voltados a complementálos, tais como o já referido Ato de 19 de fevereiro de 1925 que, além das matérias a serem 
oferecidas em todos os anos do curso dos grupos escolares, também trazia as orientações metodológicas sobre o ensino de cada uma delas ${ }^{84}$. A propósito, cabe recordar o fato de que, embora em minoria, determinados programas de ensino não apresentavam apenas matérias e conteúdos: o de 1887 ( $1^{\circ}$. grau do ensino primário) e, especialmente, o de 1904 (escolasmodelo e grupos escolares) e o de 1911 (escolas isoladas) são exemplos claros de que, entremeados aos saberes escolares, estavam recomendações ao professor sobre como ensinálos.

Por último, importa assinalar a história individual dos programas de ensino de cada uma das diferentes escolas primárias investigadas. Aqueles das escolas-modelo - a despeito de uma de suas funções ter sido a de servir como referência de organização para as demais escolas primárias - só deviam ser adotados pelos grupos escolares. Assim, ao longo do período - à exceção dos anos de 1918, de 1921 e de 1929, cujos novos programas não contemplaram as escolas-modelo - em ambas as modalidades de escolas as crianças poderiam ter acesso aos mesmos conhecimentos. As escolas reunidas, por sua vez, em virtude da ausência de programas específicos para elas, eram obrigadas a seguir aqueles dirigidos também aos grupos, fossem eles o de 1905, o de 1921 e o de 1926, com a ressalva de que, nesse ano, a duração do curso das escolas reunidas era menor e, logo, seu programa devia ser menos desenvolvido. Em 1929, não obstante, foi determinado às escolas reunidas rurais e às escolas reunidas urbanas que aplicassem o programa das escolas isoladas rurais e o das escolas isoladas urbanas, respectivamente. As escolas reunidas sofreram, pois, em decorrência de seu caráter intermediário entre as escolas isoladas e os grupos escolares, a ambigüidade no que dizia respeito aos programas de ensino, ora devendo executar aqueles destinados a um tipo de escola, ora a outro. No tocante às escolas isoladas, restava a elas, quando ainda eram denominadas de escolas preliminares, tomar como base os programas de ensino de ensino das outras escolas primárias, como o de 1894 e o de 1904. A partir da década de 1910, com a tendência cada vez maior de se diferenciar os programas, a redução naqueles disponibilizados a elas e na duração do seu curso, traduzia as baixas aspirações do Estado em relação a esse tipo de escola primária. Já para as escolas-modelo isoladas, não foram elaborados programas de ensino, mas sim um horário-modelo, o qual foi inspirado o programa de 1911 das escolas isoladas.

\footnotetext{
${ }^{84}$ Ver Ribeiro (1996).
} 


\subsection{As finalidades dos programas de ensino oficiais}

Se os programas de ensino consistem na chave para se desvendar o papel atribuído pelo Estado à escola, não é menos importante o fato de que o processo de elaboração desses projetos culturais devia ser precedido pela reflexão em torno do seguinte questionamento: “Em qual modelo de ser humano desejamos que as crianças se tornem?”. Assim, a análise dos programas de ensino publicados entre 1887 e 1929 revela que os responsáveis pela construção do sistema público primário paulista - como bem resumia Benedito Tolosa - pretendiam "fazer de cada menino um cidadão integralmente educado" (A escola e seu papel educativo. In: Revista de Ensino, março de 1912, p.32). A proposta de uma formação integral, ou seja, do desenvolvimento intelectual, moral e físico da criança, foi formulada e disseminada a partir da obra do filósofo inglês Herbert Spencer, intitulada Educação intelectual, moral e física (1861). Empenhado em determinar quais os conhecimentos de maior valor para serem ministrados nas escolas, ele concluiu que só havia uma resposta possível para essa questão: a Ciência. Nas palavras do autor, ela é

(...) o vereditum para todas as interrogações. Para a direta conservação propria, para a conservação da vida e da saude, o conhecimento mais importante é a Ciencia. Para a indireta conservação propria, o que se chama ganhar a vida, o conhecimento de maior valor é a Ciencia. Para o justo desempenho das funções de familia o guia mais proprio só se encontra na - Ciencia. Para a interpretação da vida nacional, no passado e no presente, sem a qual o cidadão não pode justamente regularizar o seu procedimento, a chave indispensavel é a Ciencia. Para a produção mais perfeita e para os gozos da arte em todas as suas fórmas, a preparação imprescindivel é ainda a Ciencia, e para os fins da disciplina intelectual, moral e religiosa - o estudo mais eficaz é, ainda uma vez, a Ciencia (Spencer, p.77-78) ${ }^{85}$.

À época da escrita do livro, na Inglaterra, assim como em outros países europeus, o capitalismo industrial crescia rapidamente, impulsionado pelo avanço da ciência e da tecnologia, o qual culminou, pouco tempo depois, na Revolução Científico-Tecnológica. Pensando nisso, Spencer defendeu a imprescindibilidade da escola primária em contribuir com a expansão econômica, isto é, ela devia preparar os futuros trabalhadores para a sociedade industrial (Hobsbawm, 1982; Sevcenko, 2006; Souza, 2008). Para tanto, a Ciência era o conhecimento mais útil, em qualquer um de seus ramos, fosse ele a Matemática, a Mecânica, a Química, a Astronomia, a Geologia, a Biologia ou a Ciência da Sociedade. Ela

\footnotetext{
${ }^{85}$ No exemplar do livro consultado, não foi possível localizar o ano de edição.
} 
era considerada por Spencer, em suma, como sendo de extrema relevância para todos aqueles que se ocupariam com a produção, a troca ou a distribuição de produtos.

Não bastaria, contudo, que a escola capacitasse as crianças a enfrentar as mudanças no mundo do trabalho: além de investir no seu intelecto, era crucial também educá-las moral e fisicamente. No primeiro caso, tratava-se não apenas de assegurar a estabilidade da ordem pública, ameaçada pela pobreza e pela possibilidade de organização das classes operárias, como ainda de ensinar as camadas populares a governar uma família (Spencer, s/d; Souza, 2008). Avaliando como inadequada a educação moral dada pelos pais, o autor sugeria uma outra, fundamentada não em castigos, em ameaças e na violência física, mas sim em deixar os filhos sofrerem as conseqüências naturais das suas más ações. À guisa de ilustração, quando uma "criança cai, ou fére a cabeça contra uma mesa, sofre uma dôr, cuja lembrança a faz ser mais cautelosa; e pela repetição de tais experiencias vai-se oportunamente disciplinando na ordem dos seus movimentos” (Spencer, s/d, p.156). Quanto à educação física, Spencer verificava, de um lado, que os pais despendiam mais o seu tempo na criação de animais do que nos cuidados com a alimentação, o vestuário e os exercícios dos filhos, tarefas essas delegadas às mães. De outro lado, ele observava os danos que o excesso de trabalho mental poderia ocasionar, tais como graves doenças. Por isso, era preciso que as escolas incutissem nos futuros chefes de família a importância da constituição física, deixando transparecer, porém, sua preferência pelos jogos espontâneos em detrimento da ginástica.

No Brasil, a repercussão das idéias de Spencer, condensadas sob o termo evolucionismo social, foi notável. Além dos Pareceres de Ruy Barbosa, sua influência pode ser apreciada no Decreto n. 218, de 27 de novembro de 1893, que, ao se referir aos professores das escolas preliminares, definia que o "fim principal de suas funcções é educar physica, moral e intellectualmente os alumnos que se matricularem nas escholas a seu cargo, de accôrdo com o programma do curso preliminar" (Artigo 131). Também nos textos dos periódicos educacionais, em especial da Revista de Ensino, as menções ao filósofo eram constantes, implícita ou explicitamente (seu nome era citado). Romão Puiggari, por exemplo, confirmava que o "ensino primario (...) deve ser educativo, isto é, procurar o desenvolvimento sob os tres pontos de vista: physico, intellectual e moral" (A questão dos programmas. In: abril de 1902, n. 01, ano I, p.16). Por sua vez, o texto Ensino integral ${ }^{86}$ dirigia-se aos opositores da educação integral:

\footnotetext{
${ }^{86}$ Não há identificação do autor.
} 
Proporcionar ao povo mais do que o archaico e estafado saber lêr, escrever e contar, causa espanto aos nossos estadistas de longo folego, acostumados a mudar os nomes das instituições sem ousar alterar-lhes a substancia, quando não tentam fazelas retrogradar.

Aterra-os a idéa de um alfaiate, um marceneiro ou um typographo ter conhecimentos de physica, de chimica, de historia natural, de historia geral, de direito, etc.

Evidentemente um absurdo que só poderia nascer em cabeças de malucos como Spencer e Comte.

Em paizes onde a Republica não é uma simples abstracção, os estadistas não pensam desse modo, não temem o povo instruído (junho de 1905, n. 02, ano IV, p.644).

Além disso, João Lourenço Rodrigues salientava que, sendo a escola um

(...) instrumento da civilização e devendo, como tal, acompanhar pari-passu a sua evolução, já não póde fazer consistir a educação individual no desenvolvimento das forças physicas e na simples cultura dos sentimentos patrioticos.

Sem nunca perder de vista o destino futuro do individuo, ella é obrigada a promover o desenvolvimento integral e harmonico de todas as faculdades humanas. Ella terá, pois, de dirigir-se tanto ao corpo como ao espirito, e, tratando-se do espirito, não poderá deixar de votar cuidados especiaes a cada uma das suas faculdades (grifos meus; These $^{87}$. In: junho de 1902, n. 02, ano I, p.185-186).

Assim como Spencer, Rodrigues também entendia que a educação devia seguir as leis naturais da evolução social (Souza, 2000b, p.13). Desse modo, a formação completa do indivíduo era aquela mais condizente com uma sociedade que então se modernizava. Logo, era preciso renovar os programas de ensino das antigas escolas de primeiras letras. A Lei n. 81, de 06 de abril de 1887, representou o primeiro esforço nesse sentido, mas ela não podia prever o que estava por vir. Proclamada a República, a confiança nos poderes "iluminadores" da escola primária não apenas permaneceu, como ganhou contornos políticos de vulto: se até então ela era aquela que colocaria o país rumo ao progresso e à civilização, a partir desse momento sua responsabilidade passou a ser também transformar cada criança num novo cidadão. A convicção de Caetano de Campos de que a condição para a cidadania plena era um ensino enciclopédico, de base científica (Carvalho, 1989), levou os reformadores a estabelecerem um ensino primário de 8 anos de duração, dividido nos cursos preliminar e complementar. Essa determinação, trazida pela Lei n. 88, de 08 de setembro de 1892, foi reafirmada pela última vez no Regimento Interno das escolas públicas do Estado de São Paulo, de 1894. A Lei n. 374, de 03 de setembro de 1895, ao permitir que os alunos habilitados no curso preliminar se tornassem professores preliminares, impediu que os conhecimentos ensinados nele fossem aprofundados com a cultura geral oferecida pelo curso

\footnotetext{
${ }^{87}$ A tese desenvolvida pelo autor é: "Não podendo a escola completar a educação do homem no sentido amplo da palavra, quaes as condições que tem de preencher para que a sua influencia continúe a dirigir-lhe a educação na vida pratica?” (Revista de Ensino, junho de 1902, n. 02, ano I, p.184).
} 
complementar (Reis Filho, 1995). O ambicioso projeto republicano em relação à escola, assim, aos poucos ia desmantelando-se. Apesar disso, de 1892 até 1929, o conjunto de matérias incluídas nos programas do ensino primário pouco foi modificado, ao menos no que tange às escolas-modelo e aos grupos escolares.

Mas, além de Herbert Spencer, no que se basearam os reformadores para a produção dos primeiros programas de ensino? Aludindo ao programa de 1893 das escolas preliminares, o mesmo vigente a partir de 1892, o inspetor escolar Francisco Pedro do Canto, em relatório datado de 1900, asseverava: "É um programma vasto, bem dilineado e modelado pelo dos paizes mais adiantados do mundo" (Ordem 7025). De fato, foram selecionadas matérias que, em todo o Ocidente, estavam sendo consideradas como indispensáveis para a modernização da cultura dirigida ao povo, particularmente a Ginástica, as Ciências, o Desenho, o Canto e a Música_(Souza, 2008). Se, como visto no Capítulo 1, as capitais da Europa, notadamente Paris e Londres, eram as referências das elites paulistas no que dizia respeito, por exemplo, à arquitetura, ao vestuário, à literatura, aos esportes e aos ritos de sociabilidade, era natural que isso também se estendesse à educação. Ademais, a inspiração, tanto em programas de ensino organizados no exterior, quanto em Spencer, demonstrava claramente que se tinha em vista um único desejo. Isso porque, como escreve Schwarcz (1995, p.34), “o conhecimento e a aceitação desses modelos evolucionistas e darwinistas sociais por parte das elites intelectuais e políticas brasileiras traziam a sensação de proximidade com o mundo europeu e de confiança na inevitabilidade do progresso e da civilização”.

Embora, nos limites do presente trabalho, não seja possível reconstruir a história de todas as matérias que compunham os programas de ensino, cumpre aqui examinar as funções de algumas delas. A Leitura, a Escrita (denominada Linguagem escrita nos programas publicados entre 1904 e 1926) e a Aritmética em nenhum momento saíram dos programas de ensino, independentemente do tipo de escola primária. Por meio dos programas que detalhavam os conteúdos, é possível perceber que o objetivo principal da Leitura era ensinar a criança a ler corretamente, ou seja, com naturalidade, expressividade e sem erros de pronúncia. Valorizava-se, dessa forma, a leitura em voz alta, o que demonstrava que a oralidade ainda era uma característica forte da sociedade brasileira (Souza, 2008). O ensino dessa matéria compreendia, por exemplo, reconhecer e pronunciar os sons das letras em 
palavras de uma sílaba; recitar, em coro, pequenas poesias; decorar pequenos versos; conhecer os sinais de pontuação; ler pequenos trechos de revistas e jornais; utilizar livros de leitura adequados à idade e ao desenvolvimento do aluno; ler versos, diálogos e biografias de brasileiros ilustres (1905 - escolas-modelo; grupos escolares) ${ }^{88}$; "leitura, comentada pelo professor, de excerptos escolhidos, proprios a despertarem nos alumnos o gosto e o amor pelo bello" (1911 - escolas isoladas); ler lições da cartilha (1918 - escolas isoladas rurais, distritais e urbanas; grupos escolares).

Fortemente atrelada à Leitura, estava a Linguagem oral. Complemento da primeira, os conteúdos dessa matéria contribuíam para realçar a especificidade dos diferentes programas de ensino, dado que muitas das prescrições aproveitavam temas relacionados ao meio em que se localizava a escola. O ensino abrangia, entre outros tópicos, narrações simples de fatos instrutivos e morais (1905 - escolas-modelo; grupos escolares); palestras com os alunos sobre coisas ou cenas de fácil observação, relativas ao lar, à rua, à escola e ao campo e descrição de objetos usuais e de animais domésticos (1911 - escolas isoladas); palestras sobre a utilidade dos animais, sobre a cultura de cereais, de hortaliças, de forragens, de cana de açúcar e de café, e sobre a criação de aves e de gado, grande e pequeno (1913 - escolas de bairro); nomes e qualidades de animais domésticos e selvagens, plantas, frutos, árvores frutíferas (1918 escolas isoladas rurais, distritais e urbanas); recitação, com explicação prévia, de máximas e pequenas poesias apropriadas à idade e ao desenvolvimento mental da classe (1918 - grupos escolares); trechos de educação moral, de civilidade, para recitação (1921 - escolas isoladas, escolas reunidas e grupos escolares).

A Linguagem oral, por sua vez, era indissociável da Linguagem escrita. A finalidade da matéria era ensinar a criança a registrar, por escrito, a expressão do pensamento, aprendida na primeira (Esteves, 2002). No rol de conteúdos estavam: fáceis e pequenas composições; ditado; cartas, ofícios, requerimentos e recibos (1905 - escolas-modelo; grupos escolares); copiar nomes de objetos, animais, flores e frutas (1911 - escolas isoladas); emprego dos sinais de pontuação (1918 - escolas isoladas rurais, distritais e urbanas); esboço biográfico de brasileiros ilustres (1905 e 1918 - grupos escolares); copiar trechos de civilidade, máximas, trechos de civismo (1921 - escolas isoladas, escolas reunidas e grupos escolares). Também relacionada com a Leitura, a Linguagem oral e a Linguagem escrita, a Caligrafia serviria para a criança aprender o movimento de escrever (Esteves, 2002). Para isso, ela devia copiar letras,

\footnotetext{
${ }^{88}$ Os parênteses são utilizados quando os conteúdos são exclusivos de determinados tipos de escolas. A ausência deles indica, assim, que os conteúdos foram retirados dos programas de 1894 e de 1904, quando os mesmos ainda não eram diferenciados.
} 
palavras, algarismos e sentenças escritas pelo professor no quadro-negro. No programa de ensino das escolas isoladas de 1911, são dadas orientações sobre o ensino dessa matéria: "a escola primária não pretende dar ao alumno a technica impeccavel no traçado de lettras, de modo a tornar-se elle um calligrapho perito, mas sim fornecer-lhe a calligraphia como um instrumento que o habilite a manifestar, por escripto, com rapidez e clareza, os seus pensamentos".

Por fim, a meta da Aritmética era oferecer à criança conhecimentos de aplicação prática, especialmente para aquela que levava uma vida urbana e/ou futuramente iria se inserir num mercado de trabalho no qual aumentavam as oportunidades no setor financeiro, comercial e industrial, como era o caso da Capital. Assim, com o auxílio de objetos como tornos, tábuas, contador mecânico e grãos de milho (nas escolas isoladas), o professor devia ensinar ao aluno conteúdos como: contar; as quatro operações (somar, subtrair, multiplicar e dividir); tabuada; frações ordinárias e decimais; resolução de problemas; ler e escrever os números compostos; exercícios práticos sobre as medidas nas lojas, armazéns e bancos; redação de cartas comerciais, memorandos e faturas. Ao lado da Aritmética, a Geometria formava a parte "matemática" dos programas de ensino. Ausente no programa de ensino das escolas isoladas de 1911 e naquele das escolas de bairro de 1913, o ensino da matéria envolvia, por exemplo, o ponto, a linha, a superfície, os sólidos e as esferas. Antonio Pena compara essa matéria com o Desenho:

\footnotetext{
Uma das materias mais interessantes do nosso programma de ensino é certamente a geometria.

(...) O tempo consagrado ao estudo da geometria, além de interessar devéras aos alumnos, é ainda um poderoso auxiliar, não só para o estudo do desenho, base de similhante estudo, como tambem muito concorre para auxiliar o desenvolvimento do raciocinio das creanças (Geometria. In: Revista de Ensino, agosto de 1902, n. 03, ano I, p.411).
}

Excluído também do programa de 1913, o Desenho não devia ser ensinado "como arte, mas como uma linguagem viva que sirva para desenvolver nas creanças a imaginação, a observação e o gosto esthetico" (escolas isoladas - 1911). Entre os conteúdos da matéria estavam o desenho de figuras geométricas, de flores, de animais e de objetos usuais, bem como a cópia de modelos e de pequenas paisagens. A utilidade do Desenho foi defendida por Raul Pederneiras:

Partidarios do ensino do desenho nos estudos primarios (...), achamos que deve ser obrigatorio (...). Não saber desenhar, na accepção simples do termo, é como não saber escrever. Educando a attenção, favorecendo as comparações das linhas nos modelos, animando o espirito de observação, encorajando o temperamento que se 
revela, teremos dado um acervo de educação artistica que se multiplica em resultados esplendidos.

(...) a obrigatoriedade do desenho deve ter preferencia entre muitas outras disciplinas, taes como o francez ou qualquer outro idioma, vivo ou morto; não com o fim de fazer artistas, porque estes já nascem feitos, mas com o fito de aperfeiçoar a educação, estimulando as vocações futuras (grifos meus; $\underline{\mathrm{O} \text { desenho obrigatorio. In: }}$ Educação, outubro de 1927, n. 01, ano I, p.108).

O intuito dos Trabalhos manuais também era o de aproximar a criança do universo do trabalho, mas sem a preocupação de lhe ensinar um ofício específico (Souza, 2008). Com efeito, Manoel Penna argumentava que a matéria devia ser tratada

(...) como um meio educativo que dá ás crianças uma destreza geral das mãos e principios de alguns officios, de modo a tornal-as aptas para a vida, isto é, em condições de se especializarem mais facilmente em qualquer profissão que mais tarde fôr escolhida, pois as operações basicas são mais ou menos communs em todos os officios; o que varia é a materia prima (Ensino technico na escola primaria. In: Educação, abril de 1928, n. 01, ano III, p.107-108).

O ensino dos Trabalhos manuais, ao mesmo tempo, serviria para combater o preconceito em relação ao trabalho manual, ainda persistente numa sociedade pós-escravista (Souza, 2008). Além disso, o inspetor escolar Aristides de Macedo exaltava a importância da matéria na educação moral da criança: "O alto valor educativo dos trabalhos manuaes, nas escolas, resulta, pois, do seu poderoso concurso á formação do caracter, estimulando as forças da intelligencia e incitando as qualidades moraes" (Anuários do Ensino de 1913, p.XLVIIXLIX).

Presente em todos os programas de ensino publicados no decorrer do período, os conteúdos escolhidos para os Trabalhos manuais refletiam a rígida divisão de papéis sociais entre mulheres e homens. Embora ambos devessem aprender a dobrar papel, para a montagem de objetos como chapéus e caixas, somente os meninos poderiam realizar atividades de carpintaria (esquadros, réguas bancos, mesas) e de modelagem em argila (figuras e objetos). Por outro lado, eram exclusivos das meninas a costura simples (pregar, cozer, franzir, remendar) e o crochê. Curiosamente, no programa de ensino das escolas isoladas de 1911 e naquele das escolas de bairro de 1913, a matéria era prescrita apenas para o sexo feminino. Importa sublinhar ainda que, nos quatro programas de ensino anexados no Decreto n. 2944, de 08 de agosto de 1918, passaram a ser incluídos novos conteúdos, mais ligados à vida no campo, como: trabalhos práticos de horticultura, arboricultura e jardinagem (todos os tipos de escolas primárias) e feitura de utensílios simples e necessários a esses trabalhos, com o material encontrado nas vizinhanças da escola (escolas isoladas rurais e distritais); aplicação 
manual de folhas, de fibras lenhosas, de vime, de cipó, de couro, de pêlos e penas (escolas isoladas distritais e urbanas; grupos escolares).

No que concerne à Ginástica, seu objetivo, esclarecia M. Baragiola, não era "formar acrobatas, ou artistas de circo: ella foi introduzida nas escolas para desenvolver e fortalecer o organismo, em proveito do espirito e da vida pratica (Gymnastica Moderna. In: Revista de Ensino, junho de 1902, n. 02, ano I, p.256). Por outro lado, ela também devia propiciar a elevação moral da criança, como compreendia Eurigenes Lessa:

(...) a educação physica póde e deve proporcionar uma certa educação moral e social, que tanto mais util e profunda será quanto mais tenra fôr a edade dos alumnos. (...) Uma orientação intelligente fará do esporte uma escola esplendida de caracter. Os jógos de conjunto têm nesse ponto importante papel. Ensinam a cooperação, a necessidade de apoio mutuo, o sacrificio em prol da collectividade, e, num povo individualista como o brasileiro, o 'foot-ball', a bola ao cesto e o 'volleyball', quando bem disseminados e quando superiormente dirigidos, estão destinados a exercer uma profunda influencia na vida da nacionalidade (grifos meus; $\underline{A}$ finalidade da educação physica. In: Revista Escolar, março de 1927, n. 27, ano III, p.02-03).

Ausente do programa de ensino de 1913 (escolas de bairro), o ensino da matéria envolvia conteúdos que se diferenciavam conforme o gênero. Para ambos os sexos, eram prescritos, por exemplo, exercícios calistênicos ${ }^{89}$ - que deviam ser realizados de preferência com as alunas, conforme o Artigo 52 do Decreto n. 1216, de 27 de abril de 1904 -, marchas, corridas, jogos e brinquedos ao ar livre. Restritos aos meninos, estavam pulos e passos rítmicos. Na Escola-Modelo "Caetano de Campos", Jorge Americano relembra que havia "aula de ginástica sueca no pátio de recreio, com bastões, marchas, corridas, saltos de trampolim, subida de corda, pulos de cavaletes, exercício de paralelas e barra fixa” (2004, p.30).

Do programa de ensino das escolas preliminares de 1892 até aquele de 1905, destinado às escolas-modelo e aos grupos escolares, a Ginástica estava vinculada a uma outra matéria, a saber, os Exercícios militares. Dirigida somente aos meninos, o ensino dela levou à formação dos chamados batalhões infantis que, treinados fora do horário regular das aulas, reproduziam a organização das corporações militares. No período da Primeira Guerra Mundial, a prática dos Exercícios militares entrou em declínio, engendrado por críticas, vindas mesmo de outros países, sobre a obrigatoriedade do ensino ou preparo de caráter militar antes dos 19 anos

\footnotetext{
${ }^{89}$ Os exercícios calistênicos originaram-se da Ginástica sueca e buscavam promover a beleza e a força corporal (Vago, 2002).
} 
(Souza, 2000c). O artigo intitulado A Educação Militar apresenta as razões para a inserção da matéria nos programas de ensino:

(...) a preoccupação do legislador, não em educar a força armada, mas sim em dar ao povo a educação militar, sobre ser obra do mais acrysolado patriotismo, é o único meio de construir para o Brasil, paiz apenas sahido do estado embryonario, um arcabouço indestructivel, em cujas malhas se virão formar, por selecção espontanea, livre e natural as aggremiações estaduaes, pujantes de seiva, de vitalidade e de progresso, guiados todos os impulsos nobres de seus homens pelo sentimento civico da Patria una, engrandecida e respeitada (Revista de Ensino, junho de 1904, n. 02, ano III, p.93).

Excluído do programa de ensino de 1913 (escolas de bairro), o ensino do Canto e/ou da Música englobava conteúdos tais como: cantos por audição, solfejos, exercícios de vocalização; "cantos de hynos e canções brasileiras com o fim de despertar sentimentos civicos e patrioticos" (escolas isoladas urbanas - 1918); ginástica respiratória (grupos escolares - 1918). As funções da Música, como pontua Morila (2006), eram várias. Uma delas era a higiene, ou seja, o desenvolvimento e a saúde dos órgãos da audição e da respiração. Ademais, ela poderia ser utilizada como espetáculo escolar, isto é, a partir de apresentações musicais em festas escolares ${ }^{90}$, especialmente de hinos pátrios, seriam disseminados os valores republicanos para toda a sociedade. Somava-se a isso a educação estético-moral, o que significava, de um lado, despertar os sentidos da criança, como ilustram as seguintes observações contidas no programa de ensino das escolas isoladas de 1911: “As letras dos hymnos patrios devem ser cuidadosamente explicadas pelo professor aos alumnos, de modo que, comprehendendo, sintam devéras o que cantam”. De outro lado, tratava-se da dulcificação dos costumes, como frisava Silva Monteiro:

A musica não deve sêr encarada como simples passatempo ou prenda de menina mais ou menos habilidosa; a sua missão é mais séria, mais amplo o seu campo de utilidade; a par das outras artes chamadas plasticas, deve acompanhar a vida dos povos, embellezando-a, espiritualizando-a, para tornar mais ductil ás emoções superiores, que fazem o homem bom e util á communidade (Os orpheões escolares. In: Revista Escolar, setembro de 1926, n. 21, ano II, p.10).

Além da Matemática, outros conhecimentos científicos deviam ser apresentados às crianças. Os responsáveis pela criação dos programas de ensino, nesse sentido, acolheram a idéia de Herbert Spencer", retomada por Luiz Cardoso, de que "é na sciencia em sua accepção

\footnotetext{
${ }^{90}$ Ver Cândido (2007).

${ }^{91} \mathrm{O}$ entusiasmo pela ciência também contagiou o positivismo. Essa doutrina filosófica do francês Augusto Comte atraiu particularmente os militares brasileiros, mas também intelectuais como Rui Barbosa. Outros pontos de defesa do positivismo eram a ditadura republicana, a separação da Igreja e do Estado e a incorporação do proletariado na sociedade (Carvalho, J., 2007; Fausto, 2007). Apesar disso, foi o evolucionismo social a corrente
} 
mais lata que se funda a realização dos progressos, que tornam possivel a vida civilizada" (Educação analytica. In: Revista de Ensino, junho de 1912, n. 01, ano XI, p.31). As Ciências físicas, químicas e naturais ganharam um grande espaço no programa de ensino das escolas preliminares de 1894, a ponto desse ter sido alvo de críticas de Ramon Roca Dordal: "Não trataremos de discutir ou indicar as condições a que o nosso programma de ensino publico primario precisa obedecer (...). Hoje falaremos unicamente de uma das partes da questão, isto é, do estudo de sciencias, estudo incluido agora no programma preliminar com os nomes pretenciosos de: physica-chimica-zoologia-botanica-geologia" (Um assumpto de actualidade. In: Revista de Ensino, outubro de 1902, n. 04, ano I, p.588). O autor referia-se aos conteúdos da matéria, classificados nas especialidades acima e que prescreviam, por exemplo, para a Física e a Química: experiências curiosas e fáceis, peso e densidade dos corpos, cores, gravidade, pressão atmosférica. Para a Zoologia: partes do corpo humano, animais (aves, peixes, répteis, anfíbios), tratamento dos dentes, limpeza da cabeça e do corpo, cuidado do vestuário. Para a Botânica: partes da planta e da flor, vegetais (comestíveis, medicinais, perigosos), conselhos higiênicos sobre a inconveniência de se comerem os frutos verdes. Para a Mineralogia: grau e dureza das rochas, pedras preciosas (cristais, diamantes). Para a Geologia: formação da crosta terrestre, movimentos do solo, calor central e transformação da superfície da terra. Embora a Física, a Química, a Zoologia e a Botânica devessem ser ensinadas em todas as 8 séries, a Mineralogia foi inserida na $1^{\mathrm{a}}$. série do $3^{\mathrm{o}}$. ano e substituída pela Geologia na $2^{\mathrm{a}}$. série do $4^{\mathrm{o}}$. ano.

No programa de ensino de 1904 (escolas-modelo, grupos escolares e escolas isoladas), como forma de se rebater as críticas à extensão dos conteúdos do programa anterior, reduzidos a partir de então, os professores foram orientados a levar em conta que o ensino das Ciências Físicas e Naturais "tem por fim mais ensinar a observar, a experimentar, a classificar do que propriamente o ensino das matérias que compõem o programma, isto é, é essencialmente educativo". No programa de ensino das escolas isoladas de 1911, a recomendação foi repetida: "esta parte do programma visa educar a observação dos alumnos e não lhes ministrar conhecimentos estereis de zoologia, com classificações, nomenclaturas, etc, que nenhum valor têm”. Assim, no ensino da matéria, como sugeria Augusto de Carvalho, cabia ao professor aproveitar "o mais possivel as licções de coisas para dar aos alumnos as noções mais essenciaes da sciencia" (O actual programma de ensino dos grupos e da escola-modelo I. In:

Revista de Ensino, junho de 1909, n. 02, ano VIII, p.05). A articulação das Ciências com as

de pensamento que, além do liberalismo, teve efeito mais duradouro no Brasil, já que reunia as mesmas "vantagens do positivismo, sem os seus inconvenientes" (Barros, 1959, p.146). 
"lições de coisas" era tamanha que, no programa de ensino de 1913 (escolas de bairro), a primeira é denominada de Noções de coisas. As "lições de coisas" compreendiam a fase inicial do método intuitivo, na qual a criança teria a oportunidade de observar, ver e manusear objetos. Por isso, o professor era solicitado a organizar, com o auxílio dos alunos, pequenos museus escolares, cujos objetos seriam coletados a partir de passeios de estudos ou então trazidos de casa por eles (Faria Filho, 2000; Souza, 2008).

Ainda no tocante às noções científicas, os programas de ensino determinavam que se devia demonstrar as aplicações práticas das mesmas, especialmente na higiene. Se, na Capital, a construção de vilas operárias, a elaboração da legislação urbana e a visita aos domicílios não foram suficientes para contornar os problemas de saúde pública, especialmente as epidemias, a escola aparecia, aos olhos dos higienistas sociais, como um recurso altamente eficaz. Afinal, os preceitos higiênicos ensinados não deveriam ficar restritos à esfera escolar, mas seriam, por intermédio da criança, reproduzidos nas famílias, e, por fim, na sociedade em geral. Foi, com efeito, desqualificando as formas populares do cuidado com a saúde que a Higiene - ramo da ciência dedicado, sobretudo, à medicina do social - legitimou sua interferência no campo educacional (Gondra, 2000):

\footnotetext{
Vulgarizar os preceitos da hygiene entre a collectividade humana que os prejulga com desdem e com desagrado, quando não se encastella nos seus viciosos habitos - é difficil tarefa, até ás vezes impossivel.

Devemos, por isto mesmo, emprehender esta vulgarização na escola, preparar a criança, dotando-a com um arsenal completo de conhecimentos praticos, de costumes bons e puros, de regimen severo na vida, para a lucta que, em defeza de sua saude, ha de manter contra innumeraveis elementos exteriores que o combatem e hão de combatel-o até a morte (Azurdia, José. A hygiene nas escolas. In: Revista de Ensino, dezembro de 1911, n. 03, ano X, p.43).
}

Entre os conteúdos previstos estavam: higiene da alimentação, do vestuário e da habitação; o exercício e a higiene corporal; cuidados para evitar as moléstias contagiosas; primeiros socorros médicos nos casos urgentes; o abuso do fumo e do álcool. Nos programas de ensino de 1918 (escolas isoladas rurais, distritais e urbanas; grupos escolares), foram acrescentadas outras prescrições, como, por exemplo, insetos transmissores de moléstias; vacinação contra a varíola e contra a febre tifóide; moléstias contagiosas e infecciosas: impaludismo, ancilostomose, tuberculose, lepra, tracoma e raiva; meios de evitar e tratar.

Além da higiene, a utilidade das ciências na agricultura e na indústria, bem como o avanço científico-tecnológico, também faziam parte dos programas: 
- apicultura e sericultura; fabrico de manteiga e do queijo; "A raiva. Como se procedia antigamente e como se procede hoje em seu tratamento. Pasteur (...). A illuminação: a lareira, as tochas, o azeite, o kerozene, o gaz e a luz electrica" (escolas isoladas - 1911);

- as culturas próprias da zona em que está a escola e criação de animais úteis (escolas de bairro - 1913; escolas isoladas rurais - 1918);

- estudo intuitivo dos minerais ao alcance do aluno: propriedade, emprego, valor, onde são encontrados e meios de sua preparação para as indústrias (escolas isoladas distritais 1918);

- "Explicação concreta da campainha electrica, do telephone, do telegrapho, do pararaios, do pendulo do relogio, de alavancas e balanças, roldanas, planos inclinados, luz e força electrica, circulação do ar, aquecimento do ar, illuminação a gaz, tensão do vapor da agua, acção corrosiva dos acidos e dos alcalis, poder dissolvente do alcool e da essência de therebentina, etc., applicações do vapor e da eletricidade (...). Plantio e cultura de arvores frutiferas e mais vegetaes uteis e proprios do nosso clima. Epoca do plantio e processos de cultura. Epoca e processo de poda. Adubos" (grupos escolares - 1918).

A História do Brasil e a Geografia completavam a face científica dos programas de ensino. Na primeira, tratava-se do ensino de noções gerais sobre fatos que iam desde a descoberta do Brasil até os dias atuais, como ilustram os conteúdos seguintes: o descobrimento; os colonos e os indígenas; Caramuru; primeiros povoadores; primeiros governadores; invasões estrangeiras; bandeirantes; emboabas; Tiradentes; mudança da família real para o Brasil; Independência; Guerra do Paraguai; propaganda e proclamação da República; palestras sobre as riquezas, belezas naturais e recursos de nosso país, de modo a despertar na criança sentimentos de entusiasmo pela Pátria (escolas isoladas rurais, distritais e urbanas; grupos escolares - 1918); notícia biográfica dos brasileiros ilustres que tomaram parte nos seguintes acontecimentos: proclamação da República. Império sob o reinado de D. Pedro II e de D. Pedro I. Independência. Mudança da família real portuguesa para o Brasil. Período colonial. Descobrimento. Indígenas (escolas-modelo; grupos escolares - 1905).

O que se visava com essa matéria era apresentar à criança um passado único, fruto de uma nação coesa, construída com a contribuição, ou seja, com o trabalho produtivo de personagens considerados heróis e os quais deviam servir de exemplos para ela (Bittencourt, 1990). Isso fica explícito nas observações inseridas no programa de ensino das escolas isoladas de 1911: “O programma contém apenas os grandes factos de nossa historia, de preferencia aquelles que mais directamente têm cooperado para a civilização nacional. São 
quadros syntheticos do trabalho actual e das gerações passadas para o engrandecimento do Brazil. É sob tal aspecto que serão contados aos alumnos esses factos, de modo que falem á sua imaginação e lhes inculquem o dever civico do trabalho collectivo. (...) Estudando-se um grande facto, pôr-se á em destaque o grande vulto que o personifica. (...) Procurando-se despertar no alumno o sentimento de fraternidade universal, não se deve ir ao exagero de calar os nomes e os rasgos de heroismos dos que se bateram, no momento necessario em defesa da Patria".

Já os conteúdos da Geografia traduziam claramente os princípios do método intuitivo, uma vez que eles partiam do que era conhecido da criança para se chegar ao que ela desconhecia, isto é, do "estudo local até o estudo astronômico", conforme o programa de 1904. Assim, a própria sala de aula seria o cenário para o professor ministrar as primeiras noções de orientação (direita, esquerda, superior, inferior, frente, atrás). Na seqüência, havia tópicos tais como: nomes das ruas, medidas do tempo, as estações, pontos cardeais, a cidade de São Paulo, o Brasil, principais países da América e da Europa, e idéia geral sobre o sistema planetário. Intimamente relacionada com a História do Brasil, a finalidade dessa matéria foi abordada por Benedicto Galvão:

\footnotetext{
Encarada, ao mesmo tempo, pelo lado industrial, commercial e economico, extraordinariamente consideravel é a importancia dos conhecimentos geographicos; basta lembrar que se aproveitam as quedas de agua, para mover as machinas; que, para o abastecimento das cidades, se procuram as aguas, que derivam de regiões elevadas; que a navegação fluvial dispensa as estradas de ferro; e que, finalmente, uma boa carta das costas dos paizes e das entradas dos portos evita desastres.

Voltando, agora, os olhos para a importancia dos conhecimentos de geographia, nas occasiões de guerra, ahi está a Historia para proclama-los (Cartographia. In: Revista de Ensino, agosto de 1902, n. 03, ano I, p.496).
}

Para finalizar, a formação do caráter da criança e fazê-la conhecer os direitos e os deveres do cidadão eram os propósitos principais da Instrução moral e física, ausente do programa de ensino das escolas isoladas de 1911. Entre suas prescrições estavam, por exemplo, conversações familiares, visando à formação dos bons sentimentos entre as crianças; corrigir suas faltas, sempre que elas se derem; hábitos de ordem e de comportamento na escola, em casa, na rua e em lugares públicos; deveres para com os pais e superiores, iguais e inferiores; tratar com bondade os animais; máximas que desenvolvam boas qualidades; insistir sobre o respeito à rua e especialmente contra as inscrições inconvenientes nas paredes, nos muros, nos móveis (escolas isoladas distritais e urbanas; grupos escolares - 1918); deveres para consigo mesmo, família, escola, sociedade; deveres para com a Pátria em geral; exemplos de amor à Pátria; impossibilidade de uma sociedade sem governo e demonstração 
desta verdade por meio de exemplos fáceis; princípios gerais, demonstrando as vantagens da República; o voto, sua importância, sua responsabilidade; o direito e o dever de votar; o imposto, sua necessidade - sem imposto não pode haver governo; a Justiça; a polícia; mostrar a semelhança entre os castigos na escola e as penas na sociedade.

Como bem explica José Murilo de Carvalho (1990), o mesmo povo que foi mantido afastado do processo de implantação da República se tornou peça imprescindível para a legitimação do novo regime político. Isso porque, ao apoderar-se do imaginário popular, poderiam ser manipulados os sentimentos coletivos, de modo a conformá-los aos novos valores republicanos. A escola primária era um instrumento de extrema importância para tal tarefa, especialmente quando se considera que, no país, a sensação de que se pertencia a uma nação ainda inexistia. No ambiente escolar, símbolos, mitos, rituais e alegorias deveriam ser utilizados para "formar as almas" dos futuros cidadãos, tal como se concebia a educação na Revolução Francesa, ou seja, plasmar suas visões de mundo e modelar suas condutas. Era preciso, todavia, também irradiar o civismo republicano para toda a sociedade. Por isso, nas escolas primárias paulistas, foram organizadas festas cívicas para que ela pudesse participar, tais como a denominada "Festa da Bandeira", comemorada no mês de novembro (Cândido, 2007). Nas festas da Escola-Modelo "Caetano de Campos", segundo relato de Americano (2004, p.30), até mesmo as autoridades políticas assistiam a elas:

(...) Os meninos que desenhavam melhor incumbiam-se de paisagens, bandeiras, escudos e motivos alegóricos, a giz de cor, nos quadros-negros (...).

As festas consistiam em cantos patrióticos, ginástica de sala, recitativos e entregas de prêmios. Todos vinham de branco, com gravatas cor-de-rosa ou azuis, de acordo com a recomendação da professora (...).

$\mathrm{Na}$ festa do fim do ano esteve o Vice-Presidente Coronel Fernando Prestes. Recitei, engasguei no meio, a professora soprou, continuei. Ganhei uma medalha.

Como não poderia deixar de ser, a busca por uma identidade coletiva também norteou a elaboração dos programas de ensino. Correia (2000) sublinha que, no decorrer do século XIX, período de emergência dos Estados-Nações, a Leitura, a Escrita, a Aritmética, a História e a Geografia foram essenciais para a conquista da unidade política e cultural. Enquanto por meio das duas primeiras matérias se adquiria uma língua padrão, capaz de se sobrepor aos particularismos regionais, a aprendizagem da Aritmética fornecia um código nacional comum, por exemplo, para se comprar e vender, para o cálculo de impostos e para medir o tempo e as 
distâncias. Através da História e da Geografia, por sua vez, seriam construídos referenciais histórico-culturais e físico-geográficos, respectivamente. No Estado de São Paulo, a preocupação com a formação da nacionalidade era tamanha que, além da incorporação dessas matérias nas escolas públicas primárias, foi colocada em vigor a Lei n. 489, de 29 de dezembro de 1896: "Em todos os estabelecimentos e escolas particulares de instrucção primaria, para ambos os sexos, dirigidos por professores de qualquer nacionalidade, é obrigatorio o ensino da lingua nacional" (Artigo 1), o qual devia abranger a leitura, noções da gramática portuguesa, exercícios de ditado e composição (Artigo 2). Tratou-se, portanto, de uma iniciativa que almejava a nacionalização dos estrangeiros. Não à toa, o documento também determinava a obrigatoriedade do ensino da História do Brasil e da Geografia. Para que a Lei fosse regulamentada, E. Mario de Arantes, autor do texto intitulado Obrigatoriedade do ensino de lingua portugueza nos collegios particulares, pedia que a língua nacional fosse salva de um "cruzamento nefasto":

A população estrangeira cresce constantemente neste Estado, mórmente nesta Capital.

É sabido que ha ruas inteiras aqui, onde não se houve uma palavra de nossa lingua.

Ha aqui creanças, aqui nascidas, que recebem educação em escolas extrangeiras, falando a lingua de seus paes, aprendendo a historia e a geographia da patria delles, apenas sabendo que il Brasile é um paiz de exilio.

Estes jámais serão cidadãos brazileiros (In: Revista de Ensino, outubro de 1902, n. 04, ano I, p.583).

O temor de que a presença estrangeira pudesse comprometer a construção da nacionalidade brasileira também era manifestado por Augusto de Carvalho. Defensor engajado dos exercícios militares, como é possível notar nos artigos escritos por ele na Revista de Ensino, o autor não hesitava quando o tema era a relevância da educação cívica nas escolas:

\footnotetext{
Ser patriota é defender o paiz, em todas as emergencias, mesmo com o sacrificio dos deveres e da propria vida. E é preciso, é urgente que o sejamos: quando uma molestia ataca o organismo, vai-se apossando delle aos poucos e o levará ao tumullo. Pois nós estamos com a doença em casa: os extrangeiros têm escolas, em que não ensinam a nossa lingua, nem a nossa geographia e historia e mantêm imprensa em que pouco se preoccupam com os interesses nacionaes (Paginas civicas. In: Revista de Ensino, junho de 1903, n. 02, ano II, p.116).
}

Mas, na escola pública primária paulista, não bastava que o espírito patriótico perpassasse as matérias dos programas de ensino. As palavras de Caetano de Campos deixam claro que, para ele, como "a revolução entregou o povo a si mesmo, nada é mais urgente do que cultivar-lhe o espirito, dar-lhe a elevação moral de que elle precisa, formar-lhe o caracter, 
para que saiba querer" (In: Educação, julho de 1929, n. 01, vol. VIII, p.11). Romão Puiggari também concordava que, embora a educação integral propiciasse o desenvolvimento harmônico dos aspectos físico, intelectual e moral, "é o terceiro o mais importante. (...) A escola deve ser a modificadora dos defeitos da sociedade, do meio" (A questão dos programmas. In: Revista de Ensino, abril de 1902, n. 01, ano I, p.16). Além disso, na perspectiva de João Lourenço Rodrigues, a moral é "o departamento mais importante da educação individual, pois, como judiciosamente observa Herbert Spencer, mais vale uma mão cheia de boa moral do que um alqueire de instrução" (grifos do autor; These. In: Revista de Ensino, junho de 1902, n. 02, ano I, p.186). Incutir valores morais e cívicos na criança era, dessa forma, o empreendimento central ao qual se deviam lançar os programas de ensino. Logo, o desenvolvimento das faculdades intelectuais e físicas ficava subordinado ao destaque concedido ao papel moralizador e nacionalizador atribuído à escola. Isso elucida porque que se apregoava que a "missão do professor primario não é instruir, é educar", tal qual o faz Luiz Cardoso (Educação analytica. In: Revista de Ensino, junho de 1912, n. 01, ano XI, p.33). Dessa opinião também partilhava o inspetor escolar Julio Pinto Marcondes Pestana: “A escola publica primaria tem ainda, a despeito das melhores leis e regulamentos, a preoccupação de instruir; com o que, pretere a formação do caracter e o desenvolvimento do sentimento nacional" (Anuários do Ensino de 1910-1911, p.66).

Essa diferença entre instrução e educação era, por sua vez, a responsável pela ambigüidade presente nos programas do ensino primário. Se isso já era observável no programa de ensino de 1887, a passagem do Império para a República explicitou ainda mais que, para o Estado, a introdução de novas matérias na escola primária com vistas a modernizar a cultura oferecida ao povo, não poderia ser realizada sem se recorrer a outras, que assegurassem que o programa tivesse também um perfil conservador (Souza, 1997). É nesse sentido que - como ilustra a opinião do inspetor escolar Leopoldo Sant'anna - a "educação moral e civica, pela sua natureza e capital importancia, não devia figurar isoladamente, não devia occupar logar distincto, no programma e horario de nossas escolas, mas servir de base á integralidade do ensino" (Anuários do Ensino de 1913, p.LXXXIV).

Tal preceito não somente levou à escolha da Instrução moral e cívica, como ainda fez com que as demais matérias, tais como os Trabalhos manuais, a Ginástica e Exercícios militares, a Música, a Geografia e a História do Brasil, em maior ou menor medida, pudessem auxiliá-la. Além disso, ler versos, diálogos e biografias de brasileiros ilustres; narrar fatos instrutivos e morais, bem como copiar trechos de civilidade, máximas e trechos de 
civismo figuravam nos conteúdos prescritos, no decorrer do período, para a Leitura, a Linguagem oral e a Linguagem escrita, respectivamente. Somava-se a isso a criação do escotismo e do "Orfeão Infantil Paulista" que, formado por alunos, de ambos os sexos, do $3^{\circ}$. e do $4^{\circ}$. anos dos grupos escolares de todo o Estado, tinha como fim "desenvolver, por meio do canto, o gosto artistico pela poesia e pela musica nacional" (Decreto n. 4101, de 14 de dezembro de 1926). Já o escotismo apareceu pela primeira vez num programa de ensino em 1918, como parte dos conteúdos da Ginástica das escolas isoladas distritais e das escolas isoladas urbanas e retornou naquele publicado em 1929 para os grupos escolares. Substituto dos antigos batalhões escolares, dele eram obrigados a participar todos os alunos das seções masculinas dos estabelecimentos de ensino estaduais, que seriam dirigidos pelo Diretor Geral da Instrução Pública. A função do escotismo era a prática de "exercicios, tanto quanto possivel militares, para melhor desenvolvimento physico dos alumnos e tambem o conhecimento de maximas civicas para o seu aproveitamento moral" (Decreto n. 3531, de 22 de novembro de 1922, que expediu o Regulamentou para a execução do escotismo em São Paulo).

Outro indicativo de que a formação moral e/ou cívica da criança não poderia ser desprezada é o fato de que, mesmo nos programas de ensino compostos por poucas matérias, foram garantidas oportunidades para que ela ocorresse. No programa destinado às escolas provisórias, por exemplo, além da Leitura, da Escrita e da Aritmética, também deviam ser ensinados a Geografia geral do Brasil e os princípios básicos das Constituições da República e do Estado (Artigo 70 da Lei n. 88, de 08 de setembro de 1892). Por sua vez, no programa de ensino das escolas isoladas de 1911, embora a Instrução cívica e moral e os Exercícios militares tenham sido excluídos do programa anterior, de 1904, o professor devia atentar para observações como essa: "Ao ensino da historia e da geographia prende-se o de instrucção civica. Em tom de palestra desprentenciosa, no alcance de seu auditorio, o professor dará ao alumno a idéa de cidadão, os deveres e os direitos que lhes cabem”.

De qualquer modo, o ensino de virtudes morais e cívicas devia ser a prioridade apenas das escolas-modelo e dos grupos escolares, uma vez que nesses tipos de escolas predominou a estabilidade do elenco de matérias. Nas escolas isoladas, a impraticabilidade do programa de ensino de 1894 motivou o início da produção de programas específicos que, embora não se reduzissem ao ler, ao escrever e ao contar, como desejavam os inspetores escolares, tinham como finalidade primordial infundir na criança o gosto pela vida rural, conforme atestam alguns dos conteúdos referentes à Linguagem oral, à Linguagem escrita e às Ciências 
Naturais, antes mencionados. O programa de ensino publicado em 1913 foi aquele que mais evidenciou a distinção entre as escolas de bairro - como passaram a ser denominadas as escolas isoladas - e as demais modalidades de escolas primárias, já que nele estavam ausentes as matérias cujo intuito era modernizar o ensino, quais sejam, o Desenho, a Ginástica e o Canto e/ou Música.

A despeito do privilégio dado às escolas-modelo e aos grupos escolares, não eram poucos os problemas sociais, relacionados especialmente à Capital, que exigiam respostas por parte dos programas de ensino desses estabelecimentos. Para além da profusão de línguas e de sentimentos cívicos, fruto da heterogeneidade de nacionalidades, havia a circulação, nos espaços públicos, de indivíduos cujos códigos comportamentais escapavam àqueles considerados adequados. Se isso já servia, para as elites responsáveis pela gestão pública, como justificativa para um amplo saneamento moral, o que dizer das formas como as camadas populares conduziam sua vida no âmbito privado? Poderiam as poucas vilas operárias construídas disciplinar essas populações? E quanto aos agitadores misturados "aos bons e laboriosos que procuram nossa terra para ganhar a vida" (In: Revista de Ensino, outubro de 1902, n. 04, ano I, p.585), como denunciava E. Mario de Arantes no texto já referido? Seria o alerta do autor um prenúncio das greves operárias? Como é possível notar, o desejo de nacionalizar e moralizar as crianças em idade escolar que habitavam a cidade de São Paulo não se originou em vão. Convém recordar que o número de grupos escolares sobrepujava o de escolas-modelo e que, ademais, a maioria dos alunos matriculados naqueles era formada por filhos de pais estrangeiros. Assim sendo, depositava-se nessas crianças, futuros cidadãos, a expectativa de que elas fossem não somente amantes da Pátria, como também da ordem. Afinal, como expressa o lema positivista inscrito na bandeira nacional, era preciso, sim, colocar o país no caminho do progresso, mas desde que isso ocorresse no mais absoluto respeito à ordem pública. Referindo-se claramente às manifestações operárias, Guilherme Kuhlmann foi incisivo ao demonstrar a necessidade inadiável do ensino cívico e moral:

$\mathrm{O}$ ensino moderno permitte que perguntemos aos professores que especie de homens pretendem fazer de seus alumnos. É preciso, portanto, que os homens de amanhã, que são os alumnos de hoje, tenham as suas faculdades educadas e sejam os factores do progresso da sociedade, em que vão viver, e, ainda mais, que comprehendam perfeitamente os direitos e os deveres de um cidadão da democracia.

(...) Não nos illudamos com a indole pacifica de nosso povo; os elementos maus ahi estão para arrastar á luta ingloria a pusillanimidade dos espiritos incultos.

(...) No momento actual, em que a indisciplina estende os seus tentaculos peçonhentos, envenenando a conducta dos homens, implantando a desordem e ameaçando as instituições, não seria tempo perdido o mestre dedicar-se a esclarecer bem os beneficios que emanam da ordem (O civismo nas escolas. In: Revista de Ensino, junho-dez./1918, ns. 01-04, ano XVIII, p.17-29). 
Se estava bem delineado o papel das escolas urbanas, as finalidades dos programas de ensino destinados às populações rurais começaram a ser redefinidas a partir da segunda metade dos anos de 1910. Na ocasião, o país assistia ao surgimento de movimentos nacionalistas, desencadeados pela Primeira Guerra Mundial. De modo geral, eles trouxeram à tona temores há muito latentes, tais como o despreparo militar para enfrentar ataques externos; a desconsideração dos brasileiros com os valores nacionais, com os heróis da Pátria e com os fatos mais relevantes da nacionalidade; a ausência de consciência política e de interesse pelo exercício do voto, e o baixo nível cultural da população (Antunha, 1976). Para debelar esses problemas, Olavo Bilac, Miguel Calmon e Pedro Lessa fundaram em 1916, no Rio de Janeiro, a "Liga de Defesa Nacional". As bases de seu programa eram o serviço militar, para a luta contra adversários externos, e a educação cívico-patriótica, crucial para a formação da consciência nacional (Nagle, 1974). Em 1917, foi instituída também a "Liga Nacionalista de São Paulo", que teve muitos adeptos provenientes do magistério, entre os quais Sampaio Dória e Oscar Thompson. No conjunto de metas da organização estavam a criação e a manutenção do sentimento de solidariedade nacional, por meio da idéia de coesão material e moral entre os estados brasileiros, bem como o combate à abstenção eleitoral e a todas as fraudes que corrompessem e viciassem o voto (Antunha, 1976). No segundo caso, era premente erradicar o analfabetismo, já que, a partir da lei eleitoral de 1881, o voto não era mais censitário, e sim direto, desde que o eleitor soubesse ler e escrever (Carvalho, J., 1990).

Mas o que impulsionava tal desafio não eram apenas os planos de ampliar o número de eleitores e de melhorar a qualidade do voto popular. À época, as greves operárias ocorridas na Capital a partir de 1917 fizeram desmoronar a imagem do imigrante como o tipo ideal de trabalhador - laborioso, disciplinado e eficiente - intensamente propalada pelas elites paulistas quando os nacionais eram preteridos em favor daquele (Santos, 2003). Além disso, a Primeira Guerra Mundial havia provocado a interrupção do fornecimento de mão-de-obra para as lavouras de café. Para agravá-la, uma leva constante e numerosa de indivíduos, atraída pela possibilidade de encontrar facilmente ocupações na Capital, despovoavam as fazendas (Morse, 1970). Como manter a economia do país em atividade? A solução foi recorrer a um desacreditado contingente de pobres nacionais (negros libertos, brancos e índios) que - na rígida ordem senhorial e escravocrata e, posteriormente, no projeto imigrantista - foram postos à margem do processo produtivo e, assim, perambulavam sem rumo pelas cidades e campos (Kowarick, 1994). Para isso, "tornava-se imperioso reverter o discurso a fim de arregimentar a mão-de-obra nacional: estava sendo minada a secular percepção segundo a qual os nacionais 
eram vadios, corja inútil imprestável para o trabalho disciplinado" (Kowarick, 1994, p.112). A partir de então, seus defeitos, embora não tenham deixado de ser apregoados, passaram a ser vistos como resultado do abandono ao qual eles haviam sido relegados (Kowarick, 1994). Abria-se, desse modo, a possibilidade de regenerar, por meio da escola, as "populações brasileiras, núcleo da nacionalidade, tornando-as saudáveis, disciplinadas e produtivas" (Carvalho, 1989, p.10).

O primeiro grande passo nesse processo de revalorização dos nacionais foram as iniciativas de Sampaio Dória. O interesse do reformador, cabe lembrar, não era apenas a luta contra o analfabetismo, considerado por ele como entrave para o progresso. A outra face de seu programa era a assimilação dos imigrantes, sem a qual os brasileiros poderiam ser dominados em sua própria terra (Antunha, 1976). Em comum, ambas as questões visavam à

\begin{abstract}
integração do habitante do Estado de São Paulo - nacional e estrangeiro - na vida brasileira. Precisava-se transformar o filho do caboclo e do estrangeiro em verdadeiros brasileiros, em verdadeiros paulistas, coisa que nem um nem outro era até o momento - um, o caboclo, em razão de seu nível cultural inferior, e o outro, o descendente do imigrante, porque estava sendo formado para se tornar um cidadão leal à terra de seus pais e não à terra em que nascera (Antunha, 1976, p.40).
\end{abstract}

Antes mesmo da Reforma de 1920, contudo, determinadas ações do poder público já sinalizavam a intenção de se recuperar física e moralmente o brasileiro, a fimm de introduzi-lo no mundo do trabalho agrícola. Nos Anuários do Ensino de 1918, são recorrentes os relatos de que havia sido criado, na cidade de São Paulo, um curso de Higiene, ministrado no Instituto Butantã aos professores públicos paulistas e dirigido pelo Dr. Vital Brasil. Tido como uma obra patriótica e humanitária, tratava-se da primeira vez em que o governo voltava sua atenção para o grande contingente populacional que, até o momento, nenhum espaço tinha num projeto de modernização cuja primazia foi dada ao saneamento da Capital. Foi preciso, pois, que os brios nacionalistas viessem à tona para que o imaginário das elites passasse a ser povoado de visões de

populações doentias que vegetavam miseravelmente no seio de uma natureza luxuriante e bella e exuberante de força vital. (...) O curso (...) encerra ensinamentos uteis e praticos, sobre as transmissões de molestias, parasitas intestinaes, molestias bacterianas, molestias virulentas, intoxicações, molestias oriundas de protozoarios e sobre a agua e as instalações sanitarias. Armados dessas noções, poderá o professor derramar pelas camadas populares os imprescindíveis conhecimentos de hygiene publica elementar, habilitando assim os moradores da zona rural, não só a evitar as molestias a que estão endemicamente sujeitos, como tambem a saber os meios de lhes dar combate efficaz (Anuários do Ensino de 1918, p.748). 
Paralelamente a isso, o programa de ensino das escolas isoladas rurais, de 1918, demonstra que, diferentemente do programa de ensino das escolas de bairro, de 1913, a ênfase, agora, devia recair na moralização e na nacionalização das crianças residentes no campo, apesar da duração de 2 anos do curso ter sido mantida. Além da ampliação do rol de matérias, semelhante ao do programa dos grupos escolares publicado simultaneamente, foram retiradas expressões que acabavam por configurar como superficial o ensino de matérias fundamentais para despertar o sentimento de patriotismo. Nesse caso, um exemplo nítido eram os antigos conteúdos de História do Brasil: "Palestras com os alumnos, para que tenham uma ligeira noção do municipio no Estado, e do Estado do Brasil"; "Contos muito breves sobre factos da vida de grandes homens"; "Ligeiras noções sobre explorações feitas no Brasil". Em seu lugar, foram inseridas prescrições como, por exemplo: "Palestras com o alumno sobre o logar onde elle nasceu, onde nasceram seus irmãos, seus paes e pessoas conhecidas, de modo a dar-lhe a idéa de Patria. Nome de nossa Patria"; "Palestras sobre as riquezas e bellezas naturaes e recursos de nosso paiz, de modo a despertar na criança sentimentos de enthusiasmo pela Patria"; "Conhecimento dos vultos mais notaveis de nossa Historia". Além disso, se antes devia ser ensinada apenas a Educação cívica, a Instrução moral e cívica passou a fazer do novo programa, sendo que, a partir dela, os alunos deviam, por exemplo, recitar trechos morais e cívicos, previamente explicados pelo professor. Também em relação a essa matéria, conteúdos como "Descrições muito simples da Bandeira Nacional” foram substituídos por outros, a saber, “A Bandeira Nacional. Festa da Bandeira”.

Quando teve início a Reforma, não houve alterações profundas no programa de ensino das escolas isoladas, como já adiantado. Desse modo, a despeito dessa medida ter fícado conhecida como aquela que procurou promover a alfabetização em massa, o ensino primário que passou a vigorar com ela não tinha como objetivo apenas generalizar as habilidades de leitura, de escrita e de cálculo, mas ainda, como afirmava o próprio Sampaio Dória nos Anuários do Ensino de 1918, "assegurar a saude e o vigor do corpo; saber ver, ouvir e mover-se; ensaiar a imaginação e o raciocinio; começar habitos de disciplina moral e civica" (p.61; grifos meus). Por outro lado, também em termos quantitativos, a Reforma buscou retirar o caboclo do alheamento a que ele foi historicamente deixado. De fato, Dória notou que, embora as taxas de analfabetismo fossem elevadas em todo o Estado de São Paulo, elas eram ainda mais graves em relação às crianças das zonas rurais: em 1919, 492.278 crianças formavam a população escolarizável, mas somente $50 \%$ delas freqüentavam as escolas. Desse público escolar, o total de crianças matriculadas nos grupos escolares, nas escolas isoladas e 
nas escolas reunidas do Estado era, respectivamente, de 111.135, de 61.297 e de 7.443 . Assim, eram as escolas graduadas aquelas que supriam a maior parte da demanda e, conseqüentemente, as demais modalidades de escolas atendiam poucas crianças. Diante disso, a decisão tomada foi não apenas interromper a implantação de novas unidades de grupos escolares, como ainda diminuir seu número de classes e de matrículas. Ademais, estava prevista a criação de duas mil escolas isoladas, bem como o desdobramento daquelas existentes. O resultado disso foi o aumento dos índices de matrículas nas escolas isoladas no Interior, apesar do número delas ter se mantido estável. Na Capital, por sua vez, a queda nas matrículas foi ocasionada pela transformação de muitas das escolas isoladas em escolas reunidas que, como visto, foi o tipo de escola que mais cresceu ao longo da vigência da Reforma de 1920. A propósito, conforme Sud Mennucci, a principal vantagem das escolas reunidas, notadamente das rurais, foi a criação da atmosfera cívica:

(...) Nucleos de populações ruraes, onde nunca se viu uma bandeira nacional, onde nunca resoaram as notas alacres e magestosas do hymno de Francisco Manoel, onde nunca se commemorou uma data civica ou um feriado da Republica, aprenderam, de repente, só pela installação das Escolas Reunidas, que o nosso paiz tinha um symbolo, bello e magnífico, de tanto vel-o tremular no mastro do edifício escolar; aprenderam que a nossa patria tinha uma voz de tanto ouvir o Hymno Nacional cantado pela bocca de seus proprios filhos, aprenderam que ha dias de significação especial para a nossa vida collectiva, dias que merecem um culto perenne e solenne, porque relembram feitos e heroes cuja memoria é o orgulho de nosso povo (Anuários do Ensino de 1923, p.133).

No caso dos imigrantes, a intervenção nas escolas particulares, iniciada com a obrigatoriedade do ensino da língua nacional, da Geografia e da História do Brasil, foi reforçada a partir da Reforma Sampaio Dória. Desde então, esses estabelecimentos deviam: "respeitar os feriados nacionais; ministrar, ou fazer ministrar o ensino em vernáculo, salvo o de línguas estrangeiras; incluir no programa, em número de aulas que o Governo determinar, o ensino de português por professores brasileiros natos, ou portugueses natos e o de Geografia e História do Brasil, por professores brasileiros natos, uns e outros de competência reconhecida (...); ensinar nas classes infantis cantos nacionais, aprovados pela Diretoria Geral da Instrução Pública" (Decreto n. 3356, de 31 de maio de 1921).

Se nas escolas particulares o cuidado foi redobrado, nas escolas públicas primárias, especialmente nos grupos escolares da Capital, o ensino das matérias que concorriam para a formação da nacionalidade brasileira, ao que parece, ocupava cada vez mais o horário das aulas. É o que ilustra a passagem abaixo, extraída do livro Brás, Bexiga e Barra Funda, publicado em 1927 e de autoria de Antônio de Alcântara Machado: 
No Grupo Escolar da Barra Funda Aristodemo Gugianni aprendeu em três anos a roubar com perfeição no jogo de bolinhas (garantindo o tostão para o sorvete) e ficou sabendo na ponta da língua que o Brasil foi descoberto sem querer e é o país maior, mais belo e mais rico do mundo. O professor seu Serafim todos os dias ao encerrar as aulas limpava os ouvidos com o canivete (...) e dizia olhando o relógio:

- Antes de nos separarmos, meus jovens discentes, meditemos uns instantes no porvir da nossa idolatrada pátria.

Depois regia o hino nacional. Em seguida o da bandeira. O pessoal entoava os dois engolindo metade das estrofes (...) (MACHADO, Antonio de Alcântara, 1997, p.32).

Se o trabalho nacionalizador estava sendo realizado nas escolas urbanas, o receio de formação de "quistos étnicos" - comunidades nas quais a língua, os costumes e as tradições fossem exclusivamente estrangeiros, a ponto de impedir a entrada de professores e também de escolas nacionais (Duarte, 1995) - era mais acentuado em relação às escolas rurais. Com efeito, os imigrantes

que se aboletam nas cidades facilmente se matriculam nas escolas diurnas, quando menores, e nas nocturnas, quando adultos, aprendendo, numas e noutras, a falar a nossa língua e recebendo noções elementares de arithmética, geographia e história pátria; os que se estabelecem nos campos e nas fazendas, distantes dos centros urbanos, vivem, crescem e prosperam na completa ignorância da língua, do meio, dos usos e costumes, dos nossos recursos, inteiramente estranhos à vida social e política do país que lhes dá hospitaleiro agasalho e fartura (Anuários do Ensino de 1917, p.131).

Os descendentes dos caboclos e os dos estrangeiros residentes no campo eram, portanto, as principais fontes de preocupação do poder público. Era preciso que o professor desenvolvesse em ambos o amor pela Pátria, fundamental para o futuro dela:

O que a escola tem que fazer é pensar, e pensar sériamente nos filhos do caboclo e nos do estrangeiro. Esses é que são a materia prima para a formação das novas gerações com ideaes mais elevados, gerações que deverão attestar perante o mundo civilizado a nossa capacidade para a ordem e para o progresso (Anuários do Ensino de 1918, p.746).

Com a derrubada da Reforma Sampaio Dória, em 1925, os perigos da difusão do alfabeto passaram a ser o mote da Associação Brasileira de Educação (ABE). Isso porque, como esclarece Carvalho (2000), mal interpretada no seu intuito pedagógico e político de condensar a educação popular em um curso básico de dois anos de duração, ela foi eleita como o símbolo daquilo que devia ser evitado: o ensino primário incompleto para todos, isto é, a escola alfabetizante. Fundada em 1924, no Rio de Janeiro, a ABE era uma organização cívica, que ganhou o âmbito nacional ao promover, a partir de 1927, as chamadas 
Conferências Nacionais de Educação ${ }^{92}$. Para ela, educar não significava instruir, pura e simplesmente, mas sim moldar o povo brasileiro, "matéria informe e plasmável, conforme os anseios de Ordem e Progresso de um grupo que se auto-investia como elite com autoridade para promovê-los" (Carvalho, 1989, p.09). Nesse projeto nacionalista marcado pelo autoritarismo, saúde, moral e trabalho configuravam o trinômio sob o qual se apoiaria a educação integral, concebida como a única capaz de evitar a desestabilidade social. De fato, cada vez mais, a vida nas grandes cidades tornava-se, para as elites, uma experiência singular, dado que provocava nelas um sentimento misto de encanto e insegurança (Veiga, 2000). De um lado, largas avenidas, equipamentos urbanos, grandes construções, jardins, automóveis, entre outros signos da modernidade, davam a elas a sensação de que o progresso era irreversível. De outro lado, as imagens de uma turba pronta a invadir seus espaços de circulação - formada por operários contaminados com o "vírus anarquista" (Kowarick, 1994, p.113), mendigos, loucos, pobres, negros, prostitutas e, principalmente, camponeses inquietavam-nas. Por isso, foram formuladas propostas para conter, nas palavras de Fernando de Magalhães, membro da ABE, essa "distribuição humana desordenada" (Combate ao analphabetismo na zona rural. In: Educação, outubro de 1929, n. 01, vol. IX, p.78). Uma delas era uma ampla moralização dos costumes citadinos, a ser realizada, por exemplo, através de comemorações cívicas, de festas pedagógicas, das denominadas Semanas de Educação ${ }^{93}$ e do escotismo. A outra procurava equacionar os fluxos migratórios entre campo e cidade, ou seja, fixar o homem no primeiro, o que exigia a criação de uma "Escola Regional" 94, onde os benefícios da vida rural, como a simplicidade, a honradez e a salubridade, seriam contrapostos aos efeitos nocivos do meio citadino (Carvalho, 1989). Aludindo às escolas rurais, Lourenço Granato, autor do texto intitulado $\underline{\text { A alphabetização em }}$ $\underline{\mathrm{SP}}$, concordava com a idéia da $\mathrm{ABE}$ de que a mera alfabetização traria riscos que, nesse caso, consistia no êxodo rural e no conseqüente inchaço das cidades:

\footnotetext{
${ }_{92}$ Muitas das teses apresentadas nessas Conferências foram publicadas na revista Educação.

${ }^{93}$ As "Semanas de Educação" "consagravam a cada dia um tipo de celebração: do Mestre, do Lar, do Trabalho, da Saúde, da Fraternidade e outros arquétipos. Assim, palestras, festas, prêmios, competições, inaugurações, exposições eram organizados em diversas escolas e locais públicos, cultuando signos de autoridade e hierarquia e ritualizando, no espetáculo cívico, modelos de comportamento exemplar" (Carvalho, 1989, p.78).

94 A proposta de uma "Escola Regional" remete ao ruralismo, "um instrumento que dificultava alterações na estrutura econômico-social pela disseminação de mitos da idade do ouro e pelo avivamento de suportes saudosistas, em cujo cerne se encontrava a idéia de que a vida campesina representa o ambiente ideal para a formação de homens perfeitos, isto é, saudáveis, retos, solidários, respeitáveis. (...) Fundamentando-se na exaltação das vantagens 'naturais' da vida rural, difunde uma atitude pessimista, que encobre interesses contrariados pelo meio citadino. Este é acusado de artificial, destruidor da solidariedade 'natural' do homem" (Nagle, 1974, p.26). Segundo Demartini (1980), o ruralismo intensificou-se no período entre 1930 e 1960 e tinha Sud Mennucci como um dos seus principais representantes.
} 
(...) segundo o nosso modo de encarar o problema da alphabetização, com a criação das escolas ruraes, os resultados que se poderão conseguir, só produzirão os melhores effeitos se fôr introduzida nos programmas do ensino escolar, qualquer cousa que afeiçôe as crianças á terra e as anime a não se divorciarem della, afim de, por qualquer forma, amá-la e cultivá-la, afastando, desse modo, os perigos, agora tão patentes, do êxodo dos campos.

Todos nós sabemos que, na mór parte, o filho do agricultor que moureja na vida rural tende a emancipar-se della, quando adquiriu na escola uma cultura, embora superficial, que mal o habilita a ser caixeiro de uma loja ou armazem, ou dactylographo ou, por fim, candidato a... contador, como os ha, aos milhares, na nossa Capital.

Se nas escolas ruraes, tão acertada e patrioticamente criadas, não se fizer qualquer cousa que desperte nos alumnos o amor pela vida do campo; queremos dizer, que se, pelo menos, nessas escolas não se conseguir incutir no espirito dos alumnos a compreensão de que 'o solo é a patria' e que 'cultivá-lo é engrandecê-la', essas escolas, sem duvida, poderão resolver satisfactoriamente o patriotico problema da alphabetização, mas, trarão, fatalmente, como consequencia, mais ou menos accentuada, o êxodo dos campos, o qual constituirá um dos mais perigosos factores de decadencia economica das nossas finanças (In: Educação, outubro de 1928, n. 01, vol. I, p.51-52).

No que tange aos programas de ensino oficiais, idéias semelhantes às da ABE já podiam ser vislumbradas mesmo antes da Reforma de 1920. Exemplo disso é o fato de que, nos três programas de ensino publicados em 1918 para as escolas isoladas (rurais, distritais e urbanas), os conteúdos de Trabalhos manuais - os quais anteriormente se destinavam só às meninas e se resumiam ao crochê e à costura - passaram não apenas a ser obrigatórios também para os meninos, como ainda a ser compostos de atividades associadas ao meio rural, de modo a fazer com que ambos os sexos se interessassem pelo trabalho agrícola. Ao contrário das críticas da $\mathrm{ABE}$, o programa de ensino instituído com a Reforma manteve tais prescrições. Exceção entre as demais matérias, os Trabalhos manuais eram a única cujos conteúdos se diferenciavam conforme o tipo de escola: "Nas escolas ruraes e districtaes - a) Trabalhos praticos de horticultura, arboricultura e jardinagem; b) Feitura de utensilios simples e necessarios a esses trabalhos que se possam realizar com o material encontrado nas visinhanças da escola. (...) Nas escolas districtaes e urbanas - a) Dobramento de papel. Objectos usuaes: chapéus, barquinhas, caixinhas, etc; b) Tecidos de papel; c) Alinhavos em cartões, á vista de modelos apropriados e graduados; d) Modelagem: construcção de fórmas geometricas já estudadas” (Decreto n. 3356, de 31 de maio de 1921). Desse modo, no programa de ensino publicado em 1929 para as escolas rurais (reunidas e isoladas), a prescrição de que os trabalhos manuais deviam estar relacionados à zona da escola representou tão somente um retorno ao que já se realizava para impedir que as crianças que habitavam o campo se sentissem impelidas a migrar para as cidades. 
Tornar cada criança não apenas um cidadão integralmente educado, como também capaz de contribuir para o progresso e a civilização do país. Eis os objetivos gerais que costumam ser associados aos programas do ensino primário. A análise dos conteúdos prescritos para cada matéria, bem como os textos das revistas pedagógicas e os relatórios dos inspetores escolares mostram, entretanto, que o papel da escola primária devia ser, primordialmente, o de fazer com que esse futuro cidadão amasse a Pátria, tivesse um bom caráter e soubesse cumprir seus deveres (no que dependesse dos conteúdos, eram poucos seus direitos). Visíveis desde os programas de ensino publicados nos anos de 1890, essas duas finalidades tornaram-se prementes no auge do nacionalismo. Até então, somente as escolasmodelo e os grupos escolares puderam, sem interrupção, colocar o foco do curso primário na educação moral e cívica. Embora fossem muitas as necessidades sociais que deviam ser contempladas por essas escolas urbanas, a marginalização das populações rurais atestava o nulo comprometimento do poder público com essas parcelas da sociedade. Ao terem seus programas diferenciados daqueles dois tipos de escolas primárias, às escolas isoladas restaram oferecer um curso que, sofrendo a instabilidade das matérias, devia apenas alfabetizar as crianças e desenvolver nelas o prazer de habitar o campo, por meio, principalmente de rudimentos científicos. A partir dos anos finais da década de 1910, a inflexão no discurso educacional vai propiciar aos filhos do caboclo a oportunidade de serem lembrados pelos governantes paulistas. Longe de constituírem atos de benevolência, porém, o referido curso de Higiene e as mudanças trazidas pelo programa de ensino das escolas isoladas rurais publicado em 1918 tinham como intuito garantir que aqueles futuros trabalhadores fossem sadios, moralizados e ardorosos defensores da Pátria. Com a Reforma de 1920, tais planos reservados aos "caboclinhos" não foram prejudicados. Por outro lado, tendo a duração de seu curso reduzida à metade, os grupos escolares precisaram adaptar, aos limites do novo programa, seu projeto de nacionalizar e moralizar as crianças residentes nas cidades. Finda a Reforma, a constatação de que crescia o êxodo rural motivou a retomada da distinção dos programas de ensino. Com isso, os grupos escolares voltaram, até 1929, a perseguir suas metas iniciais. Quanto às escolas isoladas rurais, cujos programas de ensino passaram, a partir de 1926, a ser estendidos também às escolas reunidas rurais, elas continuaram com o seu propósito de regenerar física e moralmente os descendentes de caboclos para torná-los aptos ao trabalho agrícola e, assim, colaborar com o engrandecimento da Pátria. 


\section{Capítulo 3 - A interação entre os diversos sujeitos escolares e os programas de ensino}

O segundo capítulo mostrou três exemplos de como, à época da publicação dos programas de ensino, a relação entre os profissionais da educação e as normas esteve longe de ser pacífica: no primeiro deles, certos professores não aceitaram bem o fim do ensino religioso nas escolas públicas. Em outro, alguns colaboradores da Revista de Ensino acolheram com críticas severas a publicação, em 1905, do programa de ensino das escolas-modelo e dos grupos escolares. Por último, os inspetores escolares, ao avaliarem como inadequada a adoção do programa de ensino das escolas preliminares (1893 e 1894) nas escolas isoladas, sugeriam a elas a confecção de um programa próprio. Assim, embora as expectativas do Estado fossem a pronta aceitação e a obediência irrestrita aos programas de ensino, o estudo dos textos das revistas pedagógicas e, especialmente, dos relatórios de ensino produzidos por professores, por diretores de escolas-modelo e de grupos escolares, e por inspetores escolares permitiu entrever que, na prática, aquelas permaneceram apenas no plano do idealismo. Em outros termos, a despeito do caráter impositivo da legislação escolar, é preciso não desconsiderar que a mesma é também lugar de conflitos, tensões e lutas, o que torna contestável a passividade comumente atribuída aos sujeitos escolares com aquela envolvidos.

O presente capítulo visa a realçar essa participação ativa dos diversos profissionais da educação quando se tratava de debater a questão do que ensinar nas escolas primárias. Para isso, ele é dividido em três partes. Na primeira delas, alguns deles tecem referências gerais sobre o problema, como por exemplo, qual seria o programa de ensino ideal e os deveres dos professores em relação a esse. Em seguida, é mostrado como o programa de ensino consistia num objeto de disputas entre os agentes escolares, ou seja, cada um deles, divergindo do que era prescrito, procurava expressar suas opiniões acerca de quais saberes escolares deveriam ser transmitidos às crianças. Na última, são assinaladas as distâncias entre aquilo que determinavam os programas de ensino e o que se ministrava nas escolas, decorrentes de três diferentes fatores: a falta de condições materiais, a formação inadequada dos professores e a preferência dada por eles e pelos diretores de escolas-modelo e de grupos escolares a determinadas matérias. 


\subsection{Considerações gerais em torno da questão dos programas de ensino}

Em texto incluído no primeiro número da Revista de Ensino, Romão Puiggari conclamava a necessidade da sistematização do ensino, tida como uma etapa posterior à organização do aparelho escolar. No parecer do autor, como a excelência desse já havia sido comprovada, era preciso agora preocupar-se com a sua uniformização, especialmente no que se referia à questão do programa de ensino. Alçando esse componente da cultura escolar à condição de proeminência, Puiggari defendia que, sem um bom programa de ensino, não haveria uma boa escola. Para tanto, aquele devia, antes de tudo, ser elaborado pelo próprio professor. Isso porque "é elle que está apto para estabelecer a dosagem nas disciplinas de cada um dos annos em que se divide o curso. Fazer um programma no gabinete é o mesmo que estudar chimica sem laboratorio, pathologia sem hospitaes" (A questão dos programmas. In: abril de 1902, n. 01, ano I, p.14). À época, o autor era redator-secretário do periódico educacional e, assim como os demais colaboradores, fazia parte do magistério público. De fato, eram eles professores das principais escolas públicas paulistas e, como tais, tomavam como legítima sua experiência para apresentar, através da publicação, aquilo que concebiam como a organização do ensino modelar. Reivindicando, desde o início, que as questões relacionadas ao ensino deviam ser tratadas não por políticos, mas sim por educadores (Catani, 2003), os produtores da revista visavam, conforme o primeiro editorial, a

orientar o governo e os nossos legisladores na elaboração das leis futuras sobre instrucção publica.

O professor primario, como elemento modificador, e o mais importante, na evolução social, não póde nem deve mais, como tem feito até o presente, conservarse inactivo e indifferente á feitura das leis de que elle é a parte mais interessada, cabendo-lhe, como executor, a principal funcção e responsabilidade (abril de 1902, n. 01, ano I, p.03).

No caso dos programas de ensino, é possível notar o desejo de que o professor primário, mais do que simplesmente colocá-los em prática, pudesse participar ativamente de sua construção. Assim, não deixava de ser adequado o termo cunhado por Guilherme Kuhlmann para se referir ao professor primário, a saber, "o silencioso operario da civilização e do progresso, a quem está ligada a grandeza da nação" (O civismo nas escolas. In: Revista de Ensino, junho-dez./1918, ns. 01-04, ano XVIII, p.15). Afinal, o docente recebia, por parte do Estado, um tratamento profundamente contraditório: ao mesmo tempo em que sob ele pesava a difícil tarefa de educar aqueles considerados o futuro da Pátria, sua voz não era 
ouvida, já que ele não era chamado a opinar no que dizia respeito ao processo de criação dos programas de ensino. Em suma, o professor primário era um profissional de quem muito se exigia, mas ao qual pouco se oferecia.

Em virtude disso, Puiggari propunha, no mesmo artigo, três diferentes formas de colaboração docente. Uma delas era organizar uma comissão de professores, que consultaria qualquer integrante do magistério. Em outra, uma ou mais escolas seriam convidadas a apresentar os programas de ensino em prazo definido. Por fim, poderia ser realizado um concurso, com ou sem prêmios e dirigido a todos os professores. Porém, seriam necessárias que fossem fixadas as condições, a fim de se assegurar um julgamento inteiramente imparcial. Além disso, os projetos de programas poderiam ser assinados, em envelopes lacrados, por pseudônimos, tal como nos concursos literários.

Também nesse texto, o autor sugeria que outro critério sob o qual deviam ser baseados os "bons" programas de ensino é o da dosagem equilibrada das matérias. Desse modo, nenhuma delas prejudicaria as demais. Para isso, ele recomendava a organização do tempo de trabalho escolar por meio de um horário racional, isto é, que calculasse a parte que cumpria a cada matéria. O resultado desse cálculo seria, na opinião de Puiggari, tão diminuto, que ninguém teria a coragem de apresentar programas de ensino que não fossem limitados. As vantagens de programas de ensino como esses seriam duas: possibilitar as repetições, uma vez que nelas estaria o segredo do ensino primário, “dizia o dr. Menezes Vieira; e não invadir o tempo destinado a outras materias. Os programmas muito extensos, apenas se prestam a pomposas exhibições nos exames finaes (...)" (grifos do autor; A questão dos programmas. In: Revista de Ensino, abril de 1902, n. 01, ano I, p.14).

O alerta de que nenhuma matéria devia ser privilegiada também partiu de outros autores, como Ramon Roca Dordal. Como explicitado anteriormente, ele criticou a ênfase dada às Ciências no programa de ensino das escolas preliminares de $1894 \mathrm{e}$, por isso, sublinhava que não se "deve dar a certas partes do programma, a certas disciplinas, uma extensão tal que as transforme em cursos especiaes" (Um assumpto de actualidade. In: Revista de Ensino, outubro de 1902, n. 04, ano I, p.588). Além da preocupação com a exigüidade do tempo, a amplitude dos programas de ensino era vista como inapropriada para o nível primário, em virtude da faixa etária do público ao qual se destinava. Com efeito, Augusto de Carvalho declarava que a "sobrecarga do programma é sempre nefasta: (...) a ideia de apprender poucas coisas, mas de apprende-las a fundo, deve ser a ideia capital do ensino. É preciso que não nos esqueçamos de que um alumno do curso primario é um viajante 
em principio de jornada" (grifos do autor; $\underline{\mathrm{O} \text { actual programma de ensino dos grupos e da }}$ escola-modelo I. In: Revista de Ensino, junho de 1909, n. 02, ano VIII, p.07). Também mostrando-se de acordo com a concepção de infância como uma fase da vida cujas especificidades precisam ser contempladas, o inspetor escolar José Narciso de Camargo Couto afirmava ser favorável à simplicidade dos programas de ensino:

\footnotetext{
Um longo e apparatoso programma é um trabalho, sinão um mal para o destino da escola. (...)

Encher-se o cerebro ainda em formação da criança de uma terminologia inutil e incomprehensivel, de classificações mais ou menos arbitrarias, de divisões e subdivisões fatigantes, é uma indizivel crueldade. Ainda mais: dictarem-se estas cousas todas, submettendo os jovens estudantes a um acto de mera decoração, é um crime.

(...) Si se attendesse sempre a que a intuição é a alma do ensino primario, si bem e fielmente se seguissem os sabios conselhos dos velhos mestres (Pestalozzi em primeiro logar), a grande extensão do programma não seria tão prejudicial (...) (Anuários do Ensino do Estado de São Paulo de 1910-1911, p.62).
}

Como adiantado, a escolha do método intuitivo para a aplicação dos programas de ensino foi embasada justamente pela busca em adequar a organização do ensino primário ao desenvolvimento natural da criança: "As licções sobre as materias de qualquer dos annos do curso deverão, de accôrdo com o programma adoptado, ser mais praticas e concretas do que theoricas e abstractas, e encaminhadas de modo que as faculdades das creanças sejam incitadas a um desenvolvimento gradual e harmonico" (Art. $6^{\circ}$. do Decreto n. 1216, de 27 de abril de 1904). Apesar da adoção desse método de ensino nas escolas primárias, a insistência no cumprimento de programas de ensino enciclopédicos tornou-se um enorme desafio para os professores, conforme será explicado depois.

Ainda no que tange à relação entre os programas de ensino e as particularidades do ensino primário, vale mencionar um tema ainda pouco estudado, qual seja, a natureza dos saberes escolares que fazem parte dos primeiros. Diferentemente do nível secundário, onde prevalece uma forte e nítida separação entre as disciplinas, mesmo porque cada uma delas é lecionada por professores especializados (Forquin, 1992), no ensino primário é difícil traçar as fronteiras entre as matérias. Não à toa, uma mesma finalidade poderia - e deveria - ser alcançada por meio de várias delas, como era o caso da moralização e o da nacionalização das crianças. Chervel (1992, p.215) denomina essa colaboração mútua de "solidariedade didática". Além dessa característica, os saberes escolares que integram os programas do ensino primário apresentam outras duas (Souza, 2005). De um lado, eles mantêm uma fraca ligação com as ciências de referência. É o que mostra Hébrard (1990) ao aludir à trilogia lerescrever-contar. Interessado em responder se haveria um lugar para esses saberes elementares 
na história das disciplinas escolares, o autor é direto: as primeiras aprendizagens "são savoirfaire, sem correspondentes nas ciências e sua hierarquia" (1990, p.65). Os saberes elementares, assim, teriam se escolarizado, entre o final da Idade Média e o Renascimento, através da junção de duas culturas profissionais: a dos clérigos e a dos mercadores (Hébrard, 1990). Além desses elementos culturais, outros, também de origens distintas, podem ser encontrados nos programas do ensino primário, tais como noções científicas, símbolos, valores, competências, procedimentos e habilidades (Souza, 1997; 2005). De outro lado, os saberes escolares ensinados nas escolas primárias são resultado de um processo chamado por Forquin (1992) de "transposição didática", isto é, antes de serem transmitidos diretamente aos alunos, eles devem sofrer uma transformação que os torne assimiláveis.

Em artigo publicado na Revista de Ensino, Arnaldo Barreto, então seu redator-chefe, apesar de concordar com Romão Puiggari de que, para uma boa escola, é fundamental um bom programa de ensino, fazia a seguinte ressalva: "ele, por si só, sem a orientação do methodo, sem a indicação do fim que visa, entregue assim desencarnado ás mãos do mestre inexperiente, será sempre um esqueleto, a que apenas poderá dar fórma a intuição natural de um espirito eminentemente educativo, ou já orientado nas lides do magistério" (As conferencias mensaes. In: junho de 1902, n. 02, ano I, p.157). A mera existência do programa de ensino, pois, seria insuficiente para o professor sem a prática de ensino. Nesse sentido, o autor levantava a idéia da realização de conferências mensais nos grupos escolares de todo o Estado, das quais também participariam os professores das escolas isoladas de todo o município. Nelas seriam debatidas teses relativas não apenas ao ensino de cada matéria e à sua finalidade, como ainda a temas mais gerais, como disciplina, deveres do professor no tocante aos alunos e a suas famílias e aos de ambos em relação àqueles, entre outros. Além disso, à medida em que as discussões fossem ocorrendo, elas seriam "inseridas e criticadas na Revista, disseminando-se assim conhecimentos pedagogicos seguros, que constituiriam a base necessaria para a promta e nitida comprehensão dos referidos programmas" (As conferencias mensaes. In: junho de 1902, n. 02, ano I, p.158). Tais conferências, assim, mais do que complementos dos programas de ensino, consistiriam numa forma de se obter a tão almejada padronização do ensino, dado que, a partir delas, o professor saberia "dar ao programma, não MAIS OU MENOS, mas a perfeita execução que elle solicita" (grifos do autor; $\underline{\text { As }}$ conferencias mensaes. In: Revista de Ensino, junho de 1902, n. 02, ano I, p.157). Por sua vez, 
a publicação das teses no periódico remete à importância desse tipo de impresso enquanto veículo de circulação de saberes pedagógicos, fundamentais para o aperfeiçoamento do trabalho docente (Catani, 1998).

O texto Nossos programmas de ensino - inserido na Revista Escolar e assinado somente com as iniciais J. V. - classifica como o bom professor aquele que, antes de executar o programa de ensino, estuda-o profundamente. Assim sendo, ele procurava ampliar o já extenso rol de responsabilidades do docente:

\footnotetext{
Não pense nunca o mestre, que, para cumprir com seus deveres, é bastante receber sua classe, abrir o programma e começar a segui-lo fielmente, de accordo com a ordem numerica dos pontos nelle contidos. Assim fazendo, elle ensinará muito, dará todo o programma que lhe foi confiado, trabalhará bastante e, ao findar o anno lectivo, ha de forçosamente sentir uma desillusão immensa, ao certificar-se, pelo fracasso dos exames finaes, que gastou inutilmente as suas forças, perdeu o seu tempo, sacrificou o seu physico e toda a sua classe (Nossos programmas de ensino. In: Revista Escolar, fevereiro de 1925, n. 02, ano I, p.102).
}

Pela leitura do artigo, é possível notar que o autor se dirigia ao corpo docente dos grupos escolares. Isso porque ele, em seguida, acrescentou que o professor do $2^{\circ}$. ano primário devia ensinar o programa de ensino do ano anterior ou, ao menos, recordá-lo, antes de iniciar aquele do qual estava incumbido. O objetivo de tal procedimento era homogeneizar o nível de adiantamento dos alunos, levando-se em conta que esse mestre, ao contrário daquele que o antecedia, recebia alunos provenientes não só de diversos primeiros anos, mas também de diferentes professores e escolas.

Se o texto anterior trata de uma das obrigações do professor das escolas graduadas, alguns inspetores escolares, especialmente à época do nacionalismo, apontaram que não bastava àquele que trabalhava nas escolas rurais apenas seguir os programas de ensino: ele tinha ainda de estabelecer estreitas relações com a população do campo. Para tanto, além de residir no entorno da escola, o mestre devia realizar visitas constantes ao caboclo e a suas famílias, aconselhando-os, orientando-os e dando-lhes exemplos, sobretudo no que dizia respeito às regras de higiene. Só assim ele poderia, como resume Antonio Alves Aranha, "tornar-se acessivel, affavel, respeitado e estimado pela gente rústica" (Anuários do Ensino

de 1918, p.807). No entender de Romano Barreto, para que tal missão fosse possível, eram indispensáveis ajustes nos cursos responsáveis pela formação docente: “Não poderemos 
praticar melhor serviço do que aquelle de dar aos estudantes das Normaes, noções da psychologia da gente rural, ella tem as suas particularidades, os capitulos variaveis com o meio, os termos com outras significações" (grifos do autor; Anuários do Ensino de 19201921, p.283). O professor da escola rural precisaria, portanto, receber ensinamentos específicos para que pudesse manter contato com os moradores do campo. Convém recordar que, pela Lei n. 930, de 13 de agosto de 1904, os mestres recém-formados deviam iniciar a carreira nas escolas isoladas, mas, muito provavelmente, estavam pouco acostumados à vida rural $^{95}$.

\subsection{O que ensinar como objeto de disputas}

Em abril de 1903, na seção "Noticiário", o texto intitulado Programma de ensino dava a informação de que transitava, entre os responsáveis pela Revista de Ensino e demais componentes do professorado público, a idéia de se produzir um novo programa de ensino. De acordo com o mesmo texto, após terem se ocupado em definir as bases necessárias para a organização do programa, os primeiros solicitaram do magistério público paulista respostas para indagações tais como essa:

Qual a porcentagem que deve caber aos seguintes grupos de materias:

$1^{\circ}$. - Linguagem

$2^{\circ}$. - Mathematica (Arithmetica e Geometria)

$3^{\circ}$. - Desenho, calligraphia, trabalho manual e musica (Educação artistica e manual)

$4^{\circ}$. - Instrucção civica, Historia patria e Geographia do Brasil (Educação civica)

$5^{\circ}$. - Historia natural, Physica, Chimica, Cosmographia e Geographia geral (Educação scientifica)

$6^{\text {o }}$ - Gymnastica (Educação physica) (Programma de ensino. In: Revista de Ensino, abril de 1903, n. 01, ano II, p.99).

A comparação dessas matérias com aquelas prescritas pelo programa de ensino das escolas preliminares (Decreto n. 248, de 26 de julho de 1894) permite entrever que não havia

\footnotetext{
${ }^{95}$ Entre maio e agosto de 1930, a revista Educação, a mesma aqui tomada como fonte, publicou uma série de opiniões emitidas pelo professorado paulista sobre o inquérito enviado pelo então Inspetor Geral do Ensino, João Augusto de Toledo. Intitulado "Como preparar o professor rural e fixá-lo ao meio em que deve atuar", uma das cinco questões formuladas era sobre qual deveria ser a feição dominante do programa de ensino das escolas normais primárias, como passaram a ser chamadas as escolas complementares a partir de 1911 (Tanuri, 1979). Assim, estava em debate a necessidade ou não de uma formação especial para o professor que iria atuar nas áreas rurais.
} 
diferenças significativas entre o que se ensinava no momento nas escolas primárias e o que planejava o corpo de redatores do periódico, à exceção da "moral prática", ausente no segundo caso. Ao questionar os professores, por exemplo, sobre o tempo a ser consagrado ao ensino de cada conjunto de matérias, o periódico reforçava seu apelo para que a confecção dos programas de ensino - e das leis de uma forma geral - fosse delegada a esses profissionais.

Mais tarde, entre agosto de 1904 e fevereiro de 1905, a Revista de Ensino publicou as denominadas "Conferências do Sr. Carlos Escobar", nas quais a questão dos programas de ensino continuou a ser discutida, sinalizando a insatisfação com o modo como o ensino primário estava estruturado (Catani, 2003). Referindo-se aos grupos escolares, Escobar argumentava que a sua principal função devia ser o ensino da língua materna e que, assim, todas as demais matérias poderiam ser aproveitadas em favor dela. Em outros termos, o autor considerava-o o "centro de gravidade das escolas primarias (...) o esteio mais forte da nacionalidade e o processo natural para estabelecer os laços da solidariedade social" (Conferencia do Sr. Carlos Escobar. In: Revista de Ensino, dezembro de 1904, n. 05, ano III, p.475). Para que sua proposta se concretizasse, Escobar complementou que era imprescindível ampliar para 7 anos a duração do curso dos grupos escolares e dividi-lo em dois períodos. No primeiro deles, de 3 anos, seriam ensinados a crianças de 7 a 10 anos de idade a leitura elementar e os princípios de escrita e de cálculo. No outro, a ser freqüentado, ao longo de 4 anos, por alunos entre 10 e 14 anos, seriam desenvolvidos o ensino das ciências, através da leitura, a expressão oral ou escrita da língua materna, além do cálculo aritmético e geométrico. Quanto aos programas de ensino das escolas isoladas, o autor não via a necessidade de se diferenciá-lo daquele dos grupos escolares:

Esta questão está resolvida por si mesma. Si se estabelece como regra que o ensino da leitura é um meio para aprendizagem dos outros elementos, desapparece a necessidade de differençar o programma dos grupos e das escolas isoladas, desapparece a distincção de um ensino para a roça e outro para a cidade (Conferencia do Sr. Carlos Escobar. In: Revista de Ensino, fevereiro de 1905, n. 06, ano III, p.528).

Em paralelo às conferências proferidas por Escobar, mais precisamente a partir de dezembro de 1904, o periódico começou a veicular uma série de textos intitulados "Opinião" ou "Consulta ao professorado", que consistiam no retorno do magistério à circular enviada, em agosto de 1904, por intermédio da "Associação" (Catani, 2003):

\footnotetext{
${ }^{96}$ Realizadas na sede da "Associação Beneficente do Professorado Público de São Paulo", em 26 de junho de 1904 (Catani, 2003).
} 
Sendo de grande alcance para conseguir-se, em qualquer paiz, uma boa refórma de instrucção popular, conhecer as idéas predominantes na respectiva corporação docente, assim como entre aquelles que se têm occupado desse ramo de serviço publico, peço-lhe que, em fórma de artigo de jornal e com a brevidade que lhe fôr possivel, me envie a sua opinião sobre o systema de instrucção publica correspondente ao actual estado de civilização, ennumerando, como consequencia, as medidas que julga necessarias ao melhoramento do systema em vigor no Estado de S. Paulo.

Mais uma vez, o problema do que ensinar nas escolas primárias tinha destaque nas opiniões emitidas pelos docentes. Para Izidro Denser, por exemplo, aquelas deviam ser dotadas de um programa de ensino simples, exeqüível e eficaz, cujo fim principal fosse o ensino metódico e graduado da leitura, da escrita, da linguagem, do cálculo e da caligrafia. Além disso, o curso primário devia ser dividido em 3 séries ou classes, sendo que nos grupos escolares e nas escolas reunidas essas ficariam sob a direção de um só professor (Opinião. In:

Revista de Ensino, fevereiro de 1905, n. 05, ano III, p.450). Já na avaliação do professor Ernesto Lopes da Silva, o programa de ensino vigente à época nas escolas-modelo e nos grupos escolares devia sofrer alterações. Dessa forma, o curso teria apenas 3 anos, sendo dele excluídas matérias vistas como sem resultados positivos, ou seja, "de pouca utilidade pratica e que mais figuram no actual programma como elementos de pedantismo" (Opinião. In: Revista de Ensino, fevereiro de 1905, n. 05, ano III, p.527). Em relação ao programa de ensino das escolas isoladas, esse devia, no entender do autor, ser distribuído em 3 graus. O primeiro seria dedicado ao ler, ao escrever, ao contar, bem como às noções de história pátria e de geografia do Brasil. Já no segundo, seriam ministradas "sómente as materias do $1^{\circ}$. e $2^{\circ}$. plano; no $3^{\circ}$. o programma dos grupos com menor desenvolvimento, salvo tratando-se de escolas reunidas (...). Penso que é preferivel diminuir as materias e ensinal-as bem, a conserval-as todas e

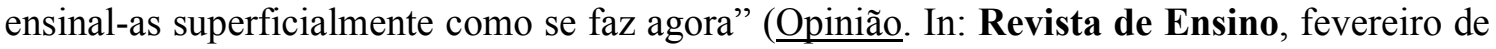
1905, n. 05, ano III, p.527).

Além de Denser e Silva, Emilio A. Ferreira imaginava um ensino dividido em dois cursos, quais sejam, o preliminar e o complementar. O primeiro teria a duração de 2 anos e seria realizado em escolas isoladas, sob a regência de dois professores e com 60 alunos matriculados, ou então em grupos escolares, como curso anexo. Seu programa de ensino seria composto pela língua materna (ler e escrever da forma correta), cálculo sobre as quatro operações fundamentais (números inteiros, decimais e frações) e sistema métrico. A essas matérias, somavam-se as noções de ciências físicas e naturais, mas essas deviam ser ministradas por meio das primeiras, como a leitura. A habilitação no curso preliminar daria direito à freqüência no curso complementar que, por sua vez, se concluído, possibilitaria a 
matrícula em qualquer curso superior do Estado. No caso do segundo, ele seria oferecido nos grupos escolares no decorrer de 3 anos, com um programa de ensino que continha Português, Aritmética, Geografia, História Pátria, Geometria, Noções de Ciências físicas e naturais, Elementos de Álgebra e língua francesa. Convicto de suas idéias, Ferreira não poupava esforços para justificá-las:

Em geral, as crianças, quando sabem ler regularmente, escrever menos mal e calcular um pouquinho, deixam a escola para entregar-se ao trabalho. Para que, então, encher-lhes as cabeças com essas marafundas do actual programma? Demos aquillo de que têm necessidade nas luctas pela existencia, e teremos cumprido nosso dever.

Si quizerem, porem, aprofundar-se mais no estudo, ahi está o programma do curso complementar para satisfazer-lhes os desejos (Opinião. In: Revista de Ensino, fevereiro de 1905, n. 05, ano III, p.536-537).

Por último, na apreciação de Francisco Luz, a duração do curso primário devia ser não de 4, mas de 5 anos. Só assim se evitaria que, no último ano, fossem acumuladas as matérias, o que trazia inconvenientes ao ensino. Dirigindo-se aos legisladores, os conselhos do professor tinham como intuito convencê-los a "organisar programmas desenvolvidos, de accôrdo com os progressos da civilisação actual nos apresenta e não de restringil-os, prejudicando a infancia, que precisa de uma boa porção de conhecimentos para comprehender as maravilhas que a sciencia diariamente lhe põe diante dos olhos" (Consulta ao professorado. In: Revista de Ensino, abril de 1905, n. 01, ano IV, p.626).

À época da publicação dos textos acima aludidos, incluindo-se aqueles que reproduzem as conferências de Carlos Escobar - estava em vigor, nas escolas-modelo e nos grupos escolares, o programa de ensino aprovado pelo Decreto n. 1217, de 29 de abril de 1904. Ademais, era recente a diminuição, de 5 para 4 anos, do curso desses dois tipos de escolas primárias (Lei n. 930, de 13 de agosto de 1904). Importa lembrar ainda que as escolas isoladas não possuíam um programa de ensino próprio, mas o Decreto n. 1239, de 30 de setembro de 1904, impôs a equiparação de tal programa para as mesmas, as escolas-modelo e os grupos escolares. No tocante às opiniões em torno do curso primário e dos programas de ensino, é possível observar que Carlos Escobar e Francisco Luz aventavam, respectivamente, a ampliação do curso para 7 e 5 anos, na medida em que os 4 anos em que ele estava organizado seriam insuficientes para a execução dos programas de ensino por eles formulados. Na direção contrária, o professor Ernesto Lopes da Silva propugnava a redução do curso primário para 3 anos - no caso das escolas isoladas e das escolas reunidas utilizava o termo "graus" - e, conseqüentemente, dos programas de ensino. Assim, poucas deviam ser as 
matérias ensinadas em qualquer que fosse a modalidade de escola, no que coadunava com o professor Izidro Denser. Silva estabelecia, contudo, uma diferenciação: as escolas isoladas e as escolas reunidas deviam seguir o mesmo programa de ensino, mas apenas no " $3^{\circ}$. grau" das primeiras era preciso um menor desenvolvimento do que se ensinaria no $3^{\circ}$. ano dos grupos escolares. O professor Emilio A. Ferreira também julgava como necessários programas de ensino distintos para as escolas isoladas e para os grupos escolares. Ao primeiro tipo de escola, estava reservado o curso preliminar de 2 anos, primeira etapa do ensino primário. Já os grupos escolares deviam oferecer o curso complementar de 3 anos, mas apenas para quem se habilitasse no curso preliminar. Por fim, vale frisar que Escobar não concordava com a criação de programas de ensino específicos para os grupos escolares e para as escolas isoladas.

Ainda no que concerne à remodelação dos programas de ensino, Arthur Breves, inconformado com aquele que os grupos escolares foram obrigados a executar a partir do Decreto n. 1281, de 24 de abril de 1905, advogava a divisão do curso neles ministrado em dois momentos. O primeiro deles, denominado de preliminar ou primário, duraria 3 anos e dele estariam encarregadas as professoras. O programa de ensino incluiria a leitura elementar, corrente e expressiva, e exercício de interpretação; escrita, inclusive a caligrafia; aritmética: quatro operações sobre inteiros, idéia geral de frações ordinárias e sua representação por escrito; lições de coisas; desenho elementar e canto por audição. Por sua vez, o segundo, formado pelo ensino complementar ou integral, seria completado em 4 anos e dele ficariam responsáveis três professores, tanto na seção feminina quanto na masculina. O programa abrangeria as seguintes matérias: $1^{\circ}$. ano - Português; aritmética até proporções e suas aplicações; álgebra até equações do $1^{\circ}$. grau e problemas $/ 2^{\circ}$. ano - Generalidades da geometria, aplicações; geografia geral e do Brasil; cosmografia / $3^{\circ}$. ano - Noções de física, química, botânica, zoologia e fisiologia / $4^{\circ}$. ano - História geral e do Brasil; noções de economia política e instrução cívica (O programma nos grupos escolares. In: Revista de Ensino, maio de 1906, n. 06, ano IV, p.835-837). A comparação do que previa a legislação escolar com o programa de ensino concebido por Breves mostra que, além da extensão do curso de 4 para 7 anos, outra diferença era a inclusão, pelo autor, de matérias como Noções de economia política, inexistentes no programa de ensino de 1905. Por outro lado, outras, como Trabalhos manuais e Ginástica, que deviam ser ensinadas nos grupos escolares, não foram mencionadas por Breves. 
Tanto quanto os professores, os inspetores escolares também não se inibiam em apresentar suas propostas do que deviam ensinar as escolas primárias. Tecendo referências ao programa de ensino instituído pelo Decreto n. 1217, de 29 de abril de 1904, a ser seguido pelas escolas-modelo, pelos grupos escolares e pelas escolas isoladas, Antonio Morato de Carvalho indagava: "Para que tanta exigencia? O ensino deve ser regulado, não por sua quantidade, mas por sua qualidade. 'Ler, escrever e contar', como diziam os antigos, é o sufficiente para as creanças do $1^{\circ}$. anno e para as que, em obediencia á lei da obrigatoriedade, tiverem que frequentar a escola" (Anuários do Ensino de 1910-1911, p.150-151). Na perspectiva do inspetor, portanto, cabia limitar o elenco de matérias ensinadas no $1^{\mathrm{o}}$. ano, qualquer que fosse o modelo de escola primária. Já Antonio Alves Aranha era partidário da diferenciação dos programas de ensino, sendo que esses deviam ser adaptados às necessidades do meio no qual a escola estava localizada. Nas áreas agrícolas, por exemplo, ela funcionaria em dois turnos, sendo que o primeiro seria para as crianças que auxiliassem seus pais na lavoura e o segundo para o restante dos alunos. Por outro lado, nos centros populosos, onde trabalhavam os pequenos operários, os cursos noturnos eram aqueles vistos como a única solução, mas deviam se restringir ao ensino do ler, do escrever e do contar, num período de duas horas por dia.

Crítico contumaz da adoção, nas escolas isoladas, do programa de ensino das escolas preliminares de 1893, o inspetor escolar Francisco Pedro do Canto indicou, em dois relatórios produzidos em 1900 (Ordem 7025) e em 1902 (Ordem 6932), como deveria ser reorganizado o ensino primário. Ao seu ver, as escolas primárias deviam ser divididas em rurais e urbanas, sendo elas, respectivamente, mantidas pelo município e pelo Estado. Além disso, as segundas seriam subdivididas em dois graus, tanto para um sexo quanto para outro, na proporção de duas escolas do $1^{\circ}$. grau para uma do $2^{\circ}$. grau. Nos lugares onde a população escolar fosse insuficiente para a existência de uma escola para cada sexo, seria criada uma escola mista. Canto esclarecia ainda que o programa de ensino das escolas do $1^{\circ}$. grau devia ser mais simples do que o daquela do $2^{\circ}$. grau, "de modo a estabelecer uma escala gradativa entre essas escolas e os grupos escolares nos quaes deve continuar em execução o programma de 1893, com pequenas modificações" (Ordem 7025). Por fim, segundo ele, as escolas rurais deveriam dedicar-se, uma vez por semana, ao ensino prático dos primeiros rudimentos de agricultura. Para tanto, era preciso que elas tivessem um terreno próximo, bem como ferramentas apropriadas. 
A idéia de que as escolas primárias instaladas nas zonas rurais deviam ter como meta a introdução das crianças no mundo do trabalho agrícola foi retomada com força a partir do final dos anos de 1910. Na ocasião, o problema da educação dos filhos do caboclo era considerado pelos inspetores escolares como de difícil solução, em decorrência da forma como esses profissionais concebiam aquelas crianças. Um deles, José de Camargo Couto, propôs a implantação de internatos rurais, os quais consistiriam em "verdadeiras escolas profissionais, onde os nossos caipirinhas se affizessem a um trabalho methodico, moderado. Essa iniciação, ministrada num periodo de grande plasticidade psychologica, seria o unico meio de combater a indolencia, que é o traço mais caracteristico do nosso caboclo" (Anuários do Ensino de 1918, p.839). O isolamento das crianças nas escolas seria também o meio mais eficaz para afastá-las não apenas dos preconceitos dos pais, tidos como uma má influência para elas, como ainda do hábito do alcoolismo, que estaria se espalhando pelo interior como uma "verdadeira praga" (Anuários do Ensino de 1918, p.839). Não por acaso, essas instituições contribuiriam para que os alunos aprendessem noções práticas de higiene.

A imagem negativa do caboclo e de seus descendentes também pode ser vislumbrada no relatório assinado pelos inspetores escolares José Carlos Dias, Aristides José de Castro e Joaquim Luiz de Brito. Nesse caso, aquela é utilizada também para justificar a necessidade de se devotar cuidados com a saúde dos habitantes do campo, a fim de prepará-los para o trabalho:

\footnotetext{
O nosso caboclo é, em geral, um ser aphatico, indolente e fatalista. Não tem vontade propria; deixa-se levar por quem lhe ganha sympathias, ou por quem, por actos de energia, sobre elle conquista ascendencia. É conservador e rotineiro. Sem ambição, trabalha apenas o necessario para prover a sua parca mantença, habitando casebres onde escasseia todo e qualquer conforto, alimentando-se mal e descurando em absoluto do tratamento da propria saúde e da sua prole, como bem demonstra o elevado numero de crianças doentes que frequentam as escolas. Entendemos, por isso, que o caboclo deve merecer a mais carinhosa attenção dos poderes publicos, no sentido de o transformarem em um ser sadio, forte, apto para o trabalho (grifos meus; Anuários do Ensino de 1918, p.723).
}

Outro inspetor escolar que sugeria uma feição profissional para a escola destinada às crianças residentes nas áreas rurais é José Monteiro Boanova. Em sua perspectiva, essa devia “obedecer a uma organização especial, accomodada á indole do caboclo, de uma região, e á sua profissão futura" (Anuários do Ensino de 1918, p.783-784). Para isso, ele recomendava a generalização, em todo o Estado, do que era ministrado no Aprendizado Agrícola "Bernardino de Campos", dirigido por Lourenço Granato em Iguape. No programa de ensino desse estabelecimento, executado ao longo de 2 anos, estariam incluídas, além das matérias comuns 
a outros tipos de escolas primárias - Leitura, Caligrafia, Noções de Geografia, História Pátria, Aritmética, até proporções e Desenho linear - aquelas ditas primordiais para a preparação prática do lavrador. Eram elas: Botânica Agrícola (noções de anatomia e morfologia); Zoologia Agrícola (noções gerais sobre os animais domésticos); Agrimensura; Agronomia Geral; Prática agrícola; Botânica agrícola (noções de fisiologia); Agricultura em geral; Elementos de Zootécnica.

Na década de 1920, a constatação de que os programas de ensino das escolas rurais deviam ser diferenciados ainda persistia entre os profissionais da educação. Dessa vez, no entanto, aquela partiu dos colaboradores dos periódicos educacionais. Arnaldo Barreto, por exemplo, avaliava como imprescindível que as escolas isoladas rurais tivessem uma finalidade utilitária. Nesse sentido, ele descrevia as atividades com as quais as crianças poderiam se envolver, como a cultura de flores, de verduras, de plantas frutíferas, com todas as espécies de enxertos; a incubação mecânica de ovos; a criação de pintos, de abelhas e de bichos da seda. Através dessas ocupações práticas, a escola despertaria nos alunos o gosto pela vida rural, ou seja, desenvolveria suas "aptidões, talvez latentes, com proveito para si proprios e para a zona da respectiva localização" (Escolas ruraes. In: Revista Escolar, janeiro de 1925, n. 01, ano I, p.54). Também na ótica de João Miguel Amaral, autor do artigo A escola rural e a agricultura (In: Educação, setembro de 1929, n. 03, ano VIII, p.349-352), a escola rural, além dos saberes elementares, devia oferecer o ensino das noções gerais de agricultura e de indústria agrícola, além dos modernos métodos de trabalho. Mediante a experiência e a observação, os futuros agricultores aprenderiam a aproveitar melhor a fertilidade das terras, a preparar os produtos mais adequadamente e a conquistar os mercados.

Divergindo dos sujeitos escolares acima mencionados que defendiam que a escola rural devia possuir um caráter profissional, o inspetor escolar Mauricio de Camargo era a favor de que elas, caso instaladas em regiões onde não houvesse a presença estrangeira, simplesmente alfabetizassem as crianças. Claramente preconceituoso em relação ao caboclo, ele ressaltava que, nas zonas onde esse pudesse manter contato com o imigrante, o exemplo iria, gradativamente, tornando o primeiro não apenas mais educado, como mais consciente do valor da escola. Não obstante, nos locais onde o

clima e a fertilidade das terras não attrahem o estrangeiro, tudo se conserva quasi que no mesmo pé em que estava ha um seculo; continúa na mesma rotina por falta de quem tenha esclarecimentos ou iniciativas.

O programma mais proprio para estes centros atrasados e por isso mesmo mais pobres, deve ser o mais resumido possivel. O professor tratará de alphabetizar as crianças, dando aulas para o maior numero que comportar a sala, ou subdividindo-as, 
mesmo em duas turmas, se fôr necessario (Anuários do Ensino de 1918, p.770).

Como é possível depreender, foram inúmeras as propostas de reformulação dos programas de ensino das escolas primárias. Mas se os seus autores não entravam num consenso quanto ao que deviam ensinar os grupos escolares, eles, à exceção de Carlos Escobar, concordavam que era indiscutível que às escolas isoladas cabiam oferecer um ensino diferenciado daqueles, fosse pela menor duração do curso primário, fosse pelo programa de ensino mais reduzido ou fosse ainda pelo perfil profissional que elas deviam ter. Assim, a dificuldade em apontar quem eram os responsáveis pela produção dos programas de ensino é recompensada pela possibilidade de observar as disputas envolvendo os projetos culturais traçados para as escolas. O programa de ensino, pois, longe de constituir uma inocente e neutra seleção de saberes escolares, era fruto de um processo de construção social, do qual participavam vários sujeitos escolares com interesses nem sempre convergentes (Goodson, 1995; Silva, 1996). Por isso, o programa de ensino oficial pode ser interpretado como "o clímax de um longo e contínuo conflito" (Goodson, 1995, p.24). Enquanto um território contestado, esse elemento central da cultura escolar é a expressão clara da luta pela manutenção ou pela superação das divisões sociais (Silva, 1996). Não por acaso, no período aqui estudado, ele foi utilizado como um mecanismo de diferenciação social (Goodson, 1995). Isso porque - ao persistir, no decorrer da Primeira República, "principalmente entre os especialistas e encarregados do campo da educação, a idéia de que o homem do campo não precisava de escolaridade nos mesmos níveis que os da cidade, mais "necessitado' dela" (Demartini, 1989, p.12) - pouco era realizado em termos de se criar oportunidades de ascensão social ao primeiro. De fato, se não é possível determinar em quais instituições de ensino trabalhavam os professores consultados pela Revista de Ensino, sabe-se, por outro lado, que tanto a maioria dos colaboradores das revistas pedagógicas, quanto os inspetores escolares ocupavam posições de destaque no campo educacional. Muito mais do que os dois primeiros, todavia, eram os inspetores quem recorriam, em seus relatórios, a "laboriosas operações discursivas que emitiam juízos de valores, analisavam, criticavam e, assim, induziam e influenciavam" (Resende; Faria Filho, 2001, p.84). Esses profissionais, dessa forma, estavam cientes de que a importância de seu cargo lhes conferia prestígio e poder para persuadir os demais sujeitos sociais de que eram fundamentados seus pontos de vista sobre o que deviam aprender as crianças que freqüentavam as escolas rurais. Ao que dependesse dos inspetores escolares, em suma, o destino social dessas parcelas da população paulista esquecidas pelo poder público já estava selado, isto é, elas deviam permanecer no campo, evitando-se, por 
conseqüência, o tão temido êxodo rural. Entende-se, assim, as palavras de Bourdieu (2004) sobre o "campo". Para o autor, nele

os adversários lutam para impor princípios de visão e de divisão do mundo social, sistemas de classificações, em classes, regiões, nações, etnias etc., e não cessam de tomar por testemunho, de algum modo, o mundo social, de convocá-lo a depor, para pedir-lhe que confirme ou negue seus diagnósticos ou seus prognósticos, suas visões e suas previsões (2004, p.23-24).

Enfim, os relatórios escritos pelos inspetores escolares, ao reiterarem a necessidade de diferenciação entre os programas de ensino das escolas isoladas e dos grupos escolares, consistem em materiais privilegiados para se comprovar o objetivo das políticas públicas educacionais daquele período: a conservação das desigualdades sociais, para a qual era crucial impedir o público das primeiras de ter o acesso aos mesmos saberes escolares lecionados nos segundos.

\subsection{As distâncias entre o que determinavam os programas de ensino e o que se ensinava nas escolas primárias}

Se a publicação, em 1887, de um programa de ensino enriquecido e, logo, marcadamente diferente dos anteriores, significou uma profunda mudança na organização didático-pedagógica das escolas primárias, certo é que ela também trouxe muitas implicações para a prática docente. No texto intitulado Mestra Benedita ensina primeiras letras em São Paulo (1828-1858) (1997), Hilsdorf mostra como era estruturada a educação primária imperial, por meio do exemplo de Benedita da Trindade, professora de uma escola feminina na então Província de São Paulo. Responsável por ministrar aulas a 50 alunas de diferentes idades e níveis de adiantamento, Benedita recorria ao ensino individual, ou seja, cada uma delas recebia atendimento específico, conforme sua progressão nos estudos. Não havia, pois, o ensino simultâneo e seriado, inaugurado com a criação dos grupos escolares. Ao contrário, as matérias constantes dos programas de ensino vigentes ao longo dos 30 anos em que a mestra lecionou eram apresentadas às meninas de acordo com a seguinte seqüência:

ler o ABC; ler sílabas; ler sílabas e principiar a escrever; soletrar cartas e começar a escrever; ler correntemente cartas, livros e escrever mal; ler bem, escrever mal, contas de somar; ler bem, escrever mal, contas de diminuir; ler bem, escrever mal, contas de somar e tabuada; ler bem, escrever bem, contas de diminuir e gramática; 
ler e escrever bem, contas de multiplicar; ler e escrever bem, contas de multiplicar e gramática; 'ler bem, escrever, contar, gramática, a doutrina cristã, o Catecismo Histórico de Fleury, a Constituição do Império e outras miudezas que por curiosidade lhe ensinei, bem como os princípios gerais de geografia' (Hilsdorf, 1997, p.103).

Para profissionais acostumados a conduzir seu trabalho desse modo, lidar, pela primeira vez, com um programa de ensino extenso, tal como era aquele de 1887, consistia num grande desafio, que dificilmente poderia ser vencido. Com efeito, o relatório da professora Maria Eugenia Nunes, datado de 1891, ilustra bem que, ao ver deles, o programa era impraticável e, por isso, urgia sua modificação:

Quanto ao ensino propriamente dito, peço licença para ponderar a V. $\mathrm{S}^{\mathrm{a}}$. que o programma do ensino primario, pelo regulamento em vigor, abrange dez materias, alem da educação civica e das lições com observação espontanea. Ministrar o ensino de tantas materias em uma escola tão regularmente frequentada, como é a que dirijo, si não é tarefa impossivel, é uma incumbencia legal que jamais poderá dar resultados satisfactorios. Nem a aptidão e criterio do professor, nem o seu mais decidido amor pelo ensino da mocidade poderão preencher uma lacuna da lei, que forçosamente deve ser reformado, de modo que seja praticavel. A lei não é feita para ser lida, mas para se executar. Parece, pois, uma necessidade, a bem da instituição, que se faça um programma de ensino mais modesto, porem exeqüível (Ordem 4931) ${ }^{97}$.

Convém recordar que à época, a escola preliminar sob a responsabilidade de Nunes ainda guardava as mesmas características das antigas escolas régias. A partir de 1894, quando os grupos escolares começaram a ser espalhados pelo território paulista, as condições de trabalho nas escolas preliminares - denominadas oficialmente de escolas isoladas a partir de 1904 - não sofreram qualquer alteração. Com isso, a amplitude dos programas de ensino das escolas isoladas, intensamente criticada pelos inspetores escolares antes do início do processo de diferenciação daqueles, continuou a ser um obstáculo para o profisssional que não podia usufruir da forma como eram organizados os grupos escolares. Não por acaso, a professora Brasilia Ilidro da Silva, da Escola preliminar do sexo feminino do $9^{\circ}$. distrito da Capital, assinalava que havia dado início ao "ensino das materias acrescidas no novo programma de ensino, das Escolas Preliminares, (...) encontrando, porem, difficuldades no ensino d'ellas pela accumulação de 4 annos para uma só professora lecionar" (01 de novembro de 1894). Ademais, referindo-se ao programa de ensino das escolas preliminares de 1894, o professor Izidro Denser, da escola pública do $3^{\circ}$. distrito da Capital, explicava em seu relatório a razão da impossibilidade de se executá-lo fielmente: "Quanto à distribuição das materias, foi observado, em parte, o programma que vem no Regimento Interno sob o annexo $\mathrm{n}^{\circ}$. 1 , porque cumpril-o à risca é absolutamente impossivel numa escola isolada, pois é certo que tal

\footnotetext{
${ }^{97}$ Todos os relatórios escritos por professores foram encontrados na lata de Ordem 4931.
} 
programma foi organisado de accordo com o das escolas-modelos e só servirão para os grupos escolares, onde ha divisão do trabalho" (01 de novembro de 1895). O que afligia tanto Silva quanto Denser, em suma, era o fato de que, se nas escolas graduadas cada professor devia ensinar apenas as matérias e os conteúdos correspondentes ao ano para o qual ele lecionava, nas escolas isoladas, em virtude de ter de enfrentar, sozinho, a heterogeneidade de faixas etárias e de fases de adiantamento dos alunos, o mestre era obrigado a ministrar todo o programa de ensino. A propósito, não se tratava de mera coincidência o fato de que Denser, anos depois, escreveu, em texto veiculado na Revista de Ensino, sobre a necessidade de simplificação dos programas de ensino das escolas primárias.

Mas o período em que teve de cumprir vastos programas de ensino não foi árduo para o corpo docente das escolas isoladas apenas devido à inexistência do ensino homogêneo. A esse fato somava-se a morosidade com que o poder público dotava as escolas dos instrumentos mais essenciais, até mesmo o próprio programa de ensino. A professora Georgina C. da Silva, da Escola preliminar do Campo Mauá, registrou em 01 de junho de 1894, que suas alunas foram classificadas "segundo o programma do ensino, annexo ao regimen interno das escolas do Regulamento de Instrucção de 1887, visto ainda não termos do actual Regulamento de 1892, faltando portanto, muitas columnas para as materias accrescidas". Essa queixa pelo não recebimento dos programas de ensino foi feita também pelo professor Joaquim Lopes da Silva, em relatório de 01 de novembro de 1893: "Para a confecção do mappa, agora apresentado, serviu-me de base o Regulamento de 22 de Agosto de 1887 e não o de 30 de Dezembro do anno passado, visto como este, modificado pela nova refórma da ultima sessão legislativa, não foi ainda distribuido, ao que parece, aos professores do Estado". Curiosamente, em relatório também datado de 01 de novembro de 1893, o professor Alfredo Bresser da Silveira, da Escola do bairro da Bela Cintra, informava que obedecia à “disposição do art. $135 \S 14$ do regulamento de 30 de Dezembro de 1892”.

Essa mesma discrepância em relação ao programa de ensino que os professores buscavam seguir pode ser verificada em dois diferentes relatórios referentes ao dia 01 de novembro de 1894. Um deles é o do professor Luiz Cardoso Franco, da Escola preliminar do $11^{\circ}$. distrito da Capital: "Observando o art. $135 \S 14$ do regulamento de 27 de Novembro de 1893, venho, ainda que resumidamente, trazer ao vosso conhecimento o estado da escola a meu cargo (...). As materias leccionadas são as de que trata o art. 62 do regulamento vigente". Já a professora do $11^{\circ}$. distrito do Município da Capital, Izabel de Serpa e Souza, assim salientava: "De acordo com o atual regimento interno das escolas, estas alumnas acham-se 
divididas pelos 4 annos e suas series, bem como recebem a instrucção de conformidade com o programma do referido regimento e seus anexos". O Regimento Interno mencionado pela professora é aquele aprovado pelo Decreto n. 248, de 26 de julho de 1894. Enfim, ao que tudo indica, em função da falta de distribuição às escolas dos programas de ensino, num mesmo período do ano não havia uniformidade no que dizia respeito àquele tomado como base pelo professor para o seu trabalho.

Afora os programas de ensino, os professores reclamavam também da ausência de materiais didáticos para o ensino de determinadas matérias, a despeito do que previa a legislação escolar: “Art. 50. - Cada escola preliminar, além de uma área bastante espaçosa para recreios e exercícios físicos, terá uma sala apropriada para os trabalhos manuais e os objetos e aparelhos necessários para o ensino intuitivo, para o da geografia, do sistema métrico e da ginástica" (Lei n. 88, de 08 de setembro de 1892). Cabe lembrar que a adoção do método intuitivo no ensino primário exigia o fornecimento às escolas dos mais variados utensílios, tais como globo terrestre, mapas, quadros de história natural, cadernos de caligrafia, cartões para a Leitura e para a Geometria, tabuinhas para trabalhos de modelagem, aparelhos de ginástica, sólidos com formas geométricas, entre outros (Souza, 1997; Americano, 2004). O mesmo relatório da professora Maria Eugenia Nunes antes mencionado mostra que problemas no provimento material se tornaram uma das principais justificativas dos docentes para a não obediência total aos programas de ensino:

A lição de cousas, cuja utilidade e vantagem hoje ninguem mais põe em duvida, exigem, entretanto, para que possam ser ministradas com proveito, que as escolas sejão dotadas dos necessarios objectos destinados a observação e ao estudo dos alumnos. Nem é possivel que sem os objectos essas lições possam ser ministradas, pois que então ellas perderiam a sua natureza e principalmente a sua vantagem e utilidade, devendo-se antes chamar de lições de ideias do que lições de couzas. É de urgente necessidade que as escolas recebam esse grande melhoramento, dotando-selhes com os objectos e utensis necessarios para as lições de couzas. O ensino de outras materias, tal como a Geographia, tambem deve ser ministrado nas escolas com todos os melhoramentos pedagogicos até hoje conhecidos (grifos da autora).

Maria Marcolina Pinheiro e Prado, professora da Escola pública do sexo feminino do Bairro do Telégrafo, também pontuava que ainda era "lento e de pouca firmeza o estudo de algumas materias cujo ensino reclama, digo, exige mais do que outras os meios intuitivos para os quaes falta a esta escola o material mais necessario" (01 de junho de 1894). Já Elisa de Almeida, em relatório de 01 de novembro de 1894, afirmava que foram ensinadas a Leitura, a Caligrafia, a Aritmética, a Geografia, as Noções de ciências físicas, químicas e naturais, a Ortografia, a Moral e a Educação Cívica. No entanto, ela fazia uma ressalva: "Deixei de 
ensinar algumas materias do programma que o regulamento manda, devido a falta de material para esse fim". Por sua vez, nas palavras de Joaquim Lopes da Silva, professor da Escola pública da rua de Santa Efigênia $\left(12^{\circ}\right.$. distrito da Capital), para "a fiel observancia e aproveitavel desenvolvimento do programma preliminar é indispensavel que esta cadeira seja contemplada com o fornecimento não só da mobilia (...) como tambem de todo o material pedagogico, de que tem necessidade, taes como globo e mappas geographicos, colleções de historia natural, quadros negros, etc" (01 de junho de 1895). Além disso, em relatório datado de 01 de junho de 1897, Beatriz Pereira Penna, assim pronunciou-se: "Aproveito a opportunidade para solicitar aos digneis auctorisar o funccionamento a esta escola, de dez bancos-carteiras, de um quadro negro e de mappas geographicos, objectos estes que se tornam indispensaveis á bôa organisação do ensino das materias cujo programma devo observar". Por fim, na opinião da professora Maria José Nogueira, sua escola

necessita de papeis, lapis, tintas, tinteiros, compendios de Geographia, Arithmetica, Portuguez, Desenho Linear, Licções de Cousas, (...) enfim tudo que é preciso afim de poder-se executar as materias do programma do Regimento Interno.

(...) Despida como se acha a cadeira dos meios necessarios, não é possivel, por melhor boa vontade que exista, executar com perfeicção o programma do Reg. na parte relativa ao ensino (21 de junho de 1897).

Tanto quanto a dotação material, também as instalações físicas das escolas preliminares eram motivo de queixa dos professores. Não obstante, mais uma vez, o respaldo legal, a precariedade daquelas era fator que impedia o ensino de certas matérias, especialmente da Ginástica. É o que denunciava o relatório da professora Maria Marcolina Pinheiro e Prado: "Cumpre-me dizer-vos que relativamente a disciplina da gymnastica não tenho podido pol-a em pratica por falta de espaço na sala da escola, já não falando do patio de recreio que não tenho absolutamente e cujo espaço seria o apropriado para marchas e mais exercicios gymnasticos”. Seu colega, Francisco de Assis Velloso, foi ainda mais categórico, ao atrelar o cumprimento dos programas de ensino à construção de edifícios escolares:

O professorado, em geral, está preparado para executar o programma de ensino, e mesmo acha-se animado a cumprir seu arduo dever, mas para isso é mister que haja predios para o funcionamento das escholas, porque as cazas em que actualmente estão localisadas, e que são pagas às expensas do professor, são a negação da hygiene e de todos os attributos a estabelecimentos de tal ordem! ${ }^{98}$

Para além das condições materiais, outra alegação dos professores para não se aterem às normas legais era a falta de habilitação profissional para o ensino de determinadas matérias,

\footnotetext{
${ }^{98}$ Não foi possível determinar as datas a que se referem os dois relatórios.
} 
principalmente Canto e Ginástica. À guisa de ilustração, Joaquim Lopes da Silva revelou em seu relatório, de 01 de novembro de 1891, que o "ensino de canto choral, bem como o de gymnastica, não foram ainda inauguradas nesta escola, (...) por não me julgar obrigado a leccionar essas materias”. Já Maria Marcolina Pinheiro e Prado informava que, à exceção "da musica, que não sou obrigada a ensinar, (...) tenho ensinado todas as materias prescriptas, quanto possivel segundo os meios escolares e as minhas forças (01 de junho de 1892). Por sua vez, Brasilia Ilidro da Silva comunicou, em 01 de junho de 1894, que o ensino da Ginástica ainda não havia sido iniciado por "não tel-a estudado e nem mesmo visto praticar na Escola Modelo, à qual ainda não me foi ordenado frequental-a". Por último, assim escreveu Georgina C. da Silva, da Escola preliminar do Campo Mauá: "se ainda não ensino gymnastica, a razão é não ter uma noção precisa, apezar de já ter frequentado umas 3 vezes a Escola Modelo o anno passado, não sendo bastante, mais vale a pratica que a theoria" (01 de junho de 1894).

Para eximirem-se de ensinar o Canto e/ou a Ginástica, os professores Joaquim Lopes da Silva, Maria Marcolina Pinheiro e Prado e Brasilia Ilidro da Silva recorriam ao que determinava o Artigo 31 da Lei n. 81, de 06 de abril de 1887, a saber, os "professores observarão desde já os programas de ensino primário dessa lei, não sendo, porém, obrigados a lecionar as matérias acrescidas para cuja disciplina não tenha sido habilitado" (apud Gallego, 2008). Isso porque tais matérias ainda não figuravam no programa da Escola Normal, "ainda que se anunciasse a coerência desse com o do ensino primário, a exemplo de canto coral e ginástica" (Gallego, 2008, p.214). Nesse sentido, a introdução dessas ditas modernas matérias no programa do ensino primário não foi acompanhada da necessária atualização dos cursos de formação docente. Por outro lado, o relato da professora Brasilia e o de Georgina sugerem que a observação, na prática, do ensino da Ginástica, era tida como fundamental para complementar o preparo insuficiente que receberam. Além disso, ambos os documentos permitem vislumbrar a atuação da escola-modelo como referência de funcionamento para as demais escolas primárias. Para finalizar, cabe destacar o depoimento da professora Izabel de Serpa e Souza que regia, ao que parece, uma escola intermédia, onde os professores eram aqueles habilitados de acordo com os regulamentos de 18 de abril de 1869 e de 22 de agosto de 1887 (Artigo 50 do Decreto n. 144-B, de 30 de dezembro de 1892). Desse modo, embora eles não fossem obrigados a ensinar as matérias acrescidas, das quais não tivessem exames (Artigo 57 do Decreto n. 144-B), a mestra decidiu submeter-se a esses, para tornar-se apta a seguir o programa de ensino das escolas preliminares: 
De acordo com o atual regimento interno das escolas, estas alumnas acham-se divididas pelos 4 annos e suas series, bem como recebem a instrucção de conformidade com o programma do referido regimento e seus anexos. É claro que tendo-me habilitado pela lei $\mathrm{n}^{\circ} .81$ de 6 de Abril de 1887 não prestei exame das materias acrescidas no novo regulamento; o desejo porem de satisfazer ao programma e de equiparar a minha escola tanto quanto possivel às escolas preliminares, levaram-me ao estudo dessas materias para assim poder ministrar às minhas alumnas uma instrucção equivalente à das supraditas escolas, como provei nos exames realizados a 12 de Dezembro (01 de novembro de 1894).

Se nas escolas não graduadas os professores encontravam empecilhos para a concretização dos programas de ensino, resta saber se nos grupos escolares esses profissionais se deparavam com menos percalços. No livro O calvário de uma professora (1927), a protagonista, Hermengarda, havia tido uma desagradável experiência com o diretor do primeiro grupo escolar no qual trabalhou, após 2 anos de exercício em escola isolada, ambos situados no interior do Estado: "Fazia-a soffrer o mais duro vexame, fiscalizando sem treguas o seu trabalho diario. (...) Tornava-a escrava do horario e programma escolar. Não lhe permittindo afastar-se deste uma linha, nem passar um minuto daquelle" (Dora Lice, p.56). Vale recordar que uma das funções do diretor era fiscalizar todas as classes durante o seu funcionamento (Art. $84 \S 1^{\circ}$. do Decreto n. 248, de 26 de julho de 1894), o que certamente incluía verificar se o professor seguia ou não o programa de ensino. Se era esse elemento da cultura escolar que expressava as nada modestas finalidades atribuídas a esse tipo de escola primária, recorrer a mecanismos de regulação da atividade docente foi o artifício encontrado pelo Estado para garantir que nada atrapalhasse a consecução desses objetivos. Para tanto, os próprios imperativos legais foram utilizados. Com efeito, o Decreto n. 1216, de 27 de abril de 1904, definia que o papel do professor era "ensinar todas as materias do programma legal, e apresentar ao director os motivos justificaveis quando não o possa fazer" (Art. $93 \S 4^{\circ}$.). Uma exigência como essa fazia com que os docentes dos grupos escolares almejassem a autonomia, tal como bem demonstra o que ocorreu com Hermengarda. Para seu alívio, o antigo diretor foi substituído por outro que, a despeito de sua posição hierárquica, sublinhava que iria tratar os professores

(...) como collegas e não como inferiores. Teriam em suas classes completa liberdade de acção. Dariam as suas aulas como lhes approuvesse, cingindo-se, todavia aos programmas, e respeitando os horarios até onde fosse possivel.

Não iria repreender um collega por se estender mais alguns minutos nesta ou naquella disciplina. (...) Quando entrasse em alguma classe, não suppuzessem que a iria fiscalizar. Não estava ali para isso (Dora Lice, 1927, p.64-65). 
Além da figura do diretor, outro dispositivo de vigilância e controle sobre o magistério primário era a inspeção escolar. Embora a visita às escolas isoladas também fizesse parte do trabalho dos profissionais dela encarregados, o difícil acesso àquelas tornavam raros os momentos em que se observava a obediência ou não do professor dessa modalidade de escola primária aos programas de ensino. Assim, o exercício docente realizado nos grupos escolares apesar de recompensado com salários mais elevados do que aqueles pagos aos mestres das escolas isoladas e aos das escolas reunidas - era o mais cerceado pelas autoridades escolares, fossem elas os diretores ou os inspetores escolares. Não à toa, a personagem Hermengarda comparava seu trabalho desenvolvido à época com o anterior: "Os dois annos de escola isolada foram o melhor tempo de minha vida como professora. Foi um trabalho suave. Não tinha tantos e tão exigentes chefes! Eu mesma dirigia a minha escola e o resultado final era sempre satisfatorio" (Dora Lice, 1927, p.99).

A ausência do cargo de diretor e a débil inspeção escolar não significavam, contudo, que o professor da escola isolada pouco se preocupasse com $o$ que ensinava aos seus alunos. Longe disso, eram as notas obtidas nos exames que determinavam o futuro de sua carreira, ou seja, o bom rendimento escolar atestava que o ensino ministrado foi eficiente e que, portanto, o professor merecia ser removido para os grupos escolares. Em suma, a "reprovação do aluno representava, em verdade, a condenação do professor" (Demartini, 1985, p.65). O exame, nessa perspectiva, tinha sentidos diferentes caso se tratasse das escolas isoladas e dos grupos escolares: se no primeiro tipo de escola ele era o indicador da qualidade do trabalho docente, no segundo ele era necessário para promover os alunos de uma série para a seguinte e, pois, traduziam o esforço desses (Gallego, 2003). Ademais, se não havia, nas escolas isoladas, a ação direta e incisiva dos diretores e dos inspetores escolares, as próprias avaliações serviam como instrumento de controle do Estado, ainda que sutil, no que se referia à conformidade dos mestres aos programas de ensino. A partir de 1910, as normas legais passaram a definir que os exames, tanto nos grupos escolares quanto nas escolas isoladas, deviam ser realizados não mais nos meses de maio, agosto e novembro, como ocorria desde 1904 até então, mas sim em abril, junho, setembro e dezembro (Gallego, 2003). Mais uma vez, são as vivências da professora Hermengarda que oferecem preciosos detalhes das práticas nas escolas isoladas, sendo que, dessa vez, elas aludem a esse importante componente da cultura escolar:

Os exames eram apertadissimos. Para cada disciplina, um examinador, escolhido entre as pessoas gradas do logar. Advogados, engenheiros, politicos graduados, tudo gente fina e de muito saber, mas que nada sabiam do pouco que podiam assimilar as frageis intelligencias das mimosas creaturinhas ali presentes. Era preciso eu intervir a cada momento e avisar que S. Excias. estavam fora do programma. Mesmo assim 
as pequenas respondiam com tal vivacidade e acerto, que a professora era continuamente felicitada. Findos os exames, era servida a obrigatoria mesa de doces, aos examinadores. (...) Decorrido o tempo que a lei exige, fui nomeada para grupo escolar (Dora Lice, 1927, p.99).

Embora a organização da escola isolada e aquela da escola graduada acabavam por configurar dois perfis distintos de professores, ambos, ao que indicam os relatórios de diretores de grupos escolares, padeciam de dificuldades semelhantes, no tocante à aplicação dos programas de ensino em seus respectivos estabelecimentos. Deve-se isso ao fato de que a carência de recursos materiais também atingia os grupos escolares, tal como o de Piracicaba, dirigido por Antonio de Mello Cotrim. Em 01 de novembro de 1897, ele notificava que, em relação à Modelagem, não pôde ser iniciado "o ensino desta disciplina, por causa da falta de taboinhas destinadas a servirem de mesa. Vieram apenas 100 pranchetas, que não chegam nem para o $1^{\circ}$. anno da secção masculina" (Ordem 7105). Um registro semelhante é feito por Eduardo José de Camargo, do Grupo Escolar "Dr. Cerqueira César”, de Paraibuna: "Tenho me esforçado, tanto quanto possivel, para recuar as difficuldades que surgem a cada passo no desenvolvimento das materias prescriptas pelo regimento interno: já pela falta de compendios, já pela falta de alguns accessorios adaptaveis ao ensino de trabalhos manuaes e modelagem" (01 de dezembro de 1899, Ordem 6818). Sete anos depois, o mesmo diretor voltou a abordar o tema, sinalizando que seus apelos anteriores não haviam sido atendidos. Conforme Camargo, o programa de ensino havia sido desenvolvido "tanto quanto possivel, excepto, porem, naquellas materias que demandam de certos apparelhos de que não dispõe o grupo, como por exemplo as que se referem a classificação de animaes, discripção do corpo humano e outras, cujas lições seriam mais proveitosas e sufficientemente ministradas com o auxilio de mappas adequados" (Ordem 6935). Outro exemplo pode ser adquirido através do relatório de 31 de dezembro de 1899, produzido por Raphael de Moraes Lima, do Grupo Escolar de Bragança:

O programma de ensino, que deixo de aqui transcrever, por parecer-me isso dispensavel, é o que consta do annexo n. 1 do Regimento Interno das escholas salvo as inevitaveis restricções, em relação álgumas de suas disciplinas, taes como: Musica, por falta de um piano ou orgão; Gymnastica, por falta de apparelhos; Trab. Manuaes, na secção masculina, etc. (grifos do autor, Ordem 6801).

Além da questão dos materiais escolares, outro ponto em comum era a inadequada formação docente para o ensino de matérias específicas. À guisa de ilustração, Benedicto Americo Brazileiro, diretor do Grupo Escolar "Gabriel Prestes", em Lorena, avisava que o "ensino foi o mais regular possivel, abrangendo quasi todas as disciplinas do programma", exceto "musica, exercicios militares e trabalhos manuaes (...) devido a falta de pessoal 
competentemente preparado para isso" (22 de dezembro de 1899, Ordem 6801). Em outro relatório, datado de 1906 e cujo diretor não foi identificado, embora escrito em nome do Grupo Escolar "Maria José”, é possível encontrar o mesmo argumento:

O programma foi mais ou menos bem executado com excepção das disciplinas musica e exercicios militares.

É que para as lecionar não bastam a dedicação e o esforço.

Para ambas as materias é necessario tambem um aprendizado especial, accrescendo ainda que para ensinar musica é necessario ter voz e saber executar ao piano os exercicios e córos.

Nem todos os professores possuem estes dotes, estas prendas, e dahi a grande difficuldade e às vezes mesmo impossibilidade de transmittir o ensino desta disciplina que, como os exercicios militares constituem materia do programma official (Ordem 6935).

Ao que parece, poucos anos após terem sido implantados, os grupos escolares ainda não dispunham de muitos professores normalistas ou complementaristas. De acordo com Genesio Braulio Rodrigues, diretor do Grupo Escolar "Dr. Esteves da Silva", de Ubatuba, todos aqueles que lecionavam em seu estabelecimento de ensino eram professores intermédios, o que o levou, para prepará-los convenientemente, a criar "um curso nocturno onde são ministradas noções geraes sobre todas as materias constantes do novo programma dos grupos escholares (...)" (01 de junho de 1897; Ordem 7034). Dados colhidos por Tanuri (1979) confirmam que, em 1897, era baixo o número de diplomados em todas as escolas primárias paulistas: entre as 2.397 escolas existentes, 1.335 delas estavam providas, sendo 320 preliminares, 371 intermédias e 644 provisórias. Assim, ao passo em que havia um grande número de professores interinos, isto é, examinados perante os inspetores de distrito, eram apenas 27 aqueles que um ano antes concluíram a Escola Normal. Ademais, em 1898, dos recém criados cursos complementares, saíram somente 41 professores primários (Tanuri, 1979). Por conta disso, o diretor do Grupo Escolar de Ribeirão Preto, cujo nome não foi localizado, acreditava que o tipo de formação do professorado impedia a efetivação do que prescrevia para seu cargo o Artigo 59 do Decreto n. 518, de 11 de janeiro de 1898, a saber, inspecionar e fiscalizar todas as classes durante o seu funcionamento, imprimindo ao grupo o regime e o método de ensino das escolas-modelo:

A seriação das materias do programma dos Grupos Escolares, que constitue, incontestavelmente, o grande centro propulsor do ensino nestes estabelecimentos, não póde ser adquirido e empregado com vantagem, por aquelles que não tenham frequentados as nossas escólas Complementares ou Normal, onde, a par do ensino theorico, existe uma aprendizagem, substanciósamente pratica, dos modernos processos, methodos, módos e meios de ensino. Do que fica dito, Vossa Excellencia concluirá quão difficil se torna, a esta Directoria, o cumprimento das disposições do artigo $59 \S 2^{\circ}$. do Regulamento de 11 de Janeiro de 1898. 
A exigência legal de que os grupos escolares fossem organizados tal como as escolasmodelo incitou a solicitação de Martinho Nogueira, diretor do Grupo Escolar de Tatuí:

Desde a epocha em que esta directoria alcançou do Governo licença para frequentar as Escolas Modelo da capital, observa-se neste Grupo Escolar, com pequenissimas modificações adaptadas ao meio, o programma da Escola Modelo Caetano de Campos, annexa á Escola Normal da Capital. Não tem sido improficuos os trabalhos dos professores desde que se começou a por em execução o programma citado (01 de junho de 1897; Ordem 7105).

Possivelmente, o ato de Nogueira foi baseado no Artigo 118 do Decreto n. 248, de 26 de julho de 1894, segundo o qual aqueles que lecionavam na Capital deviam freqüentar, ao mínimo uma vez por semana, as aulas das escolas-modelo, para poderem aplicar em suas escolas os métodos de ensino ali empregados. Após "um anno de tal frequencia, os professores acima referidos poderão restringir o numero de suas visitas ás escolas-modelo, frequentando-as apenas uma vez por mez, afim de acompanharem os progressos realizados" (Art. $118 \S$ único).

Se os professores preliminares e os diretores de grupos escolares reclamavam que a deficiente dotação material prejudicava o acompanhamento integral dos programas de ensino, será que os inspetores escolares concordavam com ambos? Em alguns relatórios, é possível encontrar profissionais que reconheciam que, sem solucionar tal problema, a submissão à norma era injustificável. O inspetor do $3^{\circ}$. distrito escolar, por exemplo, assim escrevia em 1896:

Dependendo da capacidade do professor e dos recursos materiaes essenciaes ao exercicio do magisterio, na maior parte das escolas do districto não seguem os professores o programma official. Sobra-lhes, todavia, boa vontade para executal-o, e cumprirão satisfactoriamente esse dever logo que disponham dos recursos de que necessitam (Ordem 7034).

Mais de uma década depois, a questão ainda não havia sido resolvida. Ao menos é o que observava o inspetor escolar Antonio Morato de Carvalho:

grande é ainda o numero de escolas que não recebem, ha longos annos, fornecimento algum de moveis, livros didacticos, etc. Emquanto não estiverem todas ellas convenientemente installadas e providas do material preciso, não poderá o inspector escolar exigir razoavelmente dos professores a observancia das disposições regulamentares e as do programma (Anuários do Ensino de 1908-1909, p.11). 
$\mathrm{Na}$ mesma época, Aristides de Macedo também entendia que, para que o ensino primário pudesse produzir "os resultados que delle se esperam, é preciso attender-se ao melhoramento das condições pedagogicas das escolas. Faltando estas, por melhores que sejam os professores, os programmas e os methodos de ensino não preencherão o seu fim" (Anuários do Ensino de 1908-1909, p.22).

Embora se sensibilizassem com os embaraços decorrentes da precária infra-estrutura material que os professores tinham de administrar no dia-a-dia das escolas, os inspetores escolares não deixavam de apontar a falta de uniformidade verificada nas escolas por eles visitadas. A passagem abaixo, retirada do relatório do inspetor escolar Antonio Rodrigues Alves Pereira, datado de 31 de dezembro de 1899, ilustra com clareza que, na perspectiva deles, tanto nas escolas-modelo e nos grupos escolares, quanto nas escolas isoladas, a desobediência aos programas de ensino era patente. É necessário frisar, todavia, que, no caso dessa terceira modalidade de escola, se atribuía tal fato à inexeqüibilidade do programa das escolas preliminares (1894) que essa seguia, tal como adiantado no capítulo anterior:

Podemos considerar existentes no estado tres typos principaes de organização escholar: 1) Escholas Modelo e grupos; 2) Escholas reunidas; 3) Escholas isoladas.

O $1^{\circ}$. typo é incontestavelmente o que mais serviços presta e ha de prestar ao ensino, mas em relação aos grupos que são os que mais servem ao povo, propriamente dicto, existe uma verdadeira confusão relativamente ao programma seguido. Em uns as materias do curso preliminar são distribuidas por 5 annos de estudos, em outros por 4 e ha, ainda muitos que sacrificam diferentes materias do curso, ou por serem consideradas pelos professores como inuteis, ou por difficuldades do ensino; e finalmente, ha grupos que, ou deixando de lado parte do programma official ou seguindo-o, leccionam, alem disso, materias que delle não constam.

A uniformização dos programmas para grupos escholares é a meu ver uma necessidade urgente.

(...) $\mathrm{O} 2^{\circ}$. typo é um enxerto que se fez na nossa organisação escholar e que, no entanto, longe de prestar serviços, traz ao ensino difficuldades, annullando os esforços dos professores.

$\mathrm{O} 3^{\circ}$. typo é da organisação mais commum e o que presta muito bons serviços nas zonas cuja densidade de população não permitte o funccionamento de grupo escholar. (...) É rarissima a escola que segue o programma official e, diga-se com franqueza, o das escholas preliminares só pode ser praticavel com difficuldade, nas escholas que tiverem adjuncto (grifos do autor; Ordem 6818).

Também do ponto de vista do inspetor escolar Francisco Pedro do Canto, no que dizia respeito às escolas isoladas e aos grupos escolares, não havia

uniformidade no ensino. Cada uma escola tem seu programma, seu methodo, seu regimen differente. Em uma os alumnos são classificados de um modo, em outras de outro. Todas seguem processos de ensino differentes uns dos outros. O que observamos nas escolas isoladas nota-se tambem nos grupos escolares. Não ha duas escolas assim como não ha dous grupos, que se pareçam em sua organisação. Não 
temos um typo para as escolas isoladas nem para os grupos (janeiro de 1900; Ordem 7025).

Cabe lembrar que, assim como Pereira, também Canto considerava a amplitude do programa de ensino das escolas preliminares como a responsável pelas distâncias entre o que se prescrevia e o que ensinavam os professores das escolas isoladas. Em consonância com a avaliação dos dois inspetores, Virgilio Cesar dos Reis, em relatório produzido em 31 de dezembro de 1899, notava ser imperioso a redução de tal programa, já que, "extenso como é, a sua execução torna-se impraticavel, principalmente nas escolas isoladas. Da impraticabilidade do programma official resulta que cada professor ensina o que quer e como lhe parece, com prejuizo da uniformidade do ensino" (Ordem 6818). Essa diferença entre o que ensinavam escolas do mesmo tipo transparece ao se comparar dois relatórios de professores. Num deles, Georgina C. da Silva, da Escola preliminar do Campo Mauá, escrevia que ensinava, quanto ao trabalho manual, "somente o que diz respeito á costura, bordado, crochet, marca, etc, deixando dobramento de papel, e outras cousas por falta de tempo" (01 de junho de 1895). No lado oposto, Maria Marcolina Pinheiro e Prado, da Escola pública de $1^{\circ}$. grau do sexo feminino do Bairro do Telégrafo, ensinava mais do que exigia o Estado (01 de junho de 1896):

Além das materias prescriptas para o $1^{\circ}$. grau, continúo a ensinar, quanto a prendas domesticas, ás alumnas mais adiantadas, algumas prendas prescriptas para o $2^{\circ}$. e $3^{\circ}$. graus. Não acho nisto inconveniente, porque, já que algumas meninas podem fazel-o, devem aproveitar o tempo que é precioso.

Voltando ao relatório do inspetor escolar Antonio Rodrigues Alves Pereira, é possível entrever que ele constatava a existência, nos grupos escolares, de matérias desprezadas. Os próprios diretores desse tipo de escola, contudo, além daqueles das escolas-modelo, declaravam em seus relatórios que, com efeito, enfatizavam o ensino de certas matérias. $\mathrm{Na}$ Escola-Modelo "Maria José”, por exemplo, sua diretora, Eliza R. de Macedo - segundo dois relatórios por ela enviados (26 de dezembro de 1898 e 02 de dezembro de 1899) - solicitava dos professores um especial cuidado com o ensino da língua materna. Isso porque, em sua concepção, esse é "é essencialmente educativo, toca no desenvolvimento de todas faculdades intellectuaes e moraes e até na educação dos sentidos, pelo exercicio da palavra, do ouvido e da mão. Comprehende a escripta, a leitura, recitação, estylo, ortographia e a grammatica" (26 de dezembro de 1898 - Ordem 6926). Essa preocupação da diretora com a função educativa fica nítida em outro documento, no qual ela comentou que buscava convencer os docentes de que o "ideal da escola primaria não é o de ensinar muito porem ensinar bem" (02 de dezembro 
de 1899 - Ordem 6926). Isso demonstra, mais uma vez, a idéia de que, no programa de ensino, a parte educativa devia prevalecer sob a instrutiva, como visto no capítulo anterior. Já o diretor do Grupo Escolar de Mogi das Cruzes, Firmino Ladeira, informava, em relatório datado de 20 de dezembro de 1899, que o programa de ensino seguido pelos professores era aquele anexado no Decreto n. 248, de 26 de julho de 1894. Ele acrescentava, porém, que sem prejudicar o ensino das demais matérias - havia sido dado maior desenvolvimento em algumas daquelas ensinadas no $2^{\circ}$. ano da seção masculina, quais sejam, a Leitura, a Caligrafia, a Ortografia, a Aritmética, uma vez que "muitos paes ou responsaveis pela instrucção de meninos não renovam as matriculas dos mesmos, desde que completem o curso de $2^{\circ}$. anno" (Ordem 6818). Já conforme José Carneiro da Silva, diretor do Grupo Escolar "Dr. Alfredo Pujol", de Pindamonhangaba, foram aproveitados "todas as noções imprescindiveis á vida practica, assim como os principios das differentes disciplinas applicaveis ao commercio, industria, agricultura, etc." (31 de dezembro de 1899 - Ordem 6819). Em outros termos, ele confessava que foi priorizado o ensino das matérias consideradas principais - Aritmética, Sistema Métrico, Escrita, Linguagem, Leitura, Geografia, História do Brasil - mas que as demais não haviam sido afetadas. Por sua vez, de acordo com o relatório do diretor do Grupo Escolar de Ribeirão Preto ${ }^{99}$, de 05 de janeiro de 1902, nesse estabelecimento foi recomendado aos professores "que empregassem todo o desvelo e esforço no ensino de linguagem, arithmetica, geographia e educação civica" (Ordem 6932). Outro diretor, Ayres Amancio de Moura, do Grupo Escolar "Cel. Domingues de Castro" também sublinhava, em 1906, que, sem qualquer conseqüência para o restante do programa de ensino, uma atenção especial foi destinada ao ensino da Aritmética e da Linguagem. A justificativa para tal privilégio foi a de que, "sendo pobre a quase totalidade dos alumnos de nossos estabelecimentos primarios, onde a sua educação se encerra, é de conveniencia por não aspirarem frequentar outras escolas de ensino mais dilatado, provê-los de maior cabedal de conhecimentos de materias de uso constante" (Ordem 6935). Com um argumento semelhante, João Batista de Brito, diretor do Grupo Escolar "Prudente de Moraes", assinalava em seu relatório que - não pela preferência, mas sim pela

necessidade de preencher inteiramente os fins da escola popular, - deu-se melhor e mais completo desenvolvimento ao estudo das disciplinas fundamentaes - Leitura, Escripta e Calculo. Assim é preciso porque muitos dos alumnos que frequentam as nossas escolas publicas ficam sem outro preparo, considerando-se, com que nellas aprendem, aptos para encetarem as luctas da vida (01 de dezembro de 1906 - Ordem 4980).

\footnotetext{
${ }^{99}$ Seu nome não foi identificado.
} 
Era clara, portanto, a preferência dos diretores dos grupos escolares e também da diretora da Escola-Modelo "Maria José" pelas matérias tidas como fundamentais para a vida prática, já que, ao ver deles, se tratavam de escolas com uma feição popular. Por isso, em certos casos, eles chegavam mesmo a propor mudanças nos programas de ensino, como o fez Frantino Ferreira Guimarães, em 06 de dezembro de 1906: "seria conveniente substituir, no programma do $4^{\circ}$. anno feminino, as noções de Educação Civica pela Educação Domestica, visto trazer o ensino desta disciplina maior vantagem para a familia e para a sociedade" (Ordem 4980). Outro diretor que sugeriu alterações foi o do Grupo Escolar "Cel. Vaz", de Jaboticabal, em relatório de 15 de dezembro de $1906^{100}$ :

\begin{abstract}
V. Exa. sabe que os mesmos depois de completarem o curso nos grupos escholares das cidades do interior, principalmente onde não existem estabelecimentos de instrucção superior, procuram collocação no commercio ou na lavoura. Portanto seria conveniente que o estudo de arithmetica fosse mais desenvolvido e que ao programma se addiccionassem algumas noções de escripturação mercantil e de agricultura (Ordem 6935).
\end{abstract}

Se o relatório da professora Maria Marcolina permite concluir, como pondera Julia (2002), de que não é porque uma matéria não aparece nos programas de ensino que ela não é ensinada, o relatório de sua colega Georgina, assim como o de Eliza R. Macedo e aqueles dos diretores de grupos escolares ilustram exatamente o lado inverso dessa relação entre os programas e os sujeitos escolares, também mostrada pelo autor: "não é porque a finalidade de uma disciplina é explicitamente indicada nos textos normativos que ela existe no ensino real das salas" (2002, p.50). É precisamente por isso que Julia (2001) adverte que as normas e as práticas que formam a cultura escolar não podem ser investigadas sem se considerar o professor primário, agente encarregado de cumprir as primeiras. É preciso salientar, todavia, que - no caso da Escola-Modelo "Maria José" e dos grupos escolares acima mencionados possivelmente não eram os docentes, mas sim os próprios diretores aqueles que decidiam aprofundar o ensino de certas matérias.

Mas se professores e diretores desobedeciam à determinação legal de que o "ensino de todas as materias será ministrado nas respectivas classes, de inteiro accôrdo com o programma em vigor, sem preferencia de umas sobre as outras materias" (Artigo $7^{\circ}$. do Decreto n. 1216, de 27 de abril de 1904), o certo é que havia, de certa forma, uma hierarquia "oficial" dos saberes escolares que levava aqueles a contrariar tal norma. De fato, ao analisar os horários-

\footnotetext{
${ }^{100}$ Seu nome não foi identificado.
} 
modelo $^{101}$ publicados nos Anuários do Ensino em 1907-1908, em 1909-1910 e em 1922, Gallego (2003) conclui que a Leitura, a Aritmética, a Linguagem Escrita e a Caligrafia, ocupavam neles um lugar de destaque, pois deviam ser ministradas diariamente. Ademais, os mesmos profissionais que averiguavam, em suas visitas pelas escolas, que nem todos os professores ensinavam todas as matérias prescritas pelos programas de ensino, não deixavam de expressar a importância que atribuíam a algumas delas. À guisa de ilustração, Miguel Carneiro Junior - diretor do Grupo Escolar do Brás (seção masculina), em 1899 - fazia a seguinte avaliação: "O ensino no Grupo deixa a desejar si considerarmos todas as materias do programma. (...) Note-se, porém, que as materias mais essenciaes, leitura e calculo principalmente, ensina-se no Grupo mais ou menos bem" (21 de outubro de 1905 - Ordem 7037). O próprio inspetor escolar Antonio Rodrigues Alves Pereira também não escondia, em relatório de 1900, que o ensino da Linguagem era, em seu entender, um dos mais importantes. Apesar disso, era desenvolvido, em quase todas as escolas públicas primárias, de uma forma insatisfatória: "Em regra os professores para attender a exhibições em epochas de exames ou outras, põem de lado estas pequenas, porem importantes cousas, em beneficio das noções de sciencias naturaes, geometria e outras, as quaes o povo mais admira, por estarem fóra do commum" (Ordem 7026). Três outros inspetores concordavam com Pereira sobre a relevância da Linguagem. Um deles era João F. Pinto e Silva, que se referia a ela como "o eixo capital, que dá movimentação a toda a engrenagem do ensino" (Anuários do Ensino de 1910-1911, p.41). Outro era Benedito Maria Tolosa, que a considerava como "uma disciplina de real importancia, visto como se encontra em intimas relações com todas as demais materias dos programmas preliminares" (Anuários do Ensino de 1915, p.XXIX). Por último, nas palavras de Leopoldo Sant'anna, o ensino dela era a "base de todos os outros, e que, por isso mesmo, deve ser considerado, quanto à cultura intellectual, o alvo central da escola primaria" (Anuários do Ensino de 1915, p.XXXIX). Tanto quanto os inspetores escolares, os colaboradores dos periódicos educacionais também não se intimidavam em demonstrar sua predileção pela Linguagem escrita. Oscar Leme Brisolla, por exemplo, era explícito: “(...) tem sido sempre a minha preoccupação constante, o meu sonho eterno de acordado, a uniformisação da LINGUAGEM ESCRIPTA em nossas escolas, disciplina importantissima, que pesa, com uma responsabilidade grande sobre os hombros do educador consciente e digno

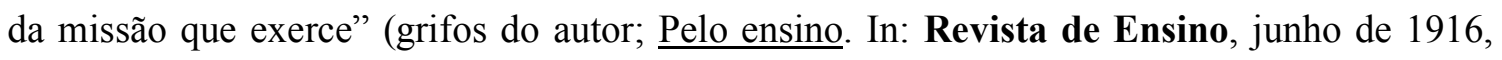

\footnotetext{
${ }^{101}$ Nas escolas-modelo, os professores deviam seguir horários-modelo, ao passo em que, nos grupos escolares, até meados de 1900, esses profissionais eram obrigados a obedecer aos horários produzidos pelos diretores. Já nas escolas isoladas, antes do início da publicação dos horários-modelo, eram os próprios docentes quem organizavam os horários (Gallego, 2003).
} 
p.23). Por sua vez, na opinião de Ataliba de Oliveira, entre "as materias consignadas no programma dos grupos escolares, a linguagem escripta occupa, incontestavelmente, um logar de destaque pela real importancia de que se reveste, attrahindo para si a maior attenção dos que se consagram ao difficil mistér de leccionar á infancia as primeiras letras” (grifos do autor; Linguagem escripta. In: Revista de Ensino, março de 1917, n. 04, ano XV, p.24).

Se eram fartas as referências encontradas nos relatórios e nas revistas pedagógicas sobre quais matérias recebiam - ou deviam receber - um tratamento especial, essas mesmas fontes, embora em menor intensidade, apontaram quais eram aquelas deixadas de lado. Não por coincidência, à exceção da Educação cívica, tratavam-se justamente das matérias que os professores afirmavam não lecionar, fosse pela falta de materiais ou de espaço apropriado, fosse pela insuficiente formação profissional, quais sejam, a Ginástica, os Exercícios militares, a Música, os Trabalhos Manuais e o Desenho. A respeito da primeira, o inspetor escolar Leopoldo Sant'anna observava que "sómente em alguns grupos escolares é dado o ensino com algum aproveitamento; nas escolas isoladas é, com raras e honrosas excepções, completamente descurado" (Anuários do Ensino de 1913, p.LXXXIX). Aristides de Castro confirmava que a Educação cívica era uma matéria "julgada árida e sem attractivos por muitos professores" (Anuários do Ensino de 1913, p.XLII). Quanto à Ginástica o inspetor escolar Miguel Carneiro Junior assim posicionava-se:

\footnotetext{
No período de exclusivismo intellectual que atravessamos, nenhum povo tem, talvez, mais necessidade de exercicio physico do que nós. Entretanto, a educação physica é quasi abandonada em nossas escolas.

Os programmas consignam - gymnastica e exercicios militares que, na maioria dos grupos e na quasi totalidade das escolas isoladas, não se pratica senão como elemento decorativo para festas.
}

Sobre os Exercícios militares, Augusto de Carvalho via como "necessario que todos se lembrem que se ministra o manejo da arma nas escolas, assim como se ensina historia, geographia, etc., e outras materias, que devem compôr um bom programma de estudos" (grifos do autor; A instrucção militar. In: Revista de Ensino, n. 04, ano VII, p.05). Já em relação à Música, Antonio Morato de Carvalho pontuava: "Merece especial attenção esta disciplina, cujo estudo, fazendo parte de nosso programma, tem sido, entretanto, tão descurado" (Anuários do Ensino de 1910-1911, p.128). No que tange aos Trabalhos Manuais, Benedicto Maria Tolosa mencionava que as "meninas ainda os praticam com certa regularidade. Os meninos pouco fazem, ou quasi nada: entre estes quasi desappareceu essa disciplina. Entretanto, bem merecia ser reanimado esse ensino" (Anuários do Ensino de 
1910-1911). Acerca dessa mesma matéria, Guilherme Kuhlmann sustentava que a "escola primaria não póde ser verdadeiramente educativa sem a pratica constante e methodica do trabalho manual. Não obstante a evidencia deste asserto, esta importante disciplina tem sido relegada para ultimo plano" (Anuários do Ensino de 1915, p.XXXV). Por fim, José Juliano Netto lamentava que ela estava

sendo ministrada ao bel praser de muitos professores, isto é, sem obediencia alguma a methodos (...).

(...) Pena é, portanto, que todos os dirigentes de estabelecimentos de ensino não cuidem com mais carinho dessa importante parte do programma, chegando mesmo alguns a abandonarem por completo tal ensino, contra determinações superiores, allegando quasi sempre a falta de meios ou a nenhuma utilidade (Trabalhos manuaes. In: Revista de Ensino, dez./1917-março/1918, ns. 03-04, ano XVII, p.53).

Afora a Educação cívica, a explicação encontrada para a falta do ensino das demais matérias antes citadas era o despreparo dos professores. Os Exercícios militares, por exemplo, não faziam parte da formação dada pela Escola Normal e pelos cursos complementares às alunas. Como a grande parte do corpo docente dos grupos escolares era composta por mulheres, as mesmas não podiam se tornar instrutoras de exercícios militares (Souza, 1997). Por outro lado, referindo-se ao Desenho, Theodoro Braga denunciava que se permitia que "individuos, investidos da qualidade de professores sem que tal possuam elles a mais leve noção daquillo para que são chamados a leccionar, a autoridade de pontificar sobre tal

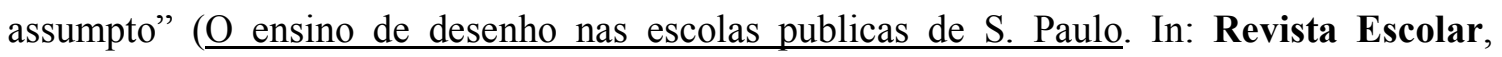

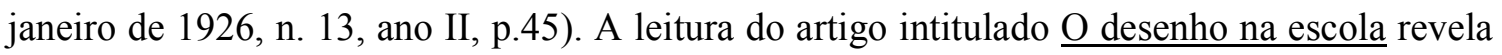
que seu autor - identificado apenas pelas iniciais A.R. - estava em consonância com a posição de Braga:

O Desenho é uma das disciplinas que nem sempre se pódem ensinar, com successo e proveito, nas escolas publicas e privadas. Porque? Porque nem todos os professores nasceram com a aptidão artistica necessaria para esse especial mester. Sem vocação artistica, sem jeito para o Desenho, não saberá o professor iniciar os seus alumnos nas bellezas da Arte. Eis porque, nos grupos escolares e na escolamodelo, sempre se devia confiar a um especialista contractado ou não, o ensino do Desenho: imitar-se-ia o que se faz com as aulas de Gymnastica e de Musica (In: Revista de Ensino, junho de 1907, n. 03, ano VI, p.26) ${ }^{102}$.

Devido àquilo que era visto como incompetência dos professores, a própria legislação escolar criou mecanismos para garantir que a Ginástica, os Exercícios militares, a Música, os Trabalhos Manuais e o Desenho fossem ensinados, desincumbindo-se, em certos momentos,

${ }^{102}$ Somente as escolas-modelo dispunham de professores especialmente contratados para o ensino da Música, dos Trabalhos Manuais, do Desenho e dos Exercícios militares (Souza, 1997, p.194). 
o docente dessa tarefa (Gallego, 2003). Nesse sentido, de acordo com o Artigo 62 do Decreto n. 518, de 11 de janeiro de 1898, o auxiliar do diretor de grupo escolar podia ministrar "o exercicio de musica, trabalhos manuaes, gymnastica e exercicios militares, quando para isso designado pelo director". A partir, porém, do Decreto n. 1239, de 30 de setembro de 1904, o ensino de tais matérias deveria voltar a ser "ministrado pelos próprios professores" (Artigo 32). Tal medida provocou fortes oposições por parte dos inspetores escolares, tais como Antonio Morato de Carvalho:

(...) Tendo o artigo 32 da Lei de 30 de Setembro de 1904 determinado que o ensino de musica, trabalhos manuaes, gymnastica e exercicio militar seja ministrado pelos proprios professores preliminares, foram então dispensados todos os professores especiaes contractados para os Grupos Escolares. Foi este um mal, que redundou em prejuizo do ensino de taes disciplinas e que deve ser logo remediado.

Si muitos de nossos professores não sabem musica, como poderão ensinal-a?

$\mathrm{O}$ remedio para este mal só pode vir da Escola Normal, quando os professores, dali sahindo, souberem que na vida pratica vão obedecer a um regulamento, de que nunca ouviram fallar; que esse regulamento estabelece um programma, que nunca viram, e que esse programma consigna certo numero de materias que deverão ensinar a seus alumnos, e das quaes forçosamente estarão já esquecidos, por não terem dellas feito, no ultimo anno do curso, uma recapitulação geral, nem estudado praticamente as normas que devem adoptar para a transmissão dos conhecimentos ás creanças (Anuários do Ensino de 1910-1911, p.128).

Além de Carvalho, outro inspetor escolar, João Pinto e Silva, também foi contrário àquela nova norma:

cumpre não esquecer a necessidade palpitante de serem as aulas de desenho, musica, gymnastica e trabalhos manuaes desempenhadas por profissionaes, especialmente contratados para tal fim, como se fazia antigamente.

São duas as principaes vantagens que decorre dessa medida: $1^{\circ}$. - melhor ensino, por isso que essas disciplinas constituem verdadeiras especialidades que raros professores publicos cultivam; $2^{\circ}$. - alivio á actividade dos professores, que assim a empregarão com mais energia e com mais proveito no ensino das outras disciplinas do programma (Anuários do Ensino de 1910-1911, p.47).

Mais tarde, o Decreto n. 2225, de 16 de abril de 1912, definiu que, além "das disciplinas que constituem o ensino de cada anno ou secção do curso, são os professores obrigados ao ensino de musica, cantos escolares e gymnastica" (Artigo 109). Essas disposições legais, no entanto, perduraram somente até o Decreto n. 4101, de 14 de dezembro de 1926, que regulamentou a Reforma da Instrução Pública de 1925. Desde então, foram nomeados seis inspetores especiais ${ }^{103}$, sendo que dois deles deveriam se ocupar do ensino de Trabalhos Manuais (um para as escolas masculinas e uma para as escolas femininas); uma das

${ }^{103}$ Conforme o Artigo 21 do Decreto n. 4101, os inspetores especiais "serão nomeados pelo Governo, mediante proposta do Director Geral da Instrucção Publica, dentre os professores de comprovada competencia para a especialidade de que se tratar". 
escolas maternais e creches; um do ensino de Música; um do ensino de Desenho e um do ensino de Exercícios ginásticos (Artigo 22).

A exigência legal feita aos professores para que enviassem periodicamente relatórios de ensino; a fiscalização dos diretores de escolas-modelo e de grupos escolares em relação aqueles; as visitas dos inspetores escolares; os textos publicados nos periódicos educacionais... Se esses foram alguns dos muitos mecanismos criados pelo Estado para garantir a execução perfeita dos programas de ensino, ou melhor, para construir uma nova identidade docente, condizente com a ampliação das finalidades da antiga escola primária (Lawn, 2000), o certo é que nada disso foi capaz de impedir a existência de diferenças entre as finalidades de objetivo e as finalidades reais, como Chervel (1990) refere-se ao hiato entre as matérias constantes nos programas de ensino oficiais e aquelas ensinadas no dia-a-dia das escolas. Por um lado, devia-se isso à prática de se ensinar mais do que pediam os programas ou, ao contrário - e muito mais comum - de se deixar certas partes desse de lado. Por outro lado, se, de acordo com os relatórios escritos pelos diretores de grupos escolares, a falta de condições materiais afetou até mesmo esse tipo de escola primária tomada como símbolo da modernização educacional, não é difícil imaginar as dificuldades sofridas cotidianamente pelos professores das escolas isoladas, relegadas ao esquecimento como conseqüência do mesmo processo que privilegiou os primeiros. No caso das escolas isoladas, portanto, não era de se estranhar o desinteresse em dotá-las de uma adequada infra-estrutura. $\mathrm{O}$ fato, porém, de que problemas da mesma ordem também atingiam os grupos escolares, evidencia que os planos de renovação do ensino formulados pelas elites foram desmoronando diante de um sistema primário no qual não havia condições reais para implementá-los, fossem elas verbas suficientes para o provimento material das escolas, fossem cursos que preparassem adequadamente os professores. 


\section{CONSIDERAÇÕES FINAIS}

A presente dissertação de mestrado buscou colaborar com os estudos na área da História da Educação Brasileira. Isso porque, ela integrou, em uma mesma questão, dois temas ainda insuficientemente investigados: a diversidade de escolas públicas primárias paulistas e os saberes escolares selecionados para o nível primário. Para isso, e tendo como pressuposto que uma análise histórica sobre a educação não pode ser iniciada sem se conhecer o contexto histórico mais amplo no qual ela se insere, o primeiro capítulo teve como um dos objetivos apresentar as transformações sociais e econômicas que atingiram a então Província de São Paulo especialmente a partir de 1870. Tendo se tornado o centro econômico do país em virtude da expansão da cultura cafeeira, o futuro Estado de São Paulo dependia, pois, fundamentalmente, da agricultura para sustentar-se. Não à toa, foi realizado um grande empenho para se importar a mão-de-obra que seria responsável pelas lavouras. Por outro lado, com a própria renda obtida com o sucesso do café, as elites paulistas deram início ao processo de modernização das cidades, notadamente da Capital. Ansiosas por imprimir a elas uma fisionomia européia, elas não pouparam esforços quando se tratava do processo de renovação de todos os setores da vida social. Enquanto instituição que cada vez mais ganhava relevância na sociedade, a escola primária não podia deixar de ser objeto de atenção das elites. Assim, a criação das escolas-modelo e, logo em seguida, dos grupos escolares, representou mais um dos muitos melhoramentos urbanos. Não tardou, porém, para que o projeto de inovação educacional produzisse seu efeito mais perverso: o descaso com as escolas isoladas. Incluídas no rol daquilo que as elites classificavam como obstáculos do progresso - no qual já figuravam, por exemplo, as tradições culturais africanas banidas do centro da cidade de São Paulo - esse tipo de escola primária poucos benefícios recebia, tendo sido um deles a implementação das escolas-modelo isoladas. Ainda no tocante ao grau de importância dada pelo Estado a cada uma das modalidades de escolas primárias, a história das escolas reunidas expressa com clareza como o interesse daquele era o fator que definia o destino da escola. Fortemente criticadas mesmo antes de serem oficializadas, seus pontos positivos só passaram a ser propagandeados quando os índices de analfabetismo soaram como alarmantes aos olhos das autoridades educacionais. 
Como o primeiro capítulo permitiu aquilatar o peso desigual atribuído aos diferentes tipos de escolas primárias pelo poder público, o processo de diferenciação dos programas de ensino, quando inaugurado no começo da década de 1900, pôde ser mais facilmente compreendido. A avaliação, tanto por parte dos inspetores escolares quanto por alguns professores, de que os programas de ensino das escolas preliminares eram impraticáveis nas escolas isoladas, foi o que engendrou aquele. Entretanto, no momento de se escolher o que essas deviam ensinar, os primeiros profissionais da educação não hesitaram: bastavam os saberes elementares para crianças que, ao seu ver, pouco ou nada aspiravam seguir uma carreira que não fosse ligada ao campo. Os programas de ensino oficiais criados para as escolas isoladas, como explicado, embora não se limitassem ao ler, ao escrever e ao contar, iam pouco além disso, ao oferecer apenas, como complemento principal daquelas matérias básicas, rudimentos científicos cuja finalidade era despertar o gosto pela vida rural. Essa visão geral das matérias e dos conteúdos incluídos nos programas de ensino das escolas isoladas foi feita também no que se refere às escolas-modelo e aos grupos escolares. Dessa vez, foi possível constatar que, ao longo de todo o período analisado, a prioridade dessas duas escolas localizadas nos centros urbanos residia na nacionalização e na moralização das crianças que as freqüentavam. A primeira era imprescindível ao se considerar o número expressivo de filhos de pais estrangeiros matriculados nas escolas graduadas. Quanto à segunda meta, se essa já era crucial devido às condições de vida nas precárias habitações populares, ela tornou-se ainda mais no momento em que as greves operárias começaram a eclodir na Capital. O final dos anos de 1910 também foi o marco das mudanças na questão do que ensinar nas escolas primárias. Além da Reforma Sampaio Dória ter assinalado a equiparação dos programas de ensino das escolas isoladas, das escolas reunidas e dos grupos escolares, dois anos antes dela, os programas de ensino elaborados para os três subtipos das primeiras já sinalizavam a tendência em se modificar os objetivos por elas perseguidos até a ocasião. Antes desenvolvidos de forma secundária, o amor à Pátria e a formação do caráter passaram, com a difusão das idéias nacionalistas, a serem os pilares do ensino dirigido aos moradores do campo. O fato de que - assim como as escolas-modelo e os grupos escolares, as escolas isoladas, a partir de então, também deviam privilegiar a educação moral e cívica - não significou, contudo, o fim da discriminação social que sempre embasou a diferenciação dos programas de ensino. Isso porque, apesar dos discursos dos inspetores escolares veicularem a necessidade de se prestar atenção especial às populações rurais, o destino social para elas formulado não sofria qualquer alteração: era preciso nacionalizá-las e moralizá-las sim, mas para que elas permanecessem no campo, como já ocorria. 
A última parte da dissertação, por sua vez, deslocou a ênfase, colocada pelo capítulo segundo na história formal dos programas de ensino, para as inúmeras possibilidades encontradas pelos diversos sujeitos escolares no enfrentamento da rigidez das normas. Com efeito, longe de se manterem passivos ao que determinava a legislação escolar, colaboradores dos periódicos educacionais, professores, diretores de escolas-modelo e de grupos escolares, além dos inspetores escolares, de uma forma ou de outra, contribuíam para relativizar o poder absoluto dos imperativos legais. É nesse sentido que os primeiros, por exemplo, apresentaram seus critérios do que seria o programa de ensino ideal. Assim, esse deveria ser elaborado pelos próprios professores e não poderiam ser extensos, isto é, privilegiar o ensino de certas matérias ou então ser compostos por saberes escolares que não obedecessem ao desenvolvimento natural das faculdades infantis. Por sua vez, as lutas em torno do que deviam ensinar as escolas primárias e, em especial, as escolas isoladas, reiteraram e, de certo modo, legitimaram a necessidade de diferenciar os programas do ensino primário. Por fim, as lacunas entre a prescrição e a prática mostraram os limites dos dispositivos de controle e de supervisão do trabalho docente e também do processo de inovação educacional.

Como sugestões para futuras pesquisas, provocadas por questões deixadas abertas pelo presente trabalho, seriam oportunas aquelas dedicadas a aprofundar a história de determinadas matérias constantes dos programas de ensino, em direção oposta à interpretação mais geral aqui empreendida das finalidades das matérias e dos conteúdos. Também seriam de grande contribuição estudos que analisassem, conjuntamente, os programas do ensino primário e aqueles dos cursos de formação de professores, uma vez que, ao que tudo indica, mudanças nos primeiros não eram acompanhadas de alterações nos segundos. 


\section{FONTES E REFERÊNCIAS BIBLIOGRÁFICAS}

\section{Fontes}

Coleção de Leis e Decretos do Estado de São Paulo. São Paulo: Imprensa Oficial do Estado, 1889-1972.

Anuários do Ensino do Estado de São Paulo. São Paulo: Diretoria Geral da Instrução Pública/Secretaria da Educação e Saúde Pública, 1907-1937.

Educação. São Paulo: Diretoria Geral da Instrução Pública/Sociedade de Educação de São Paulo, 1927-1961.

Revista de Ensino. São Paulo: Associação Beneficente do Professorado Público de São Paulo/ Diretoria Geral da Instrução Pública, 1902-1919.

Revista Escolar. São Paulo: Diretoria Geral da Instrução Pública, 1925-1927.

Relatórios de diretores de grupos escolares e de escolas-modelo (1897-1907) manuscritos/Arquivo Público do Estado de São Paulo.

Relatórios de inspetores escolares (1896-1906) - manuscritos/Arquivo Público do Estado de São Paulo.

Relatórios de professores (1890-1897) - manuscritos/Arquivo Público do Estado de São Paulo.

Referências Bibliográficas

AMERICANO, Jorge. São Paulo naquele tempo (1895-1915). 2a . edição. São Paulo: Carrenho Editorial; Narrativa Um; Carbono 14, 2004.

ANTUNHA, Heládio César Gonçalves. A instrução pública no Estado de São Paulo - a Reforma de 1920. São Paulo: Faculdade de Educação da Universidade de São Paulo, 1976 (Série Estudos e Documentos, vol.12).

BARROS, Roque Spencer Maciel de. A ilustração brasileira e a idéia de Universidade. São Paulo: Faculdade de Filosofia, Ciências e Letras da Universidade de São Paulo, 1959.

BITTENCOURT, Circe Maria Fernandes. Produção didática e programas de ensino das escolas paulistas nas primeiras décadas do século $X X$. Revista da Faculdade de Educação, São Paulo, 15(2), p.167-187, jul.-dez./1989. 
Pátria, civilização e trabalho - o ensino de História nas escolas paulistas (19171939). São Paulo: Loyola, 1990.

Disciplinas escolares: história e pesquisa. In: OLIVEIRA, Marcus Aurelio Taborda; RANZI, Serlei Maria Fisher (orgs.). História das disciplinas escolares no Brasil: contribuições para o debate. Bragança Paulista, SP: EDUSF, 2003, p.09-38.

BOURDIEU, Pierre. Os usos sociais da ciência: por uma sociologia clínica do campo científico. Tradução de Denice Barbara Catani. São Paulo: Editora UNESP, 2004.

CAMARGO, José Francisco de. Crescimento da população no Estado de São Paulo e seus aspectos econômicos (ensaio sobre as relações entre a Demografia e a Economia). São Paulo: Faculdade de Filosofia, Ciências e Letras da Universidade de São Paulo, 1952.

CÂNDIDO, Renata Marcílio. Culturas da escola: as festas nas escolas públicas paulistas (1890-1930). Dissertação (Mestrado) - Faculdade de Educação, Universidade de São Paulo, São Paulo, 2007.

CARVALHO, Marta Maria Chagas de. O novo, o velho, o perigoso: relendo 'A cultura brasileira'. Cadernos de Pesquisa, São Paulo (71): 29-35, novembro/1989.

A escola e a República. São Paulo: Brasiliense, 1989.

Escola, memória, historiografia: a produção do vazio. São Paulo em perspectiva, 7(1): 10-15, jan.-março/1993.

- Molde nacional e fôrma cívica: higiene, moral e trabalho no projeto da Associação Brasileira de Educação (1924-1931). Bragança Paulista, SP: EDUSF, 1998.

Reformas da Instrução Pública. In: LOPES, Eliane Marta Teixeira; FARIA FILHO, Luciano Mendes de; VEIGA, Cynthia Greive (orgs.). 500 anos de educação no Brasil. Belo Horizonte: Autêntica, 2000, p.225-251.

. A República, a escola e os perigos do alfabeto. In: PRADO, Maria Lígia Coelho; VIDAL, Diana Gonçalves (orgs.). À margem dos 500 anos: reflexões irreverentes. São Paulo: EDUSP, 2002, p.203-218.

CASPARD, Pierre; CASPARD, Pénélope. Imprensa pedagógica e formação contínua de professores primários (1815-1939). In: CATANI, Denice Barbara; BASTOS, Maria Helena Camara (orgs.). Educação em Revista: a imprensa periódica e a História da Educação. São Paulo: Escrituras, 1997, p.33-46.

CATANI, Denice Barbara. Ensaios sobre a produção e circulação dos saberes pedagógicos. Tese (Livre-docência) - Faculdade de Educação, Universidade de São Paulo, São Paulo, 1994.

Informação, disciplina e celebração: os Anuários do Ensino do Estado de São Paulo. Revista da Faculdade de Educação da USP, São Paulo, v.21, p.09-30, jul.-dez./1995. 
- A imprensa periódica educacional: as revistas de ensino e o estudo do campo educacional. Educação e Filosofia, v.10, n.20, p.115-130, jul.-dez./1996.

- Leituras para professores: a imprensa pedagógica educacional e a orientação do trabalho pedagógico no Brasil republicano. In: FERNANDES, Rogério; ADÃO, Áurea (orgs.). Leitura e escrita em Portugal e no Brasil: 1500-1970. Actas do $1^{\circ}$ Congresso Luso-Brasileiro em História da Educação. Vol.3. Porto: Sociedade Portuguesa de Ciências da Educação, 1998a, p.279-288.

Educadores à meia luz: um estudo sobre a Revista de Ensino da Associação Beneficente do Professorado Público de São Paulo (1902-1918). Bragança Paulista, SP: EDUSF, 2003.

; LIMA, Ana Laura Godinho. Vigilância e controle: os Anuários do Ensino do Estado de São Paulo e a história do trabalho docente no Brasil (1907-1937). In: CATANI, Denice Barbara; BASTOS, Maria Helena Camara (orgs.). Educação em Revista: a imprensa periódica e a História da Educação. São Paulo: Escrituras, 1997, p.155-172.

CERTEAU, Michel. A invenção do cotidiano: artes de fazer. Petrópolis, RJ: Vozes, 2005.

CHARTIER, Anne-Marie; HÉBRARD, Jean. Discursos sobre a leitura: 1880-1980. Tradução de Osvaldo Biato e Sérgio Bath. São Paulo: Editora Ática, 1995.

CHARTIER, Roger. A história cultural: entre práticas e representações. Lisboa: Difel, 1990.

O mundo como representação. Estudos Avançados, São Paulo, v.5, n.11, p.173-191, jan.-abr./1991.

CHERVEL, André. História das disciplinas escolares: reflexões sobre um campo de pesquisa. Teoria \& Educação, Porto Alegre, n.2, p.177-229, 1990.

CORREIA, António Carlos. A alquimia curricular: um campo de pesquisa histórico e sociológico. Lisboa: Educa, 2000, p.05-39 (Cadernos Prestige n.01).

; GALlEGO, Rita de Cassia. Escolas públicas primárias em Portugal e em São Paulo: olhares sobre a organização do tempo escolar (1880-1920). Lisboa: Educa, 2004, p.07-47 (Cadernos Prestige n.21).

; SILVA, Vera Lúcia Gaspar da. A lei da escola: sentidos da construção da escolaridade popular através de textos legislativos em Portugal e Santa Catarina - Brasil (1880-1920). Revista Brasileira de História da Educação, Campinas, n.8, p.43-83, julho-dez./2004.

COSTA, Ana Maria Catelli Infantosi da. A escola na República Velha: expansão do ensino primário em São Paulo. São Paulo: EDEC, 1983.

CURY, Carlos Roberto Jamil. Ensino religioso na escola pública: o retorno de uma polêmica recorrente. Revista Brasileira de Educação, Rio de Janeiro, n.27, p.183-191, set.dez./2004. 
DEMARTINI, Zeila de Brito Fabri. Observações sociológicas sobre um tema controverso população rural e educação em São Paulo. Tese (Doutorado) - Faculdade de Filosofia, Letras e Ciências Humanas, Universidade de São Paulo, São Paulo, 1980.

; TENCA, Sueli Cotrim; TENCA, Álvaro. Os alunos e o ensino na República Velha através das memórias de velhos professores. Cadernos de Pesquisa, São Paulo (52): 6171 , fev./1985.

. Desigualdade, trabalho e educação: a população rural em questão. Cadernos de Pesquisa, São Paulo (64): 24-37, fev./1988.

. Cidadãos analphabetos: propostas e realidade do ensino rural em São Paulo na $1^{a}$. República. Cadernos de Pesquisa, São Paulo (71): 05-19, nov./1989a.

. O coronelismo e a educação na $1^{a}$. República. Educação \& Sociedade, p.44-74, dez./1989b.

Dora Lice. O calvário de uma professora. São Paulo: Estabelecimento Gráfico Irmãos Ferraz, 1927.

DUARTE, Geni Rosa. Rumo ao campo: a civilização pela escola - São Paulo, 1910/ 1920/1930. Dissertação (mestrado) - Faculdade de Educação, Pontifícia Universidade Católica de São Paulo, São Paulo, 1995.

ESTEVES, Isabel de Lourdes. As prescrições para o ensino da caligrafia e da escrita na escola pública primária paulista (1909-1947). Dissertação (Mestrado) - Faculdade de Educação, Universidade de São Paulo, São Paulo, 2002.

FARIA FILHO, Luciano Mendes de. Dos pardieiros aos palácios: forma e culturas escolares em Belo Horizonte (1906-1918). Tese (Doutorado) - Faculdade de Educação, Universidade de São Paulo, São Paulo, 1996.

- A legislação escolar como fonte para a História da Educação: uma tentativa de interpretação. In:_ ; et al (orgs.). Educação, modernidade e civilização: fontes e perspectivas de análise para a história da educação brasileira. Belo Horizonte: Autêntica, 1998, p.91-125.

. Instrução elementar no século XIX. In: LOPES, Eliane Marta Teixeira; FARIA FILHO, Luciano Mendes de; VEIGA, Cynthia Greive (orgs.). 500 anos de educação no Brasil. Belo Horizonte: Autêntica, 2000, p.135-150.

- Escolarização, culturas e práticas escolares no Brasil: elementos teóricometodológicos de um programa de pesquisa. In: LOPES, Alice Casimiro; MACEDO, Elisabeth (orgs.). Disciplinas e integração curricular: história e políticas. Rio de Janeiro: DP\&A, 2002, p.13-35.

; GONÇALVES, Irlen Antônio; VIDAL, Diana Gonçalves; PAULILO, André Luiz. A cultura escolar como categoria de análise e como campo de investigação na história da educação brasileira. Educação e Pesquisa, São Paulo, v.30, n.1, p.139-159, jan.-abril/ 2004. 
; GONÇALVES, Irlen Antônio. História das culturas e das práticas escolares: perspectivas e desafios teórico-metodológicos. In: SOUZA, Rosa Fátima de; VALDEMARIN, Vera Teresa (orgs.). A cultura escolar em debate - questões conceituais, metodológicas e desafios para a pesquisa. Campinas, SP: Autores Associados, 2005, p.31-57.

; SOUZA, Rosa Fátima de. A contribuição dos estudos sobre grupos escolares para a renovação da história do ensino primário no Brasil. In: VIDAL, Diana Gonçalves (org.). Grupos escolares: cultura escolar primária e a escolarização da infância no Brasil (1893-1971). Campinas, SP: Mercado de Letras, 2006, p.21-56.

FAUSTO, Boris. História do Brasil. São Paulo: Edusp, 2007.

FORQUIN, Jean-Claude. Saberes escolares, imperativos didáticos e dinâmicas sociais. Teoria \& Educação, Porto Alegre, n.5, p.28-49, 1992.

FRAGO, Antonio Viñao. Historia de la educación e historia cultural. Revista Brasileira de Educação, n.0, p.63-82, set.-dez./1995.

História das disciplinas escolares. Tradução de Marina Fernandes Braga. Revista Brasileira de História da Educação, Campinas, n.18, p.174-215, set.-dez./2008.

GALLEGO, Rita de Cassia. Uso(s) do tempo: a organização das atividades de alunos e professores nas escolas primárias paulistas (1890-1929). Dissertação (Mestrado) Faculdade de Educação, Universidade de São Paulo, São Paulo, 2003.

. Tempo, temporalidades e ritmos nas escolas primárias públicas em São Paulo: heranças e negociações (1846-1890). Tese (Doutorado) - Faculdade de Educação, Universidade de São Paulo, São Paulo, 2008.

GLEZER, Raquel. Chão de terra e outros ensaios sobre São Paulo. São Paulo: Alameda, 2007.

GONDRA, José Gonçalves. Medicina, higiene e educação escolar. In: LOPES, Eliane Marta Teixeira; FARIA FILHO, Luciano Mendes de; VEIGA, Cynthia Greive (orgs.). 500 anos de educação no Brasil. Belo Horizonte: Autêntica, 2000, p.519-550.

GOODSON, Ivor F. Currículo: teoria e história. Petrópolis, RJ: Vozes, 1995.

A construção social do currículo. Lisboa: Educa, 1997.

HALL, Michael. Imigrantes na Cidade de São Paulo. In: PORTA, Paula (org.). História da cidade de São Paulo: a cidade na primeira metade do século XX. Vol.3. São Paulo: Paz e Terra, 2004, p.121-151.

O movimento operário na Cidade de São Paulo: 1890-1954. In: PORTA, Paula (org.). História da cidade de São Paulo: a cidade na primeira metade do século XX. Vol.3. São Paulo: Paz e Terra, 2004, p.259-289.

HAMILTON, David. Sobre as origens dos termos classe e curriculum. Teoria \& Educação, 
Porto Alegre, n.6, p.33-52, 1992.

HÉBRARD, Jean. A escolarização dos saberes elementares na época moderna. Teoria \& Educação, Porto Alegre, n.2, p.65-109, 1990.

HILSDORF, Maria Lucia Spedo. Mestra Benedita ensina primeiras letras em São Paulo (1828-1858). In: Atas do 1․ Seminário Docência, Memória e Gênero (GEDOMGEFEUSP). São Paulo: FEUSP; Plêiade, 1997, p.95-104.

HOBSBAWM, Eric. A era do capital: 1848-1875. Tradução de Luciano Costa Neto. Rio de Janeiro: Paz e Terra, 1982.

JARDIM, Vera Lúcia Gomes. "Os sons da República” - o ensino da Música nas escolas públicas de São Paulo na Primeira República (1889-1930). Dissertação (Mestrado) Pontifícia Universidade Católica de São Paulo, São Paulo, 2003.

Da arte à educação: a música nas escolas públicas (1838-1971). Tese (Doutorado) Pontifícia Universidade Católica de São Paulo, São Paulo, 2008.

JULIA, Dominique. A cultura escolar como objeto histórico. Revista Brasileira de História da Educação, Campinas, n.1, p.09-44, jan.-jun./2001.

Disciplinas escolares: objetivos, ensino e apropriação. In: LOPES, Alice Casimiro; MACEDO, Elisabeth (orgs.). Disciplinas e integração curricular: história e políticas. Rio de Janeiro: DP\&A, 2002, p.37-71.

KOWARICK, Lúcio. Trabalho e vadiagem: a origem do trabalho livre no Brasil. Rio de Janeiro: Paz e Terra, 1994.

LAWN, Martin. Os professores e a fabricação de identidades. In: NÓVOA, António; SCHRIEWER, Jürgen. A difusão mundial da escola: alunos, professores, currículo, pedagogia. Lisboa: Educa, 2000, p.69-84.

LOURENÇO FILHO, Manoel B. A questão dos programmas. Escola Nova, n.2, p.81-85, nov.-dez./1930.

LOVE, Joseph. A Locomotiva: São Paulo na Federação Brasileira (1889-1937). Tradução de Vera Alice Cardoso da Silva. Rio de Janeiro: Paz e Terra, 1982.

MACHADO, Antônio de Alcântara. Brás, Bexiga e Barra Funda. São Paulo: Klick Editora, 1997.

MARCÍlIO, Maria Luiza. História da escola em São Paulo e no Brasil. São Paulo: Imprensa Oficial do Estado de São Paulo; Instituto Fernand Braudel, 2005.

MARTINS, José de Souza. O migrante brasileiro na São Paulo estrangeira. In: PORTA, Paula (org.). História da cidade de São Paulo: a cidade na primeira metade do século XX. Vol.3. São Paulo: Paz e Terra, 2004b, p.153-213. 
MATE, Cecília Hanna. Tempos modernos na escola: os anos 30 e a racionalização da educação brasileira. Bauru, SP: EDUSC; Brasília, DF: INEP, 2002.

MEYER, John. Globalização e currículo: problemas para a teoria em sociologia da educação. In: NÓVOA, António; SCHRIEWER, Jürgen (orgs.). A difusão mundial da escola. Lisboa: Educa, 2000, p.15-32.

MOACYR, Primitivo. A instrução e as Províncias (subsídios para a História da Educação no Brasil): 1835-1889. São Paulo: Companhia Editora Nacional, 1939.

MORAES, Dislane Zerbinatti. Literatura, memória e ação política: uma análise de romances escritos por professores. Dissertação (Mestrado) - Faculdade de Educação, Universidade de São Paulo, São Paulo, 1996.

MOREIRA, Antonio Flavio Barbosa. Currículos e programas no Brasil. Campinas, SP: Papirus, 1990.

MORILA, Ailton Pereira. No compasso do progresso - a música na escola nas primeiras décadas republicanas. Revista Brasileira de História da Educação, Campinas, n.12, p.75-119, jul.-dez./2006.

MORSE, Richard. Formação histórica de São Paulo (de comunidade à metrópole). São Paulo: Difusão Européia do Livro, 1970.

NAGLE, Jorge. Educação e sociedade na Primeira República. São Paulo: EPU; Editora da Universidade de São Paulo, 1974.

NÓVOA, António. Para o estudo sócio-histórico da gênese e desenvolvimento da profissão docente. Teoria \& Educação, Porto Alegre, n.4, p.109-139, 1991.

. A imprensa de educação e ensino: concepção e organização do repertório português. In: CATANI, Denice Barbara; BASTOS, Maria Helena Camara (orgs.). Educação em Revista: a imprensa periódica e a História da Educação. São Paulo: Escrituras, 1997, p.11-31.

OLIVEIRA, Marcus Aurélio Taborda de; MEURER, Sidmar dos Santos. Tensões entre o prescrito e o realizado na escolarização paranaense na década inicial do século XX: experiências de professores primários a partir da análise dos relatórios da instrução pública. In: OLIVEIRA, Marcus Aurélio Taborda de (org.). Cinco estudos em História e Historiografia da Educação. Belo Horizonte: Autêntica, 2007, p.69-88.

PATTO, Maria Helena Souza. A produção do fracasso escolar: histórias de submissão e rebeldia. São Paulo: Casa do Psicólogo, 1999.

. Estado, ciência e política na Primeira República: a desqualificação dos pobres. Estudos Avançados. 13(35), 1999, p.167-198.

PAZIANI, Rodrigo Ribeiro. Outras leituras da cidade: experiências urbanas da população de Ribeirão Preto durante a Primeira República. Tempo, Niterói, v.10, n.19, p.175-200, julho-dez./2005. 
PETITAT, André. Produção da escola/produção da sociedade: análise sócio-histórica de alguns momentos decisivos da evolução escolar no Ocidente. Tradução de Eunice Gruman. Porto Alegre: Artes Médicas, 1994.

PINHEIRO, Antonio Carlos Ferreira. Da era das cadeiras isoladas à era dos grupos escolares na Paraíba. Campinas, SP: Autores Associados; São Paulo: Universidade São Francisco, 2002.

POPKEWITZ, Thomas S. História do currículo, regulação social e poder. In: SILVA, Tomaz Tadeu da (org.). O sujeito da educação: estudos foucaultianos. Petrópolis, RJ: Vozes, 1995, p.173-210.

PRADO JR., Caio. Evolução política do Brasil e outros estudos. São Paulo: Editora Brasiliense, 1971.

RAGO, Luzia Margareth. Do cabaré ao lar: a utopia da cidade disciplinar (Brasil: 18901930). Rio de Janeiro: Paz e Terra, 1997.

REIS FILHO, Casemiro dos. A educação e a ilusão liberal: origens do ensino público paulista. Campinas, SP: Autores Associados, 1995.

Índice básico de legislação do ensino paulista (1890-1945). Campinas, SP: Gráfica/FE, Gráfica Central/UNICAMP, 1998.

RESENDE, Fernanda Mendes; FARIA FILHO, Luciano Mendes de. História da política educacional em Minas Gerais no século XIX: os relatórios dos presidentes da província. Revista Brasileira de História da Educação, Campinas, n.2, p.79-115, julho-dez./2001.

RIBEIRO, Ricardo. Professoras de outrora - escola primária paulista (1925-1950). Tese (Doutorado). Faculdade de Educação, Universidade de São Paulo, São Paulo, 1996.

SACRISTAN, Jose Gimeno. El curriculum: una reflexion sobre la pratica. Madrid: Ediciones Morata, 1991.

SAES, Flávio. São Paulo republicana: vida econômica. In: PORTA, Paula (org.). História da cidade de São Paulo: a cidade na primeira metade do século XX. Vol.3. São Paulo: Paz e Terra, 2004, p.215-257.

SANTOS, Carlos José Ferreira dos. Nem tudo era italiano: São Paulo e pobreza (18901915). São Paulo: Annablume; FAPESP, 2003.

SEGAWA, Hugo. São Paulo - veios e fluxos (1872-1954). In: PORTA, Paula (org.). História da cidade de São Paulo: a cidade na primeira metade do século XX. Vol.3. São Paulo: Paz e Terra, 2004, p.341-385.

SEVCENKO, Nicolau. A Revolta da Vacina - mentes insanas em corpos rebeldes. São Paulo: Brasiliense, 1984.

O prelúdio republicano, astúcias da ordem e ilusões do progresso. In: (org.). História da vida privada no Brasil 3 - República: da Belle Époque à Era do Rádio. 
São Paulo: Companhia das Letras, 2006, p.07-48.

SILVA, Denise Guilherme da. "Ilhas de saber": prescrições e práticas das escolas isoladas do estado de São Paulo (1933-1943). Dissertação (mestrado) - Faculdade de Educação, Pontifícia Universidade Católica de São Paulo, São Paulo, 2004.

SILVA, Tomaz Tadeu da. Identidades terminais: as transformações na política da pedagogia e na pedagogia da política. Petrópolis, RJ: Vozes, 1996.

Documentos de identidade: uma introdução às teorias do currículo. Belo Horizonte: Autêntica, 2007.

O currículo como fetiche: a poética e a política do texto curricular. Belo Horizonte: Autêntica, 1999.

SOUZA, Maria Cecilia Cortez Christiano de. Decorar, lembrar e repetir: o significado de práticas escolares na escola brasileira do final do século XIX. In: SOUZA, Cynthia Pereira de (org.). História da Educação: processos, práticas e saberes. São Paulo: Escrituras, 1998, p.83-93.

SOUZA, Rosa Fátima de. Templos de civilização: um estudo sobre a implantação dos grupos escolares no Estado de São Paulo (1890-1910). Tese (Doutorado) - Faculdade de Educação, Universidade de São Paulo, São Paulo, 1997.

O direito à educação: lutas populares pela escola em Campinas. Campinas, SP: Editora da UNICAMP, 1998.

- Tempos de infância, tempos de escola: a ordenação do tempo escolar no ensino público paulista (1892-1933). Educação e Pesquisa, São Paulo, v.25, n.2, p.127-143, jul.dez./1999.

. Um itinerário de pesquisa sobre a cultura escolar. In: CUNHA, Marcus Vinicius da (org.). Ideário e imagens da educação escolar. Campinas, SP: Autores Associados, 2000a, p.03-27.

Inovação educacional no século XIX: a construção do currículo da escola primária no Brasil. Cadernos Cedes, Campinas, ano XIX, n.51, p.09-28, nov./2000b.

- A militarização da infância: expressões do nacionalismo na cultura brasileira. Cadernos Cedes, Campinas, ano XIX, n.52, p.104-121, nov./2000c.

Lições da escola primária. In: SAVIANI, Dermeval; et al (orgs.). O legado educacional do século XX no Brasil. Campinas, SP: Autores Associados, 2004, p.111161.

. Cultura escolar e currículo: aproximações e inflexões nas pesquisas históricas sobre conhecimentos e práticas escolares. In: XAVIER, Libânia Nacif (org.). Escola, culturas e saberes. Rio de Janeiro: FGV, 2005a, p.74-91.

. Tecnologias de ordenação escolar no século XIX: currículo e método intuitivo nas 
escolas primárias norte-americanas (1860-1880). Revista Brasileira de História da Educação, Campinas, n.9, p.09-42, jan.-jun./2005b.

História da organização do trabalho escolar e do currículo no século XX (ensino primário e secundário no Brasil). São Paulo: Cortez Editora, 2008.

SPENCER, Herbert. Educação intelectual, moral e fisica. São Paulo: Cultura Moderna, s/d.

SCHWARCZ, Lilia Moritz. O espetáculo das raças: cientistas, instituições e questão racial no Brasil - 1870-1930. São Paulo: Companhia das Letras, 1993.

TANURI, Leonor Maria. O ensino normal no Estado de São Paulo (1890-1930). São Paulo: FEUSP, 1979 (Série Estudos e Documentos, vol.16).

TAVARES, Fausto Antonio Ramalho. Na marcha do ensino. A organização burocrática do ensino estadual no São Paulo republicano: 1892-1910. Tese (Doutorado) Faculdade de Educação, Universidade de São Paulo, São Paulo, 2004.

TERIGI, Flávia. Notas para uma genealogia do curriculum escolar. Educação \& Realidade, Porto Alegre, 21(1), p.159-186, jan.-jun./1996.

VAGO, Tarcísio Mauro. Cultura escolar, cultivo de corpos: educação physica e gymnastica como práticas constitutivas dos corpos de crianças no ensino público primário de Belo Horizonte (1906-1920). Bragança Paulista, SP: EDUSF, 2002.

Fontes para a História da Educação: notas de um percurso de pesquisa. In: MORAIS, Christianni Cardoso; PORTES, Écio Antônio; ARRUDA, Maria Aparecida (orgs.). História da Educação: ensino e pesquisa. Belo Horizonte: Autêntica, 2006, p.59-70.

VALDEMARIN, Vera Teresa. Lições de coisas: concepção cientifica e projeto modernizador para a sociedade. Cadernos Cedes, Campinas, ano XIX, n.52, p.74-87, nov./2000.

VARELA, Julia; ALVAREZ-URIA, Fernando. A maquinaria escolar. Teoria \& Educação, Porto Alegre, n.6, p.68-96, 1992.

VECHIA, Ariclê. O plano de estudos das escolas públicas elementares na Província do Paraná: ler e escrever, para Deus e o Estado. Revista Brasileira de História da Educação, Campinas, n.7, p.135-160, jan.-jun./2004.

VEIGA, Cynthia Greive. Educação estética para o povo. In: LOPES, Eliane Marta Teixeira; FARIA FILHO, Luciano Mendes de; VEIGA, Cynthia Greive (orgs.). 500 anos de educação no Brasil. Belo Horizonte: Autêntica, 2000, p.399-422.

VIDAL, Diana Gonçalves. Culturas escolares: estudo sobre práticas de leitura e escrita na escola pública primária (Brasil e França, final do século XIX). Campinas, SP: Autores Associados, 2005.

Cultura e práticas escolares: uma reflexão sobre documentos e arquivos escolares. In: SOUZA, Rosa Fátima de; VALDEMARIN, Vera Teresa (orgs.). A cultura escolar em debate - questões conceituais, metodológicas e desafios para a pesquisa. Campinas, SP: 
Autores Associados, 2005, p.03-30.

. Mapas de freqüência a escolas de primeiras letras. Revista Brasileira de História da Educação, Campinas, n.17, p.41-67, maio-agosto/2008.

WISSENBACH, Maria Cristina Cortez. Da escravidão à liberdade: dimensões de uma privacidade possivel. In: SEVCENKO, Nicolau (org.). História da vida privada no Brasil 3 - República: da Belle Époque à Era do Rádio. São Paulo: Companhia das Letras, 2006, p.49-130.

ZALUAR, Augusto-Emílio. Peregrinação pela Província de S. Paulo (1860-1861). São Paulo: Livraria Martins Editora, 1953.

ZOTTI, Solange Aparecida. Sociedade, educação e currículo no Brasil: dos jesuítas aos anos de 1980. Campinas, SP: Autores Associados; Brasília, DF: Editora Plano, 2004.

Website:

Número de estrangeiros que entraram no Estado de São Paulo (1885-1929). Disponível em: $<$ http://www.memorialdoimigrante.org.br>. Acesso em: 09 de junho de 2009.

Número de estrangeiros residentes na cidade de São Paulo (1872-2000). Disponível em: $<$ http://www.memorialdoimigrante.org.br>. Acesso em: 09 de junho de 2009.

Índices de crescimento demográfico na Capital, no Estado de São Paulo e no Brasil. Disponível em: $<\mathrm{http}: / / w w w . m e m o r i a l d o i m i g r a n t e . o r g . b r>$. Acesso em: 09 de junho de 2009.

História das escolas públicas paulistas. Disponível em: $<$ http://www.crmariocovas.sp.gov.br $>$. Acesso em: 27 de novembro de 2009. 
ANEXOS 